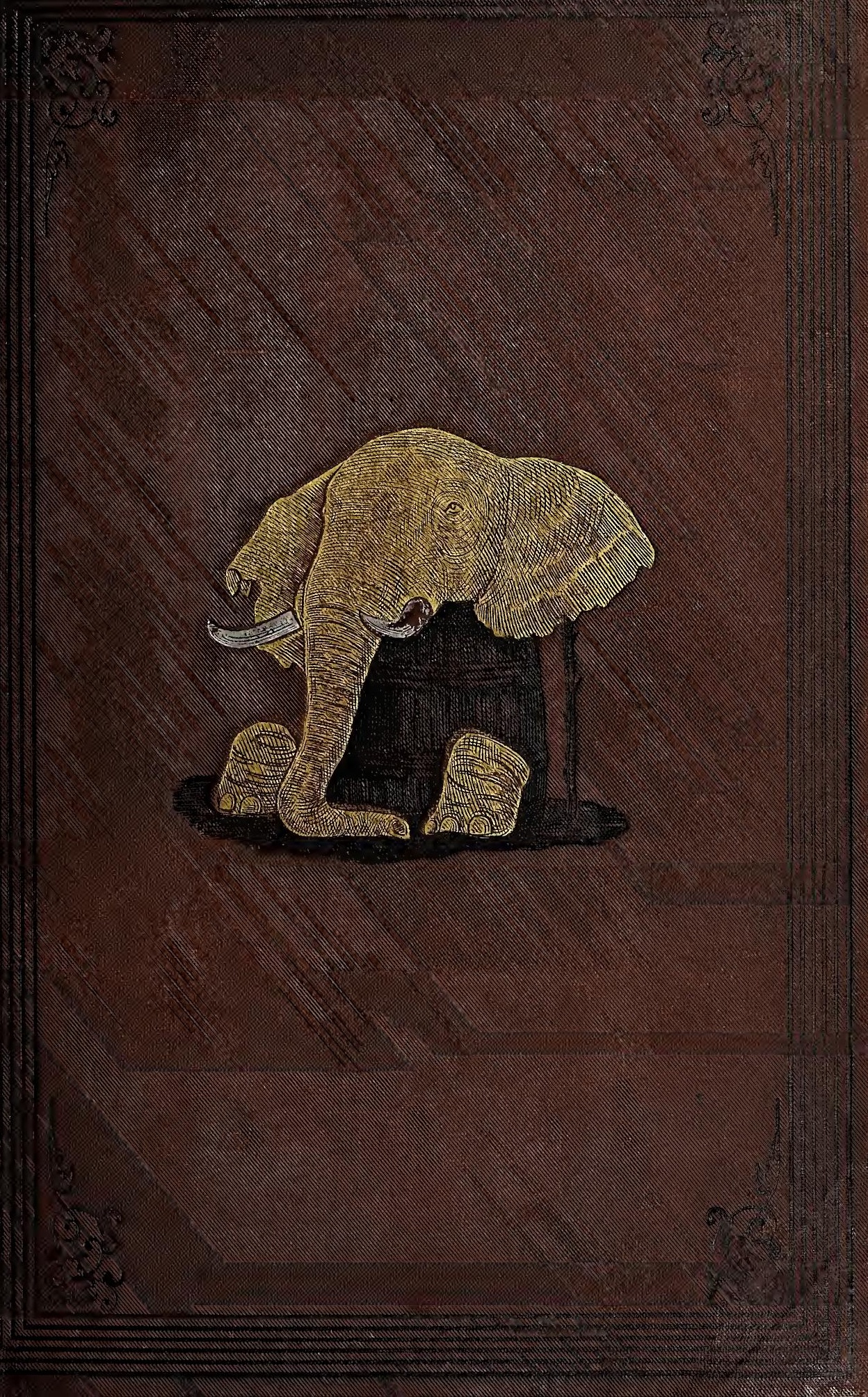




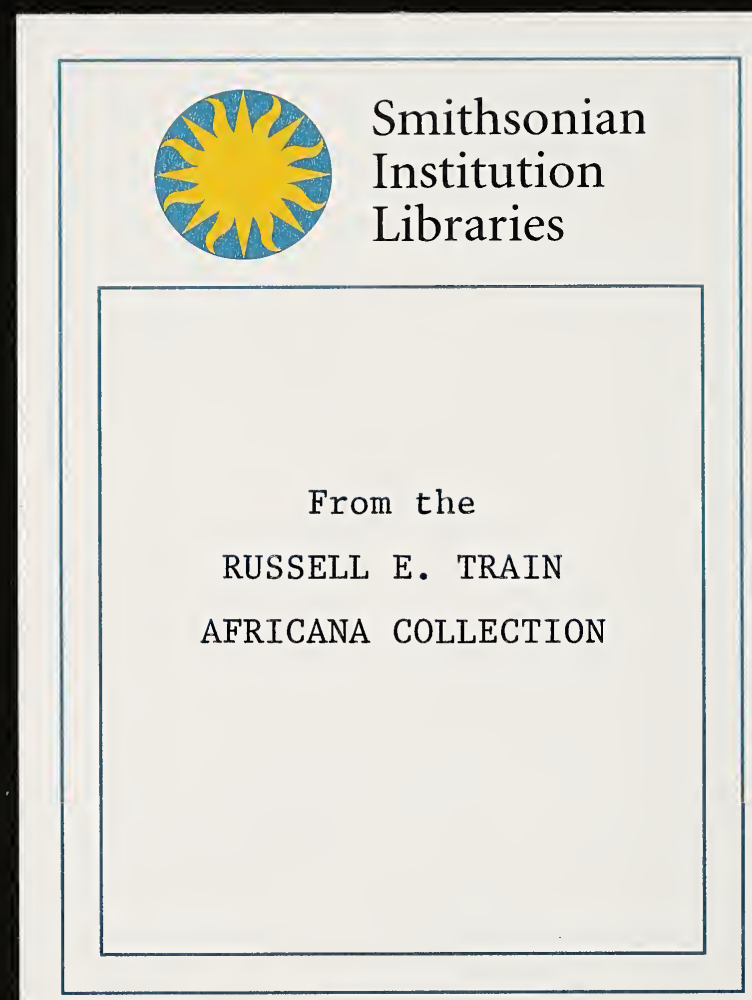



$R^{33^{\circ}}$ 


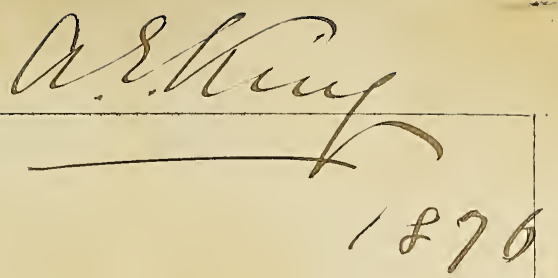

Ofreana

FIGHTING AND HUNTING IN SOUTH AFRICA 
LONDON : PRINTED BY

SPOTLISWOODE AND CO., NEW-8TREFT SQUARE AND PARLIAMENT STENT 
- 


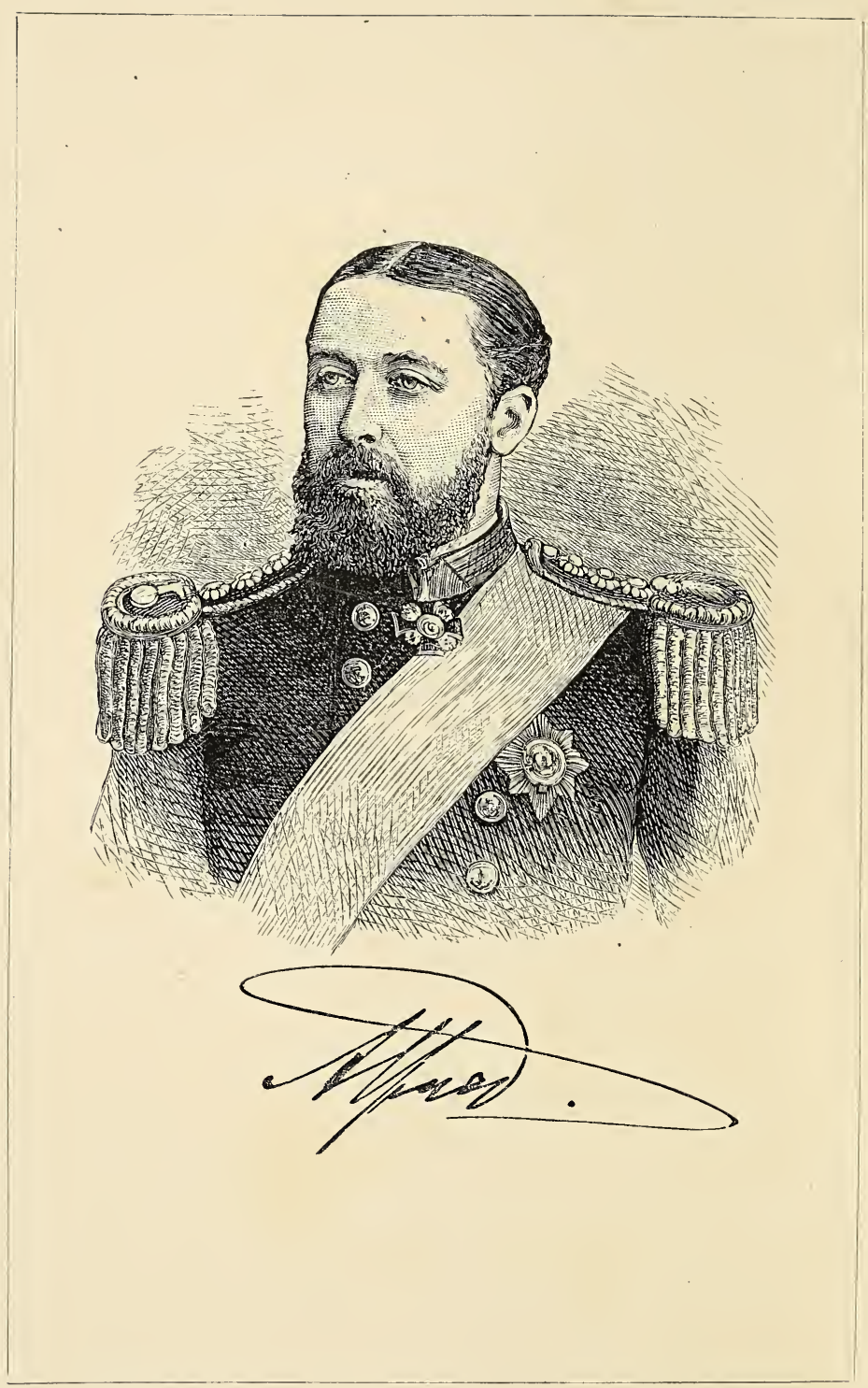

Frontisplece. 


\section{SPORT AND WAR}

OR .

RECOLLECTIONS OF FIGHTING AND HUNTING IN SOUTH AFRICA FROM THE YEARS 1834 TO 1867

WITH A NARRATIVE OF

H.R.H. THE DUKE OF EDINBURGH'S VISIT TO THE CAPE

By MAJOR-GENERAL BISSET, C.B.

geditly attap and alllustrations

LONDON

JOHN MURRAY, ALBEMARLE STREET 1875 



\section{$D T$ \\ 1732 \\ .1357 \\ 1875 \\ SCNHRB}

HIS ROYAL HIGHNESS ALFRED ERNEST ALBERT

\section{DUKE OF EDINBURGH,}

K.G., K.T., \&c.

THESE SKETCHES OF ADVENTURES IN THE FIELD AND RUSH

IN SOME OF WHICH HIS ROYAL HIGHNESS

TOOK A PROMINENT PART

ARE WITH HIS PERMISSION RESPECTFULLY DEDICATED

BY THE AUTHOR 



\section{PREFACE.}

My REason for laying before the English public my 'Recollections' of some of the events that have occurred to me during many years' residence in South Africa is, that I believe the subjects treated of in this little book are such as have a permanent interest with many readers.

Narratives of field sports, when accompanied by danger and privations, will always be interesting, and find a responsive echo in the breasts of Englishmen, who always show their love of true sport, in England, by their keenness in pursuit, if not in the magnitude and multitude of the game pursued.

The records of wars carried on by Englishmen against so dangerous and formidable an enemy as the Kafirs have so often shown themselves to be, can never be ' too late,' or fail to command that interest insepa- 
rable, in the minds of brave men, from deeds of daring and danger.

Sincerely do I hope that these records of Kafir wars may prove to be 'tales of the past ;' but there are not altogether wanting some grounds for apprehension that recent events, in and about Natal, may lead to a renewal of hostilities with the natives of South Africa.

Should such prove to be the case-which may a good Providence avert-my recollections of the ways and designs of Kafirs, in previous wars in Kafirland, may perhaps be of service to those engaged, or at least tend to increase the interest felt for our soldiers engaged in cruel and dangerous conflict with such fierce and savage foes as Kafir warriors have hitherto proved themselves to be. 


\title{
CONTENTS.
}

\section{CHAPTER I.}

\author{
MY FIRST PATROL-1834.
}

Kafir War, 1834-5-Kafirs enter Lower Albany-Cowie Bush-Attack -A Race-Wounded-Paddy McGrath . . . PAGE 1

CHAPTER II.

MY SECOND PATROL-1835.

Frontier Posts-Waggon Escort-Kafir Commando-Attack-Retreat - Jenkins killed-Kafir Drift Post-Waai Plaats-Kafirs driving Cattle - Awkward Predicament - Abandoned Post - Christmas

Dinner . . . . . . . . . • • 4

\section{CHAPTER III.}

ENO'S BRAVE DAUGHTER.

Kafir War, 1834-5-Expedition into Kafirland-Committy's DriftFlooded River - The Auctioneer - Breakfast Vley-The Chief's Kraal-A Brave Princess-Primitive Dress-Life for a Life-Fort Wiltshire - The Gaika Tribes-Tyalie and Macrmo - BiltongBurning Kraals-Chumie Post-Hotch-potch . . 8 


\section{CHAPTER IV.}

MURRAY'S KRANTZ.

Kafir War, 1835-Amatola Mountains-Mount Kemp-Attack on Murray's Krantz-Sir Harry Smith-Louis Arnoldus-Storming the Rock-Murray wounded-O'Toole-22,000 head of CattleCourt-martial-Humane Governor. . . . . PAGE 14

\section{CHAPTER V. \\ THE DEATH OF HINTZA.}

Advance over Kie River-Flying Column-Captured Cattle-Riding Pack-oxen-The Chief Hintza surrenders-Barbarous manner of killing $\mathrm{Ox}-\mathrm{A}$ Witch Doctor-The Fingoes-Their Origin-Liberation from Bondage-Kafir Atrocities-Hintza a Prisoner-Proclamation-British Kaffraria-100,000 head of Cattle-Hostages-Renewal of Hostilities-Patrol-Forced Marches-Subterfuge-The Guides - Witcheraft - Charms-Piet Uys's Horse - Escape - A Death-race - Bashee and Umtata River - Death of Major White

\section{CHAPTER VI. \\ THE HIGHLAND MAJOR.}

Province of Queen Adelaide-Outposts-Fort Beresford-Highlanders' Bush Party-Night Attack-False Alarm-Baboons-Reinforced -The Major missing - Old Charger-Queer Position - Vicious Horse-Very drunk-Bleeding to Death-Anecdote I.-Post on Fire-Powder Magazine in Danger-The Major's Coolness-Anecdote II.-Province of Queen Adelaide abandoned-Lord Glenelg-Firegrate-The coolest Place in the House-Anecdote III.-Committy's Post - Field Officer-Present Arms-A fine Figure--Anecdote IV.-Stables-Young England-Chanticleer-Um, 'gad, took the

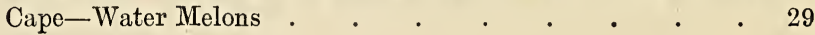




\section{CHAPTER VII.}

THE WITCH-DOCTOR.

Fort White, 1834-5-Revolting Sight-A Kafir Bewitched-A She Devil - Exorcisms - Diabolical Proceedings-Reptiles extracted from living Man-Fantastic Gyrations-A Grasshopper-A Blackbeetle- 'Marwhow'-The Vampire-A Lizard-Bewitching Matter -A Cure-Payment-Revelation-Rheumatism . . PAGE 40

\section{CHAPTER VIII.}

MY FIRST LION HUNT-1839.

Shooting Expedition-An Orderly's Horse-Didema Mountain-John Crause-Primitive Officer-Dederick Putter-A Bone Target-A Mist-Seven Lions-Gullies-Lions at bay-Mode of shootingGood Shots-Skeet Englishman-Four Lions killed-Tent Carpet -Lion-hearted Soldier . . . . . . . 46

\section{CHAPTER IX.}

\section{WAR OF THE AXE-1846-?.}

Cause of War-Rescue of Kafir Prisoners-Murder and MutilationPalaver - Intended Treachery-War declared-Sir B. D'UrbanBurns Hill Mission Station-Sandilli's Kraal-C'olumns of AttackEnemy's Position-Fighting in Amatola Mountains-Guns in Position--Kafirs disappear-Captured Cattle-Lieut. Stokes' Express -Attack at Burns Hill-Captain Bambric killed-Steadiness of Troops-Camp on the move attacked-Loss of Baggage-wagonsHard Fighting-Defence of Ammunition-wagons-'Limber-wagon abandoned - Night Attack-Gallantry of Lieut. Boyce-Prisoner burnt alire - Move on Block Drift-General Attack - Corporal Telemacus's Bravery-Captain Sandes and Orderly killed-General Action-Bush-fighting . . . . . . . . 53 


\section{CHAPTER $\mathrm{X}$.}

AFFAIR IN THE COWIE BUSH.

Kafirs overrun the Colony-Troops return to follow-up-Lower Albany Bush-fighting-Brave Joe Salis-Recall-Volunteers to the FrontCentre of Threes-Panic of the Enemy-Slaughter-Hide and Seek -A Stack of Ball-dresses (Robes)-A Tottie's Nous-A RiddleKafir Plums-Defeat of Kafirs . . . . . PAgE 70

\section{CHAPTER XI.}

\section{PASSAGE OF THE FISH RIVER.}

Relief of Fort Paddie-Fish River-Committy's Hill-Bush-fightingRocky Position -Narrow Escape-Major Gibson engaged-Charger shot - Wagon Encumbrances - Renewed Bush-fight - Cavalry supports on Foot-Captain Walpole, R.E.-How to move dead Oxen -Bound and Rebound-Wounded-Peddie relieved . . 78

\section{CHAPTER XII.}

\section{BATTLE OF THE GUANGA.}

Beginning of Wars-Powerful Chiefs-Council of War-Seyolo and Umhala (Brave Man and Wild Cat)-Consequences-Spoor-Native Repast-Bad Powder-Kafir Fighting-Long Shots-A 'Bob' or a 'Thud '-Major Walpole-Colonel Donoran's Rush-Chief Zeto killed-Dispersion-Recall-Nine hours' Work-Guanga RiverA Buck-jumper-Runaway Horse-Squaring the Circle-What met my Sight_' Ogh!' 'Marwoh !' 'Hurrah!'-Formation-Trot-Grand Sight-Guns open-Charge-The Result-7th Dragoon GuardsCape Mounted Rifles-Walpole-Panic, Rout, Flight-SlaughterTwo to one-Narrow Escape- Prisoners - Fingoe-'Targho'Struggle for Life-Blood and Water-Captain of Free Troop-Extenuating Circumstances-Express to Head-quarters--Fight over the Fire-Marwoh 


\section{CHAPTER XIII.}

MURDER OF FIVE OFFICERS AT THE SOHOTA MOUNTAIN.

Sohota Mountain-Kie River-Night March-Intricate Defile-Minute Guns - Vultures - Dead Officers - Decapitation - Witcheraft Column of Attack-Fighting-Five Officers killed-Major BakerBurial Service-Three other Officers killed-Fire to protect a Grave • . . . . . . . . . . PAGE 99

\section{CHAPTER XIV.}

THE AFFAIR OF THE GOOLAH HEIGHTS.

British Kaffraria-Buffalo Line-Ambush-Mule Wagons-AttackSir Walter Currio-Commandant Muller-Three Farmers killedKafir Superstition-Muller's Bush-Corroded Caps-A SkirmishMouse in a Calabash-John Crouch-Adrance-Good PositionShot for Shot-Mule Waggon-drivers-Sister Anne in Bluebeard - Cape Mounted Rifle Race-Charge on Foot-Dead KafirsFlight

\section{CHAPTER XV.}

THE BEEKA MOUTH.

Waterloo Bay--Drought-Cattle Guard killed-Alarm-Sir P. Maitland-Body Guard-Pursuit of Enemy-Heary Beach-Pumped Horses-Enemy in view-Chaso-Beeka River-Charge-Right and Left-'Set at Ease'-Re-capture Cattle-Kafir Shots-' Ping' -A Plate-chest-Return to Camp . . . . . 116

\section{CHAPTER XVI.}

THE SURRENDER OF SANDILLI.

Sir George Buller's Division-Sandilli's Surrender-' Personlyk lieve' -Xo-xo-Sir George Berkeley-A long Ride-The prisoner Chief 


\section{CHAPTER XVII.}

THE BOOMAH PASS- 1850.

Kafir War, 1850-1, 2, 3-British Kaffraria-Military Head-quartersKing William's Town-Katir Chiefs-Hostile Indications-Colonel Mackinnon-Hisjust Rule-Medes and Persians--Sir Harry Smith - Kafir Commissioners-Tzlambie and Gaika Tribes-March of Troops to Fort Cox-Demands-Arrival of Governor-Sandilli deposed-Brownlee Regent-Clanship of Kafirs-Amatola Mountains - Columns of Troops-Colonel Eyre to Kaboosie-Colonel Mackin.non to Keiskama Hoek-Route of March-Halt for BreakfastMasses of Kafirs-A Spy-March continued-Wolf River-Description of Boomah Pass-Troops enter Defile-Order of MarchKafir Police and Cape Mounted Rifles-Attack in the Pass-Return to Command-Orderly's Advice-The Result-Wounded-Impulsive Utterances-Infantry Column-Dr. Stewart-Bush-fightingReach the Open-Dr. Fraser-Grand fine Fellow-Medical Panniers -Leaving the Wounded-Brains-Capt. Catty wounded-Kafir Police outflanking-Killed and Wounded-Advance to Kuiskama Hoek-A Night Camp-Mode of carrying Wounded-Rer. Mr. Nevins' Station-Lucky Escape-Station burnt-Life saved-A brave Kafir Woman-Rev. Togo Sago-Christmas Day, 1850-The March-Masses of Kafirs-Quilli-Quilli Mountain-AmbushAttack-Advance-Narrow Eseape-Sergeant Extein-Old Brown Bess-Halt under Arms-Advance-Charge-Bailie's Grave-A fine Fellow-'Taban Doda-Kometje Flats-Debe Neek-Horrible Spectacle-Mutilations-Witch Doctors-Incantations-Fort White -Reinforcements-Night March-Captain Mansergh-Post attacked-Rebel Serjeant-Kafir Police in Arms against us-Settlers' Refuge-Cool Soldier-'Steady, Boys, steady'-Columns advanceA Volley-Continuous Fire-Chiefs killed-Confusion-Retreat-A British Cheer-Day and Night Attacks-Half Rations-Fort Cox besieged-Mrs. James - What a Lady will do-A Turkey-The Egg of Life-Secondary Hæmorrhage-Despatches-Equibeka Mission Station-A Missionary Court-martial-Station burnt-The Ladies -Fighting at Fort Hare-Major Somerset-Military Villages Chumie Hoek-Troops arrive--The Siege raised-Home . PAGE 128 


\section{CHAPTER XVIII.}

THE HONEY-BIRD.

A wonderful Bird-Instinct-Showing a Bee's Nest-Wild HoneyHow to find and take a Nest-Death's-head Moth-Native Superstition-Thunder with a 'Burr'-British Officers put to FlightNimble Totties-The Doctor-A Sting-Head over Heels-Dutch Bcers' Belief-Reasoning-The Rattle-Animal Instinct-Bird Wisdom-Taking the Honey . . . . . PAGE 160

\section{CHAPTER XIX.}

\section{LOCUSTS AND WILD HONEY.}

Theories-The Locust Tree-The African Locust-The Plague of Egypt-Food for Man and Beast-John the Baptist-Locust Eggs -Larvæ-Foot Soldiers-Native Mode of Killing and CuringLocust Flour-Locust Bread and Honey-Locust-birds . 168

\section{CHAPTER XX.}

THE WATER SPIRIT, A LEGEND OF SOUTH AERICA.

Native Superstition-Cape Rivers-A Siesta disturbed-The Koonap River-Hottentot Venuses-The Spirit walking on the WaterBeauties bathing-Alarm-Elsie-The Run Home-OstrichesWrestling with the Spirit-A Rescue-Awkward Predicament-The possessed one-A Sacrifice-Propitiation-Atonement-The sprinkling of Blood-Acceptation-Elsie's Recorery-Typical Superstition -Faith-Under the Water . . . . . . . 174

\section{CHAPTER XXI.}

THE GRAND BATTUE, OR ROYAL SPORT IN SOUTH AFRICA.

Cape of Good Hope, July 1860-Arrival of H.M.S. 'Euryalus'A Royal Midshipman-Great Rejoicings-Simon's Bay-Port Elizabeth-Birthday Ball-Departure-Leave-taking-Amsterdam Flats-A Hunt-Sympathy-Sundays River-Sir Walter Currie 
-Nazaar-Graham's Town - The Settlers' Home-Rejoicings Demonstrations of Loyalty-English Hurrahs-Hottentots and Fingoes-Parades, Banners, and Bright Eyes-Another Ball - Oatlands - The young Oak-treo-Port Alfred-Start for Beaufort-Heald Town Mission Station-Alice-The Chief Kama--Amabella-Debe Neek-King William's Town-Colonel Maclean Chief Commissioner-Presentations-Parades-German Military Settlers - Stutterheim - Sandilli presented - Thomas River-Kafir Group-Mounted Burghers-Tambookees-Rebel Hottentots-Royal Clemency - Queen's Town - Demonstrations of Loyalty-Hanglip Mission Station-National Hymn-Sneuw Berg - Burgher's Dorp - Aliwal North - Currie - Mosheish Natives-Austin's Reserve-Boundary of the Colony-Our TrekOrange River - Free State-Smithfield-A 'Trippler'-Camp outOur Fire-Game-Good Shooting-Bloom Fountain-Royal Salute - Special Commissioner--English Folly-The Chief Morocco-Mr. Baines-The grand Battue-A Lion at fault-Masses of GameWhirling-Stampede-Slaughter-600 head killed-Pack-oxenDried Meat-Trophies-Ostrich Farming-A novel IncubatorFeathers-More Shooting - Wynberg-Cordiality of ReceptionPresident Pretorius-The Meeting-Our Prince-A Royal Present -More Sport-A good Shot-Wounded Gnus- 'Greek meets Greek' -A fine Trophy-How we got along-Sentry go-Our Out-span'Carabenatje'-Stampede of Game-Harrismith-Forage-Dragonsberg Mountain-Natal-Camp Fire-A Storm-The ResultLangalibalele - Colenso - Bushman's River - Umgeni Falls Neptune's Arch-Pietermauritzberg-Shepstone-Zulu War-dance -War Songs-Sham Fight-Prophetesses-Native Salute_'Biatt!' —Striking Effect-Loyal Demonstrations-The Ball-My Highness -Durban-1,500 Miles-Re-embark-Voyage to Cape Town-Rock astern-Currie and the Lubber's Hole-Free of the Ship-Goodbye.

- PAGE 180

\section{CHAPTER XXII.}

\section{A LION HUNT: NA'TAL- 1865.}

Basuto Inroad-Fort Buckingham-Tugela River-Tiger Hunt-A Man killed-Trek to Newcastle-A Lion Skin-Shooting large Game-Dutch Burghers-Our Camp-The Ladies-Lion HuntOne shot-A wounded Lion-Breaking Cover-Captain of the 
Hunt-Advance-The Lair-Gevaarlyk-Be ready-Flying Shots -Death-A Cheer-Poor Beast-Superstition-Lion-heartedJackals

PAGE 215

\section{CHAPTER XXIII.}

\section{THE ELEPHANT HUNT, OR ROYAL SPORT IN SOUTH AFRICA-1867.}

H.M.S. Galatea-The Duke of Edinburgh's Arrival at the Cape-A Run to Cape Town-The Post Cart-Van Starden's River-An Escape -Gamtoos River-An Upset-A Sore Head-Humans Dorp-A Crooked River-Long Kloof-Cradock's Pass-Fourteen Miles an Hour-George-A Perch-Mussel Bay-Biltong-Gauritz RiverRiversdale-Swellendam-Caledon-An Adrenture-Cape TownCiril Service Ciuj-A Bath-A Ball-His Royal Highness-Hospitality of Cape Town-Further Instructions-A Dilemma-Hunting Party-Transhipped at Sea-Kynsna River (Port Rex)-A Colonial Welcome-The Cavalcade-Magnificent Forest--Elephant Indications-The Camp-Royal Energy-Native Hunters-Mr. RexSpying out the Elephants-Early Start-Good News-Seventeen Elephants-Picked Men-Glorious Sight-Rank Vegetation-Consultation- 'A Bird in the Hand' \&c.-A Proposition-Responsibility-The Dogs-Effect-Elephants form Square-Our PositionRight and left Shots-Wounded-The Dogs again-Rojal Pluck'Best leg foremost'-Danger-Elephant Charge-An IrishmanGrand Sight-Charging Dogs-A loud Trumpet-Detached Elephants-Pursuit-The Prince's first Shot-A Shell-A fearful Blast -Second Hit-A Volley-Wounded Elephants-Dogs beat-Dusk -Climb to Horses-Return to Camp-Dinner-Gale and RainNext Day-Currie and Hunters-Wounded Elephant-Pools of Blood-Staggering Condition-A long Day-Punctuality-Result of Gale-All rejoice-Breakfast, scrambled Eggs-"Through the Wood'-Rover Elephant-Selected Party-Stalk the ElephantDanger-Consultation-Taking up a Position-A Governor's Taunt -A Prince's Reply-The Circuit of the Forest-New Position-The After-rider-Breaking Corer-Skeet, skeet, Alamagtig baas, SkeetA Pale Tottie-Diverted Rage-The last Trump_Anxious Moments - Calm and Cool-Twenty Yards - Right and Left-SwerreCurrie the Brave-A dead Monster-Hurrah-A Nip-The Second Elephant-100 Shots to kill-Photographs-Dimensions of a Royal 
Elephant-Crossing the Bar-A Bump-The Emu Rock-Return to Simon's Bay - Elephants' Heads - The Ball - Memorial of Hunt

PAGE 222

\section{CHAPTER XXIV.}

SOUTH AFRICAN LEGENDS: THE MANE-HAIR JACKAL.

Pilot Fish to the Shark-Jackal to Lion-Animal Magnetism-Transmigration of Souls-Hottentots' Belief-The Tzhar-Communionship - 254

\section{CHAPTER XXV.}

SOUTH AFRICAN LEGENDS: THE ELEPHANT'S EYE.

A 'Beam in the Eye'-A wood Fire-A Tit-bit-A Poke-Hippopotamus Foot-Good Appotite . . . . . . 255

\section{CHAPTER XXVI.}

CONTINUATION OF SOUTH AFRICAN LEGENDS: THE WOODPECKER'S NEST.

The Woodpecker tapping-Tat-tat-The Nest-Charmed SticksMode of Discovery-Up Stream-Antidote-Bewitched-Flooded Rivers-Improvised Boats-A good Swimmer-Confidence 259

\section{CHAPTER XXVII.}

A DAY AMONGST THE GNUS.

Early Days at the Cape-Colesberg-Orange River Banks-Mine Host -Hartebeast Huts-Inside Room-A small Window-A bad Night -A fair Day's Sport-In the Veldt-Buffels Vley-A Hot LakeMrs. De Wet-Aliwal North-The Past, the Present, and the Future . 


\section{LIST OF ILLUS'TRATIONS}

From Original Sketches by Captain $\mathrm{H}$. K. WILson, late 85th Light Infantry, and G. Scantan, Esq., M.D., Surgeon-Major.

Portratt of H.R.H. the Duke of Edinburgh . . Frontispiece The Kafir Chief Eno . Eno's brate Daughter, a Kafir Princess $\quad$. $\quad$. $\quad$. 8 Novel Chargers . . . . . . . . . . . 19

Captured Cattle crossing the Kie River . . . . 22 Sir Harry Smith and the Chigf Hintza; a Race for life $\quad 25$

A Witch-ростоR . . . . . . . . . 40

A Strugale for Life

The Boomah PASS . . . . . . . . . . . 132

Landing at Port Elizabeth $\quad . \quad$. . . . . . 180

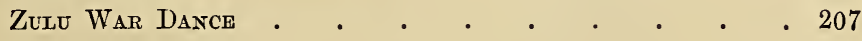

Zulu Men dancing $. \quad . \quad . \quad . \quad . \quad . \quad . \quad . \quad .214$

H.R.H. The Duke of Edinburgi and Party in Hunting

Costume . . . . . . . . . . . 231

The Charge . . . . . . . . . . . 246

The Elephant's Head $\quad . \quad$. $\quad . \quad$. . . . . . 250

MAP . . . . . . . . . . at the end 



\section{SPORT AND WAR.}

\section{CHAPTER I.}

MY FIRST PATROL-1834.

The KafIR WAR of $1834-5$ broke out a day or two before Christmas. Kafir wars generally do break out about that time of the year, because the crops are then standing and advancing towards maturity; and as the Kafirs carry no commissariat with them they are thus enabled to find food everywhere ; and another reason is, that the weather is then warm, the days long, and the nights short.

I was at the time but a boy of fifteen years old; nevertheless, as martial law was proclaimed, all civilians had to serve under arms, and I joined the Bathurst Volunteers, under Commandant Bowker. The Kafirs had already entered Lower Albany, in the colony, and a patrol was sent to warn the farmers and 
to give assistance where they could. The patrol consisted of about twenty civilians, of which I was one. We proceeded first to the Kereiga River; and on reaching Bothas Farm we saw the Dutch mothers snatching up their children and running in all directions. This was occasioned by some native leaders and drivers of wagons having run home from the 'Cowie Bush,' a distance of six or seven miles, reporting that their masters were attacked and surrounded by Kafirs. They had left the farm that morning with two oxwagons to fetch 'thatch' (rushes), and while returning from the Cowie River were attacked by the Kafirs. The native servants fled, and the three Dutchmen were surrounded and left to fight it out; two only of them had guns. They retired, but when out of the main bush had to take 'cover' in a small round clump of bush in the open. This small bush was surrounded by the Kafirs, who were afraid to enter, but kept throwing their 'assaigais' (or spears) into it. The Dutchmen loaded and fired as rapidly as they could, and we could hear this firing at a great distance, and raced as fast as our horses could carry us to their assistance. On our approach the Kafirs fled into the forest, and we found two of the Dutchmen in a most exhausted and deplorable condition-one had nineteen and the other twenty-three wounds; and, strange to say, the man without the gun was untouched. 
There was no doctor with our party, so Paddy McGrath, the farrier, had to attend to the wounded. One poor fellow had a bad spear-wound in the stomach, through which a portion of the entrails were protruding; and I had to hold this wound open while McGrath put back what was outside. It was a nasty beginning of war, and three men actually fainted from the sight---no, I am glad to say they were not men, but only threeninths of the species, as one was a tailor, and the other two were his apprentices. McGrath was sufficiently a doctor to know that the wounded man could not live, for he found one of the intestines cut in two. The poor fellow died within a few days afterwards, while the one with twenty-three wounds recovered. It was impossible to follow up the Kafirs into the forest, so we returned with the wounded to the farm and escorted the whole family into Graham's Town, as a place of safety. 


\section{CHAPTER II. \\ MY SECOND PATROL- 1835.}

When the war broke ont there were several outposts, or advanced military positions, on the frontier, viz. Kafir Drift post, on the right bank of the Fish River, near the sea; Fort Wiltshire, on the right bank of the Keiskama River, in the then so called Neutral Territory; Fort Beaufort, on the Kat River; and the Chumie post, or Fort Warden, on the upper branches of the same river, on the extreme left, with one post of communication in the rear of this line, called Hermane's Kraal, afterwards Fort Brown. These posts did not hold sufficiently strong garrisons, nor were they provisioned as they ought to have been, and it was deemed expedient to abandon them. With this view a convoy of some dozen wagons was despatched from Grabam's Town, under an escort of only twelve volunteers, to Kafir Drift post to withdraw that detachment. I could name all this escort, but it is enough for my purpose to say that I was one of them, and we were under the com- 
mand of Lieut. Brummell, 75th Regiment. The wagons and escort had proceeded as far as Cadel's Hill, near the 'Cheshire Cheese,' when we saw to our right, on the outskirts of the Cowie Forest, what we thought to be a strong commando of farmers; they, however, turned out to be Kafirs, dressed in European clothes plundered from the homesteads they had burnt. This force immediately came on to attack us; and as the wagons were scattered and in a long line, there was no defending them; the escort could only, therefore, cover the retreat of the wagon-drivers and leaders, and the wagons and oxen were captured by the enemy. One Englishman, named Jenkins, who would not abandon his wagon, was killed by the Kafirs.

The next day a strong patrol was sent down without wagons to reinfurce Kafir Drift post, and while en route near 'Waai Plaats' (Windy Flat) we saw numbers of Kafirs driving herds of cattle from the colony towards Kafirland. They were at the time crossing the Kap River, and ascending the steep hills on the other side, atter passing which they would still have an open country to go over, between the Kap River Bush and the Coombs Bush, adjoining the Fish River. The patrol made chase after these Kafirs and cattle; it was a regular ' hurry-skurry;' and the long run, added to the steep hill on the other side, took so much out of the horses that mine ' knocked up' on the flat midway 
between the Kap and Coombs Bush. It was a regular case of 'Devil take the hindmost,' and I was left to shift for myself. The Kafirs left in the Kap River Bush were still streaming across this open, not knowing that any of the patrol were there, and several of them with assaigais passed within a few yards of me. I was enabled to keep them off by pointing my gun at them, but had I fired at any one of them the Kafir with his bundle of seven assaigais would have had the advantage before I could re-load. The scattered patrol, however soon returned from the Coombs Bush unsuccessful; and as one of them (Mr. Carter) had a spare horse it was given to me, and the patrol proceeded on to Kafir Drift post, which we reached just as it was getting dark.

This patrol was sent down to reinforce the post. The post was there, but the troops were gone-the officer commanding had fallen back the day before on Bathurst. Very little transport had been available for this service, and I am sorry to say there must have been some degree of panic, for on our arrival at the post on the evening of Christmas Day we found dinner and all sorts of good things prepared; the larder was full of good beef, turkeys, fowls, \&c.; in the pantries were ready-made puddings, and wine actually cooling in the cellars, besides which the 'yards' were full of poultry of all descriptions, and there was plenty of 
forage for our horses. As may readily be supposed, the patrol revelled that night upon ' good things.' The next day we patrolled the country, and returned vi $\hat{a}$ Bathurst to Graham's Town. 

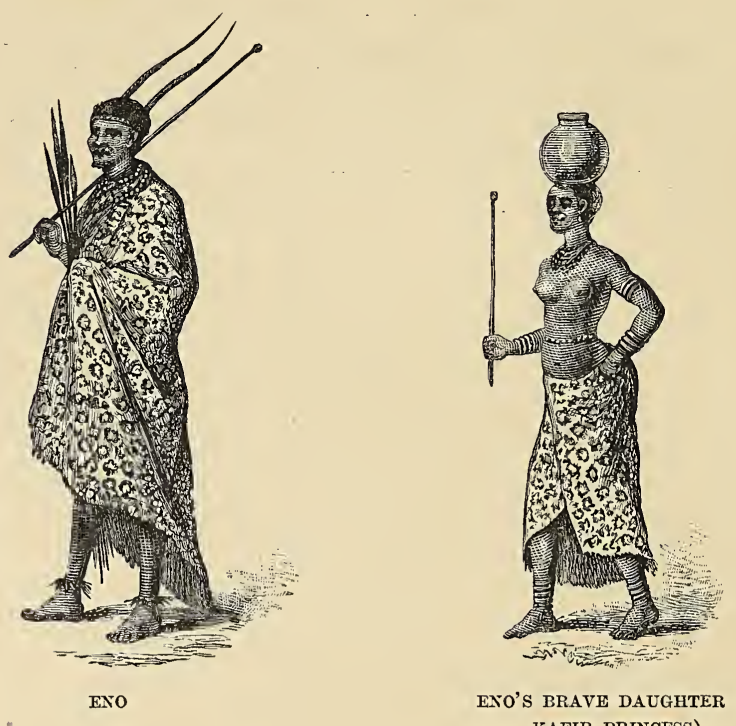

ENO'S BRAVE DAUGHTER (A KAFIR PRINCESS)

\section{CHAPTER III.}

ENO'S BRAVE DAUGHTER.

Soon after the outbreak of the Kafir War of 1834-5, and while the whole of the colony was overrun by the savage marauders, an expedition was hurriedly got up to enter Kafirland, and so divert the enemy back from the colony to their own country, in order to protect their own cattle. Major Cox was appointed to command this expedition, and the force consisted of a few regulars (Cape Mounted Riflemen), but chiefly of volunteer 
forces; Dutch and English farmers, and some of the Graham's Town inhabitants. We started with three days' rations, expecting to be able to capture and live upon the cattle of the enemy. A good deal of secrecy was maintained as to our destination. Major Gregory and Lieutenant Granet, two officers of the 98th Regiment, who were on the Frontier shooting when the war broke out, also volunteered, and commanded some of the irregulars. We marched from Graham's Town in the afternoon, and reached Commetty's Drift, on the Fish River, just at dark. It was noticed that the river was turbulent and rising, and it would have been wise to have crossed at once; as it waș we halted (but were not allowed to make fires) until three o'clock next morning, when the column (all mounted men) began to cross the river, which had been rising during the night; and the ford or drift was now so deep that many horses had to swim. This brings the following anecdote to my mind :-One of the volunteers from Graham's Town was a celebrated auctioneer, a plucky little fellow, but of so light a weight that he was being washed off his horse's back while crossing the river. Immediately below him, in the ford, was a great big fellow of the name of 'Tom Bailie.' The little man had already left his saddle; and as he was gliding by degrees towards his horse's tail his auctioneering parlance came to his aid, for you heard 'Going, going, gone, by G-!' and 
with that he vanished from his horse; but as the stream was taking him down Bailie caught him by the collar of his coat and held him up by one hand, bringing him safe to shore. A few other men and horses were washed down the river, but there was no loss of life. We then marched on, and at daylight reached the top of Commetty's hill on the Breakfast Vley side, and captured a drove of horses that were being driven out from the colony into Kafirland. Passing on as rapidly as the long distance would admit of, we fell upon and attacked the kraals occupied by the people of the chief Eno in the valleys near and about Buck Kraal. Most of the 'warriors' had gone into the colony ; enough, however, had remained behind to make a tolerable skirmish of it, but the men soon 'skedaddled' into the bush. I now come to that part of my story in which I wish to commemorate the devoted conduct of a brave girl, the daughter of the chief Eno. This chief was too old to take the field himself, and had remained with the few warriors left to protect the women and cattle. The troops coming so suddenly on his village, there was no chance of his escape except in the disguise of a woman; and his daughter seeing this, insisted on her father changing robes with her, for they only possess and wear one garment each, although the woman's robe is at once distinguishable from the man's. On the approach of an enemy all savages, 
both men and women, fly from the villages, or kraals, and take shelter in the bush, and Eno thus escaped unscathed into the bush in his brave daughter's skin robe, who was shot in two places while 'drawing off' the fire from her father. I came up in time to save the poor girl's life, for she could not be induced to discover herself by putting aside the chief's tiger-skin kaross; and there were men present, smarting from the ruin of hearths and homes, who had no idea of taking prisoners.

After a halt and resting the horses the expedition retraced part of its route as far as Breakfast Vley, then continued up what was called the 'Neutral Territory,' and reached Fort Wiltshire, on the right bank of the Keiskama River. This was the largest and one of the strongest outposts on the Frontier, and was under the command of Major Halifax; but for some reason the troops had been withdrawn from it to Fort Beaufort. They had marched out a couple of days before we arrived, leaving everything exactly as it stood. The Kafirs had ransacked the place, but could not carry away the vast stores still remaining there. Furniture was smashed, doors and windows broken, spirit-casks stove in, featherbeds, \&c. that had been buried in the Commissariat corn stores ripped open, and the feathers all mixed with the grain, much to our annoyance, as our horses required forage. However, we soon found the way to remedy 
this by passing the grain through water, there being no wind in that hot valley. We halted here for two days, and then passed on to attack 'Charlie' and 'Macomo,' the two chiefs of the Gaika tribe at the Chumie; but we found all the villages deserted, the grain destroyed, and stock of all descriptions driven away; and as there was no breadstuff or provisions (except corn) at Fort Wiltshire, the English part of the expedition were becoming much famished from the want of food, for we had started with only three days' rations, and had now been out a week; and young troops are not overprovident at first.

It was here and on this occasion that we saw the utility of dried meat as a food for soldiers, or indeed for any man. The Dutch 'Burghers' invariably have a cross-bag, made of the prepared skin of a whole goat, which they carry by being tied by the middle over the crupper to the crupper staple of the saddle; this skin bag is filled on one side with ' moss-biscuit,' or very dry and light biscuit made from the finest flour, and mixed up with ' mosto,' or the unfermented juice of the grape. It makes a biscuit that will keep for ever, and is very nutritious. The other side is filled with what they call ' biltong,' or meat dried in the sun-it may be of beef or game. It is just sufficiently salted to prevent flies getting to it, and then thoroughly dried in the sun; so that a pound of beef is reduced almost to an 
ounce or a little more, with all the 'substance' and nutriment of a pound of meat in it. A mounted man may in this way carry ten days' food with him, without any commissariat train, and no incumbrance to protect. I saw Englishmen buying pieces of biltong from the Dutch about the size of your thumb for haif-a-crown, and it made a very good meal for the day.

After burning the kraals of the Gaika chiefs the expedition climbed the Chumie Heights; and at the Chumie post, old Fort Warden, we found a convoy of wagons with supplies, and Major Burney, of the Cape Mounted Rifles, with a strong force, which should have co-operated with us against the Gaikas, but had remained stationary on account of a slight inclemency of weather. It is said that Major Cox expressed his opinion of such conduct in pretty strong terms, for had we met any great opposition our force was not very strong. What I know is, that we revelled in good living that night and the whole of next day. This post was situated in one of the most fertile valleys of the Kat River, and all around it were splendid vegetable gardens. My mess borrowed an iron pot from one of the wagoners, and with the rations served out, supplemented by green-peas, beans, potatoes, cabbage, onions, herbs, \&c. fresh from the gardens, we made such a 'hotch-potch' that a spoon would almost stand upright in. 


\section{CHAPTER IV.}

\section{IIURAY'S KRAANTZ.}

Murray's KraAntz is the most eastern point of the Amatola Mountains, in British Kaffraria. It forms a peak of almost perpendicular rock, with abrupt precipices running back from it in two directions. From the peak itself a ridge runs down between two branches of the Buffalo River. The 'Gorges' of the Buffalo Poorts enter the mountains about three miles to the west of it; and Mount Kemp, the highest point in the range, is situated about six miles to the north-west.

There was considerable fighting in these mountains in the Kafir W'ar of 1835 ; and Murray's Kraantz takes its name from the storming of that rock by a force under Captain Murray, of the 72nd Highlanders, who was wounded on the occasion.

Sir Benjamin D'Urban was encamped, with the head-quarter division of troops, on the slopes below the mountain; and a combined force was detailed to attack the Kafirs in their mountain fastnesses at several points. A noted rebel Hottentot, named 'Louis Arnoldus,' was 
known to be defending this particular point, and Sir Harry Smith marched in command of a separate columr to attack this stronghold. The troops moved from camp before daylight, and Sir Harry at first intended to march round the east point of the bluff and attack it from the north side; but as we were marching over the ridge running down to the Buffalo River, a beacon-fire was lit at the bluff itself, and Sir Harry then decided to go at once to the attack. Daylight broke as we reached the edge of the rocky glen, and troops were at once sent in to the attack. It was a most difficult position to approach. Before reaching the solid cliff itself the troops had to pass between high masses of perpendicular rocks towering more than 100 feet above their heads on each side, with a passage not ten feet wide between them; this narrow passage serpentining round boulders and zigzagging round corners in the most extraordinary manner.

The Kafirs were quite prepared for us, for they commenced at once to throw down great rocks and spears, \&c. from the presipices above, which had evidently been collected there for the purpose. We, however, forced our way on until we came to the bluff or acute angle of the cliff itself; here only one man could pass at a time, and as that man came to the corner he was either shot down or assaigaied. I was at 
this time a volunteer in the Corps of Guides, under my oll friend Richard Southey, now Lieutenant-Governor of the Diamond Fields. Edward Driver was the particular guide on this occasion, and was himself wounded in the nose by an assaigai as he endeavoured to get round the corner. Captain Murray, 72nd Regiment, was wounded on the hip, and several men were killed and wounded. The first assaigai thrown wounded a man, and passed quivering into the ground not far from where I was standing. Walter Currie and myself stepped across to withdraw this assaigai, and as we drew it from the earth twenty spears entered the same spot as it came within the 'line of vision' from some hundreds of Kafirs who were in mass, but beyond the corner.

Sir H. Smith had in the meantime detached some companies of native battalions to pass round the northern extremity of the precipice, and thus outflank the Kafirs holding the point; but before they could accomplish the distance a plucky discharged soldier from the 75th Regiment, named O'Toole, had got into such a position at the point that he could fire round the corner as fast as the men could hand loaded muskets to him; and it was supposed that he was doing great execution, as we could see such an amount of the wooden shafts of assaigais, that it looked like a waving field of corn. We very soon heard the rattle of our own musketry 
on the other side of this body of Kafirs ; and they were taken so unawares by the outflanking party that they had very little chance of escape ; many, however, did get away by leaping and throwing themselves down the declivities of the rocks. Louis Arnoldus himself had got so jammed into the cleft of a rock that he could not extricate himself; and although his gun-a great elephant-gun, four to the pound-was shot to pieces, he himself was untouched, and he was taken prisoner in that helpless position. When the stronghold at the point was carried it appeared that O'Toole's zeal had been thrown away, as every ball had struck a rock in the line of fire immediately round the corner. A little farther on, where our men met those coming from the north, there was a good deal of slaughter, but the greater number escaped down the precipice, many of them no doubt being killed in the descent. The number of cattle on the plateau above was something: incredible. A little way to the west there was a cattletrack leading down to the Governor's camp, and a stream of cattle came pouring down this during the whole day. No less than 22,000 head of cattle were captured on this occasion.

Louis Arnoldus was tried by a court-martial and sentenced to death, but his life was spared by the humane Governor, Sir B. D'Urban. Captain Murray's wound was rather a bad spear-wound, and I have still 
got the assaigai which I withdrew from his body. There was a congratulatory ' general order' issued on the occasion; and after some more fighting in the mountains, the troops moved forward towards the Kie River. 


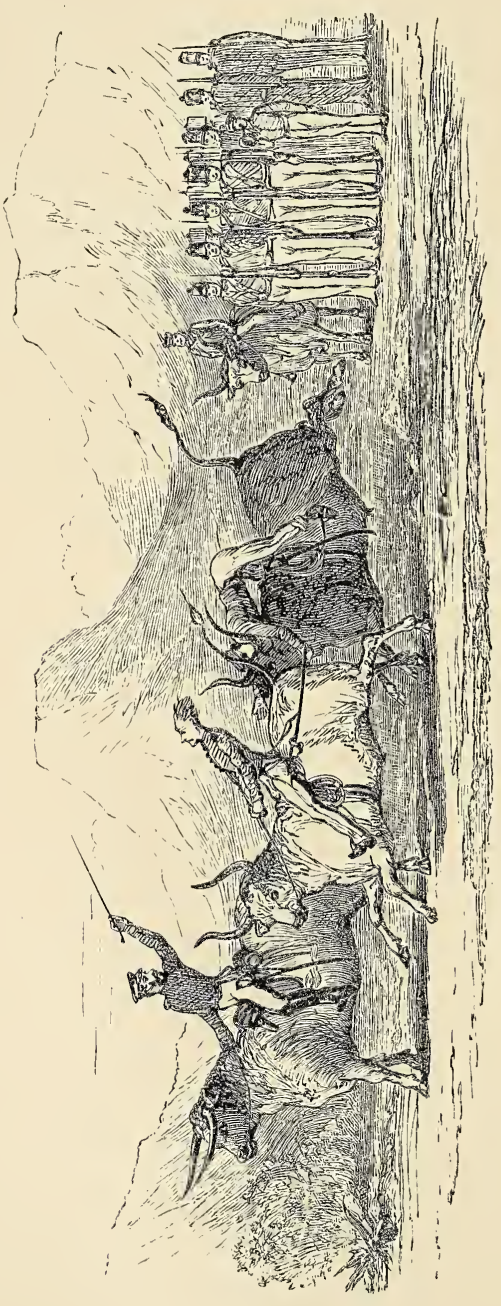

官 


\section{CHAPTER $V$. \\ THE DEATH OF HINTZA.}

DURING the war of the above period the troops under Sir Benjamin D'Urban crossed the Kie River, and carried the war into the Transkian Territory. The headquarters of the army halted at Butterworth, but a strong force under Sir Harry Smith moved up the left bank of the Kie towards the sources of the Tzomo River. This advance was performed by forced marches, and enabled the troops to overtake vast herds of cattle, which were thus captured from the enemy. A great many troop-horses ' knocked up' on this expedition, and were shot, to prevent their falling into the enemy's hands. The infantry officers' horses were in like manner destroyed; and it was curious to see officers riding at the head of their men on 'pack-bullocks,' guided by a thong through the ox's nose. Besides, the skin of a bullock is so loose on its body that it is difficult to keep either yourself or a saddle on its back.

The return into camp of this large patrol took nearly the whole day, from the long lines of cattle 
that had been captured and were being driven in. Head-quarter camp had followed us up from Butterworth, and we joined it at the Dabagas. The next day the paramount chief of all Kafirland, Hintza, surrendered himself to the Governor, and came into our camp, with a number of his head councillors and others. It is customary on these occasions to present the great chief with one or more head of cattle for immediate slaughter, according to the number of his retinue. On this occasion one only was presented; and the Kafirs' mode of killing it deserves to be recorded, as showing the savage nature of these men. The great ox was canght and pulled to the ground, while some of the menials were preparing a fire; the front and hind feet of the animal were tied together and stretched forwards and backwards by men pulling at them, the ox being turned and kept on his back. A Kafir 'wizard,' or doctor, as they are sometimes called, plunged his assaigai into the bullock's stomach, making the bole sufficiently large, on withdrawing the blade of the spear, to admit of a man's hand and arm. The fat, or covering of the inside, immediately protruded, and this was pulled out, cut off, and thrown over the blazing fire ; it frizzled up and became cooked almost instantly, and was then handed to the chief, who partook of it and handed portions to his head men. Not until this ceremony took place was the process of killing the ox 
continued. The 'witch-doctor' then plunged his arm into the hole, and the bullock was killed by the man dividing the heart-strings and blood-vessels with his hand. Such are the Kafirs in their savage life; and I am sorry to say I must detail a still more horrible scene that took place the next day, before I proceed to relate the circumstance attending the death of Hintza.

We had moved back towards Butterworth, and were encamped for the night, when an alarm arose that the Fingoes were attacked by the Kafirs. Now, the Fingoes had previously been serfs of the Kafirs, and were living in great numbers amongst them. They were originally the dispersed tribes from Natal, who had fled from the vengearice of Chaka and taken refuge amongst the Kafirs; and it having become known that Sir Benjamin D'Urban (the most humane Governor the Cape ever had) intended liberating these men from bondage, the Kafirs rose on them, and the barbarities committed were atrocious. Men and women were killed and mutilated, and the young women had their bosoms cut out. It is horrible to think of the barbarities that were perpetrated. The sight of these people flying from all directions into our camp was indeed most terrible to see.

During this time Hintza was a prisoner in our camp; and in order to protect the refugees and captured cattle the troops moved back to the Kie River, 
passing the liberated Fingoes and cattle over under escort en route to the Cape Colony. A proclamation was also issued declaring the country west of the Kie to be British territory (now British Kaffraria), and a royal salute of twenty-one guns was fired. This annexation more immediately affected the subordinate Kafir chiefs living between the colony and the Kie River, who thus became British subjects. The paramount chief, Hintza, had yet to be punished, and the Governor imposed on him a very heavy fine of cattle-I think it was 50,000 or 100,000 head. To this the chief at once agreed, but said he must himself go to collect them. This of course was not to be thought of, and Hintza said he would communicate with his people and have the cattle got together. After waiting for three weeks and no cattle making their appearance, the Governor determined to resume hostilities. Hintza then proposed that he should leave his son Kreilli, the present paramount chief of Kafirland, and his uncle Bookoo as hostages, and that he should accompany a small patrol into the heart of his country, where the cattle were being collected.

This arrangement was agreed to, and Sir Harry Smith was named to command the expedition. I was myself at this time (May 1835) a volunteer in the corps of Guides, and was appointed one of Sir Harry Smith's body-guard. I forget the exact number of troops 


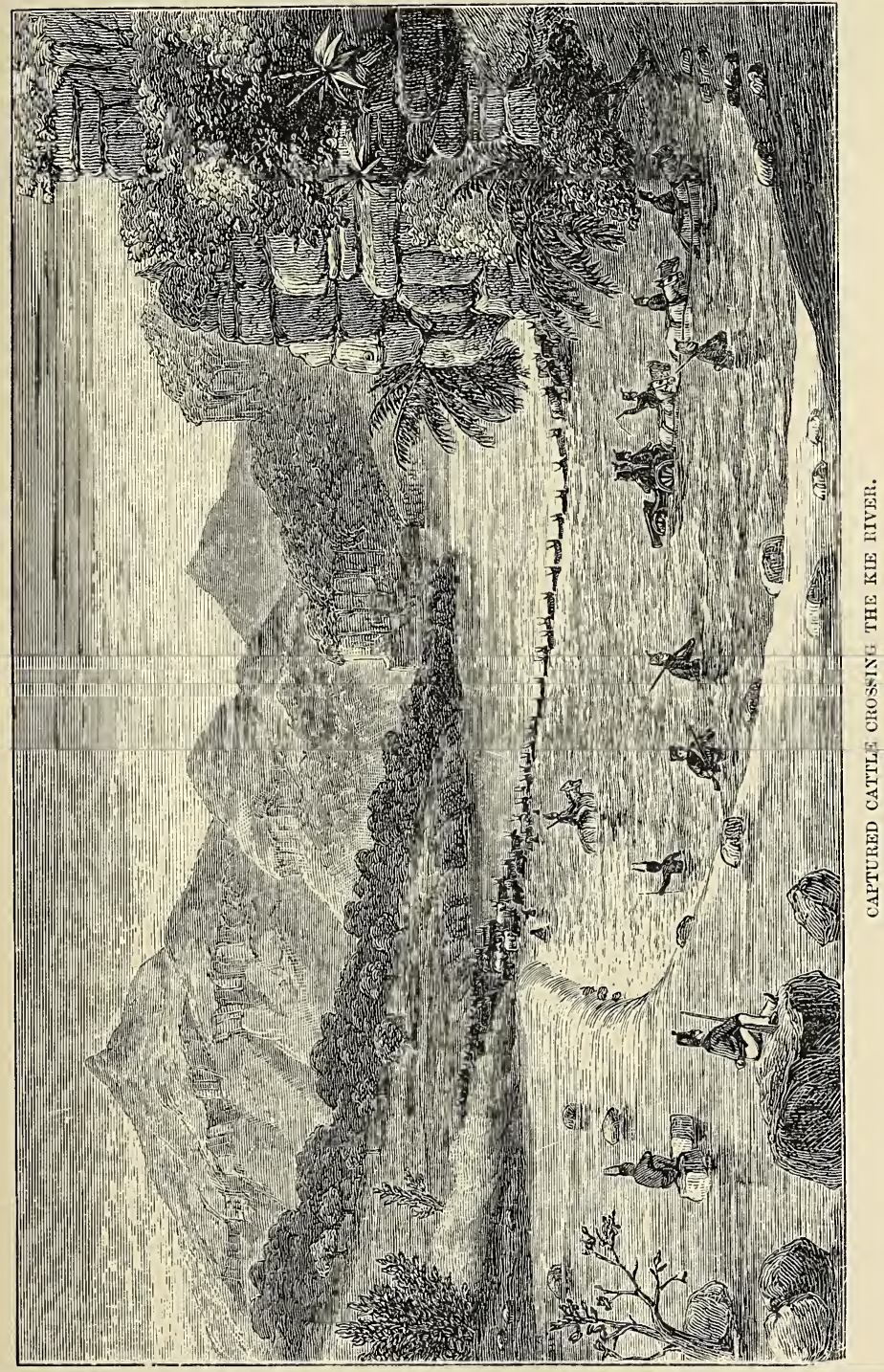



selected, but the party consisted of all arms except artillery. We moved from the head-quarter camp on the Kie by forced marches, leaving the knocked-up and footsore men in detachments in our rear, as supports or camps of communication. In one day and night the column marched fifty-two miles within the twenty-four hours. The third day, on approaching the Bashee River, we saw herds of cattle flying before us, but at great distances; and it became more and more evident that Hintza was using a subterfuge to draw our small body of men into the interior of his country with some ulterior object.

After marching all night the troops halted for breakfast in a valley under a ' table-topped' mountain. Hintza was always with Sir Harry Smith, a sort of prisoner at large, and in the particular charge of Captain Southey (now Lieut.-Governor of the Diamond Fields) and the corps of Guides, of which I was one. Hintza had now become very restless. Several messengers had been sent by him the day before to communicate with his people-some had already come and gone that morning-and his 'witch-doctor' was seen to tie a certain charm round his neck. Hintza used to ride his own horse, a splendid dark bay, a half-bred English horse, presented to him about a year before the war by Piet-Uys, a celebrated Dutchman, a great hunter and breeder of superior horses. The troops did not halt 
long, and on advancing had almost to scramble up the steep ascent of the mountain. Sir Harry Smith was in advance, as it were, leading the column, with Hintza at his side, followed by a few Cape Mounted Riflemen and the Guides. Hintza at one point pushed past Sir Harry, and the General had to restrain him; but nothing more was then thought of it, and soon after we reached the tableland on the top of the mountain.

A grand sight met our view. As far as the eye could reach we saw that thousands upon thousands of cattle were being driven away from us. Sir Harry Smith had his spyglass out, and was looking at these masses; we had just got up to the top of the hill, and were intent upon the same object. Hintza had been edging his way to the right, when all at once there was a shout, 'Hintza has bolted!' And indeed he had got a start of at least fifty yards before anyone saw him. Sir Harry threw down his glass, and we one and all dashed after the fugitive; but no horse except Sir Harry's was equal to that of the chief. After about half a mile's race Sir Harry overtook Hintza, and ordered him to pull up; but instead of doing so the chief (who had always been allowed to carry his arms, consisting of the usual bundle of seven assaigais) made a stab at the General. It was well that it was a bundle and not a single assaigai, for although parried with his right 



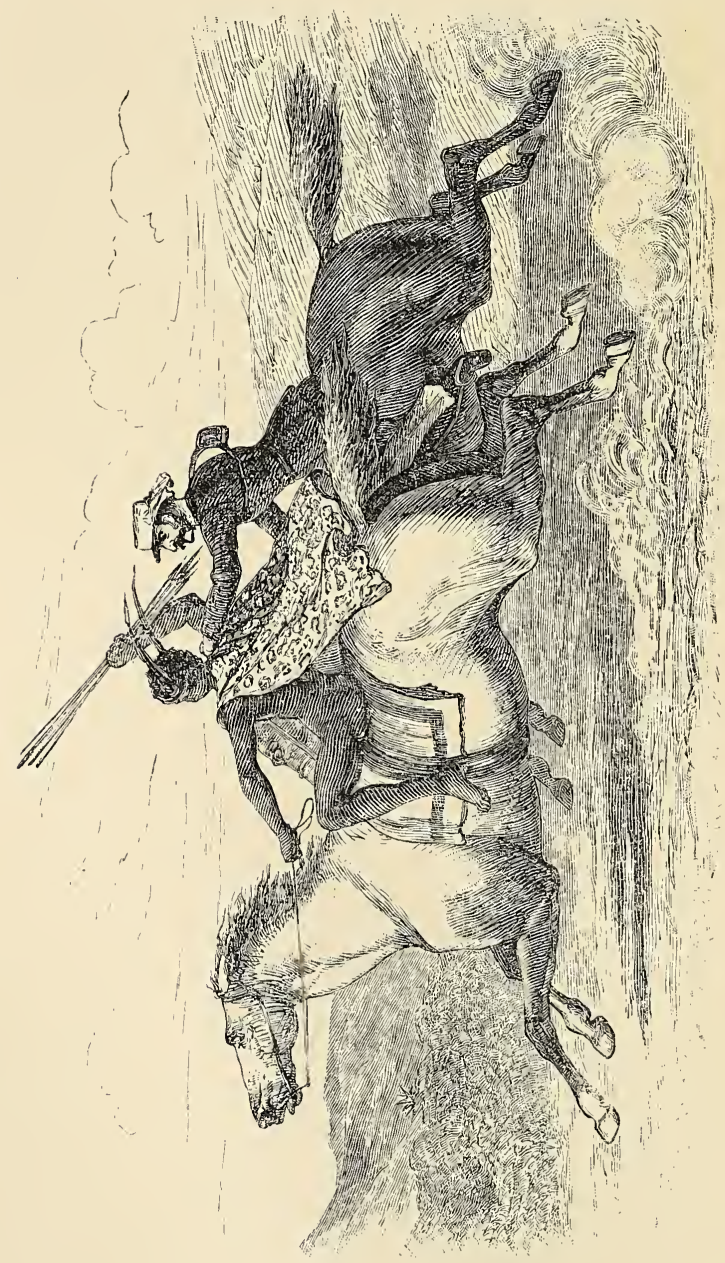

竎 
arm the points of the seven assaigais penetrated his coat over the right breast and slightly entered the skin. In self-defence Sir Harry drew a pistol and again closed on the chief, directing him to pull up, when he again attempted to stab him. Sir Harry then snapped the pistol at his head. Southey, William Southey, myself, William Shaw, old Driver, Balfour, A. D. C. Oliver, and many others were all in this race, but behind. By this time we had come to near the end of the tableland, and could see about 10,000 Kafirs in a semicircle and crowning the hills in all directions. Hintza was making direct for his people, and there was no time to be lost. Sir Harry once more closed with the chief, and this time seized him by the collar of his tiger-skin robe, and slightly dividing the space between the two horses, hurled the chief headlong to the ground. Hintza was on his feet in an instant, and drawing one of his assaigais threw it after Sir Harry; but his horse had bolted from fright at the chief's fall, and the assaigai fell short, but under the horse's legs. Hintza was by this time at the edge of the tableland, and running down the steep face of the mountain. Sir Harry, standing in his stirrups, and shouting to us not to let the chief escape, as we of the chase arrived at the brink of the tableland, we had to dismount and pursue the chief on foot, the ground being too precipitous for horsemen to follow. I fired two shots 
at the chief, but he gained the bush at the bottom of the hill and disappeared. William Southey, Driver, Balfour, and myself were the first to arrive on the spot, and Southey and Balfour entered the bush above, and Driver and myself below, where the chief had disappeared, in order to work towards each other. Southey was the first to come upon Hintza (he was half in the water), a river running through the bush under a shelving rock; he had an assaigai drawn and poised, and was in the act of throwing or jerking it at Southey, when he put up his gun and blew the chief's brains out. I was the first to reach the dead chief. The ball had entered the forehead and completely smashed the skull. I took his assaigais and the charm from around his neck, and left immediately to carry the news to Sir Harry Smith, who, though he did not wish the chief to escape, regretted that he had been killed. It was not until I returned to my horse that I discovered I had lost a pair of valuable pistols from my belt while running down the steep hill. I was sorry for this, as they were 'prize' pistols, captured by my father during the old war with France, were inlaid with gold, and were said to have belonged to Napoleon. The mass of Kafirs collected in the neighbourhood soon discovered that their chief had been killed, and they dispersed after very little fighting. I received my first commission as an officer on that day-May 18, 1835- 
and have been in active service abroad ever since. But to continue. Sir Harry re-formed the troops, and pressed forward after the retreating Kafirs and cattle; and we that night crossed the Bashee, but could not overtake the enemy.

During the night the freshest of the troops were selected to continue the pursuit, and we moved forward before daylight, making a forced march nearly to the Umtata River, during which a couple of thousand or so of cattle were captured. This, however, was but poor compensation for the loss the colony sustained in the death of Major T. C. White, an officer who had retired from the service and become a most enterprising settler at the Cape, where he introduced Merino sheep, and was the originator of every description of progress. When, however, the war broke out he rejoined the service, and was appointed Assistant Adjutant-General to the Burgher forces. He was also a scientific man, and was making a sketch-map of the country we were passing over, remaining with the camp at Bashee to complete his work. He had proceeded to the top of one of the hills, with only a small escort, when the Kafirs crept up the ravines, and made a rush on the party unawares, killing the major and two of his escort.

Major White had been buried before we returned the next day, and many a tear was shed by us over his 
grave. The Kafirs had mutilated the body in a most fearful manner.

On the following day the column of troops returned en route to the Kie, picking up the small camps of tired men, some of whom had been attacked by the enemy, but had heaten them off. After joining headquarters, the whole of the troops recrossed the Kie River and encamped at Fort Warden, on its western bank; and it was from this station that Krielli and Bookoo were some time afterwards sent back to their own country. 


\section{CHAPTER VI.}

THE HIGHIAND MAJOR.

Aт the termination of the Kafir War of 1834-5 the subjugated Territory of Kafirland was held by a military force under martial law, and was at first called the Province of Queen Adelaide, but was subsequently called British Kaffraria.

The head-quarters of the army was stationed at King William's Town, under the command of Sir Harry Smith, and a number of outposts were established throughout the province to keep the Kafirs in subjection.

It fell to my lot to be stationed at Fort Beresford, a post established on the sources of the Buffalo River, near to the forest known as the Buffalo Poorts. This outpost was an earthwork, with parapet and ditch, and built in the shape of a star, with a square of ' wattleand-daub' buildings inside as barracks. The garrison consisted of a company of the 72nd Highlanders, a company of native infantry, and a detachment of the Cape Mounted Rifles. 
A short time after peace was concluded with the Kafirs the commanding officer received orders for a detachment to proceed to the Buffalo Poort forest to cut down timber, wherewith to build a house at King. William's Town for Sir Harry Smith. A Sergeant Cohen and twelve men of the Highlanders were sent upon this duty, and formed a camp under the great trees in the forest, fencing themselves in with an abbatis of bush.

The major who commanded the post was a curious specimen of a soldier of the old school. In those days it was not so much the rank of the officer that obtained for him the admiration of the junior officers as the quantity of liquor he could stow away under his belt, and it was quite wonderful what this old gentleman could do in that way.

A few days after this party had established themselves at the forest I went down to King William's - Town, on leave of absence for the day, returning about nine o'clock P.M. and proceeded at once to report myself. As I rode into the fort gate, the detachment at the forest commenced firing as fast as they could load, and I feared that the bush party was attacked by the Kafirs, and the war broken out again.

The major had a hut with two rooms, into which I hurried to report iny return and what was taking 
place at the forest. He was not in the front room, but I found him in bed in the inner one, and in that glorious state in which it was his pride to be. He was also peculiar in other respects, for he spoke, when he could speak at all, in short sentences, like Jingle, in 'Pickwick;' and when I made him understand that the detachment at the forest was attacked he said, 'Umgad, Bisset-good fellow-go-half-company follow.' I replied, 'All right; I am mounted, and will go on and take command.'

I at once started with my mounted orderly and galloped down a slope of about 300 yards to the Buffalo River; crossed the ford, then raced for two miles and a half, and cantered into the little bush camp while the men were still firing. Luckily I was not shot, and I called upon Sergeant Cohen to report what was the matter. This great Highlander, standing about six feet two, stepped up, and, saluting me in the oldfashioned manner, said : ' $\mathrm{Ah}$, mon, we're attarckedwe're attarcked by the Kaafers; they're shooting (shouting) and hallooing aal roound us-daarnt yer heer thum?' And I certainly did hear ' Boorg, Boorg, Baarg, Baarg,' in all directions at once, all round and above us ; and the more the men fired the more the 'shooting and hallooing,' as the sergeant called it, continued. I at once recognised the familiar screaming and screeching of baboons, and cried out, 'Don't fire another shot, 
CHAP. VI.

sergeant_it is not Kafirs, but baboons.' It was amusing to see the poor Highlander's crestfallen face, and the shame that was depicted on it, as he again saluted me and said, 'Ah, mon, yeere daant say thaat?' 'But I do say it, sergeant, and it is a false alarm. However,' I continued, 'stand to your arms; you will soon be reinforced from the post, and I will go back and report to the major.'

I rode back with my mounted orderly, and half-way to the post I met Johnstone, the colour-sergeant, with half the company, on the 'double' to join their comrades. I told the party what had happened; and the - replies of astonishment were made in the same dear old Scotch accent-the 'rhythm' of which thrills through me even at this moment as I write. I told the sergeant to take his men on and reinforce the camp until I brought him orders, and that I would report to the major. When I got to the post I found the men were turned out and had manned the breastworks, while the guard had fallen in, with fixed bayonets, at the gate. Everything was on the alert, and I was challenged in due order; but on asking for the major I was told that ' the meegar had meounted his horse and gane after the partie.' Now, I had come by the only road from the forest, and not meeting him I became alarmed, thinking there might possibly be Kafirs about, and that he had fallen into their hands. At this 
moment up trotted the major's fat old charger, neighing as he reached the gate, glad to get back to his stable, but without his master. This looked still more serious; and directing six men to follow me at the 'double,' I went in search of the 'meegar.'

As I said before there was a run down-hill of about 300 yards before reaching the river, the ford of which was about thirty yards wide, and not quite kneedeep; and if I had had a gun with me I should have shot the commanding officer, who was in the middle of the ford, making such a splash that I took him for a sea-cow or hippopotamus. $\mathrm{He}$ was striking out most manfully and trying to swim, in order to keep his head above water, but was so drunk that he could not stand.

The Highlanders stood with their arms at the 'order' and their other arms akimbo, and were laughing enough to kill themselves; but not one bit could I get them to go into the water and bring the major out. At last I had to give a peremptory order, and they marched in and brought him to dry ground.

The old soldier had always a habit of clearing his throat before speaking, and directly he saw me he did this once or twice, and then continued: 'Um-gad, Bisset - horse vicious - kicked up - fell — soft, like feather-bed.' The fact is the major had managed to sit his horse until he got to the water, and when the 
nag put its head down to drink the slight propelling power from the bridle was quite sufficient to send the old fellow over its head into the water ; and then, as he could not stand, he had nothing to do but to strike out and endeavour to swim. It was the most ludicrous sight I have ever seen.

The men had to support or partly carry him back to the post; and when we got him into his bedroom and undressed him the room became saturated with blood and bloody water from inside his boots, and from his clothes. The fact is the water where he fell was so shallow in parts that he had fallen upon the point of a sharp stone, which cut an artery in the groin, and it was spirting, and bleeding at a great rate. There was no docter at the post, but I had heard of colowebs, and the inside of the huts was literally covered with them. I made the men collect quantities, which we piled on, and by using pressure partly stopped the bleeding, whilst I sent off an express to King William's Town for a doctor, and in about two hours old Tim Graham arrived and took up the artery. He was just in time, for the old soldier had fainted, and was only restored to consciousness by a little of the stimulant that had caused the fall-on the principle, I suppose, of ' a hair of the dog that bit him.'

This terminates the story of the hairy Highlanders, but I cannot resist in continuation telling three or 
four more anecdotes about the old major. Two of the incidents occurred at the same post; the other two at Commetty's Post, on the Fish River, after the troops had retired from the Province of Queen Adelaide to that ' line of defence.' On one occasion Fort Beresford caught fire. The wind was blowing a perfect hurricane, and in the centre of the fort, or square, there was a magazine, containing a great quantity of powder. The barrack huts and the magazine were thatched with rushes, and two sides of the square of huts were already consumed by the fire; the third face had caught, and the flakes of flame were flying on to the magazine, which had already twice ignited and been put out. All at once a murmur arose amongst the Highlanders that it was time to abandon the post, for fear of being blown up; but the major hearing it, called to his old stand-by, Sergeant Johnstone, and clearing his throat and with a ' bended knee,' said, ' Um - gad-lift,' and was hoisted to the top of the magazine, when he exclaimed, 'Um-gad-blow-up-all -go-together-put-out-fire,' at the same time tramping out the flakes of fire as they fell on the inflammable roof of the magazine. This put fresh spirit into the soldiers, and they worked with such a will that the fire was soon put out and the remainder of the post saved. Did he not deserve the Victoria Cross?

After the Province of Queen Adelaide had been 
occupied for about a year or so the policy of the good and philanthropic Governor, Sir B. D'Urban, was reversed, and it became known that the province was to be abandoned to the Kafirs, thus enabling them to revert to their savage customs. This new order of things emanated from 'home,' in accordance with the policy of the then Government during Lord Glenelg's term at the Colonial Office. It so happened that a suttler named Lucas (a discharged sergeant-major from the Cape Cavalry) had built a very good house, which actually had a firegrate in one of the rooms-a rare thing in those days. Hearing that the province was to be given up to the Kafirs, he sold the house to the major for a mere song; and the old soldier was so proud of the grate that although it was summer, and the thermometer at $90^{\circ}$, he would always have a fire in it.

On a particular day I had again been to King. William's Town on leave; and returning at about four o'clock P.M., I went to report myself as usual, but could not find the commanding officer in any of the rooms. In the grand room there was a table, with a flowing cloth on, and on the table was an empty bottle and an overturned water-jug.

I was about leaving the front door of the house, when I heard the clearing of a throat which I knew well; and going round to the 'grate' side of the table, 
I there found my old friend under it, with his bald head within a few inches of a roaring fire, and the perspiration pouring off it in large drops. When he saw me, he exclaimed, 'Um-gad, Bisset-coolest place in the house,' to make me believe that he had got there of his own free will, whereas if I had not come in when I did he would have been a ' cooked man' in more senses of the word than one. With the aid of a servant we got him into bed.

From the Province of Queen Adelaide the troops marched to take up the Fish River line of defence, and the major 'took up' Commetty's Post, on that river. Being a field-officer commanding, he had a sentry posted in front of his own hut, which had also a porch to it. To show what sort of a figure this old warrior possessed, and how hazy he was when he got up in the morning or rather at about noon-when he generally made his first appearance-I must mention that, on one occasion, when he came outside, the sentry instead of 'throwing his musket up and catching it,' as the ladies call presenting arms, brought it to the ' carry,' with a broad grin on his face. This put the major on his metal, and, clearing his throat, he said, 'Um-gad-field-officer-present arms-make prisoner.' The sentry now certainly 'presented,' but he laughed outright, whereupon the irate officer called the sergeant of the guard to confine him; but this staid old 
Highlander, saluting his commanding officer with austere respect, touched him on the shoulder, and asked him to step into the porch of his hut; and he then pointed out to him that the shell-jacket which they wore in those days had been put on upside-down, and the lower end, or lappets, which should have come round the waist (and the major's was not a small one), were projecting well past the front of his face, and the collar of the jacket was about half-way round the body. I need hardly say the sentry was released.

There was a detachment of Cape Mounted Rifles at this post; and the major had the habit of walking a sort of 'quarter-deck' walk up and down the parade while 'stables' was going on in the afternoon. The first officer in command of the detachment was a respectful young fellow, named Harding (poor fellow! he was drowned afterwards at the Fish River mouth), and when the horses were cleaned he would go up, salute the major, and ask if he might dismiss the 'parade ;' and the major invariably replied, 'Um-gad-yessound feed.' In a short time Harding was relieved by a young officer-a Young England, young anything-what we called a 'haw-haw' fellow, but who has since turned out a first-rate officer. At his first parade he walked up to the major, and giving him a slap on the back, exclaimed, . 'There, major, what do you think of that for a horse?' pointing to his first charger, Chanticleer. The major 
started as if electrified, became red in the face, and I don't know how many times he cleared his throat before he could get out ' Um-gad-young man-presumption-major in the army-young man once-took the Cape-eat water-melons.' Thereby meaning that he was at the taking of the Cape of Good Hope in 1806, in the same fine old regiment under Sir David Baird, and that he then ate water-melons. 


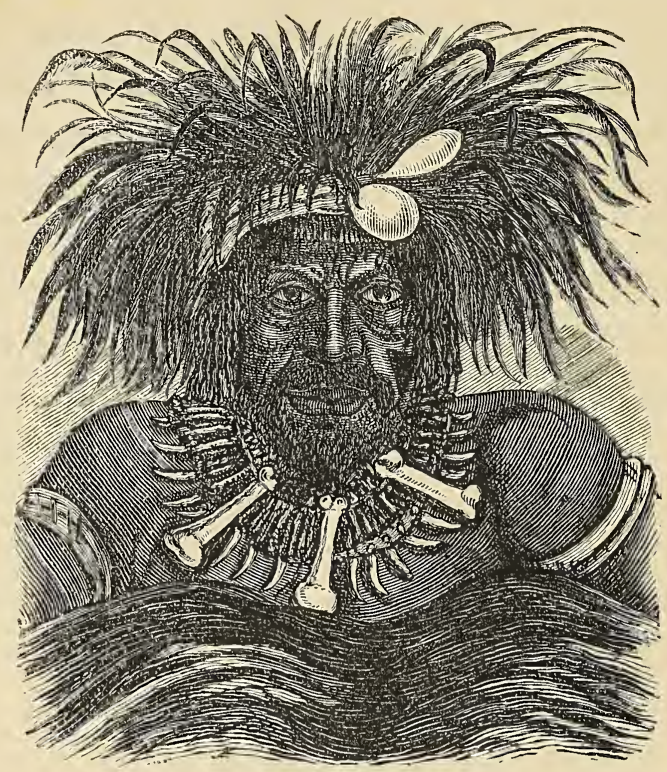

A WITCH-DOCTOR.

\section{CHAPTER VII.}

THE WITCH-DOCTOR.

When a youngster, and stationed at Fort White, in the Province of Queen Adelaide (now British Kaffraria), at the termination of the Kafir War of 1834-5, I witnessed the following extraordinary and revolting sight.

A rich Kafir residing in the neighbourhood became what he called ' bewitched,' and nothing could persuade him that animals or reptiles were not devouring him in 
the flesh. He had great pain all over his body, but particularly between the shoulders, and had paid several 'witch-doctors' so many head of cattle to rid him of the evil spirits, but could get no relief. It becoming: the common talk amongst the officers of the post, our English doctor went to see him, and declared him to be suffering from acute rheumatism. He would not, however, hear of any treatment by the white man, but sent for a celebrated witch-doctor from the interior of the country. This hag at last presented herself, and the imagination could hardly picture such a hideous creature. Medusa must have been a beauty in comparison. She was wizened, with thin legs and body, except that part below the belt, which stood out like a barrel-organ; and the bosoms, the great charm of the fair sex, were in her the most repulsive feature of all ; in fact they were mere leather bags, the one hanging down far below where her waist ought to have been, and the other thrown over hershoulder. Her eyes were like those of the cobra, her hair a tangled mass of close clotted wool, like that of an uncombed poodle, with fishes' bladders and the insides of reptiles tied to each point or extremity of her tangled locks. This she-devil, or witch-doctor, first commenced to 'smell out' the bewitching matter. This she did in a variety of ways, by crawling about the hut and round it outside, by making piles of cow-dung and burning 
CHAP. VII.

charms, by gesticulations, yells, and exorcisms of all sorts; but first of all demanding ten head of cattle, five of them to be paid at once, and the remainder to be guaranteed on the cure being effected.

We officers used to go down to the kraal and watch all these diabolical proceedings, and were invited to be present and see the animals or reptiles extracted from the living man.

First the patient had to be 'overhauled' by this fearful specimen of humanity. He was evidently in great pain; but she had no mercy - his arms and legs were pulled, his body pinched, pumped, and squeezed until he bellowed like a bull. At last she found the most tender point-at the extremity of his right shoulderblade; then she began to make all sorts of fantastic gyrations, and declared that the reptiles were there, and that she would bring them forth and exhibit them.

Again she howled and crawled round the hut, and returned with a dry ' $\mathrm{cob}$ ' of the Indian corn, with the grain taken off it, which leaves the cob itself like a round rough rasp. With this improvised instrument she approached the sick man, and commenced to rub him on the shoulder-blade until she had nearly rubbed through the skin. She then applied her mouth and commenced to suck at the spot until a regular stream of blood followed.

At this stage of the proceedings the hag, yelling 
and gesticulating, rushed from the kraal down to a little rivulet close by, where she had been seen to go several times during the morning; she returned in a few minutes and again applied her mouth to the now open wound and brought forth a renewed stream of blood. She now desired everyone to search her; and I can assure you she had very little clothes on in which she could hide anything; but she made us look into her mouth, and even into her ears. She then re-applied her mouth to the sick man's sore and spat out a quantity of blood and-and-a grasshopper! ' There,' said she, 'is the monster. But there are more.' And after showing us her blood-stained mouth she again proceeded to suck, and this time spat out a blackbeetle! The wonder became great, and the Kafirs exclaimed 'Mar-whow!' (a wonder); but she again acted the 'vampire,' and out came a lizard, a long, narrow, crawling reptile. The sick man became excited and said he was better; but the witch-doctor was not yet satisfied. Sucking the open wound again, she spat out another mouthful of blood, and in it a matted clot of hair. 'There,' said she ' is the bewitching matter,' and the bewitched man is disenchanted! We young fellows all looked amazed, and the Kafirs were fully persuaded of the witch's spells and power of cure; and, what is strange but natural, the sick man got quite well. 
Here was a pretty mystery to unravel, and we were determined to do it. The 'deformity' remained to see that there was no return of the evil spirits and to get paid the remaining five head of cattle.

During this time we subscribed the sum of five pounds to get the 'she-devil' to reveal the mystery to us, but she refused. Then we converted it into silver, and again tempted her, but to no avail. Next we turned it into copper, when it appeared in her eyes as untold wealth. However, she was still obdurate. As a last resource, we converted the money into Kafir 'truck,' in the shape of tinder-boxes, steels, brass wire, beads, looking-glasses, knives, handkerchiefs, \&c., \&c. This looked such a quantity of riches that she began to give way; and after making us swear by the God of the white man that we would not divulge her craft, and after looking about to be certain that no native eye or ear was near, she revealed the secret of her diabolical process.

It was simply this: she had collected the reptiles we saw her produce, with many others, and had them enclosed in a calabash. When she ran down to the water she gorged herself to such an extent with fluid that she could contain no more, the habit of which had given her that graceful figure which I have alluded to; and when so gorged she swallowed not only what we saw her reproduce, but as many more of the most 
horrible things in the world; and she had the power by an effort of nature to bring these living monsters back into her month. The 'counter-irritation,' the bleeding, and the imagination cured the 'bewitched' man of his rheumatism; but he and his benighted brethren would never believe but that the living creatures had been extracted from his body! 


\section{CHAPTER VIII.}

MY FIRST LION-HUNT-1839.

Ar the termination of the Kafir War of 1834-5, or rather when the Province of Queen Adelaide was surrendered back to the Kafirs, the troops were withdrawn to what was called the Fish River line of defence ; and the provisional officers, who had served first in battalions of native infantry, and were subsequently attached to the regiments of the line and Cape Mounted Rifles, were disbanded. This was towards the latter end of 1839. The officers received a gratuity of six months' pay, and it was during this 'interregnum' of my military life, or while $I$ was in receipt of this pay without work, that the adventure happenèd which I am about relate.

I must, however, observe that there was really no 'interregnum,' as I was re-appointed to the Cape Mounted Rifles before these six months expired, and my pay thus 'overlapped.' But to proceed. I devoted these six months to a shooting expedition into the interior of Africa. Money was not very plentiful. I 
started with a single pack-horse and an admirable shooting-horse for myself. I could not afford an 'afterrider,' but it so happened that my second horse required no one to lead him. I bought him at a ' cast sale,' that is, at a sale of cast horses of the Cape Mounted Rifles. He was a strong, podgy little horse, of good breed, called Pompey. He had been for many years the 'orderly's horse' to our colonel, and was accustomed to keep orderly's distance in the rear, or about thirty yards from the colonel; and this had become so much his habit, that go where I would, and at any pace, there was my pack-horse always behind me. The difficulty was to carry all I wanted in the way of ammunition and an extra gun, with one spare horse. However, I had to do it, and started from Graham's Town viâ Fort Beaufort and the beautiful valley of the Blink Water, passing the Didema Mountain and over the great Winterberg into the Tarka; thence over the Sneuw (snow) Berg to Cradock. This district was at that time abounding in game, and I remained for nearly a month with old Lieutenant John Crause, one of the old soldiers of the Duke of York's day, who, it is said, got his commission before he was born.

I was joined at this farm by a nephew of mine host named Percy Crause; and after re-fitting he and I started for Buffles Vley, just then beyond the borders of the colony. 
On the evening of our second day we got to a Dutch farmer's hut, and found the men at target-practice. This being such an unusual thing in those days, when lead and powder were both scarce, we enquired the reason, when old Dederick Putter told us that the lions had the night before killed the two 'wheelers' of his team of horses, and that the boys were putting their guns 'op schot,' or sighting them, to go after the lions the next day. He invited us to join them. This we were delighted to do, and halted for the night accordingly. Our guns were also tried, and none of us were satisfied until we could hit the small knuckle-bone of an ox-the knee-cap or joint from between the two long bones-at eighty yards' distance.

There were five Dutchmen and ourselves, seven in all. We started at daybreak the next morning, and made for the spot where the two horses had been killed. It was one of those mornings in South Africa when a thick fog precedes a very hot day. We reached the dead horses-or rather what was left of them, for there was nothing remaining but the backbones and headsjust as the sun had risen. The mist was so thick that the rays of the sun made a complete halo round you for about twenty yards distant, and beyond that distance you could see nothing. This made it the more critical, as the lions had only left the carcasses just as we got to the spot. We could tell this by the sparkling dew 
having just been knocked off the grass and not replaced by the heavy mist. We counted the 'spoor' or trace of seven lions, and could not tell at what moment we might come up with them, for we could ride at a fast walk on their track. All at once we came to a deep gully, about eight feet deep and twenty or thirty feet wide; into this gully the lions had jumped, and we had to follow the 'spoor' by riding on the bank above. These gullies are numerous in that part of the country, and are formed by the heavy rain or thunderstorms; they continue for some miles on the flat grounds, starting from the foot of hills or mountains. We knew that this gully must soon terminate, as we were then approaching Tea-bus, or Tea-canister Mountain, so called from its likeness to that article of furniture of the Dutch shape. When we had got to within about 200 yards of the termination of the gully, and close to the mountain, out jumped the seven lions-two males, two lionesses, and three cubs. They walked majestically away from us, rather to the right, so that we had to continue to the head of the gully before we couid get at them, and the lions were then about 150 yards from us, and a little scattered, a great black-maned lion being on the left. Old Dederick Putter, who had. been appointed captain of the hunt, told us to dismount hastily, which we did; the horses were then turned with their tails to the lions, and were held by the bushmen 
after-riders, while we formed up between the lions and horses, the Dutchmen telling us that if the lion charged us and we did not kill him we were to retire through or between the horses, whereupon the lion would spring on a horse. When we were all ready he directed a young Dutchman, a nephew of his, named Streydom, to fire a shot, not at but to the left of the left-hand male lion. The ball struck the ground about forty yards from the noble beast and raised the dust. The lion made one spring at the spot, and was seen clutching the air in the utmost rage; but without one moment's delay he turned on us, and, lashing the air with his tail, came towards us, alternately making short springs and crouching. We stood with our rifles ready and the finger almost on the trigger. The 'captain' told another young Dutchman to take aim and fire at his own time, while we all stood in reserve. This young farmer immediately sat down, and, with his elbows resting on his knees, waited till the lion was within about sixty yards, when he pulled trigger and the ball entered one of the brave beast's eyes. The lion bounded into the air, making a spring to the front, and then a second one, which brought him to our very feet, where he was despatched by several shots. The lion's face was perfectly covered with the brains that oozed out of the bullet-hole; and the other eye was so covered that I attribute our safety partly to that circumstance. During 
this time those who had fired were rapidly re-loading; and it is well that this was done, for without any further provocation the second male lion, a large brindled one, with a short, upright mane, at once turned and came on to attack us. The horses were much frightened, and kept turning about; but we were too intent watching the lion to prevent it. This time old Dederick turned to me and said, 'Englishman, it is your turn to fire first.' I thereupon stepped three paces to the front and stood waiting for the noble brute. $I$ allowed him to come rather nearer, and he was about forty yards distant when I fired; and I should possibly have allowed him to take another short spring first had it not been that the Dutchman kept saying, 'Schiet! Schiet! Allemagtig Engelschman, Schiet.' They were not, however, disappointed; my ball entered the front joint of the shoulder and passed out on the opposite flank, and the brute rolled over at once; but although the bone was broken high up the lion was up again in a moment on his three legs, and came on bounding as if nothing had happened. My friend Crause fired another ball into the lion's head, and several other bullets passed through its body. By this time the remaining lions were near the foot of the mountain, but two of the cubs were to the right of the others. We at once mounted our horses and cut them off from the bush and rocks at the foot of the hill, and before they could get 
into another gully had shot them from horseback, without much danger to ourselves, making a bag of four killed, which was not considered bad sport even in those days.

The next thing was to skin the lions, which the after-riders did in the most expert manner ; but none of the horses would allow the skins to be put on them to be carried home, except my old trooper, who did not so much as wink his eye, having considered it, I fancy, a rather good field-day.

One thing struck me as very curious-- the two male lions, which were of enormous size, were of distinct species, although they were fraternising together. The first one killed was a large cream-coloured lion, with black hairs intermingled, and a mane larger and longer than any horse's, broad, spreading, and more ragged; while the other was of equal size and age, but entirely brindle and of one colour, while the mane was short, scrubby, and upright. The cubs were, I think, of the short-mane species.

The skins of the two lions were given to Crause and myself, and I sent the black-maned one to follow Sir Harry Smith to India ; and he long used it as a carpet for his tent, a worthy one for the lion-hearted old soldier During this shooting expedition we shot several other lions on the Modder and Vaal Rivers; but our sport in the interior will be the subject for another paper. 


\section{CHAPTER IX. \\ THE ' WAR OF THE AXE'-1816-7.}

WIrH savages wars do not arise from political causes, but chiefly from the wish of the young men to distinguish themselves and become 'warriors.' Up to the age of sixteen the boys remain boys, or, as they are called, 'amacanquas.' The rite of circumcision is performed on all the young men at the age of sixteen, who are thus made 'men,' or 'amadodas.' Although they thus become nominally men, they only become warriors after a war or after some act by which they have distinguished themselves-hence after a few years there are so many young men, that their councils outweigh the councils of the old men, and they declare for war. It is what they call growing 'fat,' or in a state of preparedness. Once in this condition there is no difficulty in finding a pretext, and the war of which I am now writing was called the 'War of the Axe,' from the trivial circumstance that gave rise to it.

Fort Beaufort and the town of that name were then situated on the very borders of Kafirland, and 
the Kafirs were 'fat.' Two Kafirs, men of some importance among the tribe, stole an axe from a shopkeeper in the town of Beaufort; they were caught in the very act and secured.

Criminals at the Cape are tried at the circuit courts about every six months, but the circuit judges do not go to all the small towns, and the prisoners from Fort Beaumont had therefore to be sent for trial, to Graham's Town, a distance of over fifty miles, and the main road from the two places ran almost parallel with the Kafir border.

The prisoners were sent from Fort Beaufort in charge of civil constables, and when they had got about twelve miles on the road they were attacked by a body of Kafirs from across the border; and although the constables made a fight for it they were overcome, and the prisoners were rescued by the Kafirs. It so happened that the two Kafirs, whom they were most desirous to release, were handcuffed to two other prisoners, who were British subjects; and as time was precious, in order to escape with their countrymen they murdered the two men to whom they were attached, and cut off their arms at the elbow-joint, in order to free the Kafir prisoners. Hence the War of the Axe.

The Government demanded that the prisoners should be restored and the murderers surrendered; but the 
demand was treated with contempt. The young men wanted war, and war they would have.

First a 'palaver' took place at Block Drift mission station, afterwards Fort Hare, where the then Lieut.Governor and senior military officer on the frontier met the Gaika chiefs, with a large retinue of their people. The Lieut.-Governor luckily had a small body of troops with him, who were drawn up in line while the negotiations were going on, in the presence of the three Gaika commissioners. The Kafirs were in number as ten to one; and as they were drawn up facing the troops in a great mass, they repeatedly opened out, extending their front, so as to outflank the European troops; and this was only prevented by judiciously extending the rear-rank men right and left. This manœuvre probably saved the small force from being surrounded and attacked, as it was afterwards ascertained that the Kafirs had fully intended to attempt this treachery.

The meeting, however, broke up without collision, and the troops returned to Victoria Post, a new military position which had recently been established east of the actual colonial border, on what was formerly called the Neutral Territory, between the Kat and Keiskama Rivers.

After some considerable delay the troops were ordered to take the field and enter Kafirland, with a view to bring the refractory chiefs to order. 
Two columns of troops left Victoria, one under Colonel, subsequently General Sir H. Somerset, and the other under Colonel Richardson, 7th Dragoon Guards. Very little except ordinary skirmishing took place for the first two or three days ; on the third day a combined camp was formed on the Debe Flats, just under the Taban Doda Mountain. This was the same locality where Sir B. D'Urban formed his camp in the war of 1835; and I remember going to look at the very spot where Sir Benjamin's tent stood when he was very near being assassinated by a Kafir who had crept through the sentries into camp, had penetrated into the Commander-in-Chief's tent, and was in the act of stabbing Sir Benjamin, when he was shot by the sentry over the tent.

On the fourth day the camp broke up, and the two columns, forming one division, entered the Amatolas in the direction of Burns Hill, a missionary station, also the residence of the august paramount chief Sandilli. I was sent on with an advance-guard, or reconnoitring party, to take possession of the chief's kraal. The mission station was in a most deplorable state; the missionaries had fled, the furniture was smashed to pieces, and the Bibles and books scattered to the winds, but up to this time the houses had not been burnt. Sandilli's kraal was also deserted, but at the door of his hut I found his emblem of royalty, viz., two lions' tails 
dried, on sticks stuck in the ground on each side of the hut-door; inside the hut I found a musket and some gourds of sour milk.

The troops soon followed, and a combined camp was again formed at the mission station. During the day Major Sutton also joined the force with a ' commando' of Hottentots from the Kat River settlement, and formed a separate camp on a peninsula across the Keiskama River.

At daylight next morning the troops took the field in three columns. The right, or infantry column, under Major Campbell, 91st Regiment, entered the Amatola Mountains at the gorge of the Amatola Basin, with Mount MacDonald on the right, and the Seven Kloof Mountain on the left. The centre column consisted entirely of horsemen, the Cape Mounted Rifles, under Major Armstrong, and the Kat River Burghers, under Major Sutton; this "column, after crossing the Keiskama River, climbed up one of the ridges of the Seven Kloof Mountain to its summit ; the third column, under Generals Somerset and Richardson, consisting of the 7 th Dragoon Guards and Cape Mounted Rifles, continued on under the Seven Kloof Mountain, in the direction of the Chumie Hoek.

I was with the centre column; and as we reached the summit of the Seven Kloof Mountain we could hear the infantry in action in the Amatola Basin, on 
our right; but immediately on our own right front a large body of the enemy were drawn up in the shape of a crescent, with a dense forest immediately in their rear; and, to make the position more difficult, there was a tangled mass of bramble-bush and swamp between us and them.

The Kafirs having challenged us to battle, a consultation took place between Majors Armstrong and Sutton, who decided that we could not in their then position attack them. I was only a subaltern in those days, but I remember that we were all very much disgusted at the disappointment; and, to make things worse, as the column was marching right in front the major wished to counter-march it in the face of the enemy, to make the men front towards the Kafirs when halted. My friend Johnny Armstrong (lieutenant) commanded one squadron and I another, and we both remonstrated against this move, but halted and fronted to our right. This brought us at once face to face with the enemy, although inverted by threes. We were both reprimanded for this afterwards, but I am quite sure it was the only thing to do. Had the counter-march been continued it would have appeared to the enemy like a retreat, and an immediate attack from them would have followed, while the men were in confusion, for the Kat River Volunteers knew very little of any drill. As it was our front and advance dispersed the 
enemy at once, in so far that they moved back into the bush. But we had scarcely moved on in the direction to join General Somerset when the Kafirs attacked our rear, and we had to make a sort of skirmishing fight until we cleared the ridge of the mountain and got somewhat into the open. All this time there was very heavy firing going on with the infantry column on our right. As we moved down a hill on to a low ridge dividing the Amatola Basin from the Chumie Hoek, at the base of the Hog's Back Mountain, the infantry column made its appearance, coming up the face of a steep hill out of the valley of the Amatola. They had been attacked immediately after entering the gorge of the Amatola Basin, and had some desperate fighting all the way to where we saw them still in action, and were very much pressed by the enemy. There were no means of carrying the wounded, and most of them fell into the enemy's hands.

Between us and the infantry was a steep rocky ledge so that it was quite impossible for the cavalry to go to their support. The infantry, however, fought their way on towards us and this ledge, where the ground became comparatively open. Several men fell between the ledge and where we were drawn up ready to charge, should the enemy come into the open; and as the Kafirs showed in some force there we charged down on them, dismounted on the brink of it, and drove them 
back on foot. Two men were shot-Booy Daries and Witbooy Klein, one at my side and the other next Lieut. Carey-and some few men and horses were wounded. We very soon drove the enemy back, and held the rocky ledge until we were recalled, after having been reinforced by Capt. O'Reily's troop. Our holding the ledge enabled the infantry to carry back the wounded who fell after they passed over it.

By this time General Somerset had come from the direction of the Chumie Hoek to our support with the two field-guns which accompanied his column from the camp at Burns Hill. These were soon got into position, and the enemy was shelled out of the bush and rocks. in a very short time.

Here again-as in all Kafir wars-the Kafirs had such power of dispersion that they soun disappeared except on the distant hills. The troops were ordered to re-form, the wounded men were placed on the gunlimbers, and the whole of the troops then marched down the slope to the Chumie Hoek. At the foot of the hill we were joined by Captain Donovan, Cape Mounted Rifles, Captain Pipon, who had been detached by General Somerset up the sources of the Chumie River, where they had captured about 2,000 head of cattle and a number of goats and other animals.

Major Gibson, 7th Dragoon Guards, and the remainder of the troops had been left in charge of the 
camp at Burns Hill; and as it was now late in the afternoon, and it was quite impossible to guard these cattle back over the bushy country to Burns Hill, General Somerset decided to form a camp for the night in the open plain just under the high point of the Seven Kloof Mountain, between the sources of the Yellow-wood stream. Before so doing he despatched a party under Lieut. Stokes to communicate with the camp at Burns Hill, directing Major Gibson to march, guarding the camp, the next day, and join us at the Chumie. This party had to fight its way the whole distance to Burns Hill, losing two men and several horses wounded.

The camp at Burns Hill had also been attacked during the day, and a number of the draught and slaughter cattle captured by the enemy ; and a squadron of cavalry was sent out under a fine old Waterloo officer, Captain Bambric, 7th Dragoon Guards, to endeavour to retake the cattle. This party, which consisted of the 7th Dragoon Guards and Cape Mounted Rifles, the latter under Lieut. Boyes, followed the Kafirs into the bush, when they were attacked in such force that they had to retire, not, however, before the gallant old captain had fallen a victim. The Kafirs stripped his body and held it up in triumph; and although several attempts were made by the troops they could not recover the remains.

I must now return to the camp at the Chumie 
Hoek. I had the formation of this camp, which formed a square of 120 yards each way, the men lying on their arms and facing outwards, the horses being linked in rear, and the cattle and goats in the centre.

Sentries had to be posted between the horses and the cattle, and vedettes at a short distance outside the square. The camp was twice attacked on one side during the night; and after the vedettes ran in, that side only returned the fire of the enemy, although in the dark of night, the other faces of the square merely standing to their arms. This showed great steadiness on the part of the soldiers.

The next day was a most memorable one in the annals of Cape warfare. As the camp began to move from Burns Hill, with its long train of bullock-wagons, over one hundred and twenty in number, besides Royal Artillery guns, limbers, and ammunition-wagons, thousands upon thousands of the enemy were seen pouring down from the mountains in all directions. The road, a mere wagon-track, ran for the first two miles along the bank of the Keiskama River ; the river, then turning suddenly to the right, ran round a peninsula of high ground, upon which old Fort Cox, of the Province of Queen Adelaide day, was afterwards rebuilt. At the base of this peninsula, which the road crossed before descending to cross the Keiskama River, the wagon-road ascended a stony, precipitous, and 
bushy space of about half a mile. The Kafirs were all massing towards this point for the attack. The front wagons, which consisted chiefly of those belonging to General Somerset's column, were so well protected by the advance-guard that they passed safely over this difficult point and descended towards the Keiskama ford. The Kafirs, however, made such a vigorous attack on the centre of the long line of wagons that they drove the escort defending them back on the main body of the troops in the rear, thus capturing the wagons in the narrow part of the road. The Kafirs immediately cut the oxen loose from the yokes, thereby entirely blocking up the road, so that no other wagon in the rear could pass. During this time all the available troops from General Somerset's camp were sent to the assistance of Major Gibson-Major Sutton, with the Kat River people, and Captain Scott, with 120 of the 91st Regiment; but the Kafirs came down from the mountains in such overwhelming numbers that Major Gibson was obliged to abandon the whole of the wagons (fifty-two in number) belonging to Colonel Richardson's column, ${ }^{1}$ and had to make a détour to the

1 The baggage-wagons of the 7th Dragoon Guards contained kits belonging to the officers of considerable value - it was said to the value of $900 l$. or $1,000 l$. Some officers had two or three guns in their waggons by the best makers, Purdy, Rigby, Wilkinson, Moore, W. Richards, \&c. These superior arms unfortunately fell into the enemy's hands, while the officers only got about $36 l$. each as compensation for losses. But this of course was their own look-out. 
left along a bushy slope with guns, limbers, and ammunition-wagons. With these the major had to fight his way across the Keiskama River and up the long bushy valley under the Seven Kloof Mountain.

I had been sent forward by General Somerset to hold the ford of the Keiskama River, and to defend the rear of the First Division wagons, directly I was replaced at the ford by the advance of Major Gibson's force. I came up to the rear of the wagons whilst being fiercely attacked; and as Lieutenant Cochrane, 91st Foot, was at that moment wounded, the command devolved upon me. There was very hard fighting for some distance, but at last we cleared the bushy country and gained the open. We reached the camp without further fighting. During this day my charger was shot under me, my gun was shattered to pieces in my hands, and several men were killed and wounded. General Somerset's orderly was shot, and the general's charger, which he was leading, fell into the enemy's hands.

During all this time Major Gibson was fighting his way over the same ground, with the Royal Artillery guns, limbers, and ammunition-wagons which he had saved from falling into the hands of the Kafirs. As night was closing in Major Gibson's column made its appearance in the open about three miles from our camp. As they were leaving the bush country the enemy made a general rush on the rear; but the guns 
opening almost in the dark on them, they were repulsed, not, however, without two or three wounded men falling into their hands, as also a Royal Artillery limber-wagon, with gun ammunition. This was on account of the bullocks knocking up and being unable to proceed. Major Gibson then marched on and joined our camp. Early in the morning of this day Lieutenant Boyes with ten men had been sent from Burns Hill camp with a despatch reporting the occurrence of the day before and the loss of Captain Bambric, and his small escort had to cut their way through large bodies of the enemy. Five of his men were killed or wounded.

The camp was several times attacked during the night, but the enemy were beaten off without much loss on either side. Orders were also given for the camp and troops to move the next day to the mission station at Block Drift. As daylight broke the whole of the mountain range above the camp was seen to be densely crowded with the enemy, and masses of mounted men were formed on the lower grounds of the Chumie range. Before the troops moved off I was sent back with my squadron of Cape Mounted Rifles to endeavour to recover the ammunition-wagon abandoned the evening before. As I marched towards the bush country large bodies of Kafirs moved down the mountain, but did not come into the open. As I approached the ammunition-wagon a most horrible and ghastly sight 
met our view. One of the wounded men who had fallen into the enemy's hands the night before had been lashed to the limber of the wagon and burnt alive. A most ghastly grin was on the poor man's face; his wrists and legs were lacerated with the thongs, and his body charred by the fire; his belly was ripped open by an assaigai, and his bowels protruded. The ammunition-boxes had been cut loose from the wagon and emptied of their contents, but the wagnn itself was burnt to the axles, and the shot and shell were still hot.

A portion of the camp had already moved off before I returned, and I was told off with my squadron to form a rear-guard. As the leading wagons moved from the camp the two great masses of the enemy poured down from the mountains and extended along the whole line of route; and as the wagons approached the bushy country towards Block Drift the whole line was simultaneously attacked in front, centre, and rear; but the guns being brought into action, the enemy were driven back with considerable loss. Colonel Richardson commanded the centre and rear of the wagons; and the 7 th Dragoon Guards had several times to charge the enemy.

Just as I was moving from the camp-ground with the rear-guard I saw a splendid fellow of my regiment, Corporal Telemacus, and one man come galloping in from the direction of the affair of the day before. 
They turned out to be all that were left of an escort which had started from Victoria Post to follow the troops with despatches from his Excellency Sir P. Maitland, the Governor and Commander-in-Chief, who had arrived on the frontier from Cape Town. This corporal had been despatched with six men, and followed the 'spoor' of the troops first to the Debe Flats; then, pushing his way towards Burns Hill, he was met at a 'neck' dividing the Amabalas from the Taban Doda by a body of Kafirs. These he charged, but lost two of his men. He then pushed his way on; and seeing the line of wagons taken by the enemy the day before, for a moment thought it was the camp on the move, but found the wagons in possession of the enemy, who were still burning them. He was then headed at the Keiskama River, where he lost two more of his men, and he reached the camp at the Chumie with only one man, both their horses being wounded, one through the saddle-flap and into the side, and the other in the thigh. I sent the despatches on to the head of the column by fresh orderlies, and mounted the corporal on a spare trooper.

A few minutes after this despatch-party had left Victoria Post, Captain Sandes, of my regiment, with his mounted servant and a pack-horse, also started with the intention of overtaking the little party and accompanying it to join the troops in the field. He did not, 
however, overtake Corporal Telemacus, and nothing more was then heard of Captain Sandes and his orderly. They must have fallen an easy prey to the Kafirs. Some time afterwards it was known that they were killed before they got to the Debe Flats.

As the column approached Block Drift, General Somerset moved on with the advance and took possession of the ford on the Chumie River, moved two of the Royal Artillery guns over the water, and taking up a good position, brought them into action on the masses of Kafirs which were still endeavouring to break the line of moving wagons. About two miles from Block Drift there is a conical bush-hill, which the Kafirs held in great force. As the wagon track passed at its base, and thence on to the Chumie ford through a 'thicket' of mimosa and other bush, there was a good deal of close fighting all along this space; and the rear was so hardly pressed that the guns had repeatedly to be brought into action and the Kafirs driven back by canister and shell. Two men of the 91st were shot close to the road while defending the wagons; and the Kafirs were so daring that they rushed in and were stripping the bodies when they were shot down and fell over the dead.

There was great delay, owing to the banks of the river being very steep and slippery, and each wagon stuck fast in turn, and had to be assisted out by soldiers. 
During all this time the fighting in the rear continued, Lieutenant Butler, 7th Dragoon Guards, with his men dismounted, holding the banks of the river below the Drift ; while Lieutenant Ougan, with the 91st Foot, held it above.

The ammunition of the rear-guard becoming expended, volunteers were called for from the cavalry, when both the 7th Dragoon Guards men and Cape Mounted Riflemen stepped to the front and proceeded on foot to replace the rear-guard.

One wagon had to be abandoned between the Conical Hill and the ford, owing to the oxen having been shot. This happened to be the hospital store wagon, and the Kafirs at once fell to plundering it, and not a few of them died on the spot from drinking bottles of poison. One Kafir was shot with a quantity of blister ointment in and about his mouth, their notion being that English medicine makes you strong.

To make a long story short, I may conclude by saying that the wagons were at last got over, the Kafirs beaten back, and a camp formed at Block Drift, taking advantage of the missionary buildings. 


\section{CHAPTER X.}

THE AFFAIR IN THE COWIE BUSH.

THE troops, after the first three days' fighting near Burns Hill and the Amatola, marched to Block Drift, (afterwards Fort Hare); and the Kafirs, having passed into the colony, were committing great ravages and depredations in Lower Albany; so much so, that the greater part of the troops had to march back vi $\hat{a}$ Graham's Town and follow up the enemy into Lower Albany. The camp was formed at McClucky's Farm, near Woodlands; and there had been several patrols to Lombard's Post, Dells Place, at Barville Park, Theopolis, Fairfax, and to the Cowie Mouth. On each of these occasions there were little 'scrimmages' with the Kafirs; but as one of the patrols were returning towards camp, about daylight in the morning, we heard firing in the direction of the camp; and as only a few men had been left to take care of the baggage-wagons, $\& c$., we proceeded at a rapid rate in the direction of the firing. This came from a wooded ravine which joined the Cowie Forest, not far from the camp, and 
arose through all the available men at camp having followed up a body of Kafirs who were seen passing within a mile of them just as day was breaking. This body of the enemy had come from the direction of Oliphants Hoek, and were making for the Cowie Bush, not knowing that a column of troops had followed them into Albany. The Kafirs were pursued, and had taken cover in this ravine, and were holding their own against the few men when we arrived. These men had cut off the enemy's escape into the forest by occupying a narrow part of the ravine below where the Kafirs were. The patrol consisted of a couple of squadrons of Cape Mounted Riflemen and a troop of the 7th Dragoon Guards, under Captain Hogge; and a couple of guns had also been brought up from the camp. Half the patrol were dismounted and sent into the bush, while the party from the camp held the ground below, thus preventing the escape of the Kafirs. Savages when hemmed in will fight with great determination, and we found it so on this occasion. They 'pre-occupied' the ground, and had selected their positions to great advantage. For instance, they held the bed of the river, with protecting banks in bends of it, that formed natural 'parapets.' We had to advance through thick bush, exposing the whole of our bodies, while only their heads would be above the banks; and moreover there was a tangled mass of 'waght-en-betjee,' ' or wait-a-bit' thorn, 
through which it was almost impossible to make our way; and while so doing we were under heavy fire. Several men had been knocked over; and I was hesitating whether we ought not to retire, as it was quite impossible to get at the Kafirs. Other men had been wounded on the right, and two were shot right and left of me, one a half-slave sort of fellow, named Isaac Isaac, who roared like a bull when hit. We were so close to the Kafirs, who held the river-banks, that the coarse-grained powder from the muzzles of their guns burnt my hands in several places. It was at this time that I suggested to old Joe Salis whether we had not better retire; but the fine old fellow, a true soldier to the backbone, said in his own drawling way, 'Noo, Bisset, we carn't retire; wee must stay here and die.' Now, this was rather severe on me, for I was Joe's senior officer and commanding the troop. At this particular time the wounded men were sent to the rear; and the General, who was with the supports, sounded the recall. This was only a few moments after Joe Salis had made the speech just quoted; and it was in a somewhat quicker tone he continued: 'Noo, Bisset, we can retire with honour.' And I can assure you we were not sorry to do it. But the party extending across the narrow part of the kloof was first reinforced and left in their position, to prevent the Kafirs from getting into the large forest. 
When we got back to the dear old General, who was always most considerate about his men, he exclaimed, ' () $\mathrm{h}$, this will never do, to have my men killed in the bush in this way-we must leave them alone.' But Armstrong and I both implored him not to do so, as in that case the Kafirs would look upon it as a victory to them, and it would give them more courage in their attacks on the Colony. We also pointed out how they were hemmed in, and how impossible it was for them to escape, if we only extended and advanced up the kloof, from where the men were left in double file, to guard against the escape of the enemy into the Cowie Bush. After a good deal of persuasion, the General said, ' $\mathrm{Oh}$, if you must go at them again, you may take volunteers ; I won't order my men into the bush to be killed.' This was all Armstrong and I wanted, for we both commanded squadrons, and the men were very fond of us; so we stepped to the front of our men and asked for volunteers to re-enter the bush and attack the enemy ; and it was most gratifying to see every man step to the front, eager to follow us. When the dear old General saw this he exclaimed a third time, "Oh, this will never dothis will never do. Tell off from the right and left of squadrons, and let the centre of threes stand fast.' Thus we got two-thirds of the men; and the remaining third, or centre of threes, were left to hold the horses. 
We proceeded to where the kloof was held by the party posted to prevent the enemy's retreat, and extending so as to take the whole breadth of the bush on the banks of the ravine, we advanced up it. A great many of the Kafirs must have been panicstruck, and were hiding in great ant-bear holes and caves. Those near the surface or at the entrance of the caves and holes could make no resistance; and I am sorry to say the men were so embittered against the enemy from the sight of their wounded companions, that they showed no mercy, and a promiscuous fire was poured into these places, which killed the Kafirs who were fighting as well as those who were unable from their position to fire outwards. No less than eight dead Kafirs were taken out of one of these holes.

I was leading my men up the bed of the river, most of it dry, but here and there we came upon pools of water. As we came to one of these the thin or wooden end of a bundle of assaigais floated up to the surface of the water; thus we knew that a Kafir or Kafirs must be there, and as we supposed under the water; so we remained some short time for him to come up to breathe; but no, there was no appearance. A yellow Hottentot next me, named Abraham Groenwald, went to the edge of the pool, to where there was the smallest possible tuft of grass, and stooping down he divided it with his hand, and there appeared the two nostrils of a great 
Kafir, not another part visible. He gave the spot a poke with the ramrod of his gun, and up jumped a great big greased Kafir, the water running off him as it would from a duck's back. Kafirs never give or take quarter, and this one immediately seized his assaigais, and was in the act of throwing one, when he was shot down, although I tried to prevent it. We then advanced, and about fifty yards ahead we came to a perfect stack of skin robes, blankets, and black sticks which they always carry to beat and drive cattle with. There was a pile some four or five feet high of these things, and we all knew that when they throw these articles aside they intend to fight. It was just at the spot which Joe Salis and I had been trying to get at, near the bank of the river, and where the channel gave a bend in the shape of a sickle or reaping-hook. I was leading, and was about to step across the bed of the river at the very bend, when a little 'tottie' of my troop, named Hendrick Dragonder, caught hold of me by the pouch-belt and pulled me back, saying, 'Vaght, bass,' or ' Wait, master.' At the same time he picked up one of the black sticks, and putting his forage-cap on the end of it, he held it across the bend of the river at the exact spot where I was going to step. Instantly twenty bullets riddled the cap and splintered the stick to pieces. The 'tottie' then said, 'Neuw, zur, gaat aan,' 'Now, master, go on.' We rushed across, and found about fifty Kafirs, actually 
standing in water up to their knees, just round the bend formed by the wash of the rivulet, nearly the whole of whom were shot before they could re-load, the remainder escaping into the bush. This was the same position they had held before the recall, but from the direction in which we were then approaching they were entirely protected by the high bank of the river, for nearly all rivers or water-wash have a high bank on one side and a flat or siope on the other.

As we continued to advance a curious thing happened. Some of the Kafirs had got into the tops of trees to hide themselves; one great fellow had got so far into the branches of a Kafir plum-tree, which is very brittle wood, that as we were passing under the tree the branch broke and this black warrior fell some forty or fifty feet, and did not require any further killing. By this time we were near the head of the ravine. Two guns had been brought up from the camp, with a troop of the 7th Dragoon Guards, under my old friend Captain Hogge, and several discharges of grape and canister had been fired into the bush, which caused a great panic. Captain Hogge's troop and these guns were on the opposite side of the kloof to that of the General and the Cape Mounted Riflemen. The residue of the Kafirs, or those who had not found secret cover, made a rush out of the wood just at the spot where the troop of the 7 th Dragoon Guards was; and although 
the troop charged, only three Kafirs were killed before they got into the next ravine adjoining the Cowie Bush. This was the end of the day's work, and the troops returned to camp at MacClucky's Farm. 


\section{CHAPTER XI.}

THE PASSAGE OF THE FISH RIVER.

During the early part of the Kafir War of 1846-7 Port Peddie was besieged by the enemy, and it became necessary to send a column of troops with a convoy of supplies to its relief. This force consisted of Cape Mounted Riflemen, under General Somerset; 7th Dragoon Guards, under Colonel Richardson; and detachments of Infantry, native Levies, Fingoes, \&c. They marched from Graham's 'Town, and halted the first night at Commetty's Drift, on the Fish River.

From Commetty's Drift to Breakfast Vley the road wound up the bush-covered heights of the Fish River. The troops marched early, and were allowed to proceed for some distance unmolested. There was a large convoy of wagons, which extended for some miles along this narrow road in the bush, and as the head of the column commenced to ascend the steep hill towards the first 'open' in the direction of Breakfast Vley, the advance-guard was attacked by a strong party of Kafirs, who held a ledge of rock in the bush, on the 
right of the advance. It was in such a position that they could not be outflanked or dislodged from it. Lieutenant Armstrong and myself dashed forward to support the advance-guard, with a troop of the Cape Mounted Rifles, followed by Major Gibson with a squadron of the 7th Dragoon Guards. Each party in succession had to fight its way through the rocky position held by the Kafirs. I was as near losing my life on this occasion as I ever was. After joining the advance-guard we were advancing, when a volley was fired by some Kafirs holding a second rocky ledge to the right, which knocked over several men and horses. I was carrying my double-barrelled gun at the advance, or rather with the butt of it on my left thigh. One ball, amongst others fired from the bush on the right, grazed my forehead and struck the right-hand barrel of my gun, entirely denting-in the metal. I felt the shock in my hand, and on looking down I saw my left thumb bleeding profusely. Many of the Kafir bullets were made of zinc, or pewter, stripped from the farmers' houses, and were of so hard a nature that when they struck anything they would break and fly in all directions. It thus happened that my hand became lacerated from the ball, which had struck the gun on a level with my head, and the splinters flew down and cut my thumb.

These Kafirs became so daring that they were 
rushing in upon us, and one was in the act of seizing my horse's bridle, when I shot him. Luckily I pulled the trigger of the left barrel, for up to that time I did not know that the right barrel had been flattened by the ball which had splintered and wounded my hand. As it was I shot the Kafir; but had I fired the right barrel the gun must have burst, as the ball could not have passed the flattened part. We, however, had to push on, as it was important to gain the top of the hill, where there was a small open space, and to hold it until relieved by the next advance.

Major Gibson was also warmly engaged at the same spot, and his first charger was shot dead under him. After we once gained the top of the hill the enemy deserted their stronghold, in order to take possession of other ground in the bush as we advanced.

From the top of the hill there was about three miles of thick bush to pass through, with only a narrow wagon-track cut through it. The Kafirs held this bush in considerable strength, but the column of cavalry forced their way through it on to the open ground beyond-the wagons being guarded by the infantry. As they entered this bush there was a general attack upon them along the whole line.

The fight became hottest in the middle of the bush; and the cavalry having formed up on the 'open' beyond, detachments were sent back on foot to support 
the infantry. Both Armstrong and myself had volunteered, and went back in this manner, accompanied by Captain Walpole, Royal Engineers, who obtained on this day the name of the 'English Lion.'

We reached the leading wagons at a moment when there was a complete block. Several of the oxen in the leading teams had been shot, and until they could be cut loose from their yoke-gear and pulled by main force out of the road no other wagons could pass. It was while doing this that Walpole's peculiar bravery became conspicuous. During all this time we were under fire from the Kafirs in the thick bush, without being able to see any of the blaek devils themselves. You had to take the oxen by the horns and tail, and so pull them by main strength out of the road.

Walpole was short-sighted, and carried a doublebarrelled pistol. The Kafirs would creep up and fire from the edge of the bush; Walpole would make a dash at the spot where the smoke was visible, stoop down, open the bush, and look for the Kafir. Probably at that moment another shot would he fired at him from the other side of the road, when he would bound over there, just as a lion bounds to where the ball.strikes, and the same search would take place'until another shot would be fired at him and the same thing repeated. Nothing reminded me more of a lion or a bulldog than this brave folly; for directly the Kafir fired 
he would rush back into the thicket, and you might as well look for a needle in a bundle of hay as for a Kafir in a forest.

It took several hours before we could successfully fight the whole of the wagons through this three miles of bush, and there was not a span of oxen that had not two or three of the team killed; but very few of the troops were shot. It was quite dark before we got all the wagons up and the camp formed for the night. This latter duty devolved on me, as staff-officer.

In Kafir wars a good deal depends on the judgment of taking up ground for a night-camp, because you are sure to be attacked and fired into before daylight. It so happened on this occasion. We formed on the slope of a hill, leaving the horizon of the slope a little beyond the line of sentries, so that they could see the enemy approach over it without being seen. On the other side of the lower end of the camp piquets were posted in such positions as entirely to command the camp. Only two or three men were wounded during this night-attack.

The next day's march was through comparatively open country; and the troops reached Fort Peddie without any more fighting, and so relieved that outpost, which had been surrounded by the enemy, and had had its supplies cut off for some time. 


\section{CHAPTER XII.}

THE BATTLE OF THE GUANGA.

AT the beginning of all wars at the Cape of Good Hope the Kafirs generally have it all their own way, from the fact that neither the Government nor the colonists are prepared for the outbreak; hence the enemy overrun, devastate, burn the homesteads, and carry off the flocks and herds throughout the frontier districts before sufficient force can be organised to stem the savage torrent-such was the case just previous to the battle $I$ am about to describe.

Several of the outposts had also been besieged by the enemy, and convoys of provisions sent to replenish them had been attacked, the escorts driven back, and in one case a large convoy of wagons had been captured by the Kafirs. In consequence of this state of things a strong column of troops, under the command of the gallant General Somerset, forced the passage of the Fish River Bush and relieved the outpost (Fort Peddie), which had up to that time been surrounded by the 
enemy and cut off from all communication with the rest of the colony.

At the same time two of the most powerful and warlike chiefs, Umhala and Seyolo, had massed their warriors on the Keiskama River, and a discussion arose between these two chiefs to the following effect. Seyolo, the most daring chief, at a council of war proposed that as they, the Kafirs, had so far beaten the white man in all encounters, their combined force should march the next day and attack an outpost situated on the Fish River-Trumpeter's Post-take the place by storm, possess themselves of the magazine, and thus obtain a supply of ammunition. Umhala, the more wary old chief, replied, "Yes Seyolo, your advice is good, but we cannot cross the open country between the Keiskama River and the Fish River Bush in the daytime-we should go by night.' Whereupon Seyolo exclaimed, 'Why, we have beaten the Englishman at all points and taken his cattle-we only require this ammunition to drive the English into the sea.' Again the old chief replied, 'Seyolo, do you know my war name?' 'Yes,' said the more impetuous Seyolo, 'you are called Umbozloo.' 'And do you know what that implies?' asked Umhala. 'Yes,' replied Seyolo, 'it means "wild cat.", 'It is well you know it,' answered Umhala. "We have just received intelligence that white troops are near us, and the "wild cat" does not 
roam by day; he prowls by night.' On this further words passed between the savage chiefs, and the word 'coward' was used; but the elder chief terminated the dialogue by saying he would not take umbrage at the epithet used by the more impetuous warrior--he, the 'wild cat,' would cross the open country that night in the dark, and wait for the brave man who might cross the 'open' in the daytime under the sun.

It thus happened that Umhala and his warriors crossed the open country between the Keiskama River and the Fish River bush during the night about the same time that a column of troops under General Somerset was moving from Fort Peddie up the belt of open country dividing the two rivers in search of the enemy.

As daylight broke we-for I was with the columncame upon the track or spoor, of this body of Kafirs at right angles with our own march, who must have passed over the open just before us. The trace showed a broad space of some twenty yards wide, with the grass trodden down and the dew dispersed from it. The General at once followed up this spoor, and as the sun rose we came suddenly upon a large mass of the enemy, who had fires lit, and were at their morning repast of dried flesh and parched Indian corn.

We were on a slope looking down on them at about 600 yards' distance, the Kafirs being in an open, sur- 
rounded by bush, with the Fish River jungle immediately in their rear.

Our forces consisted of two six pounders, two twelvepounder howitzers, and a rocket-tube; two squadrons of the 7th Dragoon Guards, two squadrons of the Cape Mounted Rifles, and detachments of Infantry of the Line-Levies, Fingoes, \&c. The cavalry and guns were in advance, and while the infantry were coming up the cavalry wheeled outwards, to allow the guns to pass to the front and come into action. Unfortunately it was the beginning of artillery practice. The shot and shell had been in store since the previous Kafir war of 1835 , and the fuses were all wrong. The first discharge of shell burst at the cannon's mouth, and the rocket exploded in the tube, while the round shot did little or no damage. The second discharge was equally ineffective, as the shells burst far beyond the then fast dispersing mass Kafirs.

By this time the infantry having come up were sent to the attack, and the cavalry was detached to the flanks to intercept or attack. The Kafirs fought desperately at first; but, as in all Kafir wars or bushfighting, when the savages find the tide of fortune going against them they disperse in a manner which no other troops in the world possess, they disappear like needles in straw. Detached knots, however, held their own in rocky fastnesses or in gullies protected 
by bush and natural banks, until they were eventually routed.

I myself was a staff-officer, and had been carrying orders to the detachments engaged. On one occasion, after the enemy had been driven into the bush beyond our reach, and were firing long shots at us (in two senses of the word), I was watching the result, when all at once I heard a wabbling, whizzing sound approaching me; and looking to my front, I saw a blue line in the air falling at an angle of about sixty degrees direct for my head. I had only just time (and I am not ashamed to say so) to bob on one side. A long piece of lead grazed my cheek and struck Major Walpole, of the Royal Engineers, who was standing immediately behind my horse. It sounded like a thud as it struck him on the thigh, tore out a piece of cloth about two inches long by one broad, and fell to the ground, but. did not enter the leg. The pain for the moment must have been excruciating, for it made the major jump about on one leg and grind his teeth.

The Kafirs firing these long shots were in almost inaccessible places; but a fine old soldier of my regiment (Colonel Donovan) rushed at one spot with only three or four men, and got amongst a lot of them before they could re-load; for they used powder-horns in those days and long junks of lead, or the legs of iron pots, and thus took a long time to load. On this occasion this brave 
athletic officer killed three warriors with his own sword, one of them being the chief, Zeto. Some others were killed and the remainder put to flight.

By, this time it was near twelve o'clock, and the desultory fighting nearly over; for natives have in this way the power of terminating a fight whenever it is going against them merely by dispersing in the bush. The enemy had, however, been beaten at all points, and the General sounded the recall, directing me at the same time to go back into the open in the direction of the Guanga River and take up ground for the troops to encamp upon, or rather to 'form ' upon, and get a meal, as they had been under arms since three o'clock in the morning, offering me his spare horse, my own being a little done up from galloping from one detachment to the other. This horse was a vicious chestnut brute, which the General rarely mounted himself; and I meution this because I shall have to allude to the horse again.

My old friend and companion through life, who was also on the staff (General J. Armstrong), said he would accompany me, and when we started the fresh horse commenced 'bucking' as a Cape horse only can buck, but by good luck I sat him, and to take it out of the beast we raced up a long slope; but when I got to the top the brute had got the bit between his teeth and no power on earth could hold him. He passed over the 
brow or ridge like a rocket, and was going headlong down the opposite slope, leading to the bank of the Guanga River, which I knew to be about twelve feet. deep. To avoid this, by dint of pulling I circled to the right round a rising contour of ground, and my astonishment may be imagined when I found myself running parallel with another large column of Kafirs entirely in the open, about a mile in length and twenty or thirty yards deep.

These Kafirs were equally astonished, for I heard the exclamations of ' Ogh!' ' Marwow!' meaning a wonder, an apparition. I no longer held my coursing steed, but by dint of the off rein and near spur I managed to run a circle and pulled up at the very head of the column of troops led by the gallant old General, to whom I reported what I had seen. He exclaimed 'Hurrah!' and drawing his sword, directed the cavalry, led by the 7th Dragoon Guards, the Royal Artillery next, and the Cape Mounted Rifles, which were in column of route, to form troops and squadrons; the infantry were following in loose order, or rather as they became formed after coming out of the bush.

The cavalry and guns advanced, as indicated, at the trot until we passed over the brow or knoll of ground before mentioned, when we came in full view of the column of Kafirs under Seyolo, the 'brave man' who would march over the open country in the daytime. 
It was a grand sight, and the general gave the word to the 7 th Dragoon Guards, who were in advance of the guns, to open out and allow the guns to trot through the space, come into action and fire two rounds; the ith Dragoon Guards forming line on each flank of the guns and charging; the Cape Mounted Rifles forming line in extended order and charging in succession to the 7 th Dragoon Guards.

The shot and shell did good execution, and the charge was the prettiest thing I have ever seen in real fighting. You might have placed a long table-cloth over each troop, they kept in such compact order; and the Cape Mounted Rifles went through the broken mass of Kafirs in one long line. But by this time the enemy had turned, broken and fled back over the open country in the direction of the Keiskama River. I could not resist the charge and passed through with the front, but could not hold my runaway horse, and therefore could not use my sword. The cavalry wheeled and came back re-charging the enemy, and when I did pull up I halted, and dismounted a bugler of my regiment, taking his horse and giving him mine; and after this we plunged pell-mell into the routed column of Kafirs.

It was strange how few Kafirs were killed in this charge. Though there was a clean sweep through them the width of each troop, and you saw them tumbling 
head over heels like ninepins, they nearly all got up again, and but few men were found the next day that were killed by sabre-cuts.

The gallant major of the Royal Engineers, who was hit in the early part of the day by a spent ball, also went through with the charge, and a Kafir seized his bridle and stabbed him with an assaigai, the blade entering at the under-lip, passing down the chin and throat, and entering at the collar-bone. The savage was trying to jag it into his heart, when he was killed; and strange to say this wound healed in a few weeks, while the one in the thigh took months. The blow of the first wound was so severe that it turned black, blue, and then green, and a mass of flesh the size of a small basin fell out, which had to be replaced by new material.

After the charge I returned my sword and un. strapped my double-barrelled gun, and for some six or seven miles the troops were mixed up with the running Kafirs, and a deadly slaughter ensued. I do not wish to boast-it is with much modesty and almost humiliation that I mention it now-but I fired away thirty rounds of ammunition that day, and did not fire at a Kafir that was above twenty yards' distance from me; I have the satisfaction to say that I was the only person who took a prisoner-I took three of them, one being a great chief, who turned out of much importance in a political point of view. 
In this mêlée or stream you had to look as much behind you as before, from being so mixed up with the enemy for miles. Seven extra notches were cut on the stock of my gun after that day, and I fired at no Kafir that was not in the act of firing at me or throwing an assaigai.

One fellow who had fired at and missed me, and at whom I had also fired two barrels, stood not ten yards from me to re-load, and I was doing the same on horseback, loading buth barrels against his one, but watching. for the time when he would prime, for I saw that he had a flint-lock musket. The Kafir, however, was ready first, before I had capped, but he omitted to prime. My friend Armstrong, who was on my right, also with his discharged gun, exclaimed, 'For God's sake make haste, or he will be ready first,' when the fellow put up his gun and snapped it in my face. I did not give him a second chance, for had it been fine powder the pan would have filled, and I should not have been here to tell the tale.

The next man I rode up to had a musket, and as I pulled up to shoot him he sat down, put his gun across his knees and his fingers in his ears, exclaiming, ' Fingoe, Fingoe!' I therefore jumped from my horse, took the gun from him, broke it in two, and handed the man over a prisoner to a soldier of the 7th Dragoon Guards. The Fingoes were serfs or servants of the Kafirs, and 
were coerced to join the enemy, although the main body of their tribes were our allies.

Passing on I came up to Lieutenant Boyce just in time; he was carrying a single-barrelled gun of mine, and had fired at a Kafir but missed him. The Kafir ran up and seized the bridle-rein of his horse, and was in the act of stabbing him with an assaigai when I prevented it.

Further on there was an herculean Kafir, with a bundle of assaigais, who, as I turned on him threw himself on his knees, held up his hands and said, 'Targho' (Mercy). I could not shoot him, but he is the first and only Kafir I ever knew that asked for mercy. I handed him over a prisoner to Sergeant Crawford, of my own regiment, and passed on with the stream.

After a while I came up with a chief, recognisable by his tiger-skin kaross (robe); he had only assaigais, of which they carry seven; he drew one and hurled it at me, and in return I missed him with both barrels; running a little way, he turned and threw another assaigai at me, which I parried with my bridle-arm, but it nevertheless passed through my jacket and underclothes, and gave me a severe cut in the arm. I again missed him, and he turned and ran.

At this time the ' recall' was sounding, but I was loth to let a chief escape ; and without re-loading I charged him. Now, my horse was a high-actioned old brute (a 
band-horse), and his knees struck the chief between the shoulders, bringing him down on to his hands and knees with great force. Before he could rise I was off my horse, and had seized him by the bundle of assaigais. Unfortunately I got hold of them in the middle, and he held them by one of his hands on the outside of each of mine, thereby having the leverage.

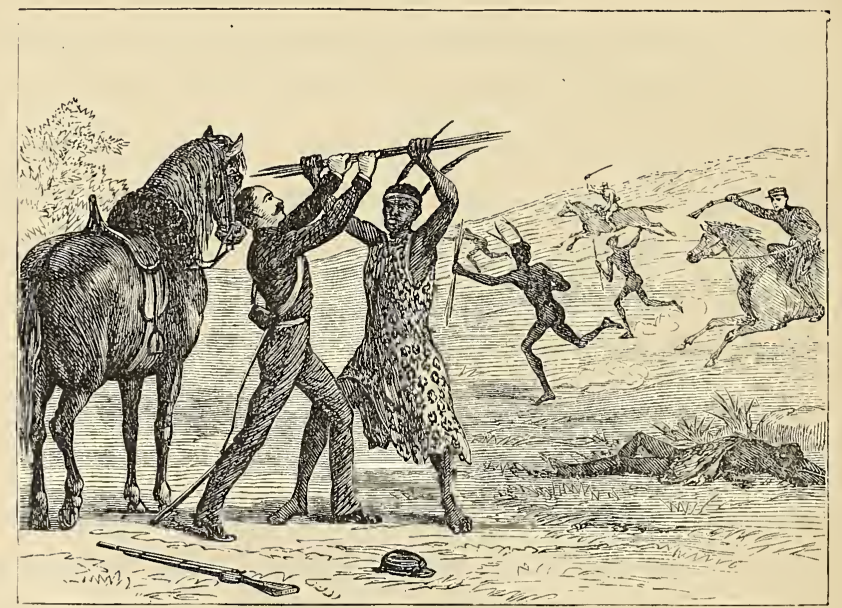

$\Lambda$ STRUGGLF FOR LIFE.

My horse was standing panting by my side, my gun was unloaded and upon the ground; other Kafirs were passing me in all directions. The chief was bleeding from the hands and knees, but kept up the struggle for life. At this moment Armstrong came to my assistance and threatened to blow the chief's brains out, 
whereupon he relinquished his hold and fell back in a faint.

I was very anxious to take this great chief back a prisoner myself, so I called a Cape Mounted Rifle soldier near me and directed him to go to the Guanga River, close by, and bring me his forage-cap full of water, intending to bring the old warrior to therewith. Now, there was a reach of water at this spot, known as the Seacow Hole, or pool where hippopotami used to hide; yet the man came back and said to me, 'Master, I cannot bring the water ; it is all blood.' This was from the number of wounded Kafirs who had jumped into this water to hide themselves, there being little or no cover in the open. However, by this time the chief had recovered from the faint, and I had got my horse's 'reim' round his neck, to lead him back a prisoner.

Un my way back, however, I was very near losing my prize. The Commander of the Forces had allowed a 6 free troop' to join the army; it was composed of farmers and others who had been burned out by the Kafirs. They equipped themselves and received no pay, but were allowed to retain all the cattle, \&c. which they captured. They were under little or no discipline, and were very bitter against the Kafirs.

The captain of this troop, seeing a prisoner in my hands, galloped up, and was in the act of shooting him, 
when I saved his life only by taking my oath that I would blow his (the captain's) brains out if he fired.

In extenuation I must, however, say that this man had much provocation; his stock had been all carried off, his homestead burned down, and his wife and children all murdered in cold blood by the Kafirs.

On my return to where the troops were mustering on Somerset Mount, the General was pleased to see one of the chiefs a prisoner, and when I reported having. made two other prisoners they were called for ; but, like 'spirits from the vast deep,' they would or rather could not come. I did not know the 7 th Dragoon soldier, and no man would confess to having received over a prisoner. Sergeant Crawford (Cape Mounted Rifles), whom I knew, however, came to the front and stated that as he was returning with the second prisoner two other Kafirs jumped out of a bush where they were hiding and tried to secure the prisoner, on which he shot him and one other Kafir.

The General sent me at once on express duty to carry a despatch with the account of the battle to his Excellency the Governor and Commander-in-Chief (Sir P. Maitland), then at Graham's Town, sixty miles off, which place I reached at midnight, and was back in camp at nine o'clock next morning.

During that night it transpired how the other 
prisoner had been disposed of. Round the camp-fires the battle was being fought over again, when the man confessed that he was not going to take a black blackguard to the rear while there was so much going on at the front. Alas! what is a man not capable of when his blood is up!

The chief turned out to be of much political importance in this way. It was the Frontier Kafirs under the great chief Sandilli-that is, Kafirland proper-who had made war on the Colony. Krilli, the paramount chief of all Kafirland, lived with the tribes beyond the Kie River, and he was known to be so far implicated that he had received the cattle of the chiefs who were at open war and also the plunder from the Colony; but it was not known that he had actually taken a part in the war or entered British territory.

The prisoner chief, however, convicted him; for he was at once recognised by Mr. Hoole, the Kafir interpreter, as one of Krilli's chief councillors, and was that day in command of a large contingent of the paramount chief's warriors.

Lieutenant Boyce was sent out the next day, and counted 270 dead warriors on the field of battle; but very many must have hid themselves and died who were not counted; and the number of wounded must have been great, for I myself saw many running with the stream covered with blood, and some with bullet- 
holes plugged up with grass. It was reported that more than 600 were killed.

Seyolo himself was badly wounded, and did not recover for many months, the Wild Cat only exclaiming 'Marwow!'

This was the only time the British troops ever caught the Kafirs really in the open ; and it will doubtless be long before the Kafirs give us another such npportunity of attacking them as was afforded at the Battle of the Guanga. 


\section{CHAPTER XIII.}

MURDER OF FIVE OFFICERS AT THE SOHOTA MOUNTAIN.

WHILE halted for a few days and in camp on the Koomgha, near the Kie River, in the war of 1846, six British officers left the camp without making it known to those who would have prevented their going, and proceeded to the Sohota Mountain, which overlooked the Kie River. This mountain was about four miles from the camp, was table-topped, and detached from the main ridge of land by a very narrow neck.

These officers started at about nine o'clock in the morning, with their guns, no doubt considering that they were of themselves a sufficient escort. One of them, Lieutenant Littlehales, 73rd Regiment, felt ill soon after leaving camp, and returned; and it was from him we learned later on where these officers had gone, with the intention of viewing the beautiful scenery of the Kie River.

These officers were not missed from carnp until evening; and when darkness closed in and the circum- 
stances were reported, all hope of their ever returning was abandoned.

I was at the time a staff officer, and the only one acquainted with that part of the country. Happily, I never forget a road that I have once been over; and if I ride or travel over a country once, and do not revisit it for ten years, I remember every hole and inequality of the ground as if it were but the day before, and the scene comes vividly to my mind as I approach the spot, even in the dark.

It so happened on this occasion, that my local knowledge was called into requisition; but, alas! it was not in the power of anyone to save the lives of the five wanderers. Their absence was reported to the General commanding, Sir George Berkeley, and at nine o'clock at night he ordered a column of troops to march out in search of them. His Excellency accompanied this column; and although I had not been over the same ground since the previous Kafir war of 1835 , I was able to lead the troops by a circuitous route along a ridge to within a hundred yards of where the bodies of these officers were found the next day. I remembered the ground perfectly, although I had not been there for over ten years. The mountain is separated from the winding ridge by what is called a 'neck,' that is, a narrow belt of land between two higher or falling grounds-in this case it was both; for this neck 
was a narrow gorge between the ridge, on which the troops halted in the night, and the Sohota Mountain, a table-topped hill, detached from it, with the heads of two wooded ravines running in opposite directions from the neck itself; thus it was not only a low neck between the two highlands, but it was also narrowed to a small space by these two ravines.

The column of troops, with which was his Excellency the Lieut.-General and head-quarters staff, reached the end of the ridge of comparatively open ground about midnight. I pointed out that in the dark we could proceed no farther, as the neck itself was bushy, and the road down the defile most intricate; we therefore fired several minute-guns; and as there was no response, the troops returned to camp, the General directing that another column of troops was to march at four o'clock in the morning to follow up the search and attack the enemy.

The next morning the General again accompanied the troops, and as staff officer I led them to the exact spot from which we had returned a few hours before. We reached the end of the first plateau, or ridge, as daylight broke, and on the tops of the trees in our immediate neighbourhood were seen the great carrion vultures of South Africa waiting only till the sun rose to pounce down on their prey. I knew at once what we had to expect, and led the column down the steep 
defile to the narrow ridge where we found the trunks of the five dead officers-I say the trunks, for their heads had been cut off and carried away to have diabolical processes of witchcraft and other 'devilly' perpetrated on them.

It was quite evident that these officers had been watched by the enemy the day before, and allowed to pass through this defile and ascend the table-topped mountain beyond it. The Kafirs must then have closed in on the neck and attacked the officers on the plateau above, for the spoor or trace of their horses showed that they had made a rush to get down from the mountain, and had been compelled to descend at a very steep part. Unfortunately, they were waylaid on the neck, and a struggle must have ensued there. The five bodies were quite near each other, and all had received more or less wounds, except the Doctor's, who did not appear to have received a single wound. His body was on a flat stone surface, quite naked, minus the head; and the quantity of blood which had flowed from him was equal to that from a bullock. It was a horrible sight.

The bodies were sent back to camp in charge of an escort, and the troops proceeded on to attack the Kafirs, who had assembled in large numbers on the peninsula towards the Kie River, with a ford across the river in their rear, through which they could retire when beaten and escape to the hills on the other side. The General 
and a small body-guard climbed to the top of Sohota Mountain, from which he had a good view of the operations. The ground was most intricate and bushy, and the Kafirs at first made a very determined stand. Troops were sent along on each side of the hill, and there was a good deal of bush-fighting; but the enemy made the most determined resistance on a long bushy spit of ground in the far bend of the river, and some reinforcements had to be sent on in support of the native troops, who were in advance. It was not until the ford-itself was 'covered' from the top of a precipice immediately below it, that the Kafirs gave way. You could see them carrying their wounded through the river, but they left a good many dead warriors on the field, while we had only three killed and about ten wounded. As usual the enemy were enabled to escape when they found the fight going against them, and there was nothing more then to be done; so the troops returned to camp.

The next day the five officers were buried at the Koomgha camp, the officer commanding reading the impressive burial service over them. The funeral was attended by all the officers in camp, the $73 \mathrm{rd}$ Regiment being the chief mourners.

As a tribute to the memory of Major Baker, I must mention that there was not a dry eye amongst the men of his company, he was so universally beloved by them. 
I have seen him on the line of march dismount and give his own horse for tired men to ride upon; nor would he ever allow his own tent to be pitched until he had seen his men under shelter; and he would then go and secure a hole of water or make a small reservoir of it for the men-generally a scarce article in camp, from the number of draft oxen that go into and muddy the pool.

The bodies of these officers were afterwards disinterred and removed to King William's Town, under the authority of the Bishop. They are now buried in the church at that station, to which Lady Eiizabeth Baker contributed a large sum of money.

After the war a gold watch which belonged to the Doctor was recovered from the Kafirs by Mr. John Crouch and sent home to his family. An assaigai, evidently thrown at the Doctor, had struck this doublecase hunting-watch in the very centre, for it had penetrated through both cases and into the works, which had stopped at that moment, showing that they were attacked at two o'clock in the day.

The five officers whose terrible fate I have been relating were Major Baker, Lieutenant Faunt, Ensign Burnup, Surgeon Campbell, 73rd Regiment; AssistantSurgeon Lock, 7th Dragoon Guards; and the officer who turned back after starting was Lieutenant Littlehales, a cousin of Major Baker. 
These five officers fell not far from the spot where three other gallant officers were killed in the same war, about a year previously, viz., Lieutenant Chetwynd, Captain Gibson, Rifle Brigade; and Assistant Surgeon Howell. These officers were cut off from their men on a similar table-topped mountain. They were buried on the heights, on the east bank of the Kie River, inside a Kafir hut. The hut was then set on fire and burnt, to hide the grave from the Kafirs, who were thus prevented from either disinterring or mutilating the bodies.

It is remarkable that an officer also on this occasion escaped by chance. Captain Cartwright, Rifle Brigade, had been detailed for this duty. On the patrol parading to start he felt ill, and Lieutenant Chetwynd, who also was a cousin of Cartwright's, took his place and fell.

Poor Cartwright was afterwards killed at the battle of Inkermann. 


\section{CHAPTER XIV.}

THE AFFAIR OF THE GOOLAH HEIGHTS.

In May 1847, while Deputy Assistant QuartermasterGeneral at the head-quarters camp at the Goolah Heights, in British Kaffraria, I had occasion to go up ' the Buffalo Line,' to examine the Quartermaster General's stores at the other camps. Sir George Berkeley, in chief command on the frontier, was at this time at Fort Peddie. Sir H. Somerset was in command of the camp on the Goolah Heights, and Sir George Bullen in command of another camp at King William's Town; with two intermediate posts of communication between, viz., one at Needs Camp, and the other at Mount Coke.

General Somerset had gone to head-quarters to consult with the Commander of the Forces ; and Colonel Armstrong was in temporary command of General Somerset's force.

The evening before I was starting for King William's Town we received intelligence that Needs Camp required provisions; and as I was taking a small 
escort with me up the 'Line' two mule-wagons were detailed to accompany me, with a supply of biscuit for that post. The escort consisted of one sergeant (Crawford) and ten men of the Cape Mounted Rifles, the two wagons being in charge of John Crouch, or 'old John Crouch,' as we used to call him. He was sometimes a conductor of wagons, and sometimes guide. Another celebrated character volunteered to accompany us-no less a person than Walter Currie, afterwards the well-known Sir Walter.

We started early one morning, and had proceeded about eight miles along the Goolah ridge, the road or track winding between clumps of forest-trees or round the heads of ravines leading down from the ridge to the low lands on each side of us. We were riding leisurely along, with an advance and rear guard, knowing that near this spot a strong party of Dutch-part of the field force called a 'commando'-had been attacked by an ambush of Kafirs only a few days before, when three of the party were killed, viz., two Pexters and a Ferriera. It was a most discreditable affair. Commandant Muller had about eighty men under his command, and was proceeding to form a camp of communication between Needs Camp and Mount Coke. They must have been marching without advance-guard or flankers (side-videttes), when they were suddenly fired upon from bush and rocks. The three men whom I have 
alluded to immediately jumped from their horses, to make a standing fight of it; but, strange to say, the remainder rode away, and these three men were surrounded by the Kafirs before they could remount. They, however, made the best fight they could, and retired on foot towards the camp they had left, until they were overpowered and killed. It is not known what number of Kafirs fell, as the savages carry off their unstiffened dead and wounded. I say unstiffened dead, because the Kafirs will not touch a really dead body-that is to say, one that has become rigid. So long as the body is warm and the limbs supple they have no dread; but when the body is once cold they will not touch it. For this reason the sick are often carried out of their huts long before they are dead and left to die in their last resting-place.

I have somewhat diverged from my story. But to proceed. As we approached this spot-ever afterwards known as Muller's Bush-Currie advised us all to look to our guns and see that the caps and priming were dry-for we all, officers and men, carried doublebarrelled guns in those days. My caps were the only suspicious ones. The gun had been loaded for some days, and the caps very soon corrode from the dew at night. My friend Currie actually scraped the caps off my gun with his knife, pressed a little fine powder into the nipples, and re-capped the gun. We had 
proceeded about a mile after this, and had entered into a long narrow glade, with high forests on each side of us, varying from fifty to eighty yards from the wagontrack, this open being interspersed with thorn-trees (mimosa) and rocks. This narrow ridge extended for about another mile, and it was quite impossible to see a single yard into the thick bush on each side. The Kafirs very wisely allowed us to pass some distance into this narrow glade, when suddenly a strong party of them extended across the open behind us and at the same time commenced to fire all along the edge of the forest on both sides. There was no alternative but to draw the two wagons up, dismount our party, get under cover of rocks and bush, and so endeavour to beat off the enemy. During all this time naked black fellows were seen running along the edge of the bush to our front, towards the identical spot where Muller had been attacked; and it was amusing to hear their jeering cries, such as ' You must look at the sun, for it is the last time you will see it.' 'You are like a mouse in a calabash: you have got into it, but you cannot get out.' By this time we had pretty well beaten off the Kaffirs in our rear, except those holding the ground, like us, from behind rocks; and I had ordered the men to mount, that we might push on. One horse was hit while the trooper was mounting, and swerving threw the rider, upon which there was a great shout of exultation. 
John Crouch's horse also became restive, and Currie had to hold him while 'old John,' who was lame, mounted. During this time we were all more or less exposed; but knowing the narrow defile we should have to pass through, I ordered the wagons to advance. Just before we came to the spot where I knew the hot part of the attack would be made the road slightly diverged to the right, and the view from the rocks already occupied by the Kafirs was hidden by some large mimosa-trees. At this spot, and before turning the corner, I halted the wagons, leaving Sergeant Crawford and five men with them. The Kafirs were holding the ground on the right of the road in considerable force. Immediately opposite to where they were the ground rose to a sort of hillock, dotted over with rocks, and the road ran between this hillock and the rocks held by them, which also adjoined the high forest wood, falling in one continued extent towards the Buffalo River. Currie, John Crouch, and myself, with the other five men, diverged from the road to the left, and so got out of view from the cover of the hillock. We at once dismounted, handed our horses to one man, and ran up to the mound, each taking advantage of a rock for cover. An extraordinary scene at once met our eyes. There were about eighty black fellows, with guns, all 'lying on' or taking aim over rockss, their guns pointing to the road 
just where it came into view from behind the thorntrees. They never dreamed that we were exactly opposite, under cover of rocks, and within forty yards of them; and it was not until we discharged our one barrel at them, knocking over several, that they were aware of our manœuvre. Their astonishment was so great that they turned their guns to the right, and, almost without taking aim, fired a volley at us. At this moment I shouted to Sergeant Crawford to push the wagons through, which had to pass slightly in a hollow between the Kafirs and ourselves; but as very few of the enemy's guns were held in reserve or reloaded in time to fire on them the men escaped unhurt, and only three or four of the mules were wounded. After passing through the narrow part the wagons turned off the road to our side, and also got protected by higher ground. It is well that this precaution had been taken, for had we kept the road and come into view round the thorn-trees very few of us would have been left alive to tell the tale. About eighty guns were bearing on the spot at forty yards' distance; but as it turned out it was the most absurd thing I ever saw. The leaders and drivers of these mule-wagons were Malays, from Cape Town, with large umbrella-shaped straw hats on. They usually sit on the box in front of the wagon, one man holding the reins and guiding the six or eight mules, and the 
other, with a long whip fastened to the taper end of a long bamboo, whipping them on. But on this occasion both of them were on the ground and running alongside the wagon, one opposite its front and the other opposite its hind wheel, with nothing but the monster hat to be seen above the ground, looking more like monkeys or moving mushrooms than anything else. It is astonishing how they contrived to guide and drive the mules in this position.

Unfortunately this did not end our dilemma. The Kafirs were strong and confident; we were weak and with but little ammunition-thirty rounds per manand each force held their position, firing shot for shot from behind the rocks. Needs Camp was within sight of us, about three miles distant. The post consisted of a company of the Rifle Brigade and a despatch-party of twenty Cape Mounted Rifles. They could see us in action with the enemy, but their horses were generally turned out to graze, and it took some time before they could be called in and saddled. We heard the 'assembly' sound, then ' horses in' and ' boot and saddle;' but in our situation it seemed an age before they were ready to come to our assistance; and it reminded one of Sister Anne, in the nursery-tale of 'Bluebeard.' All this time we were firing shot for shot, and our ammunition was all but expended. Some Kafirs had got into the forest-trees, and were 'potting' at us from 
above. Their position gave us this advantage, that they could also see the preparations making at Needs Camp fur reinforcing us. All at once we heard a great commotion and calling to one another amongst the Kafirs, and I heard the repeated name of 'Tandanna,' which I took down in my pocket-book. Thinking it was preparatory for a rush upon us, we all held both our barrels loaded and in reserve; but it was with quite a different motive. The Kafirs in the trees could see much better than we could, and they did see the Cape Mounted Rifles racing along the road from Needs Camp at the top of their speed. Soon we saw them approach, although in no order, save the fastest horses to the front; and then Currie, Crouch, and I rose, with our party, charging on foot across the space dividing our rocks from those held by the Kafirs. The whole space was only about fifty yards, with the road in a slight hollow between us; and the rest of it was covered with long grass, stones, holes, and other impediments. We rushed across this space like mad, and down went Currie. Only a few shots were then being fired at us, but the idea passed through my mind that he was killed; but almost before the thought he was alongside me again, and we just got up to the tail of the Kafirs as they were rushing in the opposite direction from us. We found ourselves amongst the dead and dying, or rather amongst the dead, for nearly every Kafir we 
had hit was struck in the eye or through the head, the head and shoulders alone being exposed from behind the rocks while taking aim at us. Seven great Kafirs lay dead at our feet, two others were just alive. We followed the mass of the retreating enemy some distance into the bush. There was a good deal of blood from wounded men carried to the rear, and we could hear the retreating enemy breaking through the bushes like a herd of buffaloes.

We then returned to examine our respective positions. I had taken cover behind a not very large rock, with a second rock on the top of it, with a wedgeshaped chink horizontally between the two. It was through this chink that I was enabled to take deliberate aim; but mine being a smooth-bore gun, I give the palm of those killed to my friend Currie, who was one of the best rifle-shots of the day. Strange to say, I had placed my forage-cap, with a silver-bound peak, on another stone about a yard to my right, and this took off the fire from me. Fully five-and-twenty shots hit this stone, and the fine splinters from the rock often struck me on the face and hands, but not one of the bullets hit the cap. This rock is still seen by passers-by almost covered with lead in star-shaped forms from the flattened balls. General Sir H. Somerset happened to arrive on the ground soon after the action, and he sent on my report of the affair to the 
CHAP. XIV. THE AFFAIR OF THE GOOLAH HEIGHTS. 115

General commanding, and I received in reply the thanks of the Commander of the Forces. A strong patrol was despatched in pursuit of the enemy; and although they did not overtake the Kafirs, they found quantities of blood where the wounded had stopped to rest. 


\section{CHAPTER XV.}

THE BEEKA MOUTH.

DuRING the Kafir War of 1846-7 such a drought prevailed throughout the frontier districts of the Cape of Good Hope and in Kafirland, where operations were being carried on against the Kafirs, that the Governor and Commander-in-Chief, Sir P. Maitland, was compelled to fall back with the troops and form a camp on the coast at Waterloo Bay, near the mouth of the Fish River. This was done in order to establish a landingplace on the coast for supplies, instead of having them carried overland from Port Elizabeth, a distance of about 150 miles, to form a base for renewed operations, and also to save the few remaining draft-oxen with the army, as it was almost the only portion of the Colony where there was still any herbage or grass left.

'Where the carcass is there will the eagles be gathered together,' and so is it with the Kafirs. For the sake of plunder they follow all large camps, and live by stealing and capturing stray and ill-guarded cattle. The draft and slaughter cattle had to pasture some 
distance from the camp to obtain food; but cattleguards and pickets were invariably posted.

One day an alarm arose in camp that the cattleguard had been attacked by the enemy, several of the herdsmen killed, and a large number of draft-oxen carried off by the enemy.

In consequence of the scarcity of forage the horses of both the Cape Mounted Rifles and 7 th Dragoon Guards were, in the daytime, knee-haltered and turned out to graze; but his Excellency invariably kept a small body-escort of cavalry ready-saddled in camp. On the alarm or report of the attack reaching camp, and while a patrol was being formed to follow up the enemy, Sir P. Maitland and his personal staff, consisting of Colonel Cloete, Deputy QuartermasterGeneral, myself, and one or two others, at once mounted and with the body-guard of about twelve men (Cape Mounted Rifles and 7th Dragoon Guards), followed up the Kafirs. I knew the country well, and was aware that the Kafirs must either pass inland with the cattle for some distance before they could cross the several rivers that enter the sea between the Fish and Keiskama Rivers, or else they must at once turn down to the coast and cross the rivers on the beach at their mouths, where there is a bar, and generally shallow water. I therefore led the Governor and escort at a gallop to the mouth of the first river, the Dart, and 
there, sure enough, the Kafirs had crossed, and the spoor, or trace, showed plainly along the beach to the next river, the Wolf River, a distance of about six miles-the cattle had evidently been driven along here at a great pace. The tide being in, the sands were heavy, and the horses became somewhat 'blown' before we reached the Wolf River. The Kafirs must have been in the same plight, for after crossing its mouth they turned inland with the cattle, passing through a bush of about half a mile in extent. This bush extended all along the coast, between the open downs or grass country and the sandhills and open beach. After passing through this bush the Kafirs continued eastward along the downs, but skirting the bush; and although the country was undulating it was more easy to drive the cattle over from being open.

'The escort-horses with the Governor being rather 'blown,' I started ahead with a single orderly through the bush-path, and came on the spoor, or trace, of the cattle in the direction of the Beeka River. After galloping about three miles and 'rising' a brow in some undulating ground, I came suddenly in sight of the Kafirs, with the cattle, about 200 yards ahead of me. They appeared to have no knowledge of the pursuit, and were driving the cattle at a sort of hand-trot. I immediately drew back over the brow, without the enemy having seen me; and, from my recollections of a 
vidette's duty, commenced circling to the right, directing my orderly to follow me in the circle. By this time the Governor and escort made their appearance through the bush-path; and Colonel Cloete, seeing me, exclaimed, 'Look, look! there is a Kafir chasing Bisset.' But the old General said, 'No, Cloete, he is circling to the right; the enemy is in front, and at once came tearing down to me. I reported what had happened, and added that if we galloped hard we should overtake the enemy before they rounded the mouth of the next or Beeka River. This river is the largest of all the rivers between the Fish and Keiskama; and moreover, from where the Kafirs would strike the bank of it, at the commencement of the bush, there is a long stretch of narrow beach, between the water, which is deep, and the sandhills, which are covered with thick bush. This narrow beach varies from fifty to twenty yards in width, and is about a mile in length, before reaching the mouth of the river, where alone the water is fordable.

I was very well mounted on an old favourite horse called Rattler, and rode forward with about half of the fastest of the escort-horses. We were about 100 yards ahead of the Governor and the rest of the party; and as we dropped down the bank of the river on to the narrow beach, where the direction turned suddenly to the right, we saw the Kafirs, about fifty in number, two 
or three hundred yards ahead, driving the cattle as fast as they could along the deep sands. I called the six or eight men together, and, standing in my stirrups, I said in a low voice to the men 'Charge!' and we raced on until we came to within fifty yards of the Kafirs and cattle. Up to this time they had never once looked back, being apparently quite unaware of our near approach; and the sand was so deep and soft that there was not the least noise from the horses' hoofs. I saw that most of the Kafirs were armed with guns, the remainder with assaigais, and I felt that we should be amongst them at a disadvantage, because half the effect of a charge is caused by a panic to the other side. I therefore again rose in my stirrups and shouted a great shout, and with that we were upon them. Our horses were perfectly pumped; and as I pulled up suddenly to shoot a Kafir who was taking aim at me, two of the seven troopers also pulled up so suddenly in the deep sand that they flew over their horses' heads like shuttlecocks. Each of these men shot a Kafir before they rose from their sitting position. My opponent could not stand the two barrels that were staring him in the face; he missed me, and as he turned got the contents of one barrel, which tumbled him over. Three other fellows were shot before they got up the sandhills and into the bush.

The firing made the cattle 'spurt' to the front along 
the narrow beach, and I and two men had to gallop through the water (up to our horses' girths) to get in front of them; and here we found a nearly equal number of Kafirs, who were running, as is their custom, in front of the cattle. These warriors were chiefly armed with assaigais, which they began to hurl at us. One great fellow drew a second spear, and as he raised his arm to throw it at me I let fly my second barrel, putting the contents into his left breast, and he immediately subsided. This firing checked the cattle, and we turned and drove them back. As the rest of the Kafirs escaped into the bush I noticed that the Kafir whom I last shot was carrying one of their knapsacks over his shoulder, which bulged out and appeared to contain something unusual. I therefore jumped from my horse and slipped this sack or bag from off his neck and placed it over my own shoulder. The poor fellow was still breathing, for both these men were shot with partridge-shot. I had lent my gun the day before to Major Burnaby, R.A., to shoot partridges near the camp, and had quite forgotten to reload with ball in the hurry of leaving the camp.

The Governor dropped duwn the bank of the river on to the level beach just in time to see the charge, and was highly pleased at the success of the pursuit; and with the additional aid we soon got the cattle back on to the open country. 
I urged on his Excellency that we should not delay in getting them past the bush-path at the Wolf River, that our party was very small, and that I had seen over fifty Kafirs with guns, besides those with assaigais; and that, seeing our small numbers, they would be sure to head us at the bush-path.

Dear old Sir Peregrine said, 'Oh, no, Bisset, you have taught them such a lesson that they will not venture to come near our camp again.'

The words were scarcely out of his mouth when we heard 'Ping, ping, ping, ping!' and saw the dust flying up all about us, and the white smoke at the edge of the bush, not one hundred yards from where we were standing. The General said, 'You are right, Bisset; and I should not like to be shot by a Kafir from behind a bush after going through Waterloo.' Putting spurs to our horses, we hurried the cattle along as fast as we could. Before we reached the narrow bush-path at the next river we were met by a strong force of cavalry, which had 'called the horses in,' saddled, and followed as fast as they could; and before long we also met a strong party of infantry from the camp.

As we had now more leisure I began to examine my knapsack-this means the skin of a deer skinned whole, and open only at the hind legs. The skins are dressed and made as soft as a glove, and are very convenient for carrying anything. Mine, on this occasion, 
contained to my surprise several pieces of real English plate, in the shape of an old-fashioned silver teapot, a snuffer-tray, two silver forks, a tablespoon and two teaspoons, besides the usual tinder-box, tobacco and pipe, and some other trifling articles. There was no mark or crest on the silver; and although I advertised for the owner no person has ever claimed the articles.

The Kafirs were no doubt on a return foray from the Colony, where they had probably murdered a whole family at some homestead, and plundered the house before burning it. In many instances not a soul was left out of whole families that were fallen upon in isolated positions. However, this party paid dearly for their foray. 


\section{CHAPTER XVI.}

THE SURRENDER OF SANDILLI- $18+7$.

TowarDs the termination of the war the Kafirs were so hotly pressed by the columns of troops operating against them in the Amatolas that Sandilli, the paramount chief of Kafirland, was compelled to surrender. I was at this time chief staff-officer to General Sir George Buller's division of troops, and our camp was situated in the Keiskama Hoek. Patrols had been hunting up the Kafirs both by day and night, when all at once Sandilli sent in to say that if I were despatched to a certain spot he (having confidence in me) would surrender to Her Majesty's Government. Accordingly at daylight the next morning $I$ was sent to the place indicated, accompanied by a single orderly and an interpreter. This spot was at a large thorn-tree (mimosa), on an 'open' before crossing the stream leading over the brow to the entrance of the Boomah Pass, and nearly opposite to the conical hill at the entrance of Oliver's Hoek. As the sun rose I saw a body of mounted Kafirs approaching me at a rapid rate by the 
bridle-path at the base of the conical hill from the direction of Oliver's Hoek. This turned out to be Sandilli, with eighty of his chief councillors and head men ; and he told me he had come to surrender himself to Her Majesty's Government with a view to obtain peace. I replied that his surrender must be unconditional. $\mathrm{He}$ tried to discuss the question with me. I again replied that I could make no conditions; and that the only thing I was authorised to guarantee was his personal life. I had to repeat this in Dutch to the interpreter, who could not speak English. I did so in the word 'Personlyk Lieve,' which was also repeated by my orderly (a soldier of the Cape Mounted Rifles, named Lucas), for he spoke both Dutch and Kafir. I mention this particularly, because a question subsequently arose through Sandilli some time afterwards claiming his liberty, on the supposition that he was promised his 'personal liberty,' not life.

I then brought this great chief and eighty of his chief councillors into camp. His retinue included his half-brother, $\mathrm{X}_{0-\mathrm{xo}}$, and most of the petty chiefs of Kafirland. This surrender was the most important event of the war, and Sir George Buller and the whole camp were much rejoiced to see this King of Kafirland, who had maintained a war with England for over two years, brought into camp by a single soldier. Sir George Berkeley was at the time General Commanding- 
in-Chief, and was with the head-quarters of the army at King William's Town; while his Excellency Sir H. Pottinger, the Governor, was at Graham's Town. After bringing Sandilli into camp, and after a short ' palaver,' Sir George Buller sent me in charge of the great chief at once to King William's Town, which place I reached before eleven o'clock. His Excellency Sir George Berkeley was highly delighted with the surrender of the chief, and asked me if I were able to proceed on to Graham's Town with a despatch containing a report of the circumstance, and requesting instructions from the Governor as to the disposal of the prisoner. I was quite prepared, and started at once with an open order for a relay of troop-horses from post to post en route. Major Hogge, 7th Dragoon Guards, accompanied me on this journey, and it is wonderful how his single horse kept up and performed the distance. We reached Graham's Town a little after nine o'clock, just as Sir H. Pottinger had finished dinner. Sir Henry requested me to state when I would be ready to return to King William's Town with his reply despatches. I replied, 'In one hour.' The despatch was not, however, ready until eleven o'clock, when I started, and was back at head-quarters at nine o'clock next morning, making a distance of over 200 miles in little more than twentyfour hours. But this did not terminate my ride. The despatch to Sir George Berkeley directed that Sandilli 
should at once be sent a prisoner to Graham's Town, and I was selected to command the escort and to take him thither. The escort consisted of a detachment of Cape Mounted Rifles and an equal number of the 7th Dragoon Guards, under Lieutenant Petre. Sandilli was allowed to take two followers, and we proceeded that day to Fort Peddie, thirty-two miles, en route to Graham's Town. Sandilli was secured in a room in the fort, and I slept at the door. The next morning we started at sunrise ; and instead of proceeding vîa Trumpeter's Drift and through the Fish River bush, where I considered it possible that an ambush-party of Kafirs might attempt to rescue their chief, I proceeded through the open country to the mouth of the Fish River, which we crossed in a punt, and thence on that night to Cawoods Post, where we again halted, having ridden thirtyseven miles. The next day (Sunday) I reached Graham's Town at two in the afternoon, and handed Sandilli over a prisoner to the military authorities there. 


\section{CHAPTER XVII.}

\section{THE BOOMAH PASS- 1850 .}

In December 1850 the Kafir War broke out that lasted until 1853. British Kaffraria had been held by military occupation from the termination of the previous war (1847). The military head-quarters were established at King William's Town; and several minor posts were occupied in different parts of the country, to keep the Kafirs in subjection.

The Kafir chiefs, however, formed a combination to throw off the white man's supervision of their country, and committed several overt acts, with the intention of bringing on a war. Cattle were stolen from the Colony; and although traced into Kafirland and to the marauders' kraals the chiefs refused either to give up the beasts or to surrender the thieves. Wagons were also stopped upon the high roads and plundered, and in some instances the leaders and drivers killed.

General, then Colonel, Mackinnon, commanded in Kaffraria, and was also chief civil governor of the province. This officer's rule in Kaffraria had been most temperate and just towards the Kafirs, and his word 
was like the laws of the Medes and Persians. Sir Harry Smith was at the time Governor and Commanderin-Chief in the colony of the Cape of Good Hope.

The rebelilious and warlike indications of the Kafirs were reported to him at Cape Town. He was, however, at first incredulous of their intentions, and in reply to a petition from the frontier farmers quoted the non-existence of certain indications which always precede Kafir wars. He was therefore much surprised afterwards to find that the very circumstances on the absence of which he relied were actually at that moment taking place on the frontier.

Sandilli, the paramount chief of all Kafirland proper, was at the head of the war party; and seeing that war was inevitable, Colonel Mackinnon ordered a column of troops to march from King William's Town to Fort Cox, where a camp was formed. Each of the two great chiefs of Kaffraria had a Resident Commissioner residing at their great kraal; thus, Mr. Charles Brownlee resided with Sandilli at Burns Hill, near Fort Cox ; whilst Colonel Maclean was Umhala's, or the Tzlambie Commissioner, residing at Fort Murray. Sandilli's tribes were called the Gaikas.

When the troops were collected at Fort Cox a demand was made on Sandilli-through Commissioner Brownlee, for restitution of the property stolen from the Colony, and compensation for the murder of British 
subjects. These demands, however, were treated with contempt by all the native chiefs. At about this stage of affairs the Governor, Sir Harry Smith, arrived on the frontier from Cape Town, and at once proceeded to the head-quarters of the troops at Fort Cox. Several days' negotiations followed with the Gaika chiefs and head men of the tribes; but Sandilli remained contumacious, and the Governor came to the decision to depose him from his royal chieftainship, and to appoint Mr. Brownlee Regent to the Gaika tribes.

It may not, perhaps, be right for me to criticise these measures, but Sir Harry made a great mistake in this decision; and Mr. Brownlee, who was his adviser, ought to have known better. He was the son of a missionary, and had grown up amongst the Kafirs. He should therefore have been aware that the feeling of loyalty to their hereditary chiefs and the clanship of the Kafirs are quite as strong as those of the Scottish Highlanders to their chieftains. However, the error once committed, troops were ordered to march into the Amatola Mountains, with a view to capture or take Sandilli prisoner. It was the old story of putting salt on a bird's tail, and the same results were about to take place.

One column of troops was despatched from King William's Town to the sources of the Kaboosie River, east of the Amatola Mountains, with the object of 
intercepting the chief should he endeavour to escape over the Kie; this column consisted of cavalry (Cape Mounted Rifles) and infantry, under the command of Colonel Eyre, 73rd Regiment.

Another column, consisting of Cape Mounted Rifles, armed Kafir police, and infantry detachments from several regiments-in all about seven hundred men, under the command of Colonel Mackinnon-marched from the camp at Fort Cox direct into the Amatola Mountains, in the direction of the Keiskama Hoek, with the view of taking Sandilli prisoner.

My nominal appointment in British Kaffraria up to the time of the breaking out of the war was that of major of brigade, but from the moment the troops took the field I became chief staff-officer, and the whole of the duties of the Adjutant-General's and Quartermaster-General's departments devolved upon me.

The column under Colonel Mackinnon marched from the camp at Fort Cox at daylight on the morning of December 24, 1850, and after passing Burns Hill mission station wound up the valley of the Keiskama, and, crossing that river three times, halted for breakfast on its right bank near the junction of the Wolf River. The whole distance was mostly through dense bush, with no roads except cattle-tracks or footpaths made by the natives, and with rugged mountains and dense forests all round us. 
While we were halted in a comparatively open space for breakfast I saw large masses of Kafirs collecting on all the hills, while only one solitary Kafir came into camp, nominally to offer a basket of milk for sale, but in reality to 'spy out the land' and take note of our strength, \&c. As chief staff-officer with this column, and from having been in or rather through the two previous Kafir wars of 1835 and 1846-7, and from knowing the ' nature of the beast,' I pointed out these hostile indications to my chief. I also told him that a little farther on we would have to defile through the Boomah Pass, a most formidable position, where the troops could only pass in single or Indian file, and that the path was intersected by great rocks and boulders that had fallen from the precipice overhanging the footpath. Colonel Mackinnon, I fear, was imbued with the idea that the Kafirs did not intend to fight. After a short halt the troops fell in, and continued the march in the direction of the Keiskama Hoek in the following order : the Kafir police in front, then the Cape Mounted Rifles, followed by the Infantry of the Line, consisting of detachments of the 6th, 45th, and 73rd Regiments. There were also pack-horses with spare ammunition, medisal panniers, \&c., \&c., and a rear-guard. Soon after leaving the halting-ground the column had to cross the Wolf River, with a very bad ford of slippery rocks, which caused several breaks in the column; and about 


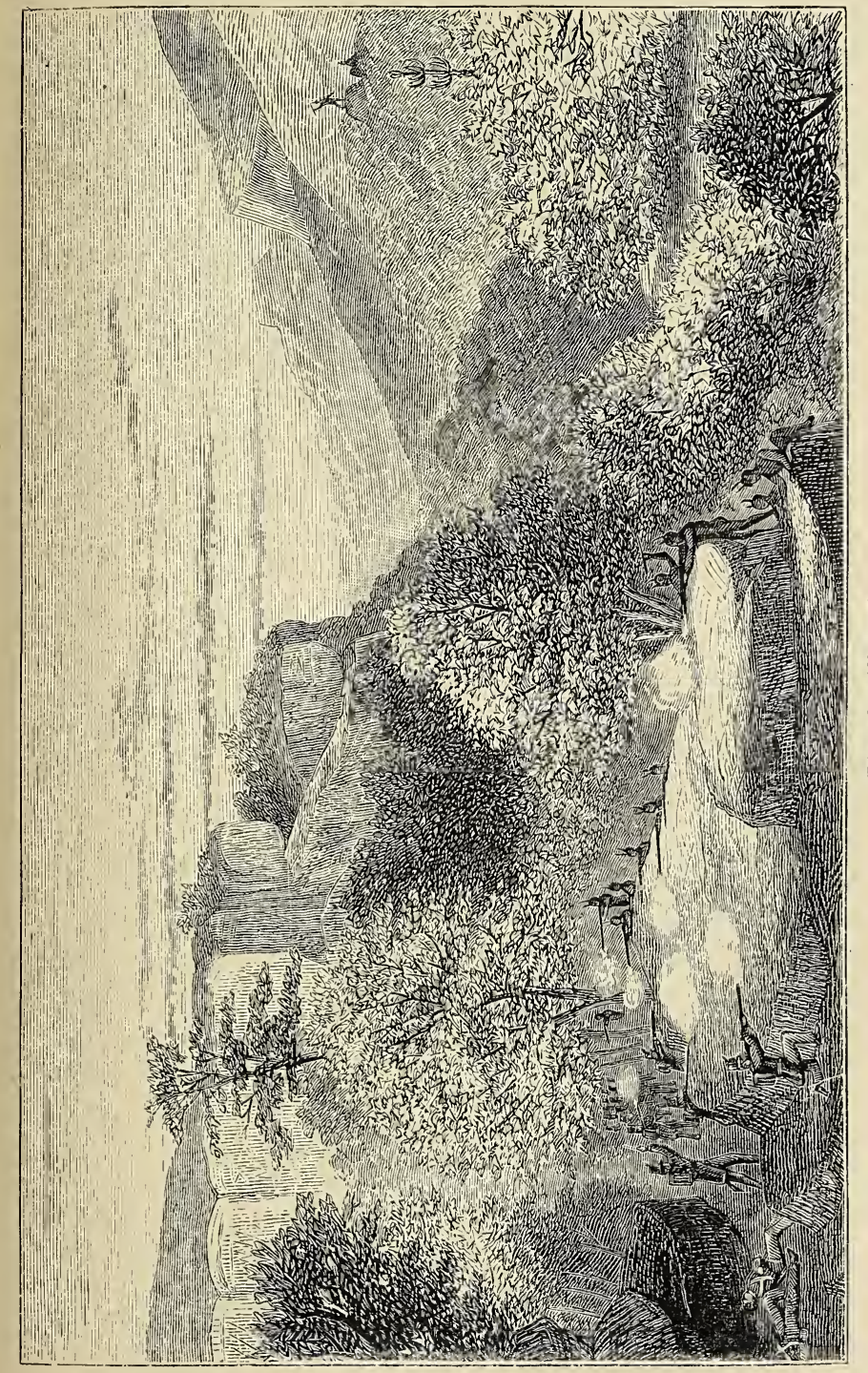



two miles from the river the troops entered the narrow defile. It may, perhaps, be well that I should endeavour to describe the ground. A little on the left was a high precipice, something in the shape of a crescent, its two horns falling away to a ledge. The far end one abutted on the Keiskama River, which ran on the right hand side of the track and conformed to the shape of the precipice, leaving a narrow belt of forestwood between the rocky mountain and the river. The road or track wound through this forest of large trees, rocks fallen from the perpendicular cliffs, and tangled underwood. There were boulders as big as castles, and you had to serpentine and make your way through these as best you could. On the opposite side of the river there was a peninsula-shaped spit or tongue of land sloping down to its banks, with conical-shaped hills at the far end of the tongue; this slope was covered with bush and large olive-trees, as was also the rocky mountain on the left, and in fact the whole of the country around the pass itself.

The troops entered the pass in the order before indicated, and the Kafir police and Cape Mounted Rifles passed through unmolested. Colonel Mackinnon and myself were at the head of the cavalry; and I pointed out the difficulty of the pass if it had been held by the Kafirs, as we should have had to dislodge them from each successive rock. Up to this time no Kafirs had 
been seen in the immediate neighbourhood, although the tops of all the hills and mountains were crowded when we commenced to enter the defile. Each trooper. had to dismount and lead his horse in the narrow parts of the pass, thus dangerously lengthening out the column for some miles.

After passing over the far horn or ledge of the precipice the footpath crossed a ravine and then passed up a bushy slope to the left and on to a small open plateau. The Kafir police had halted upon this open, and a portion of the Cape Mounted Rifles had also reached it, but the rear of the mounted men had scarcely left the pass itself, when all at once first one shot and then a continuous discharge of musketry rang from the centre of the pass.

Colonel Mackinnon was at first loath to believe that the Kafirs had attacked the infantry, but was soon convinced of the fact; and I at once volunteered to go back and take command of the infantry column. I was impelled to do this from knowing by experience more of Kafir warfare than any person presert; and Colonel Mackinnon instantly sanctioned and directed me to do so.

I called to my mounted orderly and made my way back through the bush by the narrow path, with difficulty getting past the mounted men I met on the road. As soon, however, as I had got through the ravine 
there were no more cavalry, and I passed on with my single orderly to the ledge down which I had to scramble before entering the pass. As I reached the ledge my orderly exclaimed to me from behind, 'Myn Got, mynheer, moet niet en gaan!' ('Do not go in'). And I must admit that at this moment I felt my life was in the greatest jeopardy, for I saw thousands of Kafirs running down the tongue of land on the opposite side of the river to head the troops. But I felt that my honour was at stake; that having been sent it was my duty to enter, even though feeling that I must be shot.

I remember pressing my forage-cap down on to my head, setting my teeth together, bringing my doublebarrelled gun to the advance, and pushing my horse down the defile. At this moment three or four of the ammunition pack-horses dashed past me at full speed, bleeding from wounds, and with the pack-saddles turned. and under their bellies. They nearly knocked us over; but we pushed on; and as I approached the head of the infantry column we had to run a regular gauntlet of shot from the Kafirs in ambush and behind rocks waiting for the 'red' soldiers. Before I quite got to the infantry I saw the heads of five Kafirs behind a rock with their guns pointing at me. I gave the horse the spur and dashed on, and at that moment received a gunshot wound low down on the outside of the left thigh, the ball passing upwards and out below the right hip. 
I felt the shock as if struck by a sledge-hammer, and my horse even staggered with the blow, but it gave me time to fire at the Kafirs, who were now exposing themselves. Unfortunately, my first shot struck the top of the rock, whence I saw the splinters fly in all directions; but the second one told in the breast of a petty chief. Strange impulsive utterances cannot be restrained under great excitement. As I was shot the Kafir exclaimed, in his native language, ' I have hit him !' and I could not resist replying, 'I have got it.' But to proceed. After I had fired my horse plunged forward, and I very soon met the infantry, who were pushing their way through the rugged path as best they could. The first thing that pulled me up was seeing a friend of mine, Dr, Stewart, Cape Mountain Rifles, leaning against a rock, the blood pouring from his chest, from the loss of which he was very faint. The Kafirs were keeping up a perpetual fire on the troops, which was returned in the most gallant style; but not a sable enemy could be seen in. the dense wood from which they fired. At this moment a second ball struck Dr. Stewart in the head, and his brains were spattered all over my face and jacket.

To make a standing fight in the position in which the troops then were was impossible, the footpath wound round the great rocks and forest-trees in such a manner that you could not tell whether it was friend or foe that 
was firing; and there was, therefore, no alternative but to press forward and get the men out of the bush. It must also be remembered that the column, being in Indian file, extended for a great length along the pass.

The head of the column soon fought its way over the advanced horn of the cliff, and made a stand, driving back a large mass of the enemy, who had come round the base of a wooded hill where the ravine entered the Keiskama River. This portion of the column then forced their way up the wooded slope and gained the open, where the Kafir police and Cape Mounted Rifles were formed up; but the centre of the broken line of infantry was attacked with such impetuosity that they had to diverge from the regular track after passing over what I call ' the horn,' and were forced through the bush on to the open some distance to our left rear.

I managed to sit my horse until I reached the cavalry; but as I approached a knot of dismounted brother officers I felt so faint that I should have fallen from my horse had I not been caught by one or two of them. The blood had been continually pouring from my wounds, and I should have bled to death before a doctor arrived had it not been for Carey, who had a tourniquet round his body, which he at once took off and applied to my thigh, and so partially stopped the bleeding. 
Dr. Fraser, one of the finest officers in the service, who was the second medical officer, soon arrived on the spot; but the excitement and anguish of mind had been too much for him, and as he kneeled down to examine my wounds he fainted-grand, fine fellow! It was not from the sight of my wounds that he did this, but from the knowledge that he had to leave the dead and dying in the pass to the merciless tortures and mutilations of the savage enemy. I always carried a flask of cold tea with me in the field, which I managed to take off, and offered it to Fraser. The cool beverage soon recovered him, and his first exclamation was, ' Oh, my God! I was obliged to leave Stewart.' Now, I must here record to the honour of Dr. Fraser that he is one of the most conscientious and bravest men in the service, and in the hurry-scurry of the attack in the bush he would not leave his horse with the medical panniers; and he was lugging this brute along in the rear when a ball killed the horse and he fell. Fraser had then to hurry on, and it was while passing the dead and dying that were being mutilated by the enemy that the Doctor heard a voice exclaim, 'For Grod's sake, Fraser, don't leave me.' Had he hesitated for one moment his throat also would have been cut, and he was obliged to pass on in order to overtake the rear of the column. In his imagination he thought it was Dr. Stewart who had appealed to him, and this made the agony of the 
moment still more painful. On this point, however, I was enabled to relieve his mind, for in pointing to $\mathrm{my}$ jacket I asked him what the spots were; and on his seeing that it was human brains, I told him that they came from Stewart's head; nevertheless, he could not overcome the agonising thought of having been obliged to leave the wounded men.

This has taken me some time to tell, but all this time Dr. Fraser was dressing my wounds; that is to say, he was plugging up the holes and adjusting the tourniquet. Before he had finished, however, a man ran up to say that Captain Catty was badly wounded and dying; so I told the Doctor to go at once; but he soon returned, saying he could not help Catty, and from indications he thought nothing could save him-three balls appeared to have entered his right side and passed into the intestines.

While the troops were halted on the open a very large body of Kafirs were massed on the top and sides of a conical hill immediately on our right; and I pointed out to Colonel Mackinnon, who was standing close to me, that unless he sent out some men they would outflank us. The Colonel replied that he had already done so, and had extended the Kafir police on our right flank.

This circumstance saved us from a heavy fire from the enemy, as from their commanding height they 
could easily have fired upon us; but the Kafir police being on the right, had they done so the balls must have whizzed over their heads to reach us. This would have been a breach of faith to them, for it was afterwards known that arrangements had been made that the Kafir police should go over in a body to the enemy on the first engagement. Overtures had also been made to the Cape Mounted Rifles to join the Kafirs. Hence it was that the Kafir police and Cape Mounted Rifles were permitted to pass through the Boomah defile without being attacked; and that is also the reason why the enemy did not dare to fire over the heads of the police, as it would look as if they were firing at them. The Kafir police did not go over at this moment, because Sir Harry Smith had prevented their wives from leaving the police barracks at Fort Cox, as they had endeavoured to do, and this was duly reported to the men.

Twenty-three soldiers were killed in the pass or fell into the enemy's hands, and were tortured to death. Several soldiers were seen to be seized by the Kafirs as they discharged their muskets, and were pulled into the thick bush and killed. None of these poor fellows' bodies were ever recovered. Twenty-three others were wounded, but luckily for them were able to keep up with the fighting men.

We had now to push on for two or three miles 
through a comparatively open country to the Keiskama Hoek, where we formed a camp for the night-I say camp; but as there was nothing but soldiers without tents, it was a queer sort of camp. What we did was to form a square, with the soldiers lying down with their muskets facing outwards. The Doctor then attended to the wounded. My mode of conveyance from where I was lifted from my horse to the camp was far from a pleasant one. It was in this wise : a man got me by each arm, with his elbow well into my armpits; my face was towards the ground, every now and then scratching over mimosa bush, brambles, and long grass; whilst a third man was between my legs, well up into the fork, with one of my thighs tucked under each of his arms. I don't wish my worst enemy to be in the same position.

Dr. Fraser was most kind and attentive to the wounded; and I was plugged and bandaged up in a most comfortable manner. Captain Catty's were the most extraordinary wounds. All the fire from the enemy came from the right side of the defile; hence I was shot in the left thigh advancing to the infantry; while Catty had received to all appearance three balls on the right side. Strange to say, not one ball had actually passed into his body; one ball struck the small rib and came uut again within an inch or so of where it entered; the second ball also struck a rib, and from there ran up under the skin and lodged, where it was 
cut out, high up on the chest; and Catty, who the Doctor at first thought could not live, was well in a few weeks, while I was for two years on crutches.

There was a missionary station at the Keiskama Hoek, under the Rev. Mr. Nevin, and it was at first proposed to leave the wounded men at the station, as it was known that the troops would have to fight their way back to Fort Cox the next day. Fortunately for us that arrangement was not carried out, for the station itself was attacked a few days afterwards, and the church and mission buildings burnt to the ground. The missionaries and their wives were, indeed, allowed to march out; but whilst making across the Amatolas for the Chumie mission station, carrying Mrs. Nevin, who was an invalid, a separate party of Kafirs fell upon them en route, ill-treated them, and stripped them all naked before letting them pass on. In fact, Mr. Nevin's life was only saved by the heroism of a high-caste native woman-afterwards our servant-who threw herself between the assaigai and her teacher, and from being the sister of Sandilli's chief counsellor her entreaties were listened to. This woman was also the sister of Togo Sogo, the Kafir who was educated at Glasgow, became a missonary, and married a white lady, the daughter of an elder of the Scotch Church.

The day I was wounded was my birthday; the one following was Christmas-day 1850, and it was rather a 
memorable one. After a consultation it was decided that the troops could not march back to Fort Cox by the route they had come; and Colonel Mackinnon was still most anxious to avoid a general war. The only other route was a considerable circuit, but it was a comparatively open one. Christmas-day at the Cape is usually the hottest of the whole year. The troops fell in at daylight, and the route was declared to be over the low range of the Guilli-Guilli Mountain, through the valley of the same name, over the 'neck' at Bailie's Grave, and through the Debe neck to Fort White.

As the troops broke into column we saw large masses of Kaffirs collecting on all the mountains; not yet knowing which way our route would lie. Orders were given on no account to fire on the Kafirs unless attacked. After crossing the Keiskama river and passing up a rather bushy valley the troops had to climb the face of a very steep mountain with bush approaching on each side as you reached the top. The heat this day was something wonderful; and as the men reached the top of the glade and mountain they threw themselves down perfectly exhausted. The men had taken the field with their knapsacks; these the young soldiers tore from their shoulders and threw away. While they were still somewhat in confusion a volley was opened by the Kafirs all along the bush, where they must have been lying in ambush. The cavalry were still climbing up the 
steep hill, but the infantry fell in and opened fire on the enemy. Our position, however, was so unfavourable that an advance was ordered. At the top of the mountain the glade continued four or five hundred yards, with bush on each side very close up, and large shelving rocks on the left, known afterwards as the Marine Rocks. The troops had to push their way through this glade under a heavy fire from the bush and rocks the whole time. It is, therefore, not to be wondered at that there was a little haste and confusion. The four men who were carrying me in a blanket dropped me in the grass and ran on with the stream. I knew perfectly well that the moment the rear passed a Kafir would run out of the bush and cut my throat. I therefore tried to pull myself along on my back in the grass with my hands, but I made very little progress. The cavalry were now passing at the trot. Several horses were shot in the mêlée ; and a serjeant named Extein was running on foot, when all at once he fell over me in the grass. Looking round, he rose and said, ' Ohg, myn Got, is dat zuer ?' I replied, 'Yes, Extein ; don't leave me.' And he answered, 'No, sir.' Catching hold of the reins of four successive troopers as they were passing, he ordered the men to "dismount, let the horses run loose, and said, 'Carry on the master.' In this way I had my life saved on the second day.

The troops soon got through this narrow defile, and 
then attacked the Kafirs in turn ; but the natives very soon knew when they had lost the advantage, and consequently disappeared. The column, however, became encumbered with more wounded; and the men were so utterly exhausted from the great heat and thirst, and from biting off the ends of the cartridges.(for we still in those days carried the old ' Brown Bess'), that Colonel Mackinnon marched on to the Quilli-Quilli River, in the open valley. Here he intended to halt and give the troops their breakfast; but the Kafirs collected in such masses of cavalry and infantry that the troops could not light fires, and could only halt under arms. After this halt the troops had to march up a long winding valley and over a neck of land between wooded ravines towards Bailie's Grave. The rear was very much pressed by large bodies of the enemy, and the Cape Mounted Rifles had to charge several times to keep them in check. Napier, Carey, Boyes, Whitmore (who commanded the rear guard), Stuart-Wortley, and others distinguished themselves greatly on this occasion.

As we approached the bushy neck alluded to the Kafirs gaining confidence, were pressing the rear very hard, and the wounded who were being carried all fell more to the rear than they should have done. I noticed that some of the young soldiers were getting unsteady, and I remember raising myself in the blanket, putting up my arm, covered with blood, and 
saying to the men, 'By G-, soldiers, if you do not fall in and be steady, the Kafirs will rush in and stab you like sheep.' It must be borne in mind that these men were chiefly young soldiers; they had but recently arrived in the Colony, and most of them had never been under fire before. They only required guidance, for they immediately fell into order, showed a steady front, and the Kafirs were checked at once. Mackinnor, who was coming to the rear, must have seen what happened, for he rode up to me and said, 'Well done, Bisset!'

General Mackinnon is one of the coolest men under fire that I have ever known. I have seen him advance on horseback with an attacking party against the enemy, posted in strong positions, smoking his cigar in the coolest manner while the bullets were falling about like hail.

We then moved on down a long slope, and crossed the stream at the real Bailie's Grave-I say the real, because I buried the remains of this brave man at this spot in the Kafir War of 1835. He fell there with twenty-eight men, fighting bravely, and not one escaped to tell the tale. It was not until some time afterwards that we found the remains and buried them in two graves.

This Charles Bailie was a fine fellow. He was a lieutenant, and a brother officer of mine, in the 1st Battalion of Native Infantry, during the Kafir War of 
1834-5; his father was one of the British settlers of 1820 , and a friend of my father's. When just grown up, and residing on the Hope Farm, in Lower Albany, he was called upon to act as a special constable and assist the law officers to seize a desperate character named Fletcher who had committed a serious crime and resisted the law. On entering his house the man raised a gun, and was in the act of shooting a constable, when Bailie put up his pistol and shot the man in the arm, intending only to disable him; but the ball glanced after breaking the arm and killed the man on the spot. Bailie insisted upon being tried by the Circuit Court Judge, who not only honourably acquitted him, but passed the highest encomiums on his conduct.

However, it made such an impression on Bailie that he became a very religious man; he preached on all convenient occasions to general congregations as well as to his men, and always carried a Bible in a spare pouch on his person. On the occasion of his death, in the war of 1835, he had been pursuing a large body of Kafirs who had passed out of the Umdezene Bush; he followed them into the Amatola Mountains as far as the Keiskama Hoek. The enemy, seeing the smallness of the party, decoyed him thus far and then fell upon him, and he had to retire fighting by the very route we had come. He had lost one or two of his men; 
but when he arrived at the stream where he was killed he was met and surrounded by a fresh party of Kafirs and overpowered in the long grass, not a single man escaping. His men fought most braveīy so long as their ammunition lasted, and a large number of Kafirs were killed.

For months no tidings could be obtained as to what had befallen the party, but at last it becoming known that the chief, Maccomo, had got possession of Lieutenant Bailie's Bible, he was bribed for a consideration to part with it; and on the flyleaf was found written a statement that he was then surrounded and his ammunition failing.

We searched and found the remains in a decomposed state, Bailie's being recognisable only from the long hair and black whiskers that had fallen on each side of the skeleton. His father was a captain in the same battalion, and was with me at the time we buried the remains of these poor fellows. The graves are now marked by green bushes growing over them-a fitting memorial to a soldier's grave. 'Where the tree falls there let it lie,' is my idea of what should be. This is rather a long digression, but I record it in honour of the dead and to the memory of a friend.

From the stream at Bailie's Grave the road or path led by the base of a mountain called Taban Doda, or the Men's Mountain. It was literally so on this day; 
for the mountain was covered with a black mass of warriors, who pressed the troops so much that the column had to diverge to the left, more into the open, and proceed over the Kometjes Flats before reaching the Debe Neck. The four men who were carrying me over this rough ground halted to rest, and for the sake of shelter from the bullets I was deposited in one of these kometjes, or basins in the ground; and one of the men took off his wooden canteen to drink from. No doubt I was in a high state of fever, and verging on delirium, for I can only just remember that as he was leaning over me and drinking he let the canteen fall, and it struck me on the nose, breaking the bridge. I felt the stunning blow, but that is all; and I heard his comrades abuse him for his carelessness, and the poor fellow reply that he could not help it.

After continuing about three miles over this rough country, we came to the Debe Neck, where there was a good deal of fighting to beat off the Kafirs. At the Neck itself a most horrible spectacle met our eyes. The day before-that is, the day we were attacked in the pass-two soldiers who were escorting a provisionwagon from King William's Town to Fort White were attacked and killed; and a report having reached Fort White to this effect, the officer commanding sent out a party to bring in the bodies. This party was also attacked at the Neck and every man killed, and we had 
to pass over the bodies of nineteen men, which were most brutally mutilated: their heads severed from their bodies and carried away to exhibit to the different tribes, as an indication that the white man was destroyed, and for the witch-doctors to work their spells upon. This was done by the doctors, or devils, passing a stick, with a cross-stick at the end, in the shape of a whisp, into the lrain-hole at the back of the skull, and then turning it sharply between the palms of the hands until the brain was mashed up and frothed over. Then the 'devil' would withdraw her diabolical charm-stick and sprinkle the brains in all directions, making her incantations all the time, to turn the soldiers' bullets into water, and to make her own people invisible to the foe.

After beating the Kafirs off at the Debe Neck there was no more fighting that day, and we reached Fort White, where the troops halted for the remainder of the day. Knowing, however, that Sir Harry Smith, the Commander-in-Chief, was in the meantime shut up in Fort Cox, Colonel Mackinnon was most anxious to rejoin him. After, therefore, making arrangements to strengthen Fort White, he made a night-march, and so took the Kafirs unawares, and reached Fort Cox without much more fighting. The badly wounded and Dr. Fraser were left at Fort White, and Captain Mansergh, of the 6th Regiment, left in command, with 120 men, 
Captain Vialls and the 45th detachment, previously holding the post, proceeding on with the column to rejoin their head-quarters, at Fort Cox. On the same day that we arrived at Fort White the post had been attacked by a large body of Kafirs; and although they were beaten off, they managed to capture the whole of the slaughter cattle, so that the post was left with a very small supply of provisions.

It was well that so energetic an officer as Captain Mansergh was left at Fort White. He was one of the best war officers I have ever known, and his soldierlike qualities soon afterwards saved the post from being taken by the enemy.

The wounded were accommodated in wattle-anddaub huts, but every available man was set to work to build or erect an earthen parapet, breast-high, between each hut, and to construct a couple of flanking bastions at corresponding angles of the square. This precaution was not taken too soon. On the second day the post was attacked by an innumerable horde of savages, led forward in three great columns, Sandilli and his chief councillors directing the whole movement, but themselves remaining out of gunshot. $\mathrm{He}$ was riding Colonel Mackinnon's cream-coloured charger, captured a few days before.

It was nothing but Mansergh's cool bravery that saved the post from being taken. There was not one 
man to each opening between the huts; but, a small ' handful' of men was placed in each of the two bastions, with orders not to fire on the advancing columns until they got the word from Mansergh himself, who was stationed in the lower bastion.

The detachment of Cape Mounted Rifles under the command of Lieutenant Smyth was drawn up to defend the lower intermediate angle of the post, at the corner just outside their own huts. It was a critical moment, for the columns of Kafirs were approaching, led on by their chiefs; when all at once the sergeant and two men ran out from the ranks, holding up their arms, and made directly for the head of the nearest column of Kafirs, and joined the enemy. I am sorry to say the officer lost his opportunity of shooting them on the spot; but at this critical moment it became necessary to disarm the remainder of the detachment, about twelve in number, who were made prisoners and huddled into my hut. Those that I knew personally and could rely on had their arms restored, and joined the Line soldiers in the bastions; but the other cowardly rascals fell to praying aloud, saying that ' the last day had come.'

As an addition to our difficulties, on the same night that Colonel Mackinnon's column reached Fort Cox the whole of the Kafir police, several hundreds in number, went over to their countrymen, with their arms and ammunition : and one of the columns attacking Fort 
White was partly formed of these men. The three deserters from the Cape Mounted Rifles were at once taken up to Sandilli and placed upon his staff.

During the two days' respite the suttlers of the post had all taken refuge within the fort, and their houses had been pulled down, with the exception of the brick gables, so that there was very little cover. The Kafirs could not resist firing as they advanced; but Mansergh allowed the columns to approach to within thirty yards, when we heard his stentorian voice give the order, 'Men, steady; except the reserves, fire!' And then such a volley was poured into the heads of the savage columns that they fell into utter confusion. Three chiefs and twenty-two men were shot down. During the confusion caused by trying to carry off the chiefs the reserves put in their volley, and there was then such a continuous fire kept up from the handful of men that the Kafirs turned and fled. It was then that the British cheer rang from each throat. The Kafirs took cover in all the gullies, cranks, and crannies behind the gables of the houses and the banks of the river, and kept up a desultory fire on the post for about three hours; but they came no more to the attack, and finally drew off to the high grounds in the neighbourhood. By this time the whole of Kafirland was in arms against us, and Sir Harry Smith was shut up at Fort Cox for more than ten days, without any communica- 
tion whatever with the Colony or any of the military posts. We were threatened every night and attacked nearly every day, but not again in a formidable manner. We were first placed upon half and then upon quarter rations; but even on this scale the provisions at the post could not last long. There were no medical comforts, and I was kept alive in the most extraordinary manner.

Amongst those that fled into the post there was a dear, kind lady named Mrs. James. Like all ladies when in a fright, they snatch up the first thing that comes in their way; it may be a bonnet, a ball-dress, or a turkey. Luckily for me it was in this case the last; and that turkey, under God's good Providence, kept me alive. It was not like the goose with the golden egg, for it was a turkey producing the daily nourishment of life. Nothing but this sustaining egg could have pulled me through. The suppuration from my wound was so great that without sustaining food I must have died. My pulse was 130; I was in a high state of fever, and delirious for days ; and next to the turkey I am indebted to my kind friend Dr. Fraser for my life. His attentions were unremitting-by day or night he never left my side. On the fourteenth day secondary hæmorrbage took place at night. I was lying, under the influence of morphia, in a sort of trance; Fraser was lying in the hut near me; my eyes were fixed, yet I had my senses. 
Fraser heard what he thought a sort of rattle in my throat, and started up. I appeared more to feel than see all this. He rushed to my bed, felt my pulse, and looked scared, ran to his little kit, and brought back a small round looking-glass and held it to my mouth, dropped it, and rushed for a little vial, from which he poured drops down my throat, and I soon became more conscious.

He then threw open my blanket and found me saturated in blood. He told me afterwards that I was in too weak a state for him to cut down and re-tie the artery, and that he was obliged to keep me suspended between life and death until coagulation had stopped the bleeding. The course of the bullet had cut the sciatic nerve in two; during this period my leg became doubled up; and as I could not be moved it became fixed in that contracted position; ultimately I had to be sent home by a medical board to have an operation performed.

We were shut up at Fort White for about six weeks. Occasionally we received the smallest of small despatches from Sir Harry Smith, urging us to hold out until he could raise the siege and relieve us. These despatches were brought by naked renegade Kafir messengers. They were rolled up about the size of a quill, for these messengers were repeateàly waylaid, caught, and searched; but they were always clever 
enough to evade questions as to their destination and to preserve their despatches. The Equibeka mission station was not very far from Fort White. The missionary was at that time under a sort of cloud, and he had gone to the head missionary station, at the Chumie Hoek, where there was a conclave of missionaries sitting in judgment upon their brother. Men from England had been sent out as members of this missionary court-martial, and while this was going on, the Equibeka station itself was burnt and plundered, by the very people they were trying to civilise.

The ladies of the establishment were so far protected that they were allowed to leave the station with the clothes they had on their backs. They were making their way on foot to join their friends at the Chumie, when unfortunately they were met en route by other Kafirs, who maltreated them and took every stitch of clothing from their persons. This happened near Fort White; and we were shocked one morning, just after daylight, to see two white ladies approaching the post without a rag to cover them. There was no help but to confine the soldiers to their huts until my good friend Mrs. James had gone out to meet the poor creatures with some clothes.

We felt deeply for these ladies. One of them was a most charming person, the beautiful and highly edu- 
cated daughter of one of the oldest and most respected missionaries of Kafirland, and had not long been married.

From day to day the post was surrounded by the enemy, and we were told each night that the attack would be renewed next day; but they must have had enough of coming to close quarters, for they never repeated the experiment.

We could, however, hear desperate fighting going on at and in the neighbourhood of Fort Hare. Sir Henry Somerset, whose head-quarters was there, endeavoured to communicate from that post with Sir Harry Smith, the Governor and Commander-in-Chief at Fort Cox, where his Excellency was still shut up. A strong column marched under Major Yarborough, of the 91st Regiment, who had also a field-gun with him; but the party was attacked in such force by the Kafirs, after getting nearly half-way, that they had to retire fighting the whole distance back to Fort Hare. The gun got entangled in one of the fords, and had to be abandoned, and two officers and twenty-two men were killed fighting hand-to-hand with the enemy.

A large number were also wounded, and the retreat was performed with much difficulty. Charles Somerset, of the Cape Mounted Rifles, distinguished himself in this affair, as he also did afterwards at the storming of Fort Armstrong, an abandoned military post taken 
possession of by the rebel Hottentots of the Kat river settlement and by the Kafirs.

During this time the military villages in the Chumie Hoek were also attacked, and nearly all the men killed, with many of the women and children.

About ten days after the affair of the Boomah Pass, Sir Harry Smith, with a strong party of Cape Mounted Rifles, cut his way through from Fort Cox to Fort White, where, after a short halt, he proceeded on to King William's Town, the established head-quarters of British Kaffraria. On arrival at Fort White my friend and old companion-in-arms Johnny Armstrong was desirous of carrying me on in a litter to King William's Town, and proposed to construct such a thing as could be carried by four horsemen; but on mentioning it to Sir Harry Smith he very wisely forbade it, and it is fortunate for me that he did so. The whole force was hotly attacked at the Debe Neck, and had to diverge from the road and pass over this wonderful Kometje Flat at a great pace, so that any litter must have been dropped, or I must have been jolted out of it, for no two horsemen could by any chance have been on the same level at the same time.

The troops had to contrive all sorts of means to exist. The regular ration consisted of a quarter of a pound of salt meat, with four ozs. of biscuit. Luckily there was a fair supply of barley and oats, and what 
with barley-water and some vegetables they managed to hold out until we were relieved by a column of troops arriving with supply-wagons from King William's Town six or seven weeks after the commencement of the war. This could only be done after the arrival of troops and levies from Cape Town, which landed at East London, in Kaffraria. However, we were all greatly rejoiced. The post was supplied with food and also strengthened, and I was carried back in one of the empty wagons to King William's Town. 


\section{CHAP'TER XVIII.}

THE HONEY-BIRD.

There is a small bird in South Africa whose instinct and peculiarity appear to be but little known in natural history; it is called the Honey-bird, and is about the size of an English water-wagtail.

When hunters approach any forest, wood, or ravine this bird invariably makes its appearance, and commences chirping, or ' talking,' as the natives call it. The chirp is a cher-r-r, cher-r, repeated over and over again. The hunters answer by whistling and making a noise from the throat-a sort of hoig, hoig. The bird flutters, becomes excited, and flies on from tree to tree, sometimes fifty or a hundred yards at a time. If you are slow to follow the bird will come back, meet you, and go on again; in this way it will take you any distance-it may be a hundred yards, a mile, or even more, but it leads you direct to the bees' nest, or wild beehive, which is generally found in the trunk of hollow trees. 
As the bird approaches the 'bees' nest' the chirp turns more and more into a cluck, like a hen giving a grub to her chicken. The bird at last will go as near as it can to the hive or hole in the tree, and then cluck and point with its little bill towards the small hole through which the bees pass in and out. After doing this the bird remains perfectly silent, to indicate that it has shown you the hive. When the bird sees that you have discovered the bees' nest it starts off again, chirping and clucking, and in that way shows you from one to six or seven nests of honey.

On one occasion, when I was en route with the troops overland to take possession of Natal, in 1843, one bird during our morning halt showed me seven bees' nests one after the other. We took out more honey from them than the whole squadron of cavalry could consume; and quantities were carried on in the comb to the infantry, who had marched in advance.

The natives, both Kafirs and Hottentots, have an idea that there are 'wicked' birds as well as 'good' ones, and say that some birds will take you to a tiger, a buffalo, or a snake, \&c. The bird always ceases to chatter after it has shown you a nest, and instinct takes it in a direct line to where the nest is. It thus very often happens that you stumble on one or other of the above-named animals or reptiles. The flurry frightens the bird, and it ceases to ' talk ;' hence the supposition 
in the native mind that it has been ' wicked' and lured the hunter to danger.

Sometimes the bees make their hives in cavities under the surface of the ground or in hollow anthills, which are generally in the open, and not in the bush; and as there is then no tree on which the bird can settle it will fly from the nearest tree or bush and make a swoop, flapping with its wings, down to the ground, to show where the bees' nest is. Very often these hives are difficult to find, even after the bird has shown the spot, as the orifice in the tree or ground is not larger than a gimlet-hole, or if larger the remaining space is filled up by a dark-coloured wax called ' beeswork.' Moreover, in cold or rainy weather the bees may not be working - that is, gathering honey - and you have then to apply your ear to any crevice or hole and listen for the 'drone' which always proceeds from the swarm. On your striking the tree with anything hard the drone becomes a perfect buzz; and it is well if you do not get a sting or even a dozen of them before you move away.

The mode of taking a nest is to chop a hole in the tree large enough to admit a man's hand and arm, and puff tobacco or other smoke into it; the bees then soon become stupefied, and swarm or cluster away, after which you take out the honeycomb.

All this time the honey-bird is watching you so 
closely that it is not a yard off; and if you place a small piece of the honeycomb on the branch of a tree the bird will at once commence making her repast. It will, however, rarely take you to a second bees' nest after it is once satisfied.

In connection with the foregoing, I must here recount the following particulars regarding the death'shead moth.

The death's-head moth, as found in South Africa, is about the size and length of a man's finger, and it has a most perfect death's-head-and-marrowbones painted by Nature with all her beauty on its back. The legend, both amongst the Dutch and the natives of the Cape of Good Hope, is, that this moth has a sting, and that a puncture from it causes instant death. This moth is generally found in beehives, particularly when they are in the ground or in decayed trees.

One of the seven nests which the honey-bird showed me when en route to Natal had two of these death'shead moths in it; and a most ludicrous scene took place. while we were taking out the honey. There were some Cape Corps Hottentot soldiers standing about looking on. Charles Somerset, who cared so little for the sting of bees that he got the name of the ' Rattle,' or badger, was taking out the horeycomb from the hollow of a large barboon or bean-tree, which grew out parallel with the earth and a few feet above it. 
All at once we heard a rumbling sound like distant thunder, with a 'burr' in it, and the Hottentot soldiers exclaimed, 'Och, myn Got!' starting off as if Old Nick had kicked them. Somerset tumbled from the tree, and we seven brave British officers took to our heels as fast as our legs could carry us, following the Totties, each thinking that a lion or a tiger was going to catch the hindmost. We ran fully one hundred yards before we overtook the nimble Totties, which we did at last, and demanded what the cause of alarm was. 'Uch, myn Got, zeur, dat is de Dood moot!' ('It is the death moth!') they exclaimed, and we all burst out laughing to think that a British army had been put to flight by a moth. The Hottentots still appeared terrified, and each of them broke off the branch of a tree and looked about them, when a big moth certainly appeared and kept circling over our heads. One of the natives struck it down with the branch. It was a good deal bruised; but the 'Doctor,' one of our party, examined it, and declared there was a sting in the great insect's tail, and that it was not known in natural history that any moth had a sting.

We then started to return to the bees' nest but nothing would induce the Totties to accompany us, as they declared that they had seen two moths come out of the hive. We, however, were not to be daunted, and, marching back in a body, proceeded to take out the rest of the honey. 
The Hottentots, finding that we were not all killed, gradually came back and looked on. I was standing a little way off-for I must confess that I am more frightened of the sting of a bee than of a man or woman either-with my hand on the branch of the tree, when all at once one of the natives standing behind seized me round the neck, and pulling me head over heels backwards, held me on the ground, pointing to the other moth, which was perfectly quiet, and not an inch from my hand.

Dr. Courtnay took out his penknife, pinned the moth to the tree, and subsequently examined it also, declaring there was a sting. The Doctor preserved this specimen of the 'Dood moot,' with the intention of sending it to the Medical Institution.

Many respectable Dutchmen (one a Field-Cornet De Lange) have declared to me that they have known death to ensue from the sting of this moth; but there has, in my mind, been something to account for death in a more reasonable manner. For instance, when the Boer has been taking out a bees' nest on the face of a precipice, or from under an overhanging rock, and the moth has come out and stung the man, he has dropped from sheer fright to the bottom of the 'krantz;' so that, whether he was stung or not, the fall would in all probability be the cause of death. All assert that there is a small inflamed blue or black mark where 
the moth stings you, and that death is almost instantaneous.

I have certainly often found them in bees' nests, as the wild hives are called, and have heard them make this rumbling sort of noise; but we always watched and killed them with a bough or branch as they came from the nest. Such hives are generally without honey, or at least contain very little.

There is also a small animal in South Africa, known there as the 'Rattle,' a description of badger, which displays great intelligence in searching after wild honey, on which it lives and for which it will follow the honey-bird to find the hive.

The bird must be aware that the rattle scratches and gnaws away the entrance-hole to the bees' nest to get at the honey, and that in taking out the honeycomb there is a certain portion which falls to the bird's lot. At any rate, each appears to know the peculiarity of the other, for the bird, on seeing the rattle, will fly on from tree to tree cher-r-r-ing and clucking until she comes to the beehive; and the rattle will follow, making a grunting noise from time to time.

The rattle is a very thick-skinned animal, and cares little for the sting of the bees; yet nature has provided it with the power of ejecting a peculiarly strong smell, which appears to stupefy the bees, and they 
swarm away from the honeycomb. The Rattle will then take out the honeycombs one at a time, and carry them sixty or eighty yards from the hive, to prevent the bees from settling upon them, placing the combs one upon the other.

The native 'herds' often come upon this animal while taking out a bees' nest and rob the store of honey which has been carried away from the hive; but woe betide the man unless he is well armed, for the Rattle will at once on his return to the place detect the the robbery, make a ' cast' round the spot, take up the spoor or track, and follow and attack the robber, who with his ordinary stick has but a poor chance.

The Rattle is not a large animal, but it is very tough and tenacious of life, nor can you kill it by beating it with sticks. The ' herds' are generally naked savages, without boots or shoes to protect their feet and legs, and the Rattle invariably attacks the heel at the tendon Achilles; but as this animal is very short-. legged the Bushman or Kafir takes refuge on the top of an anthill and belabours the little beast from above. He may nevertheless be kept for some hours in this position, not daring to leave the elevated mound. The skin of this animal is so tough and thick that an ordinary assaigai will not penetrate it. 


\section{CHAPTER XIX.}

LOCUSTS AND WILD HONEY.

I wiLl here, as an addendum to this article, note down my idea on the above subject. Many theories are set up regarding the possibility of the above-named insect forming an article of food, and some divines, particularly those who have been in the East, consider that the bean from the locust-tree is the substance referred to in Holy Writ as forming the diet of John the Baptist in the wilderness, but I verily believe that it was the real locust, with wild honey, upon which he subsisted.

In South Africa the locusts, under the name of grasshoppers, are truly a plague, as they were in Egypt. Periodically they come down from the interior in such vast flights that the very sun is darkened for days and days as the continued clouds of these insects pass on between heaven and earth.

These great flights of locusts settle at night, and I have often seen them a foot or more deep upon the earth; they cluster more particularly upon any tuft of 
grass or inequality on the ground. They generally take wing again the next day ; but on very still days-that is, when there is no wind-they will not take flight but move on, flying only short distances, and devouring everything before them. Where they settle at night not a vestige of herbage is left the next morning. Providentially their course is generally to the.south, which brings them to the great Indian Ocean, on whose bosom they at last alight, and are thrown back again upon the beach dead.

I have seen them washed up on the sands for hundreds of miles, some five or six feet deep, polluting the air to a great distance from decomposition.

The country through which this scourge passes is denuded of all pasture and green herb, and nothing can save the farmer's crops or gardens; nevertheless every description of animal will live and even fatten on the locusts themselves. Horses, cattle, sheep, pigs, dogs, poultry, all devour them with avidity, and become so fond of the insect that, when the locusts are getting scarce, you may see any or all of these animals running after a single locust on the wing to catch it. There is an after-result of this scourge which is worse than the first: wherever the vast millions of locusts alight at night they deposit their eggs, and in a few months you see the very earth become alive with diminutive insects, which develop themselves from 
day to day, first into a moving mass of black minutice, and from that increasing in size and becoming the colour of the brightest red.

At this stage they are called the 'Rooi baatyes,' or red soldiers. It is some time before the wings are developed, when they again change colour to locustbrown, and take to flight; and it is curious that when they do this their course is generally inland, in contradistinction to their progenitors which came from the interior. The unfledged locusts are also called the 'foot-ganghers,' or font-soldiers; and nothing can impede their advance, which they generally make on the prinof the wedge, with the thin end first. Rivers of water will not check their forward movement, for they plunge headlong into the water, until the dead make a bridge for the living.

About the year 1830 some of the dispersed native tribes from the interior of Africa migrated into the Cape Colony to seek employment among the farmers. The tribes were called Mautatees, and Bucuanas, and my father engaged one family, consisting of a man named Job, and his two wives, Mashalee and Anna, with seven or eight children. Soon after their arrival a flight of locusts came from the interior, and night after night whilst the locusts were settled on the earth the whole of this family, with great sandals of ox-hide tied on their feet (very like Canadian snow-shoes), would walk 
about the whole night wherever the locusts were thickest.

The next day the locusts would again take wing; but where this family had been walking about all night you saw acres and acres of ground covered with swarms of disabled locusts that could not fly away; and the natives would collect them and bring them home in baskets; they would then break off the wings, pinch off the tail-end of the body and pull off the head, and with it withdraw the inside of the locust; thus the body and legs only remained, the inside of the body being covered with fat.

This portion of the locust was then spread open upon mats in the sun to dry, and when dry packed away in huts raised from the ground, and built on purpose. These people received a very good ration of food-and the necessaries of life were exceedingly cheap at the Cape in those days-yet this family preferred the bread made from these locusts to any other description of food. Their mode of manipulation was as follows: A basket full of the dried locusts would be taken from the store, and one of the women would sit down on the ground by a flat stone, and with another round stone in her two hands would grind or reduce the locusts to flour, and therewith make thick cakes and bake them on the coals or in the ashes, and eat this locust-bread with wild honey. 
Honey was most abundant in the country at this time ; and I have seen Job after a day's hunting carry home leather bags full, weighing more than I could lift from the ground. Hence I believe that it was thus that John the Baptist 'lived upon locusts and wild honey' in the wilderness.

There is a bird called the locust-bird which follows the great flights of locusts from the interior; these birds remain always on the wing, and devour the insect without ceasing. They appear to be appointed by Nature to diminish or keep down the plague of 'grasshoppers,' for they are never satisfied, but continue whirling amongst the locusts and cutting them to pieces with their bills; nor can you tell what portion these ravenous birds feed upon.

Riding or passing underneath a flight of the two a mass of débris falls upon you like rain. The birds are never seen to settle, but remain perpetually on the wing.

These birds are of a dove-colour, rather larger than a swift, and have the same easy flight. They generally disappear with the locusts.

There is also another large black-and-white bird, something like a stork or heron, with long red legs, which on one occasion followed the locusts down country. This bird is so tame that you may walk up to within a few yards of it before it will fly away. Strange 
to say I found these large locust-birds in the North of Africa, in Morocco and about Tangier, where they are considered sacred; and although in the wild state are so tame that they roost upon nearly every Moorish but in the country, and are never molested by the Mahometans. 


\section{CHAPTER XX.}

THE WATER SPIRIT: A LEGEND OF SOUTH AFRICA.

Tue native tribes in South Africa are very superstitious-more so than most people-and some of their legends are worthy of note. The legend of the Water Spirit is one of these. The Hottentots still believe that many of the rivers at the Cape of Good Hope possess or are governed by one of these fairy spirits. I was once stationed at the Koonap post, on the river of that name, which is rather celebrated for its spirits. I remember one fine summer afternoon being awakened from my 'siesta' by the whole post being in an uproar, which I found arose from one of the most beautiful of Hottentot Venuses having been taken by the Water Spirit while bathing in the river. The whole detachment consisted of native troops, and amongst the wives and daughters there was one called Elsie, a nymph of beautiful proportions-not 'made up,' like the fashionable ladies of the present day, but 'a gal in which there was no 'fiction,' as our American cousins would say. I only wish I could draw, in order that I 
might depict her. Her back was straight; but beyond that there was not another straight line in the whole of her composition-it was all bulges, curves, hollows, and dimples.

On this summer-day nearly all the women and lasses were bathing and washing their clothes in the river, at a flat rocky ford, with a large expanse of clear, smooth water above it. While the not fair but yellow beauties were splashing about just within and beyond their depth there was a cry of the 'Water Spirit!' and as they said, on their looking up this 'sea-cow-hole,' or expanse of water, they saw the spirit walking on the surface of the water!

Now, this Water Spirit is said to be the most beautiful diminutive female form that it is possible to imagine. In stature the spirit is not above two feet six inches high, but the proportions are perfect, the face and features lovely, and the eyes and hair exquisite; and she walks on the surface of the water, with her long hair trailing on it. The alarm on seeing the spirit was so great that all the native ladies rushed out of the water splashing and screaming in a terrible manner; and in these African climes the simple Eves do not use bathing-dresses, but wear only nature's garb. However, outside the water they are more modest; but the fright was so great that, without dressing, the greater number snatched up their garments 
and almost in a state of nudity rushed to the post for the protection of the other sex. No wonder there was a commotion in the fort; for the native women, like ostriches, fancy that when their heads are covered no one can see the remainder of their proportions. Everyone looked scared, and the cry was 'Elsie, Elsie!' But no Elsie appeared, and it was evident that the cry meant that this not 'fairest of the fair' but 'yellowest of the yellow' had been taken by the spirit.

Immediately a discussion arose as to what was best to be done. I, however, started off as hard as I could to the river, and there I found the poor creature still, apparently, struggling with the spirit. I had to plunge into the river and bring her to the shore. Whether it was that the Water Spirit did not like gentlemen I cannot tell, but after I got the damsel out of the water the turmoil in the river ceased and the expanse became as smooth as ever. I was puzzled what to do. I was in an awkward position, with the Hottentot Venus glaring at me with the eyes of the spirit. Luckily the 6 wise women' of the post were approaching, forbidding the more impressionable ones to continue their wailing, and they soon relieved me of the 6 possessed one,' as they would persist in calling her. Certainly as far as her intellect was concerned she was possessed, for in the short space of time she had become raving mad, and, as the wise women said, all owing to the Water 
Spirit. For days and nights this girl never slept; her ravings were most fearful, and all her incoherent speech was to or about the Water Spirit, and what she had seen in the fairy-like palaces under the water. I sent for a doctor, and all sorts of European appliances and medicines were resorted to. Still she remained in the same sad state; and all we could get from the wise women was 'They knew it! they knew it!' 'Knew what?' I exclaimed; and it came out that the Water Spirit must be propitiated. They say a wilful man must have his way; but I think a wilful woman must have hers, or rather the whole lot of women at the post. Have it they would, and have it they did, for the spirit was in due course of time propitiated by atonement, and the beautiful Venus was restored to her senses.

On the third day after the spirit had possessed the maiden I observed that the goats and sheep were not turned out as usual to pasture. These belonged to the old native soldiers, who, particularly at outposts, were allowed to convert their savings into 'stock,' to sustain their families. After much discussion and deliberation a lamb without blemish was selected to be sacrificed to the Water Spirit, which was done by the patriarch of the whole assembly. A procession was formed, and the lamb led to the river, where it was sacrificed on the rocks and its blood sprinkled over the running current. Then the lamb was cut up and the choice pieces 
selected from the remainder. The 'wise man' then disrobed, retaining only a girdle round his loins, and walked into the river up to his waist, when a young lad brought him the several portions of the sacrificed lamb which he placed reverently and quietly on the surface of the water and then withdrew his hands. Sometimes the portion floats up stream on the surface of the river until apparently received by the spirit, the water opening as it were to accept the atonement. At other times the portion is washed down the current at once. All these indications were watched most religiously by the assembly, which rejoiced or desponded according to the indication.

On this occasion the indications, in the minds of the people, were conclusive that the spirit had accepted the sacrifice as an atonement, and was propitiated; and the assembled relatives and friends returned to the post rejoicing; but what is more strange than all the rest is, that Elsie had recovered her reason by the time the procession returned to the post.

In this case the natives would say that Elsie had only struggled with the spirit; but they relate numbers of instances where the Water Spirit has taken her victims to the palaces inlabited by the water spirits under the water. The legend is that you must not weep or wail for those that are taken-if you only believe and wait patiently they will be returned to you alive and 
well; if, on the contrary, you weep, the bodies only are returned without life.

There are many stories current describing most minutely the beautiful palaces inhabited by the mermaid spirits under the water; and the creatures of the deep are said to serve them. Hence the 'Iguana,' a small kind of crocodile, proceed on shore at night and take chickens from the hen-roosts and eggs from the fowl-house for their fairy mistresses, while others carry back the vegetable substance with which the natives - plaster or cleanse the floors of their own huts. It is also said that the bodies of those returned to the weeping relatives have always a mark of strangulation on the throat and also of having been tied with rushes, while the relatives of those who rejoice return to a new life. 


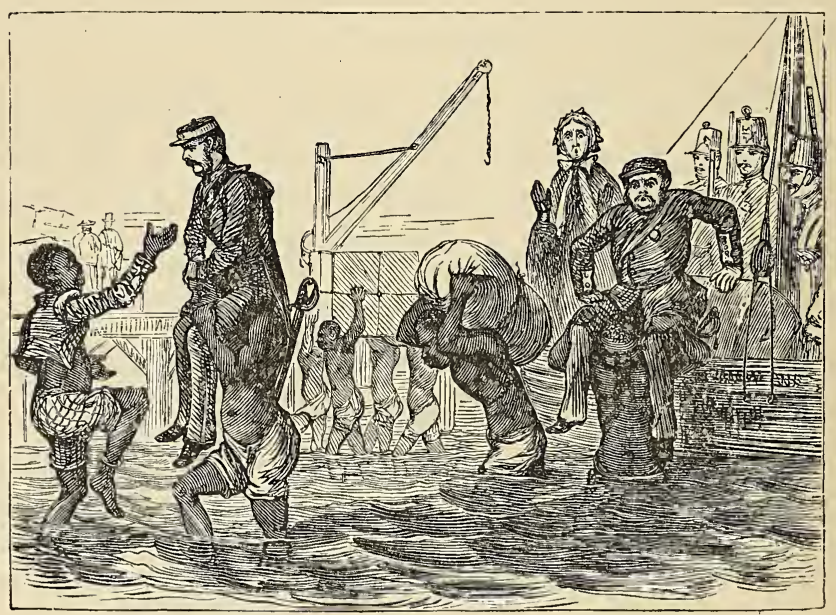

LANDING AT PORT EI.IZABETH.

\section{CHAPTER XXI.}

THE GRAND BATTUE; OR, ROYAL SPORT IN SOUTH

$$
\text { AFRICA- } 1860 \text {. }
$$

Towards the end of July 1860, H.M.S. 'Euryalus' steamed into Simon's Bay, Cape of Good Hope, with His Royal Highness Prince Alfred on board as a midshipman. It is not my intention to endeavour to depict the great demonstrations with which the loyalty of the South African colonists welcomed the Sailor Prince; my object is to get to the front, and try to 
describe that glorious day when we killed six hundred head of game, all larger than horses.

On August 6 His Royal Highness landed at Port Elizabeth, where Mrs. Fleming's beautiful house was placed at his disposal. In the evening there was a grand ball in honour of the event and to celebrate his birthday. Mule-wagons and horses were in readiness to carry the Queen's son and his retinue on to Graham's Town. It had been arranged, in concert with his Excellency the Governor, Sir George Grey, that His Royal Highness was to leave his ship at Port Elizabeth, and proceed to the Eastern Provinces of the Cape; thence inland through the Orange Free State and borders of the Transvaal Republic into Natal, and to rejoin his ship at Durban. the port of that colony.

The retinue which embarked on board the 'Euryalus' at Cape Town comprised the Governor, Sir George Grey, and his aide-de-camp, Josias Rivers, and the staff; also Lieut.-General R. H. Wynyard, his aide-de-camp, and myself. The staff of His Royal Highness included Sir J. Cowell and some officers of his ship. Several of the latter, with the sanction of Captain (now Admiral) Tarleton, accompanied the Prince on his tour.

H.M.S. 'Euryalus' proceeded from Port Elizabeth to Natal, there to await the arrival of His Royal Highness; and the General commanding, not feeling equal to the rapid and fatiguing overland journey through the in- 
terior of Africa, deputed me, as Deputy QuartermasterGeneral and next senior officer (except General D'Urban, commanding in Kaffraria), to accompany His Royal Highness through the Provinces of the Cape of Good Hope, the General himself proceeding in H.M. ship, at the invitation of Captain Tarleton, on to Natal.

His Royal Highness remained only one day at Port Elizabeth. A large concourse of the inhabitants formed his esccrt on the morning of the following day to the bridge on the Zwartz Kops, where leave was taken by many that had been at the ball the night before. I was struck by the tears shed by many a fair dame with whom he had danced, and by more with whom he had not danced, the night previous. But, as I said before, it is not my object to describe these. demonstrations.

On August 7 we crossed the Sunday's River, and halted the first night at a small inn about four miles beyond. I must here say that all the innkeepers and indeed everybody did their utmost to provide for the comfort and happiness or pleasure of England's Royal son. There is a forest on each side of the Sunday's River, and the Prince became much interested when a spot was pointed out where a monster elephant had been killed not many days before. During the day the cavalcade with His Royal Highness was so great that no one in the rear could see his neighbour for dust. 
Many horses came down, from the inequality of the ground, and it is wonderful that the riders were not trampled to death by the throng.

I must not pass over this first day without recounting the Prince's first experience of hunting at the Cape. A keen sporting man named Reid, at Port Elizabeth, had got up a hunt on the road at a place called Amsterdam Flats. Beaters and dogs had been sent on, and we certainly had some exciting sport in the way of small game. Befure we reached our first ' outspan' there was some very good coursing, and about ten head of game were shot or caught by the greyhounds merely en passant. One poor fellow who accompanied us had his leg broken at the ankle, and the Prince's kindness and sympathy were beyond measure. He did the good Samaritan by paying for his conveyance back, and for his care while in Grey's Hospital, the very building which His Royal Highness had opened the day before.

On the second day we passed on rapidly over fifty miles, and halted that night, after crossing the Bushman's River, at the Nazaar. Nothing of any great note happened, except that some of the 'sailor boys' began to complain that the horses were rough, and they fancied that the saddles were not quite so smoooth and comtortable as those in England.

On this day (August 8) we were met by a large concourse of people from Graham's Town, the capital of the 
CHAP. XXI.

Eastern Province of the Cape of Good Hope, preceded by my relative, Sir Walter Currie, and a small band of his mounted police, all on first-rate horses.

Sir Walter had brought his favourite charger Lancer in hand for his Royal Highness to ride; and as we all were on comparatively tired horses we had a hard time of it from Quagas Flat on to the Nazaar, where the camp was really formed for the night, and not at the Bushman's River, as noted on the map. The distance travelled this day was more than fifty miles; so that it is not to be wondered at that those unaccustomed to high trotting horses were a little worn out.

On the third day (August 9) we entered Graham's Town amidst the rejoicings of the whole of the inhabitants of that loyal and thoroughly English city. Vast numbers of the people came out for miles to meet the Royal Prince, and the English hurrahs resounded and were re-echoed by the cliffs, mountains, and valleys of Howison's Poort for miles before his Royal Highness reached the capital. After passing the toll-bar and reaching the head of Godwyn's Kloof, the cavalcade halted, and the Prince had a good view of the home of England's British settlers of 1820 -men who had laboured long against adversity, but who, from that English pluck and indomitable perseverance which animates the race, had overcome all early difficulties, and were now resting in abundance and riches. 
At the first triumphal arch the Royal Prince was met by the Mayor and chief dignitaries of the city, and loyal addresses were presented from love for Her Majesty and respect for her sailor-son.

This 9th of August was a great day for Graham's Town. Every soul was out and rejoicing, the Englishman, Hottentot, Fingoe, and the Bushman all vieing with each other to do honour to the Prince. The roar of cannon, the parade of troops and banners, and, above all, the display of bright eyes, added grace and brilliancy to the homage paid to the offshoot of the great country.

Addresses were presented from all denominations and classes of people; and towards evening his Royal Highness held a levée, at which the chief inhabitants, both ladies and gentlemen, were presented to him. In the evening there was a grand ball given to the Prince; and Mr. H. S. Blaine, the chief merchant of the city, kindly lent his large new store for the occasion. The hotels were all full, and some of the royal suite were welcomed at private houses.

At the ball there was much fun arising out of the rivalry for the Royal Prince's attentions, more particularly between the two leading ladies of the province; but the palm of honour was carried off by Lady Currie, the wife of the gallant knight so respected, so dreaded, and so beloved on the Frontier. One fair dame in the ballroom enquired of His Royal Highness after his 'mother;' 
and the Prince replied, with a most courteous smile, that 'Her Majesty the Queen' was quite well.

On the 10th His Royal Highness halted at Graham's Town, and the day was devoted to laying foundationstones of public buildings, receiving addresses and public deputations, visiting the principal places, and paying some royal visits, one of which was to Oatlands, the park and residence of Sir Walter and Lady Currie. As His Royal Highness entered the grounds he passed under a beautiful arch made of evergreens and wild flowers; and on one of the pretty slopes facing the house the Prince planted a young oak tree, which has been cared for in remembrance of his visit ever since. Sir Walter fenced off some acres of ground round the spot, and had the tree carefully tended and watered for years. It is now a gigantic oak tree, and under its shade I have often rested and contemplated the past and future of that great country of South Africa. Currie's grounds are always open to the public. And on all public holidays you may see thousands of people enjoying their picnics in all directions, and a crowd always round the Prince's tree. Alas! the excellent and benevolent owner of the property has since passed away from amongst us, but his amiable widow stili keeps it up as it was in his day.

From Graham's Town a fresh start was made for Fort Beaufort, British Kaffraria, and on to the frontier 
of the Colony, before proceeding inland to the interior of Africa. The Lieutenant-General Commanding did not accompany His Royal Highness further eastward on his tour; but his Excellency and Captain Tarleton proceeded the next day to the Cowie River mouth and opened the harbour works, naming the place Port Alfred.

On August 11 we had a long and rather tiring ride of fifty-six miles. Before reaching Fort Beaufort the horses became leg-weary from the pace, and two or three of the party got falls. Lord Charles Scott bad one so bad that he was unable to proceed inland with the party. At Beaufort there were festivities, dinners, balls, and rejoicings ; but the Royal Prince, Sir G. Grey, and all the party proceeded next day to the town of Alice, which is prettily situated on the Chumie River, which divides the old colony from British Kaffraria. From Alice we moved forward early on the morning of the 13th, and diverged from the main road to visit Heald Town mission station, one of the native industrial schools inaugurated by Sir George Grey for the improvement of the native races. These establishments have done more good than all the previous missionary schools, for with education was combined the teaching of trades and the culture of land. It is a system that I would earnestly recommend to be adopted at Natal; and a few thousands a year granted by England for the purpose would more than be repaid in the future. 
The second halt on this day was at Middle Drift Post, on the Keiskama River, and in the location of the Kafir chief Kama. After a short ' off saddle' we crossed the beautiful river of clear crystal water, then passed the twin hillocks called by the natives the Amabella, or Bosoms; the Debe Flats, at the foot of the Taban Doda, or Man's Mountain, under which Fort White is situated; then through the Debe Neck over Kometjes Flat, and on to King William's Town, the military and civil head-quarters of British Kaffraria. At King William's Town His Royal Highness only halted one night, and was entertained by the chief military authority. Triumphal arches had everywhere been erected. The Prince was received by the Chief Commissioner, and many Kafir chiefs were presented to him, as also the magistrate and the principal residents.

On the 14th the Prince reached Stutterheim, the head-quarters or chief settlement of the German military settlers who proceeded to the Cape and British Kaffraria under Baron von Stutterheim after the Crimean War.

On the 15th we made a long day's march on to the branch of the Kie River to a village called Tylden, so named after a brave officer of the Royal Engineers who fell before Sebastopol. Our morning halt was on the Thomas River, where the first group of Kafirs were collected, and were photographed by Mr. Yorke, who 
accompanied the Prince from Cape Town. Sandilli, the great Kafir chief, was also presented to His Royal Highness at the Duhnie Post (Stutterheim), by his Commissioner, Mr. C. Brownlee; but he did not appear at all to advantage. He is not an imposing-looking Kafir; and his being dressed in European clothes detracted much from his national character.

On the 16th we moved on to Queen's Town, being first met by the mounted Burghers of the District, drawn up under their field-cornets and field-commandants; and further on we met a large body of natives from one of the reserves, who had come, under Mr. Magistrate Warner, to pay their respects and tender their allegiance to the Queen of England's son.

We passed on and entered Queen's Town in clouds of dust; and it was well for those who were in immediate advance with the Prince, for no others could see a yard before them. At Queen's Town there were again great demonstrations of loyalty and rejoicing, deputations, presentations, \&c., \&c.

I must also mention one notable circumstance of the day. Soon after leaving Tylden we found a small band of natives drawn up, who had crossed over from the other side of the great Kie River, under a guarantee of protection, in order to make intercession with the Prince and the Governor, Sir George Grey, for pardon. These men were rebel Hottentots who had been in arms 
against the Colony in the last war. The Royal clemency was graciously extended to such of them as were not deserters from the Cape Mounted Rifles or leaders in the rebellion.

On the 17th we travelled above fifty miles, and halted for the night at a farm-house, having had one 'off saddle' at a mission station under the Hanglip Mountain, where the school natives were assembled and sang a hymn.

On the 18th we reached Burgher's Dorp, a Dutch village, in a rich sheep-farming district under the Sneuw Berg, and put up at Mr. Mosenthall's hospitable dwelling.

On the 19th we again moved on, and that night reached Aliwal North, situated on the banks of the Orange River, which is the boundary of the colony of the Cape of Good Hope.

Up to this point the military authorities had rendered every assistance to the Royal progress. Mulewagons and camp equipage had been furnished; Cavalry escorts from the Cape Mounted Rifles had been detailed, and troop-horses provided to ride. Mr. Commissary Hall had charge of the transport, and Lieut. Wyatt commanded the escort; while I, as Deputy Quartermaster-General, carried out the General's instructions generally.

Sir Walter Currie and myself had been especially 
invited by His Excellency Sir George Grey, the Governor, to accompany the Prince on this tour and on to Natal; but it was intimated to us that we must do so at our own expense, as the cost could not be defrayed out of public funds. Sir Walter, therefore, fitted up a private wagon with eight mules, and started from Graham's Town direct for Queen's Town, where he joined us; but by the time we reached Aliwal North some of the mules were so done up that we had to purchase others to replace them. We had also to purchase fresh shooting horses. Sir George Grey had previously in anticipation despatched riding horses and horse and mule wagons from Cape Town, and these fresh materiel were waiting for the Prince's party at Aliwal North; and it was therefore a little hard on Currie and myself to keep up with the fresh teams. How-. ever, I will explain how we did this as I go on.

At Aliwal the Prince was met by Mosheish, the great chief of the Basutos, with his sons and a number of followers, who came from his own territory, beyond the Orange and Caledon Rivers, to pay friendly greeting; and also by a-large number of natives under British rule from the Reserve, under Mr. Austin, the native agent at the Witt-berg, to tender allegiance.

On August 20 His Royal Highness crossed the Orange River and passed into the Orange Free State; and making a long day, reached Smithfield about dark 
the same night. This day we also crossed the Caledon branch of the Orange River. The Prince put up at a house taken for the purpose, while Currie and myself were entertained by Mr. Coleman. During the night we had great bargaining with a Dutchman named Pienaar for a favourite shooting horse, which was presented to the Prince the next day. It was a grey, 'trippler'-one of those rare horses of the Cape which amble along and carry.you as if you were sitting in a chair.

On the 21 st and 22 nd we camped out, and had a very jolly time of it. A small marquee was generally pitched for us to dine in, and afterwards formed a sleeping-place for some of the party. Sir George Grey and Sir John Cowell had a tent each, the Prince always sleeping in his little travelling-wagon, which he shared with a midshipman comrade. There was always a general camp-fire; but Currie and myself invariably had our own, and it was the general resort after dinner.

During these two days we passed through a good deal of game, and single wildebeasts (gnus) were killed by different huntsmen, besides numbers of smaller antelopes, also bustards, koorans and partridges, \&c.

On August 23 the cavalcade-or ' trek,' as it should more properly be called (as combining wagons) reached Bloom Fontein, the capital of the Orange Free State. A royal salute was fired from the old fort, which 
once belonged to England, and which she so unwisely gave up when Sir George Clerk was sent out as a Special Commissioner to relinquish that valuable territory to the Dutch emigrants. The Dutch Burghers came out in procession to meet the English Prince; and as there were many Englishmen in the place, much loyalty was shown. The royal standard of England was frequently displayed, and arches were erected and banners stretched from house to house. I am sorry to say one poor fellow had his arm blown away in firing the salute. But single guns and musketry were being fired off all night, as is the Dutch manner of keeping jubilee. We were all of us most hospitably received with every demonstration of cordiality and good will; and many both Dutch and Fnglish former British subjects regretted that they were not welcoming the Prince to one of his own provinces instead of to a Dutch State.

Some days before we arrived at Bloom Fontein an express had been sent on, and a large body of natives from the tribe of 'Morocco,' a native chief, had assembled in, or rather had encircled, the vast plains in the neighbourhood of Reit Vley, the property of Mr. J. H. Baines, one of the great hunters of South Africa, who had settled down in the Free State as a farmer. This gentleman had invited the royal party to a great hunt on his farm. 
The extensive plains in the Free Stateare intersected here and there by belts and cross-belts of mountains, with only gaps between, through which the countless herds of large game pass from one plain to another. For days before we arrived the natives had been concentrating from distant points towards Reit Vley, leaving men in the 'several necks,' as they passed on, to prevent the game from escaping back to the plains, from which they were being driven towards a common centre.

Early on the morning of the 24th His Royal Highness and the shooting party of twenty-five guns in all started for Mr. Baines' farm, which caused us to diverge nearly six miles from our route. We reached Reit Vley about eight o'clock, and were provided with a sumptuous breakfast. During all this time we saw masses of game closing in from all directions.

Our first sport was, however, to have been a Lion, and we made for a hill where it was supposed the monarch of the plains would be found; but I am sorry to say we were disappointed; he had managed to escape from his lair during the night; and as time was precious, we had to give up the lion for less noble game. Herds upon herds of large game (all of the antelope species) were passing us, and the battue commenced by the Prince bringing down a great wildebeast, or gnu. This ferocious-looking beast turned on His Royal 
Highness on being wounded, and received a second ball, which rolled him over. This was the signal for a general onslaught.

The hunting party advanced up the plain in extended order, a few yards apart, and masses of game kept breaking through as the pressure of the coming streams of antelopes, quaggas, zeebras, bles-boks, eelands, ostriches, hartebeasts, wildebeasts, koodoos, \&c. \&c. came pouring on towards us, and, checked by. our fire, commenced to whirl. The plain in which we were was of vast extent-I dare say nearly a hundred miles in circumference-and the whole of this extent was one moving mass of game. The gaps between the mountains on all sides of this plain were stopped by a living line of men, and we were in the midst of this whirling throng firing at great game at not twenty-five yards' distance as fast as we could load. The Prince fired as fast as guns could be handed to him, for Currie rode on one side and $I$ on the other, and we alternately handed guns to him as he discharged his own. As the circle narrowed there really was considerable danger from the game breaking through, for when a stampede took place so much dust arose that you were in danger of being trampled to death. It became very exciting to see great beasts larger than horses rolling over from right and left shots not ten paces from you, and also charging down with their great horns lowered as 
if they were coming right at you and then swerving to one side or the other.

All this time we were working back towards Bloom Fontein, as it was Sir George Grey's intention to move on a stage on the journey the same afternoon. During the great slaughter of the day the circle of natives was closing in; and the mass of game became so dressed together at last, that the Prince and Currie took to their hunting hog-spears and charged into the midst, driving home the 'Paget blades' into the infuriated animals. It was at this point of the battue that Sir George Grey rode up and directed us to desist. He was a keen sportsman himself, and had been committing great slaughter up to that moment. This great destruction of 600 head of large game was no wilful waste of God's creatures; some thousands of natives had been employed to drive the masses together, and they had brought 600 pack-oxen to carry away the carcasses for their winter supply of food. Their mode of preserving the meat is to cut it into thin strips, about the size of your finger and to hang it over bushes or on strings supported by sticks; the sun and rarefied air upcountry will dry it in a day or two; you can then pack it away in a dry place, and it will keep for months or even years, the meat retaining all its nutriment.

We selected some of the choicest of the game to be carried back to our wagons, and many trophies of heads, 
horns, tails, and skins were also reserved. All these were intended by Mr. Baines to be preserved for His Royal Highness; but I am sorry to say they never reached the Prince, although they were sent to Fngland in charge of a South African traveller.

Six hundred head of large game were shot on this day, besides numbers speared by the natives, and most of the sportsmen looked more like butchers than sportsmen, from being so covered with blood. His Royal Highness and Currie were red up to the shoulders from using the spear. I cannot myself boast of many trophies, as I generally handed my double gun to the Prince as fast as I could load it; nevertheless I could not resist now and then bowling over a couple of great antelopes as they whirled past me. It was a very exciting day, and were His Royal Highness to live for a hundred years I do not believe he could ever see such a scene again, for the game in South Africa is fast disappearing. At the time I am speaking of (1860), it was still to be seen in great masses, and what were called the 'trek-boks' were as much dreaded by the farmers as the Jocusts. It is generally during the time of drought in the interior that these 'trek-boks' migrate southward, devouring every blade of grass before them, as the locusts do when they come from the north; standing corn, gardens, \&c., are all devoured; but both beasts and locusts form food in their different ways for the 
native tribes, who first dry them and then lay them up in their stores.

Currie and myself stayed some time with our old friend Baines, but the Prince and the Governor returned at once to Bloom Fontein, and moved on with their camp to the sources of the Modder River.

At Baines' homestead we were surprised to see a lot of tame young ostriches running about, and he told us of the novel mode by which they had been hatched. Some time before we arrived there a fine fat housekeeper of his was laid up with rheumatic fever, and he conceived the idea of hatching some ostriches by the heat from her body; fourteen eggs were therefore placed in her bed in rows on each side and about her, and after the due time of incubation the little birds began to break their shell; then forth came the little unfledged rascals that we now saw grown to such a size. Baines was rich in feathers, and presented us each with a bundle. We had a great laugh over his 'patent incubator,' who was exhibited for our special benefit. Since then all sorts of devices have been tried to hatch the young ostriches, but there is nothing like Dame Nature, or Dame Housekeeper. Ostrich-farming is now becoming a great domestic culture in South Africa, some extensive farmers rearing 200 birds in the year, each being worth about 50l. sterling. It is well that they have been domesticated, otherwise they would very soon have disappeared, 
for in the wild state you must shoot the bird to get the feathers; but now they are driven into pens and picked or rather clipped, though the feather is not quite so good in the tame as in the wild state.

Currie and myself after returning:to Bloom Fontein, moved on with our solitary mule-wagon, but did not reach the Governor's camp until late in the night.

On the 25th we all moved forward early, had a long day of over fifty miles, and halted for the night short of Wynberg, the second town of any importance in the Free State, which is situated in a prosperous pastural district. During the day we passed through vast herds of game, consisting of hartebeasts, wildebeasts, zeebras, bles-boks, \&c.; and as the Prince was constantly diverging from the road in pursuit of this game, the actual distance travelled each day was very much more than that shown by the map.

On the 26th we moved on into Wynberg, where His Royal Highness was received with much cordiality by the Dutch, German, and English residents. A royal salute was fired from improvised cannon, and Dutch sporting guns were perpetually being fired off. The country we passed through before reaching this town was more undulating, and studded with trees and bush.

On the 27th we moved a stage forward on our journey, followed by a goodly number of Dutch 
farmers who had collected, knowing their President, Pretorius, was expected to meet the Prince while en route that day. The President of the Free State had been to the neighbouring Transvaal Republic, and was on his return; hence he had not yet met the Prince. We had not proceeded far from Wynberg before we met a cavalcade of Dutch Burghers, with President Pretorius at their head. England's Royal son and the Dutch President met most cordially, and when the latter addressed Prince Alfred as 'our Prince' there was general applause from both cavalcades. Some time was taken up in pleasant conversation; and when the two chiefs parted His Royal Highness presented the President with one of his wagons. We then continued our ' trek' for some distance and encamped for the night.

On the 28th we again fell in with vast quantities of game, and one fine wildebeast shot by His Royal Highness was photographed by the side of his wagon while we were out-spanned for a mid-day halt. During the whole of this day we were shooting right and left of the route, and many head of large game fell to the Prince's rifle. Sir George Grey was also most keen, and being well mounted, did good execution. Currie or myself generally kept by the side of the Prince. At one spot, dismounting under cover of a brow, we walked up to it, found that the plain was covered with game, and a single great bull wildebeast facing 
us at about 200 yards. His Royal Highness took aim at him, and brought the big beast down most splendidly.

The wildebeast is a most ferocious-looking animal, and appears to be twice the size he really is. He has a mane and deep dewlap, which help to magnify his size.

On the 29th we had another long day, and with it much shooting. You saw everybody racing after herds of game in all directions, and the great chance was to head the game where they crossed rivers or creeks, for where the leading one crossed he would generally be followed by the whole herd. We generally galloped in a body, dismounted abreast of them, and then there was a regular fusillade. You can generally hear when the balls tell from the 'thud' sound, but you cannot see the effect by reason of the clouds of dust. On this occasion only one great beast lay rolling on his back, but as the herd passed on we saw several falling to the rear, and each of us singled out one of these wounded ones. The Prince followed a great bull, who turned on him, and I watched the result with much anxiety. A Cape Mounted Hottentot soldier always followed the Prince, and on this occasion diverted the fury of the wildebeast, which first charged at one and then at the other ; and as it was difficult to shoot him from horseback His Royal Highness most pluckily dismounted not twenty yards from the animal and bowled him over 
with his second shot as he came charging at him. The beast had only previously received a wound in the leg. The head and tail of this African bison were carried to the camp as a trophy; and as the spring-bok is considered the best eating antelope, we also carried to the wagons a fine one which the Prince had shot.

Currie and myself had a good deal of hardship to encounter on this trip. We were accompanying the royal party on the invitation of his Excellency the Governor-as it were his private guests-so we had to find our own way. This would have been nothing under any other circumstances; but we were travelling in company with Government wagons and horses, which were fed every night with forage bought by the Governor, he having the preference in buying before anyone else), or from hay carried in hired wagons where it could not be bought, while we with our one small mule-wagon could not carry forage. Currie and I had therefore every night to 'steal a march' on the Governor, and this we did in the following manner. We generally all dined together in the Governor's marquee, and afterwards adjourned to the camp-fires. During this time our span of mules and riding horses would be kneehaltered and sent out to graze in charge of the wagondriver or leader, those of the Governor's camp being tied up and fed on corn. Starting so early as the carnp did in the morning, all hands had to get to bed 
betimes-and it was then that Currie and I would quietly in-span our wagon, saddle up the horses, move on for three or four hours of the night, and when we did halt again turn our horses and mules out to grass, taking turns to watch them until daylight-many nights with lions roaring not far from us. At dawn of day we would again in-span, and move on till about nine or ten o'clock, when we would unharness the cattle and prepare our breakfast, or rather morning meal. The Governor's camp would overtake or pass us while so halted, and I think the Prince enjoyed nothing more than the cup of coffee, or bit of 'carabenatje' which was always ready for him on these occasions.

While at our morning out-span of this day, Sir Walter and myself had some glorious sport all to ourselves. We had crossed a river just below the junction of two branches. Our route had been skirting the boundary-line of a portion of the Basuto Territory, and a large native hunting party was out after the game to our right. All at once we saw masses of game pressing down between the two branches of this river, and we had only time to snatch up our guns and head the stampede, which had to pass the river at the spot where we stood. Had there been breechloaders in those days we might have killed any quantity of great beasts; as it was we killed more than both camps could consume or carry on. 
But to continue. On the 30th we moved on and halted a little short of Harrismith - not at the town itself, as is marked on the map. I know this well, from the circumstance that our wagon reached that town by the morning ' trek' before the Governor's camp came in, and I by chance bought the only stock of forage in the place. Harrismith is the last village in the Free State. The road thence crosses over the Dragonsberg range of mountains, and drops down into Natal, where we knew there would be little or no forage, and the grass at that time of the year is all burnt up by grass fires.

This caused a great dilemma with His Excellency the Governor's caterer, an officer who well knew how to take care of his horses and miles; he therefore came to Currie and me, and we made a compromise about the forage. I had bought it all-300 bundles-but with our small wagon there was not room to carry on what we required, and it was agreed that Rivers was to hire a wagon and bring on a sufficient supply to give us 100 bundles of the oat-sheaves at our night's halt. We had a long and difficult day over the great mountain range, and pitched our combined camp at the foot of it, in the colony of Natal. After we had dined and were sitting round the camp-fires, the Dutchman's wagon arrived with the oat-hay; but behold! instead of 300 bundles, only 100 bundles came in all! Our Hottentot leader and driver had been desired to go to the wagon 
and get our share; but they were told that we were not to have any portion of the forage, as there was not enough for the Governor's horses and mules.

Currie could not stand this, and without saying a word he went off himself to the wagon and took twentyfour sheaves, on which our friend Rivers went to Sir: George Grey and complained, but did not tell him anything about the arrangement and agreement that had been made about it. Of course the Governor was very irate. It looked like mutiny in the camp. He came to our fire, took me by the arm, and we walked some distance out of camp ; then commenced such a storm as I have seldom heard. After he had quite done I told him how the case stood, and he not only exonerated Currie, but ordered that we were to have our full share of the forage, and we got a third of the whole supply. We did not, however, feed our cattle with this oat-hay. We watched our mules as usual the whole night, packed the oat-sheaves into our wagon, and for the remaining three nights before we reached Pietermauritzberg gave back a portion of this very forage to feed the Prince's and the Governor's own horses. It is well we did this, for every blade of grass in the country was burnt up, and there was not a vestige of forage to be got on the way. Our own mules knocked up, and only reached Pietermauritzberg the day after the Prince arrived. Luckily we were met by Commandos mounted escorts from the 
capital, and private friends carried Currie and myself on.

The very day of our crossing over the mountain into Natal we met on the slopes of the Dragensberg a large multitude of Zulus drawn up under the resident magistrate and their own chief, the same Langalibalele who is now so much talked about. And what is also a strange coincidence, we moved the next day (September 1) to Colenso, a township so named after the Bishop. On the 2nd we proceeded on to the Bushman's River, and on the third reached Pietermauritzberg.

The day we entered Pietermauritzberg was one of those days at Natal when it blows a perfect hurricane. The country is very dry and burnt up at this time of the year, and the clouds of dust along the roads are something terrible. About twelve miles from the capital the road crosses the Umgeni River at a ford about 100 yards above the waterfall of that name. These falls are 320 feet high, and the body of water is very great. On this day the high wind caught up the spray at the falls and threw it back in a circle over the ford high up above our heads, thus forming a complete rainbow, with all its varied and beautiful colours -it represented a grand triumphal arch for His Royal Highness to pass under, and one very appropriate for the Sailor Prince.

At Pietermauritzberg there were great rejoicings 
-royal salutes, parade of troops, addresses presented, and no end of excitement. Here His Royal Highness halted on the 4th; and there was a great assemblage of Zulus, under Mr. Shepstone, the Secretary for Native Affairs, to pay their homage to England's Royal son, and to perform a war-dance in honour of the visit.

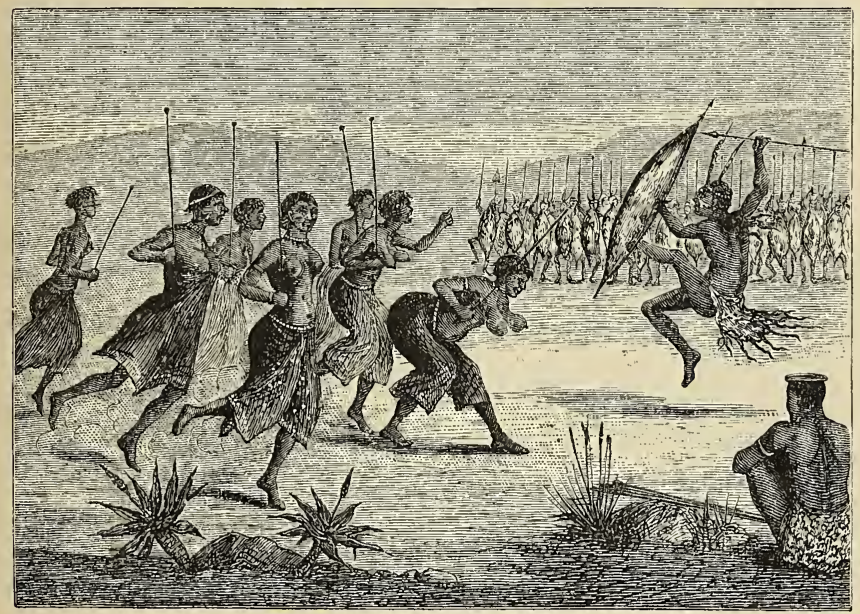

ZULU WAR DANCE.

This dance was very novel and exciting to look upon. Some thousands of Zulus were assembled in their war-plumes, with their shields, assaigais, stabbingspears and battleaxes. These warriors generally form in mass in the shape of a crescent with the horns thrown forward ; they appear to form a complete solid wall, from the shields, which are about five feet high and two 
and a half broad, being so placed as to form a front of hide-armour.

The Zulu tribes have all sorts of war-songs; they are most regular in chant and melodious in tune, with motions and gesticulations very minute and simultaneous, the effect of which is most stirring and martial.

After they had recited these war-songs a sham fight took place. In a moment the front row of shields was held up over their heads, and a perfect cloud of skirmishers started to the front from among those who had formed up behind; these darted about right and and left, jumped into the air, and went through all the antics of so many devils. They advanced and retired as though the tide of battle was swaying them all the time, using their spears and battleaxes as if stabbing or cleaving the enemy, and their shields to parry or ward off the counter-blows.

The great mass was all this time advancing in support of the skirmishers, shouting their war-songs, and with a tread so regular that it made the very earth vibrate.

The Zulu war-dress is most fantastic, but at the same time must picturesque. First, round the ankle there is a fringe of long hair from a bullock's tail; immediately above the calf of the leg there is another, which hangs downwards nearly to the first; the knee and tendon Achilles are quite free; round the waist is 
a girdle of wild cat or monkey tails strung so close together that it forms a complete kilt; round the neck is another fringe of cow-tails, and innumerable strings of beads of all colours and descriptions. The arms are similarly protected with cow-hair round the arm above the elbow and also above the biceps muscle; some have ivory bands round this part, to indicate rank; the head likewise is fantastically dressed with stuffed rolls of otter-skin-black ostrich feathers and tufts of the same of all shapes and sizes, crowned by long feathers stancling upright or inclined at various angles. On the whole the Zulu looks a most formidable warrior.

The greatest horror of all the scene was presented by the 'Prophetesses,' a number of whom accompany the warriors into battle, and follow them in the field to kili the wounded. These she-devils were the most diabolical of human creatures, ugly and wrinkled to a degree, and they had attached to them all the 'bewitching' symbols of their craft in the shape of fishes' bladders, reptiles, and filthy charms. They carried long knives and battleaxes only, and you saw them going through all the mockery of killing wounded men on the field. It was most shocking to look at, yet well worth seeing as a novelty.

After the sham fight the Zulus were again drawn up in mass, and a second time presented a native salute to the Prince. This is done by simultaneously raising 
the right hand above the head and all exclaiming 'Biatt!' at the same moment; it means King or Father, and has a striking effect.

The remainder of the day was devoted to seeing what there was to be seen and holding a levée, at which all the chief inbabitants were presented to His Royal Highness. In the evening there was a grand ball given by the acting Lieut.-Governor, Colonel Williamson, of the 85th Regiment, and the Mayor and Corporation of the city. It was a grand day and night too, for Pietermauritzberg, for not many of the inhabitants had ever before seen Royalty. Almost all classes attended the ball ; and I must relate a second funny story about one of the Prince's partners. After a dance he was walking about with a lady on his arm who had no doubt during the day heard a good deal about 'His Royal Highness, but did not quite know how to address him personally, so to abbreviate what she had heard kept calling him 'My Highness.' The Prince was much amused at this, and I am afraid rather led her on to repeat the title for us to hear.

During this day our wagon came in with the tired mules, and Currie and I at once started off some Zulu carriers with a quantity of hartebeast and bless-bok meat, which we had brought on from the Free State, to Durban, a distance of sixty miles, to be sent on board the 'Euryalus,' for the officers and sailors to partake of 
our game. The Zulus reached Durban before we did the next day, and we found the meat on board.

On September 5 His Royal Highness left Pietermauritzberg, and the same day re-embarked on board his ship at the port of Durban, in Natal, making exactly thirty days since we all left the ship at Port Elizabeth, during which time Prince Alfred must have ridden (including the hunting) nearly 1,500 miles. At Durban there were the same demonstrations which had characterised his reception by all Her Majesty's subjects in South Africa. We were not sorry to get on board after our long ' trek.'

I must not forget to mention that Mr. Yorke, of Cape Town, also accompanied His Royal Highness as an amateur photographer. He started with us overland with a cart and four horses, carrying all his paraphernalia in it; and I arr indebted to him for some of the photographs from which the illustrations are made in this volume. It is wonderful how he kept up with us, for Currie and myself had several times to purchase fresh mules here and there to replace some left behind, and we had only on one or two ocrasions to help Mr. Yorke to get along.

On September 6 we were bowling along in the good ship 'Euryalus' at twelve knots. The Prince had laid aside his Princeship, and was again the midshipman on board. We landsmen were paying tribute to 
Neptune, yet it was very pleasant. After the first day or so I had time to look through my ostrich feathers, and to select parcels as parting gifts. In all we were a large party ; and when we (the soldiers and nonsailors) had got over sea-sickness we did ample justice to the captain's hospitable board. His Excellency, the Governor and the Lieutenant-General Commanding were also on board the ship, returning to Cape Town.

It did one's heart good to see the Prince performing all the duties of a midshipman with his brother ' mids,' early in the morning on deck, without shoes or stockings, and in water up to his ankles, directing the sailors washing decks.

His Royal Highness would again take his superior station in the evening at the dinner-table. On one occasion we had a great laugh, and the Prince enjoyed the joke as much as anyone. One of the military authorities at table was a little deaf; and the hẹad steward on handing round the wine said to him, 'Hock or Sauterne, sir?' 'What!' exclaimed the soldier, 'a rock astern?' and almost jumped from his chair. The gallant commander of the ship took up the joke, and at once said, 'Put the ship about!' Now, we landsmen were somewhat startled at this, seeing that it was adding danger to danger. However, the hock was very good.

My friend Currie was if possible a worse sailor than myself; but about the second day 'he came to the fore,' 
and the day after he astonished the ship's company by running up the shrouds, as I think they call those ladderlooking ropes extending from the ship's side to the mast. The sailors were looking on with much interest and winking at each other. My friend had got about halfway up, when we saw two great big fellows like ouranoutangs running up quietly behind him. When he got near the 'lubber's hole' he knew what they were at; and as he was not a man easily to be 'done' he saw his chance, and affecting to go through the hole, he said 'Get on, get on,' and the two sailors climbed over that part where you appear to be upside-down. At this moment Sir Walter gave them the slip and commenced to descend as rapidly as possible. There was a shout of warning from below, and the two sailors followed him down like monkeys, and would soon have overhauled him; but he let go the ropes and slid down before them like lightning. He would have gone clean into the sea had he not been caught by Captain Christian, who was watching the whole proceeding from the ship's side. We all shouted with delight, and the sailors hissed at their two companions for being outdone by a landsman. Good-humour was, however, restored in the evening ky. Currie's paying his 'footing;' and so becoming, 'free of the ship,' as I think it is called.

The two sailors did not get over their defeat or hear the last of 'being done' for a long time. 
We had a most agreeable passage to Cape Town, where we parted from His Royal Highness with those feelings of respect and loyalty inherent in all Englishmen, but increased in our case by the knowledge and experience of the Prince's manliness and courage in the hunting-field.

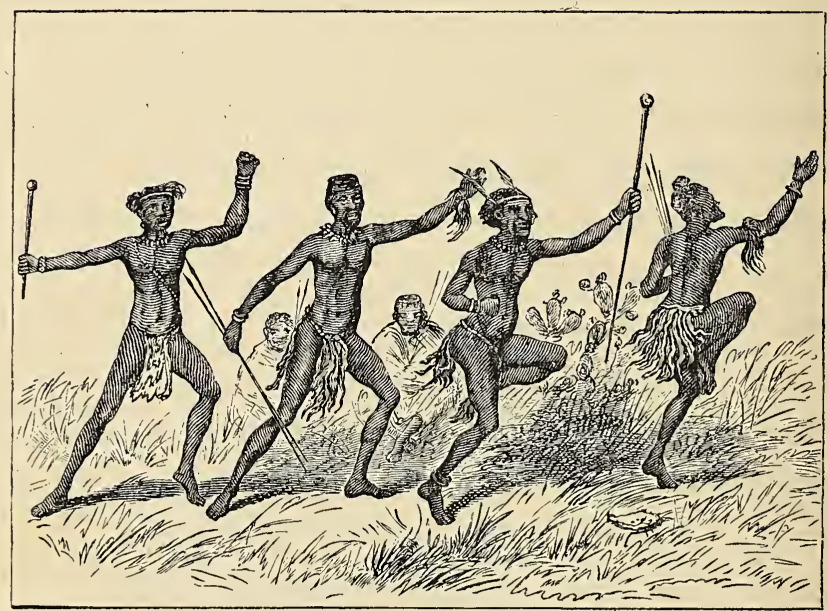

ZULU MEN DANCING. 


\section{CHAPTER XXII.}

\section{A LION-HUNT: NATAL, 1865.}

While Lieutenant-Governor of Natal, in 1865, I had occasion (in fact, it became my duty) to proceed to the north-east border of the Colony, in order to allay the excitement amongst the Dutch farmers caused by the Basuto inroad into British territory. I first proceeded to the banks of the Tugela River, at Fort Buckingham, where I was met by a large body of Zulus, assembled to demonstrate their loyalty to the Government. On that day there had been a tiger-hunt, and a fine skin of a fresh-killed tiger was presented to me. This tiger was in the habit of carrying off the goats from one of the kraals, and the hunt was got up to kill him Dogs had brought the beast to bay, and the Zulus were closing on him with spears; there were some few guns, and one shot had wounded the tiger, when it made a spring on to one of the men and killed him on the spot before receiving its death-wound. After crossing the Tugela River higher up, we passed on towards Newcastle, between that river and the Buffalo River. 
I was accompanied by Colonel Dunne, 99th Regt., Dr. Cattell, my private secretary, and a small escort of Cape Mounted Riflemen, and also by my two daughters, with their maid Verendah. We travelled on horseback; but the ladies sometimes drove and slept at night in the spring-wagon built for His Royal Highness Prince Alfred, and given by him to the Natal Government in 1860.

We passed through vast quantities of game en route, and had shot almost all descriptions, but had seen no lions. On arriving at a farm-house one afternoon we saw a splendid lion-skin stretched out to dry: the lion had been killed that morning, and the sight of the skin of course excited our imaginations. On my expressing a wish to show my friends some lion-shooting (for I had myself been at many lion-hunts before), the Dutchmen volunteered to make up a party to proceed on the following day to the mountain where the lion had been killed, and where they assured us we should find the lioness. We accordingly started at daylight next morning, reached the mountain, and pitched our camp just at dark, having passed through herds of large game, shooting hartebeasts, wildebeasts, zebras, quaggas, bless-boks, \&c.

All night long we heard the lioness roaring for her mate, and at daylight we sent scouts round the mountain to see that she did not escape. The Dutch Burghers had 
brought a couple of ox-wagons with them, and my party also had wagons and tents; these we sent on, with the ladies and the cook, to a stream in advance, with order to pitch camp and prepare breakfast for us, while we men made for the foot of the mountain.

As we appoached we found carcasses of animals killed by the lions, in all stages of decomposition. We despatched a party up the mountain to try and drive the lioness down; whilst a party and myself skirted the hill about half-way up. It was strange to see the long grass all trodden flat around the large thorn-trees, where the lions had been reclining in the shade to escape the heat of the day.

Presently one shot was fired on the mountain, and the scouts were seen riding and pointing in a particular direction. We made for the spot indicated, and found that the lioness had broken cover from the mountain, and had taken shelter in some long grass about five feet high, between two dry gullies which led down from the mountain until they joined together some distance on the plain below.

It now became necessary to call a council of war, to appoint a captain of the hunt. There was a fine old Dutch lion-hunter present, and I named him; but my old comrades of former Cape Kafir wars declared that I (His Excellency, as I was called) should lead them to battle. There was no gainsaying this; so after cautioning 
the young Boers who were present that if any of them 'turned tail ' in the moment of danger we would shoot them instead of the lion-which made their leather breeches shake in their stirrups-I decided that we should muster at the narrow or wedge end of the long grass and work up towards the mountain, extending our line as the surface became wider. We had half-a-dozen common farm-dogs with us, which worked on in advance. All at once, as we approached the centre of the space between where we started from and the mountain, the dogs ran back upon us, howling, with their tails between their legs; and as they turned after reaching their respective masters pointed to a common centre, at a spot were the grass was double the height of the remainder (this fertility being caused by the spot having been an old cattle-kraal. The dogs thus indicated where the lioness was; and calling in the extended line of huntsmen, or skirmishers, to use a military phrase, we advanced on the lair in a compact body. When we had approached to within about fifty yards of our glorious enemy, the Dutchmen, one and all, came to a stand, and you heard the exclamation of ' Myn got, eet is gevaarlyk!' and not one yard nearer could I induce them to go. In vain I declared that we were five-andtwenty strong, and enough to face any lion; but move they would not-they declared that their mode of shooting a lion was to approach to within a certain distance, 
dismount, turn their horses to the right-about and tie them together; then fire a shot, and the lion would at once come to the attack and spring upon the horses, and while in that position and engaged on the horses they would shoot him. I knew that I had five or six staunch Englishmen with me, so we dismounted and advanced about ten yards nearer, then, by dint of threat and harangue, having got the Dutchmen into line, the dogs being still rather in advance of us, but a little to the right, and barking at the spot where we knew the lion to be. At this moment I directed a youth near me to fire a shot into the long grass, where we could see the great monster's tail lashing the air, and hear her roaring like thunder. The young fellow did so, and it is well for us that the lion's first rage was vented on the dogs and not on us. As the shot struck over and passed into the ground far beyond, the lioness rushed like lightning, not upon us, but at the dogs, and with one in her mouth ran back at the same speed into her lair. I saw that the Dutchmen were right, and it was indeed ' gevaarlyk,' for had the lion come out at the same speed at us, some or one at least of us would bave been made mincemeat of. I never saw anything so quick. Her back was scarcely visible above the grass, her tail lashing the air, and really there was scarcely time to pull trigger before she was back again into her lair.

I looked round me and saw my English friends 
with nerves strained to the utmost, and I said in Dutch 'Be ready.' I then told another lad to fire into the high grass. This time there was no mistake. Almost with the report of the shot the lioness rushed to the front, and when at about twenty-five yards from us rose up into the air like a bird, and would have lit upon our very heads, had she not while in the air received several shots. A ball from my double rifle entered, and broke her shoulder-joint, and she fell short of us, but at our very feet; and in her agonies and struggles to get at us rolled over and over in the long grass, during which time she was dispatched by the barrels held in reserve. She was a glorious trophy of our sport, and the cheer that rose was only surpassed on that triumphant day when the monster elephant rolled in the dust at the 'Knysna,' a lasting glory and trophy to the cool bravery and nerve of His Royal Highness the Duke of Edinburgh. When the lioness first rushed on the dogs I can compare it to nothing (comparing great things to small) but to a cat in a room with a mouse; for if you have ever seen with what lightning speed she darts from one side to the other it will give you some idea of what took place on this occasion.

The lioness being killed, we had to send for a wagon to carry her to the camp, and it took twenty strong men to lift her into the wagon. Poor beast! I was sorry for her. She was of enormous size, and very 
fat, and before her blood was cold my two girls saw her deposited at their feet. We found a good breakfast prepared, and we enjoyed our repast on the banks of a beautiful stream of fresh water. Now comes the curious part of the story. The Zulu tribes at Natal are very superstitious, and believe that by eating the heart of a lion you become lion-hearted, or very brave; and the fat of a lion is supposed to possess all sorts of miracnlous virtues, such as the healing of the sick, \&c., \&c. Our servants made a perfect fortune in selling the heart, cut into diminutive bits, and the fat as medicine. You cannot conceive how fat the poor beast was; and she had two beautiful cat-like cubs inside her, which made me feel the more sorry for her death. Thousands of natives came to us for pieces of her flesh, like vultures in the desert, and there was not a vestige of the meat of the beautiful lioness left for the jackals who had so often helped her to her own prey.

I sent the skin of this lioness to His Royal Highness the Duke of Edinburgh when he went in the 'Helicon' to meet his bride in the Crimea. 


\section{CHAPTER XXIII.}

THE ELEPHANT-HUNT ; OR, ROYAL SPORT:

SOUTH AFRICA - 1867 .

Is August 1867, H.M.S. ' Galatea' arrived at the Cape of Good Hope, under the command of His Royal Highness the Duke of Edinburgh. Within a few hours of his arrival Sir Walter Currie and myself received a telegram at Graham's Town from the Secretary for the Cape Colony, informing us that the Duke wished to see us if possible before he proceeded en route to Australia, which he proposed doing in a very few days. We decided, therefore, to start at once for Cape Town, a distance of 700 miles, which we performed in three nights and four days.

This was hard work, as the only railway at the Cape did not lead in this direction, and the greater part of this road was an ordinary wagon-track. The conveyance which carried us was the common ' post-cart,' a vehicle on two wheels, and sometimes without springs, drawn by two or four horses, according to the stage. This cart travels as fast as horses can go, both night and day, without stopping for one moment, except to put in 
fresh horses, which are led out and 'put-to' when the post-cart arrives at the relay stations the approach being made known by blowing the post-horn. This post-horn also serves to clear the road, as all wagons and other obstructions are bound to get out of the road and make way for H.M. Royal Mail, or 'Post,' as it is there called. To perform the first part of this journey there is from Graham's Town to Port Elizabeth, the first 90 miles, a passenger-cart; and in order to gain a little time in advance of the 'Post,' Currie and I started in it; from Port Elizabeth we hired relay carts on to the Gamtoos River, where we arrived two bours ahead of the mail. Going down the Van Stardens River cutting, however, we had a narrow escape of our lives. We had changed our horses on the top of the hill, and had four wild, half-broken beasts in front of us. The road down this hill is in a cutting several miles long, on the face of almost perpendicular cliffs. A party of convicts were at this time repairing the road, and as we dashed down at the rate of about twelve miles an hour our leaders, on suddenly turning a corner, came upon this working party, with wheelbarrows and other lumber, in the road, when they suddenly swerved to the right. As a parapet .ran along the side of the road and there was no room to pass back between it and the cart, they went clean over it, and became suspended by the harness 
until they could be cut free; the leaders then went rolling down the precipice or declivity for some hundreds of feet. Luckily the parapet prevented the cart and wheel-horses frorn going over, and the latter were only bruised and cut against it. We never saw anything more of the leaders, and after a short delay passed on with the two horses only to the next relay stage.

The mail-cart arrived at the Gamtoos River about one o'clock in the morning. There were no other passengers, for we had secured the only two places beforehand. These carts are peculiar; the body is in the shape of a large box, into which the mails are packed till it is full, and the lid is then shut down; but there are many other large bags of letters and newspapers which cannot go inside; these are tied on the top of the cart. There is one tolerably fair seat next to the driver in front, but any other passenger must take his chance and either sit on the top of the bags or recline on them the best way he can. The night was pitch-dark and we were going along at a rattling pace towards Humans Dorp down an incline. I was sitting on the top of the bags, when all at once I felt the upper wheel of the cart strike a stone, and from the feeling and sound I knew that the cart was running on one wheel, and it must have continued so balanced for at least fifty yards; then over it went with a crash. I thought there was a flash of lightning, but on coming to I 
found it was my head that had first struck the ground as I was pitched from the top of the cart, and it must have been phosphoric light from my eyes that appeared to light up the surroundings. Currie, who had also a desperate 'pip' from the front seat, soon came to my assistance. Luckily the horses did not bolt; so after righting the cart and re-packing the mails with the aid of a wee bit of wax-candle which my friend had in his pocket, we again started. But we first walked back this fifty yards to see the small pebble. that had overturned us, owing to the rapid rate at which we were going; and from that spot to where the cart turned over there was only the trace of one wheel on the ground. My head was, as may be supposed, very sore all the way to Cape Town.

At Humans Dorp the relay horses were readyharnessed, and on we went to the Kroome, or Crooked River. After descending to the bed of this river the road keeps up it for many miles, having to cross the stream itself no less than fourteen times; and many of the fords were then so deep that the horses had to swim, and the cart was covered with water up to the bags; but the lower, or box part, is water-tight. The cart was several times nearly swept away by the rapid current.

Night again overtook us in Long Kloof; but here, except for the fords and deep rivers, the road was comparatively good. We passed on, and rattled down 
the Cradock Pass in the pitchdark of night at a fearful pace. This pass is one of the most extraordinary engineering works in the Colony. The road previously passed over the almost perpendicular mountain itself, but science and engineer skill have made the present road a gradual incline. The road is cut out of the very face of the mountain, and zigzags round the precipitous gullies in the most extraordinary manner, with thousands of feet of precipice below and overhanging mountains above. We must have gone down this incline at the rate of fourteen miles an hour, without being able to see the leading horses before us. At the foot of the mountain, on the 'George' side, there is a branch-road, which carries the mail into the town of that name, and returns to the main road at the same spot. We halted for the post-cart during this brief half-hour, and were able to take ' the forty winks' so much required. However, the 'post-horn' sounded, and we again got on our perches, and on rattled the two-wheeled vehicle, crossing the two Braak Rivers. About daylight we reached Mussel Bay in the early morn, and were enabled to snatch a hasty meal with an old friend, who also gave each of us a large piece of 'biltong;' which we 'whittled' at and fed on all the way to Cape Town. Now, biltong, or meat dried in the sun, retains all its nutriment, and is the most sustaining thing a man can eat. It might be made of great service in war-time, because the men 
could carry many davs' supply of it in a small compass without much additional weight.

But to return to our journey. In a few hours we reached the Gauritz River, which was flooded from bank to bank. The post-contractor, however, is bound to keep a mail-cart on each side; so after the mails and ourselves were conveyed over in a cranky boat we re-adjusted ourselves in the temporary cart (a thing without springs and cramped in size), and thus passed on to Riversdale and Swellendam. This latter town we reached at night; and without halting a moment drove on to Caledon, where we had a little adventure. The rule of passage by the mail-cart is, that those coming the longer distance have the preference of going on, to the exclusion of those who take their berths or passage from any given point on the road, or from one intermediate station to the other. It so happened that from Caledon to Cape Town there was a separate and rival contractor, and two of his friends had taken their passage to Cape Town in the mail-cart from Caledon; but we insisted on our right to go on, and it was about to become a question of some importance to us, as the two gentlemen had already mounted the cart and possessed themselves of the only two places. Near the starting-point there was a bridge, which it was necessary that the cart should pass over; and on looking round I saw my friend Currie on the bridge, revolver 
in hand, declaring that he would shoot one of the horses rather than let the cart pass over the bridge without us; and he was just the man to do what he said. At this moment the Dutchmen's pluck failed them, and the two passengers quietly dismounted and gave us the seats.

On, on, on we went as fast as horses could go ; and reached Cape Town that night, at about nine o'clock. We went direct to the comfortable old Civil Service Club, got rooms, and were indulging in hot baths before going to bed (after three nights and four days without rest), when we got a message from Mr. Southey to say that His Royal Highness wished to see us at once.

Our loyalty and love for the Prince, whom we had known in 1860, impelled us to obey orders without delay; so we dressed and went to a great ball given that evening to the Royal Prince at Cape Town. His Royal Highness expressed himself very pleased to see us, and it took Currie and myself back to the wonderful ' trek' we had with the Prince in 1860, when he was still a midshipman, and not then sixteen years old. This trek was through the interior of South Africa, leaving Her Majesty's Ship 'Euryalus' at Port Elizabeth, and rejoining her at Natal, His Royal Highness and party proceeding overland through Graham's Town, King William's Town, and Kaffraria, then inland, vîa Queen's Town, Burgher's Dorp, Aliwal North, over the Orange 
River, through Smithfield to Bloem Fontein (the capital of the Orange Free State), Wynberg and Harrismith; then through a portion of the Transvaal Republic, and across the great Tashlamber range of mountains into Natal Territory; through Colenso, Mooi River, Bushman's River, Howick, on the Telega, and to Pietermauritzberg, Natal. In those days the vast plains in the interior of Africa abounded in large game of every description, 600 of which fell in one day to the guns of the party. All this, however, I have recorded in another chapter.

His Royal Highness told us it was at first intended that he should remain but a few days at Cape Town, and His Excellency the Governor and the loyal and hospitable inhabitants of the Cape Colony, or rather the Cape Division-for all others were too far off-had made arrangements accordingly. Money was voted and subscribed, and entertainments crammed into a short space of time; in fact, our speed from the Frontier was merely on the chance of reaching Cape T'own to see His Royal Highness and pay our respects; but in the meantime things were changed; orders had been received from England to say that the Prince was to remain at the Cape of Good Hope for further instructions. This very much changed the order of things; the inhabitants had already expended the money voted and subscribed for entertainments and hospitality; and 
were all tired out with feasting and gaiety. It was equally trying to His Royal Highness, but above all he did not think it right that such lavish hospitality should be continued on his account for an indefinite time; so taking us into his own private room and telling us all this, His Royal Highness asked if we could propose anything to obviate the difficulty.

Currie and myself at once said that if he would place himself in our hands we would take him up country and show him some elephant-shooting. The Prince was delighted with the idea, and we returned to the ballroom to communicate the suggestion to his Excellency the Governor. Sir Philip, however, poohpoohed the idea, and offered to bet ten to one that we would not even see an elephant. I am not a betting man, but Currie took the Governor up at once, and the result of the bet will be seen by and by.

A second discussion in the private room settled the matter, and it was arranged that the expedition was to take place, and to start from Simon's Bay. About 400 or 500 miles up the coast to the eastward there is a magnificent forest, known as the Knysna, extending on to the Tzitsikama Forest. Currie and I knew there were large droves of elephants in this forest, and to that spot we proposed taking His Royal Highness. Two ships of war, the 'Racoon' and the 'Petrel,' were placed at the disposal of the Prince and the Governor, 


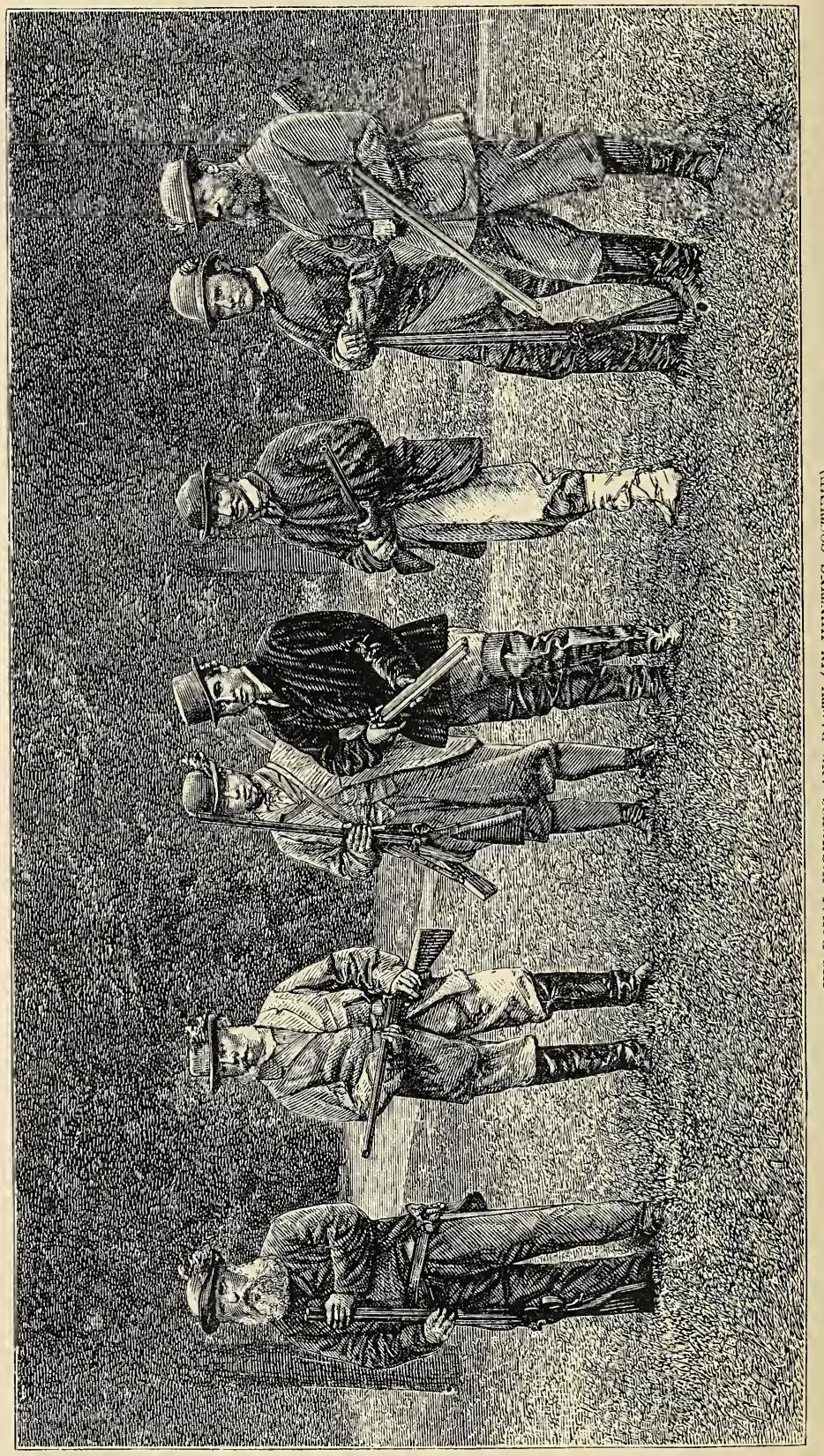


and a large party assembled on board the former at Simon's Bay. Currie and myself were invited as His Royal Highness's guests, and the Governor took a portion of his staff and some private friends with him.

The 'Petrel' was detailed to accompany the 'Racoon,' because her small size admitted of her crossing the bar and running into the little harbour inside the Knysna River mouth. We reached the offing of the Knysna on the afternoon of the second day; transhipped at sea from the 'Racoon' to the 'Petrel,' and entered the river, where numbers of people were collected, on the beautiful bluffs at the entrance, to welcome the Queen's son, the 'Racoon' lying off and on at sea outside.

His Royal Highness and the shooting-party landed and proceeded to a comfortable house, where we all dined and slept. At daylight next morning a large party of the gentry and farmers from the neighbourhood collected to welcome and accompany the Prince to the hunting-grounds. Saddle-horses were also provided for the whole party, and a couple of wagons carried tents and provender. Luckily a new road had

- just been completed through the immense forest, where the elephants were known to be. The cavalcade soon got under way, and the ride through this grand forest was magnificent. Here and there you came upon the fresh trace of the elephants; where they had just 
crossed the road into the dense wood of great trees towering sixty or a hundred feet above you. We passed on, however, inland to the outskirts of the forest, and pitched our camp on a beautiful spot, with ravines and clumps of large trees all round us, near the foot of the great range of mountains which runs parallel with the coast, dividing as it were the English from the Dutch inhabitants. At the camp we were met by many of the latter, who had passed over the mountain range from the Long Kloof District to pay their respects to the Prince.

At this first camp His Royal Highness's energy might be seen; he assisted in pitching the tents; and that done, he proceeded with his indiarubber tub to the running stream of water, carried back his own supply of fresh water, and then carried in large bundles of wood to the common camp-fire. The cook was set to work, and by dark we all sat down to a capital dinner.

A number of old elephant-hunters joined us at the Knysna, and Mr. Rex, who was born there, and knew the whole country, was with us, consulting with and directing the hunters. Several of these men were despatched over-night to 'spy out' the elephants, and we were to follow in the same direction at daylight in the morning. We got away from camp before sunrise, and after riding about six miles met two of the hunters coming down a hill to meet us. They reported that they 
had found seventeen elephants, in one herd or drove, feeding in a comparatively open space on the other side of the hill. As the hunters counselled great caution and silence, it was decided that only ten picked persons were to accompany His Royal Highness, whilst his Excellency the Grovernor and the remainder of the people remained perfectly quiet at the foot of the hill where they then were. The Prince, Currie, Rex, myself, and one or two others, and the hunters, then proceeded cautiously to the top of the hill, and certainly a glorious sight met our view. Looking down from this eminence you could see, as far as the eye could reach, a great aboriginal forest extending away for hundreds of miles in a belt east and west, and beyond it to the south the beautiful blue Indian Ocean. At, our very feet, sloping down southwards, on the face of the mountain from the top of which we had this magnificent view there was a small detached forest of gigantic trees; between the base of it and the edge of the great forest was some undulating ground, covered by scrub bush, great overgrown ferns, and long reeds and grass, in extent about a mile; and in the midst of this were these seventeen elephants, browsing upon the tender tops of all this succulent vegetation. From where we stood it seemed as if the elephants were in an 'open,' as the scrub appeared to come barely above their knees. All these elephants were large, and all 
elephants in South Africa, both male and female, have tusks. Amongst them we saw two large bulls which seemed to tower over the other elephants like castles in a fortress, and even at this distance the great extent of white tusks or ivory, extending many feet from the heads of these two monsters, was clearly visible.

His Royal Highness was very keen to go at once to the attack; but the hunters knew the ground, and that what appeared to us to be low scrub was a tangled mass of vegetation, through which it was almost impossible to move, except in the elephant-paths, and this we found to be the case when we subsequently had to go through it.

The experienced hunters in whose hands we had „placed ourselves consulted together for a long time; and as they were naturally nervous at the responsibility of taking the Queen's son into great danger they informed us that, in the position the elephants then were, it was impossible to get at them, and that we must wait for them to get into a more favourable one.

„There had been so much delay that the Governor's patience had failed him, and his Excellency and the large concourse of people had gradually crept up the hill and joined us. They were all equally impressed with the magnificent sight. As the elephants did not appear to take any notice of us, the hunters were actually talking of giving up the sport for the day, 
and waiting a more favourable opportunity of getting at them. When, however, His Royal Highness heard this he said, ' $\mathrm{Oh}$, no, a bird in the hand is worth two in the bush,' and referred to Currie and myself. $\mathrm{He}$ and I then decided to take the matter in hand, and it was arranged that half-a-dozen of us were to creep down through the forest, along the face of the hill, until we got opposite to where the elephants were, and near the edge of the forest, and there get into a position to shoot one as they came towards us. In order to make them come on two men were to be despatched on horseback along a ridge and so get beyond the elepharits before disturbing them; and as the wind was blowing from that direction the elephants would scent them, and naturally come towards us. We were to have twenty minutes' start, so as to be able to get into position before the horsemen started to alarm the elephants.

Currie and I had the responsibility of the Prince's life upon our hands, and we had agreed between ourselves before starting that we should propose to him to get into a monster tree. We found, however, as we got into the forest that all the trees had straight trunks, upwards of fifty or sixty feet high, without a branch of any sort, and that to climb any one was an impossibility. Besides this practical difficulty in the way of our design,. some of the hunters had dogs with them, which, to pre- 
vent their following us had been caught and tied up with thongs, and we had not got half-way to our position before the dogs had gnawed the thongs in two, and were following us down the forest, yelping and making a noise as dogs will do when following a trail.

The effect of the dogs' bark was most extraordinary. The elephants have a terrible dread of dogs; when, therefore, they heard the yelping the seventeen great monsters rushed together and formed a regular square, or rather circle, all their heads and tusks outwards, and so stood for some minutes in an attitude of defiance. It was the most striking thing imaginablelike infantry forming square to receive cavalry. Soon, however, the elephants, finding that nothing came to attack them, broke up and rushed direct for the forest where we were. Luckily we had got to very near the spot we intended, when the elephants came crashing into the forest not twenty yards from us, making large trees and underwood go down like straw before them. His Royal Highness, Currie, Rex, and myself had so far secured a good position that we were on high ground, with the dry bed of a stream or gully immediately before us, and also the sloping trunk of a great tree which had fallen. We had not much time for thought before the elephants were upon us; but two of the hunters . and His Royal Highness were the only ones who got shots at the monsters. The Prince fired two shots at 
one of the 'bulls' close to us, which made him and the rest turn and go back over the open in the direction of the great forest, the dogs which had joined us following them up, and barking, or speaking, as a fox-hunter would call it in England, like a pack of hounds.

The hunters were very much excited, exclaiming that the elephant was wounded, and that the dogs would never leave him. So off we started as fast as we could in pursuit, and it was after we had got out of the forest and into what we thought to be 'open' that we found our difficulty. This scrub and tangled vegetation was in most parts up to a man's neck, and unless in the elephant-tracks there was no getting through it at all. However, His Royal Highness had got into one of these tracks or paths, was outstripping us all, and would most likely have rushed right on to the elephants and been killed, had I not put my best leg foremost and ran on and caught him by the belt, until Currie and others came up.

It is well that we had foreseen the danger, for all at once as we approached the great forest there were all the elephants at the very edge of it, wheeled about and showing fight to the dogs. Towards the edge of the forest the scrub-bush got higher and higher, and when we had approached to within about eighty yards of the elephants one cow-elephant charged the dogs, which came running back on us, followed by the 
elephant to within a few yards of us. There was, however, so much brushwood, and it was just there so high, that the Prince could not get a good shot at her. All those around His Royal Highness were holding their shots for him to fire first, when a hot-headed Irishman who was standing far behind the Prince and at some distance above fired; and those who had reserved their shots, thinking that it was the Royal sportsman who had shot, no longer reserved their fire. In a moment a regular volley was poured into this elephant as she swerved away from us after the first shot. To me she seemed to disappear so suddenly that I thought she had fallen over in the underwood; such, however, was not the case. The sight we saw from this spot was one of the grandest I have ever looked on. The elephants on reaching the edge of the great forest had wheeled about and were charging the dogs one after the other. We could not approach them, as the brushwood grew gradually higher, and was very soon over our heads, and so thick and tangled that we could not force our way through it. Some of the elephants on our left front had young ones or calves by their side; and as the dogs attacked these mostly, they were being defended by several big elephants. To see these monsters charge, with their great ears thrown forward and trumpeting as if the last day had come, whilst great trees went down before them as if they were rotten 
sticks, was wonderful. But at the same time it was quite impossible to approach and shoot the monsters. By this time all the concourse of people had ridden down to the ridge above us, and were looking on. All at once one of the native hunters espied four large elephants standing by themselves on the face of a declivity on the further side of a ravine, or dry bed of a watercourse, which led down from the small forest, where the Prince had fired the first shot, to the great forest. These elephants appeared easy of access, and we all ran down, making our way through the low scrub as best we could to the ravine. By the time we got there the elephants had moved, and were no longer to be seen. The flat bottom or bed of this gully was overgrown by high acacias and other soft woods; the banks down to it were very steep, and it was supposed the elephants had taken cover in this bottom. A little higher up the ravine another gully entered it at nearly right angles from the other side, and it was while crossing this gully that the elephants became invisible. They were now on the bank opposite to us, but a little higher up, and His Royal Highness had to retrace his steps, rejoin us, and hurry along to get opposite to them. This was soon accomplished; and the Prince, standing upon a rotten stump of a tree, took deliberate aim and fired off the large elephant-gun which he carried into one of the elephants. The four elephants 
were walking quietly on the opposite bank, at about eighty yards' distance. The first shot was a shell, which was seen to strike the elephant just behind the shoulder, and smoke was actually seen to come out of the small hole from the exploded shell. The elephant fell on to his knees and trumpeted a fearful blast; this it repeated on the second shot, which also hit. A good many of the people had joined us by this time, and after the Prince's two shots at least forty other shots must have been fired at the elephants. Besides the four large ones there was a pretty calf at the side of its mother. No elephant was brought to the ground, but they struggled on into the small forest. I was very near being shot myself, for in the excitement of firing one young fellow from behind fired so close to my head that he blew my hat off, but did no further damage.

By this time it was getting late in the afternoon, and the dogs were so tired that when they were set on to follow the wounded elephant they would not budge an inch. We had also to get back to our horses on the top of the mountain, and then to ride some six or eight miles to the camp ; it was, therefore, decided that we should leave the wounded elephant until the next day.

The climb back through the scrub and up the face of the steep mountain was about the most fatiguing thing I have ever experienced. The Prince was as fresh as a kitten, but I confess I was done-the old 
wound had told against me; and had it not been that I caught hold of the tail of a horse which Mr. Barrington (who arrived by chance on the spot) offered to His Royal Highness, I do not think I should ever have got to the top of the mountain. Our horses were, however, waiting for us there, and we mounted and got back to camp some time after dark. A capital dinner was awaiting us, which we enjoyed all the more from having had no lunch; and after dinner we fought the battle over again while discussing the excellent cheer, and then adjourned to the camp-fire and smoked.

It was arranged that Currie and the hunters were to go back the next day and follow up the wounded elephant, and that His Royal Highness and the rest of the party should have a day at the smaller game. Unfortunately there was a great gale, and it poured with rain during the night and part of the next day; this did not, however, prevent Currie and the hunters from going to follow up the elephant, and they did not get back till late at night. They took up the 'spoor' or trace of the wounded elephants at the spot where we last saw them. It was easily traceable from the quantity of blood; and after getting into the forest near where the first shots were fired in the morning a great pool of blood was found where the monster had been leaning against a tree, as if to support itself. The wounded elephant continued to circle in this forest, winding 
across its own spoor so often that it became difficult to follow the last trace. He must have halted several times, as the hunters repeatedly came upon pools of blood; and although this has taken but a short time to tell Currie and the hunters followed his spoor from sunrise until dark without coming up to the monster; they found, however, repeated indications of being immediately upon him, and from the winding and zigzag trace the monarch of the forest must have been in a staggering condition, when darkness alone prevented them from coming up with the wounded animal.

Currie and the hunters did not reach the camp until late at night, and we were all much disappointed at the non-success of the day. His Royal Highness, however, expressed himself much pleased and gratified with the sport he had seen, and it was intended that we should return to the 'Knysna' the next day, reembark on board ship, and return to Cape Town.

The Prince has inherited the royal virtue of punctuality; and as it had been settled, before leaving Cape Town that we were to land on our return voyage short of Simon's Bay and attend a great 'battue hunt' of small game at Mr. Vanderbyl's farm, some distance from Cape Town, where great preparations had been made to receive and entertain the Royal Prince, it was decided that we were to give up further prospect of elephant sport, so as to arrive there at the appointed 
day. Fortune, however, favoured the brave in this case, as I believe she always does; and during the night an express arrived from the Port-Captain at the mouth of the Knysna, or Port Rex, to say that, owing to the severe gale the day before, the bar at the entrance of the harbour had 'got up' to such an extent that the 'Petrel' would not be able to cross it, or get out of the inner harbour, for some days. On the receipt of this news His Royal Highness said, 'Very well, gentlemen, the elements prevent me from keeping my engagement; it is not my fault that I cannot do so; I am now, therefore, prepared to continue the elephant-hunt.' We all rejoiced at this decision, and at once rousing up the native hunters, started them off in another direction to look up some elephants.

The Prince, his Excellency the Governor, and party followed at daybreak next morning, but not before we had partaken of a hasty breakfast, one dish being of 'scrambled eggs,' prepared by His Royal Highness himself. Servants were also sent on with baskets of provender for breakfast or lunch, as the case might be.

Our route lay through the same great forest which we had previously traversed, and we were making for the Downs to the eastward of the Knysna, where it was known that several 'rover' elephants had lately been seen. It was a long way through the great forest, but as we approached the outskirts, or broken and detached 
part of it near the sea, we met two of the hunters coming back to tell us that they had found a monster rover elephant in a detached part between the great forest and the Downs bush, on the coast. We therefore hurried on, passing several small farmhouses and bushrangers' huts and sawpits, where the elephants did great damage at night, until we approached the small forest, where the remaining hunters were watching that the elephant did not escape. This detached forest was on an elevated piece of land, about half a mile from the main forest, and about the same distance from the Downs bush, with a hollow between the small forest and the large one.

Ten persons, including Currie and myself, were again selected to accompany the Prince into the forest and 'stalk' the great elephant. Some of the hunters, with the dogs, were sent to the right to intercept between where the elephant was and the Downs bush, with a view of afterwards letting the dogs loose and driving the elephant towards us, in the event of our not being able to stalk him. The Governor and the large concourse of people on horseback were posted on the high ground to the left, near the great forest, looking down on the sport. Luckily the wind happened to be blowing favourably, that is, from the elephant towards us. We entered the forest at the west extremity and drew eastward; but once in the 
bush we found ourselves in a tangled mass of underwood, through which it was almost impossible to force ourselves; we did, however, manage to proceed some distance before we apprehended our danger. His Royal Highness was, as it were, in the care of Currie and myself, and we felt sure that directly the elephant was aware of our approach he would at once charge, and from the tangled nature of the underwood it would be quite impossible either to shoot him or to get out of the way. Whilst we halted to consult on this subject, we could actually hear the rumbling of the great beast's inside without being able to see him. We therefore decided to take the Prince back to the open and intercept the elephant whilst being driven from the small forest, where he was, to the big one, for which he was sure to make. After getting outside of the forest we mounted our horses and took up a position across the valley dividing the two forests, leaving the horses standing just below us. Notice was sent at the same time to the hunters on the other side to let loose the dogs and drive the elephant towards us. The moment the dogs got to the elephant the same strange scene occurred that we had observed on the first day's hunt: the elephant became violently enraged, charged the dogs in all directions, and you saw great forest-trees going down before his rushes. The monster would, however, on no account leave his retreat, but appeared 
to make a complete circuit of the forest, showing himself at one particular spot opposite to where we were posted each time he made the circuit. The first time he did so the elephant threw its great ears forward and appeared to look at us and decide not to come to the charge. The 'trumpeting' during all this time was something terrific.

His Excellency the Governor, who was on the high ground some distance above us, seeing the elephant appear at the same spot once or twice, galloped down to us, and said to me, 'Bisset, there is the elephant; why don't you go and shoot him?' This was all very well for his Excellency, but Currie and I had the responsibility of the Prince's life upon our shoulders, and we knew that if we went to the spot where the elephant appeared there would be considerable danger, as the ground sloped down from the forest, and to shoot an elephant whilst charging in that position is most difficult. I replied, therefore, that I was quite prepared to go and face the elephant if he would not come to us, and so was Currie, but that we did not like to take the Prince into such great danger. His Royal Highness, however, hearing what I said, at once exclaimed that he was himself ready to go and face the elephant.

We therefore walked to our horses, mounted, and rode up the slope to the edge of the bush, where the 


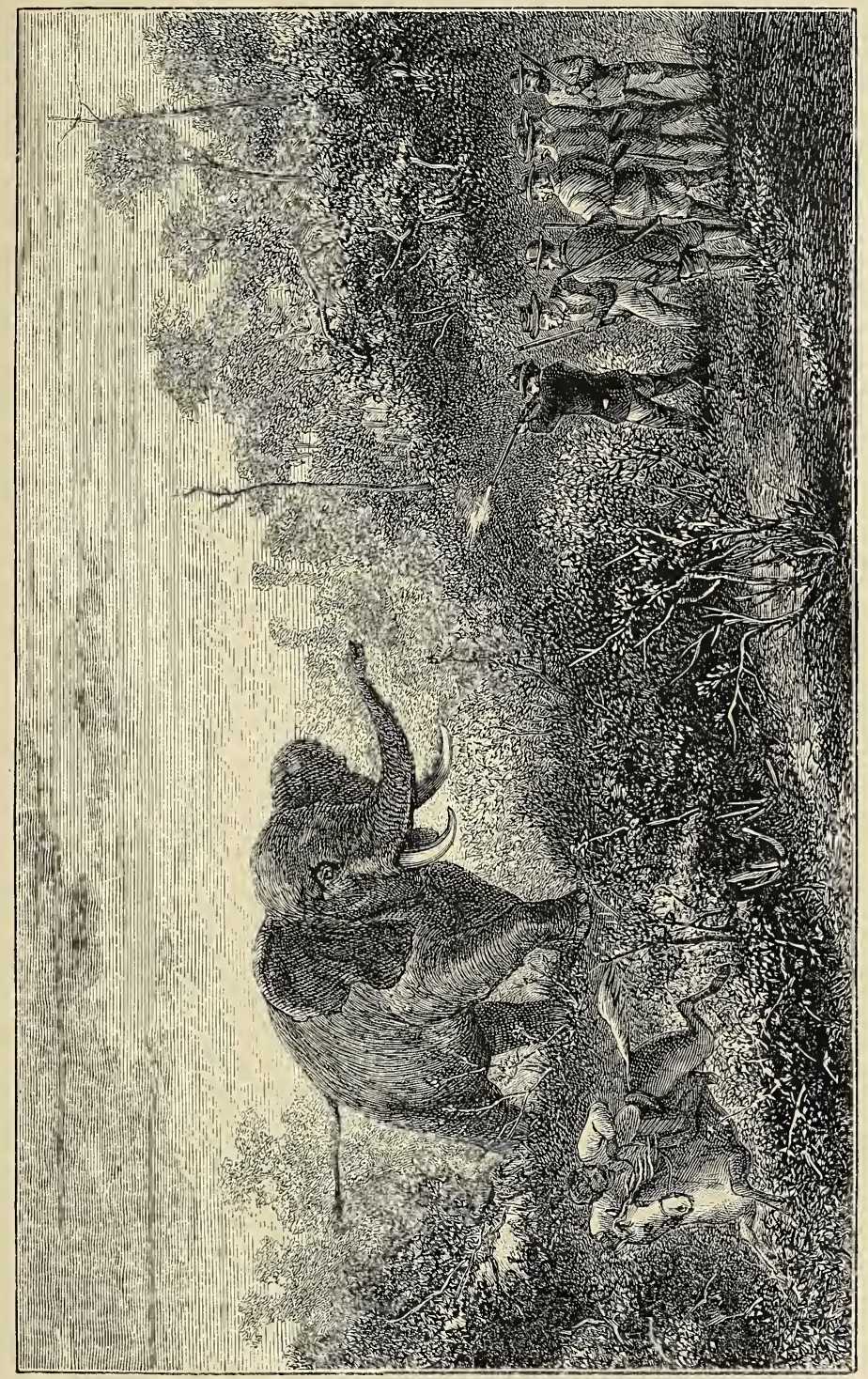



elephant had regularly appeared in making the circuit of the wood. We dismounted, and stood prepared; I was, however, quite aware that we were standing at a great disadvantage, because the elephant would charge down-hill at us, and it would be almost impossible to give him a deadly shot in that position, as an elephant's brain is not only very small, but is situated at the very back of his head. In a few minutes the elephant appeared at the same spot, but did not charge, passing on into the forest again. His Royal Highness did not see the beast to sufficient advantage to fire, and we all, therefore, reserved our shots. Immediately on our left front there was a little bare hollow, which led down from the forest, just where the elephant appeared; and knowing that he would be some time before he had again completed the circuit of the wood, I ran across this hollow, to see if I could find a better stand before he reappeared, and discovered that where $I$ then stood the ground almost commanded, or at any rate was on a level with the spot where the elephant came out of the forest. His Royal Highness and the rest of the party, therefore, ran across the hollow to where I was standing. The slope on which we now were continued eastward until it formed a 'brow', and it so happened that Currie told his after-rider to mount his horse and ride over this brow, to see that the elephant did not escape beyond it towards the great forest. On 
this brow, at a short distance from the forest where the elephant was, there was a small clump of trees, of soft wood, about the size of a large house, near which the Hottentot, in riding over the brow, in order to get as far from the forest as possible, had to pass.

In this clump of trees, with the instinct of his nature, was hid all the while a second rover elephant, which could not resist the temptation, but broke through the trees and charged out on the Hottentot, trumpeting enough to make the ground tremble. The after-rider had just time to wheel the horse about, lay in the 'sam-bok,' and race towards us. We were standing, ten of us in all, at about eighty yards from where the elephant broke cover, and the Hottentot was racing directly towards us, standing in his stirrups, looking over his shoulder in dreadful alarm, flogging his horse all the time, and shouting, 'Skeet, skeet, Aalamagtig. baas, skeet!' that is to say, 'Shoot, shoot, for God's sake, master, shoot!' The elephant kept overhauling the Hottentot at every stride, and was about to take him from the saddle with his trunk, the dark man looking ashy pale from fright, when all at once the furious beast saw the little knot of men standing not forty yards from him. At once his rage was diverted from the horseman to us; with his trunk thrown up and his great ears pushed forward, he rushed at us, trumpeting a blast that might almost awake the dead. 
It was an anxious moment, and each man appeared to hold his breath; the Prince stood perfectly calm and collected, and not a muscle moved in his face. We stood as it were in line; I was on the right of His Royal Highness, and Currie again on my right, with Gow, the Duke's man, immediately in his rear, with a spare gun.

We were all waiting on the Duke to bring down the elephant. He did not, however, pull trigger until the monster was within twenty yards of him, and then deliberately fired both barrels into his head. The first shot was a shell, which entered the head rather high up over the left eye, passed into the skull, and exploded inside, passing out upwards, and carrying away a large portion of the upper skull. The second ball entered the centre of the head, passed back into the honeycombed portion of it, and was cut out near the vertebræ. After the Prince had fired the rest of our party also fired at the monster. I was carrying Lord Newry's rifle, a single-barrelled gun, and my ball passed into the very centre of the head, and was cut out of the roots of the tongue. Currie, however, was the great man of the day after the Royal Prince. He did not so much as bring his great elephant-gun from the 'order' until all the others had fired-he was determined to do or die. It was his intention, whatever came, to save the Prince. His Royal Highness, however, has the palm, and 
deserves it too, of having saved not only his own life but those of the party also, for when the elephant got the two balls in the head he shut his eyes, shook his great head, and swerved to the left; and it was then that Currie raised his gun and put the ball (quarter of a pound weight) behind the ear, and the great monster fell to the ground, ploughing its great tusks some six feet into the earth. It is strange to say that not another ball had hit the elephant, although he was not twenty yards off and as big as a haystack. As the monster was still struggling His Royal Highness put a couple more balls into his carcass, and that shout arose which success alone can produce.

The Governor and party had been looking on, and the heart of more than one came into his throat when they saw the great beast charging down on the Prince in the open, and could not tell at the distance they were how the affair had terminated.

The position was certainly a most critical one. We were standing in heather up to our knees, so that it would have been impossible to get out of the way had the monster not been brought down. When the elephant was lying on its side the Prince had to stand upon a man's shoulders before he could get on to the carcass, where he opened his flask, and we all took a ' nip' to the success of the day.

The Hottentot after-rider was seen no more for the 


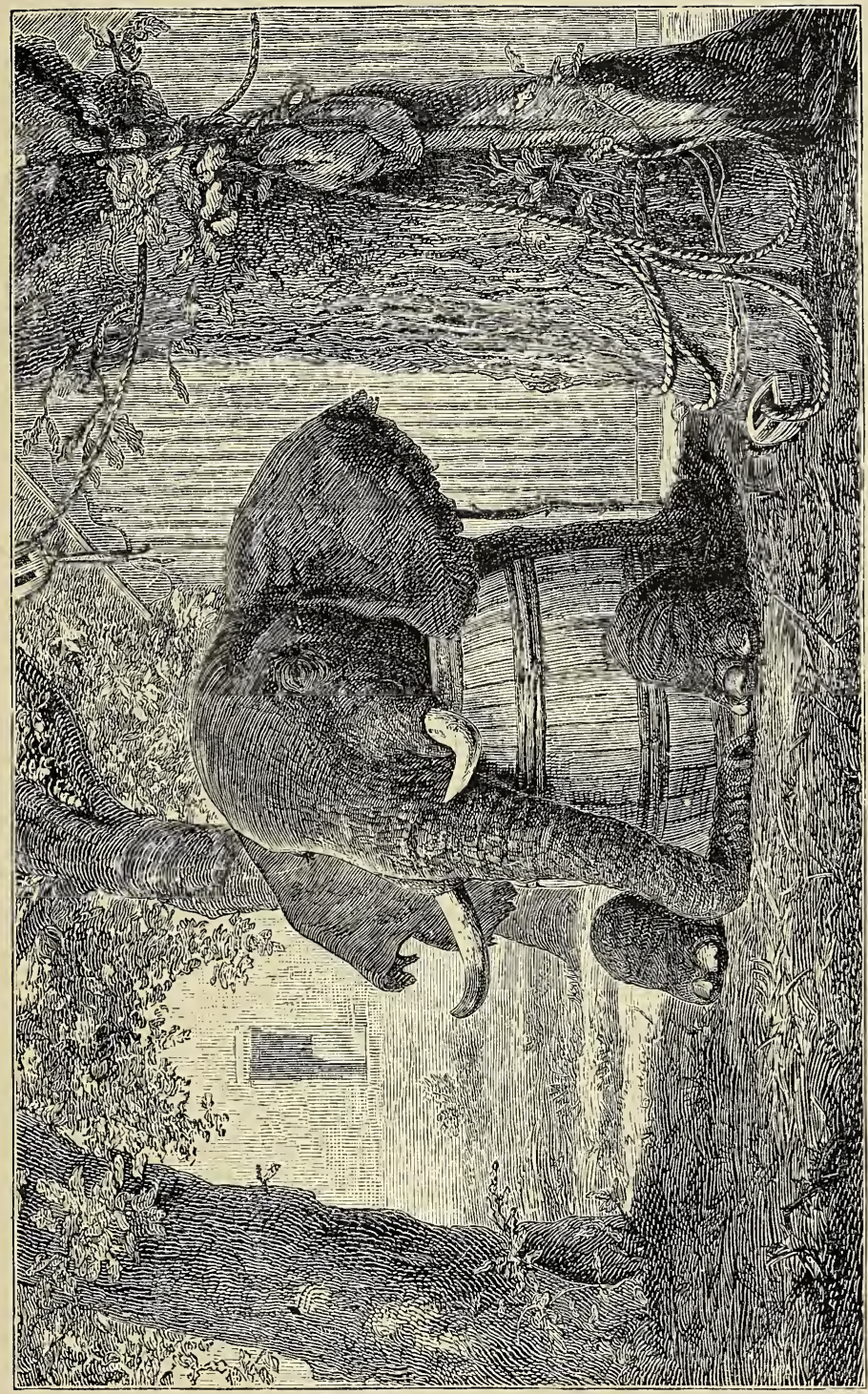



remainder of the day. When the elephant diverted his charge from him to us the 'Tottie' passed by like a rocket, went over the rise on the other side of the hollow, and never pulled rein until he reached the camp.

During all this time the hunters from the other side had been following up the first elephant, and had fired about twenty shots into him without bringing him down; and one of the hunters came across to us, saying, 'Now is the time for the Prince to shoot an elephant,' for they had got the first elephant so weary with the number of balls fired into him that the Duke might have gone up and shot him without danger. ' No,' said His Royal Highness, 'I have shot my elephant in the open, and anybody else that likes may go and shoot the other one.' A number of persons did go, and after firing about fifty more shots into the poor beast he was brought to the ground.

Before leaving the elephant shot by the Prince a question arose as to what was to be done with him. I suggested that he should be skinned whole, but the Governor laughed at the idea, and said it was quite impossible to skin so great a beast. It was not, however, the first elephant that I had skinned and taken the ivory from, so I called for volunteers from the farmers and people about, who soon produced their knives, and we set to work. The hunters were all delighted to see His Royal Highness throw off his jacket, turn up his 
sleeves, and set to work with them. Before five minutes were over he was up to his elbows in blood.

The difficulty was to get the carcass off the skin after it was cut loose ; besides, the huge head and feet were to be kept attached to the skin, and to pull the skin from under the great carcass a team of fourteen oxen had to be brought from the camp to drag it out; and it took more than twenty-five men to lift the head and skin into a truck-wagon to carry it to the camp.

We all then adjourned to the second killed elephant, which the Prince tried to photograph, on the dry system ; but the apparatus was out of order, or the chemicals not quite right, so the picture did not succeed. The second elephant was not quite so large as the one killed in the open, the dimensions of which were as follows: it stood thirteen feet high, was thirtytwo feet long from trunk to tail, and was twentyeight feet round the girth; the tusks were about six feet long, and the head and skin weighed over two tons.

It was a grand sight to see the two heads brought into camp, and when the 'Racoon' again steamed back into Simon's Bay, with one head at the fore and the other before the mainmast of the ship, thousands of people on shore cheered the Prince on his success and return from his first elephant-hunt in South Africa.

On crossing the bar at the mouth of the Knysna, 
the next day, the sea was still very rough, and the 'Petrel,' while in a trough between two great ' rollers,' bumped twice on the bar. I was at the time leaning over the side of the ship, and observed quantities of sand and gravel bubbling up in a turmoil of water as from a boiling caldron, and I shall never forget the coolness displayed by Captain Gordon on this occasion.

At the moment the ship bumped I was reflecting that not fifty yards from the very spot my uncle lost his ship, the 'Emu,' in 1817, whilst surveying the coast, previous to the British settlers of 1820 emigrating to the Cape Colony. The rock upon which she struck is still called by her name, the 'Emu Rock.'

A few days after this His Royal Highness gave a return ball at Simon's Bay to the inhabitants of Cape Town, and the most imposing ornament at the entrance of the ballroom was one of the elephants' skulls, which had been cleaned of all flesh and polished by the ship's company. The skeleton-head, with the great tusks protruding, was a fitting memorial of the hunt.

The carcass of the elephant shot on the first day's hunt was subsequently found by some roving hunters; the tusks were extracted from the head, and were sold to a Dutch farmer in the Long Kloof district-making in all three elephants killed by our hunting-party. 


\section{CHAPTER XXIV.}

SOUTH AFRICAN LEGEND : THE MANE-HAIR JACKAL.

What the pilot-fish is to the shark such is the jackal to the lion. In the great waters you rarely see the one without being attended by two of the pilots, darting about to warn off danger or to lead to prey. So also the jackal is invariably found in company with the monarch of the plains. This animal magnetism arises no doubt from mutual obligations, and the smaller creatures receive the crumbs which fall from the great one's table in return for their watchfulness and cunning. But my story, or native legend, is of a more spiritual species of the jackal, as named at the head of this article.

This jackal has very long hair, and a mane which extends from the neck all down the back, and it has brown stripes extending across the body.

The natives believe that the departed spirits of their relations and friends enter after death into this animal, and that it will always appear to warn them of danger or of some coming evil. Almost every Hot- 
tentot believes that there is a particular 'Tzhar,' as they call this species of hyæna, watching over his fortunes. They are rarely seen in the daytime, but hide in holes underground; they come out and prowl about in the dusk of evening and at night, and generally appear to their kindred spirits when sitting round a fire in the fields grilling the flesh of some sheep or kid purloined from the flocks during the day. Hence the communionship. 


\section{CHAPTER XXV.}

SOUTH AFRICAN LEGEND : THE ELEPHANT'S EYE.

Amongst other native legends at the Cape of Good Hope, the following is one connected with the elephant.

In a cavity in the head of the animal, between the eye and ear, you generally find a number of short pieces of stick or wood. These are invariably sought for by the native hunters when cutting out the ivory, and are believed by them to possess all sorts of miraculous virtues. They believe that the elephant will never molest or hurt you while in possession of one of them, and that no wild animal will come near or attack you while protected by its influence.

When benighted in the forest the least smoke created by burning one of these pieces of wood will keep every description of wild beast from molesting you.

It is quite true that most elephants have these pieces of wood in this cavity near the eye, but they are no doubt accumulated from the great monster continually charging through the forest, and what would 
be a small speck of dirt in the eye of man is in that of the elephant a tolerably-sized piece of wood, which naturally works itself into the cavity made apparently by nature to receive it; while smoke from any other wood would have about the same effect upon all wild animals.

I can well understand how these pieces of wood came first to be discovered by the hunters, because near the same spot where they collect is situated also the 'titbit,' or delicate morsel (for eating purposes), of the elephant; it consists of a portion of fat and lean, which is between the eye and the hollow alluded to; and moreover to cut the ivory tusks from the head you have to cleave this very part.

The flesh of the elephant is very coarse-grained, and peculiar in flavour, but the natives are nevertheless fond of it. Next to that peculiar portion near the eye, the foot is considered very good eating, and the hunters cook it as follows : a very large fire is made, and when well burned down to ashes and embers a hole is made in the centre, and the foot, with the skin on it, placed therein, the ashes and embers raked over it, and another large fire made on the top. Next morning before proceeding to 'sport' an apparently large black cinder is discovered, poked out of the fire and beaten with a good-sized pole; the outside black of the skin flies off, and the foot is served up. With a sharp 
knife you cut round and peel off a couple of inches of the skin at a time, and inside of it find a sort of brawn which is not bad eating. The elephant's foot consists of a number of small bones embedded in gristle, meat, and fat; so that the whole, when you have poked out the bones, cuts into slices something like brawn; and with the appetite engendered by fresh air and hard work does not require any other sauce. The foot of the sea-cow or hippopotamus done in this way is about the best thing in the world. 


\section{CHAPTER XXVI.}

CONTINUATION OF SOUTH AFRICAN LEGENDS: THE WOODPECKER'S NEST.

IT is well known that the woodpecker builds its nest in hollow trees; and the 'woodpecker taps the hollow beech tree' not only to seek its food hut to get into the hollow of the tree to build its nest. The hole is cut into the tree so round and regular that it appears as if done by machinery.

The 'tat-tat' which you hear wherever the bird is, is mostly to disturb insects, upon which she feeds, but it is often while boring a hole with its bill through the outside portion of a hollow tree to get into the cavity inside; and in order to make a foundation there, on which to build its nest, and to prevent the eggs from falling down the hollow, the bird cuts down and carries into the tree a great number of short pieces of stick; these are placed across each other in the most intricate and ingenious manner; and the natives believe there is a great charm in some of them. Their mode of discovering the charmed sticks is as follows : 
When a tree has been found in which the woodpecker has built a nest (which is discovered by the round hole bored or cut into it), the tree is felled to the ground and cut open; all the short pieces of stick forming the foundation of the nest are collected and taken to the nearest stream of running water and thrown into the river. Most of the pieces will be washed down by the current, but some two or three or may be more of them will go up-stream, thereby indicating, as the natives believe, their miraculous character. These charmed pieces are secured and cut into lengths about an inch long, strung like beads, and worn round the neck or about the person, and are supposed to be an antidote against all illness or evil. The natives will burn the end of the stick and inhale the smoke for headache, or scrape it and take it internally for all sorts of qualms or ailments; and moreover they believe these sticks counteract the power of their being hewitched.

Poor, ignorant savages, how a little 'knowledge would enlighten their minds! Yet how different is practice from theory! I well remember once out of many times being on the wrong side of a flooded river, and wishing to communicate with the other side. The current was so strong that no one would at first venture to plunge in and attempt to swim over. My chief, who was present, being a theoretical soldier, at once cut a 
piece of light wood into a particular shape, and applying a piece of string (loose) from end to end, and another one attached to it, at a particular angle, on the principle of that for flying a kite, endeavoured to pass a line over the river.

It was very interesting to see the improvised boat battle against the stream; but it did not succeed, in consequence of the pressure from the current on the line behind the pilot-shaped float. This must be the principle that enables some of the many pieces of wood cut by the woodpecker to go up-stream, and the imagination, as in homœopathy, must do the remainder.

In our case some of us had to strip and plunge boldly into the river; and although carried down for a considerable distance, reached the other side of the flooded water. On another occasion we fired a stick out of the barrel of a gun with a piece of string attached to it, the line being so coiled that it could easily run out, and in that way communicated with the other side. But there is nothing like a good swimmer, if he has confidence in himself. 


\section{CHAPTER XXVII.}

\section{A DAY AMONGST THE GNUS.}

$\mathrm{ON}_{\mathrm{N}}$ one of my early hunting expeditions into the interior of South Africa, while the game was still plentiful both within and beyond the borders of the Cape Colony, I remember having what I shall call a very fair day's sport among the gnus, or African bison.

They are a peculiar animal-something between the ox and the antelope-and are generally found in great herds; but old 'bulls' are often turned out from the herds by younger aspirants, and 'dot' over the plains by themselves, like 'rover' elephants. They are in appearance the most grotesque of all African game, for though not of large size they look almost as big as buffaloes. This arises partly from their peculiar shape. They have comparatively very small hind quarters, while they are high in the shoulder and deep in the chest; added to this, they have a very deep dewlap and a bristly mane, which stands upright, and adds much to their apparent size.

It is said by the natives of South Africa that the 
gnu is a ' $\mathrm{mad}$ ' animal, and the manner in which they rush about, whether singly or in herds, would certainly impress you with this idea.

They carry their heads very high, have buffaloshaped horns, with the points turning up; their eyes look like balls of glass, and they have a flowing tail, with long white or brindled hair, something between that of a horse and a cow. With these they lash themselves perpetually, whirling and rushing about in all directions, from and towards you, bringing their heads down to the charge or high up in the air, and at the same time kicking up with their heels like a horse.

Whole herds do the same thing-so much so that at first you are half-afraid they are going to charge you, when suddenly they turn and go off in the other direction.

They very rarely do charge unless when wounded, and then if one of the herd takes a 'lead ' the remainder will generally follow. Now is the time to 'race' for the head of the herd; and the remainder will then pass close to you and give you a fair chance of knocking over a couple right and left, even with the old muzzle-loading double guns. At the present day, with a breech-loader or a repeating rifle, you might kill several before a good-sized herd passed you.

The day's sport I am about to relate took place while I was passing up the banks of the Orange 
River, between Colesberg and Buffels Vley, as it was then called, and situated just beyond the border of the Colony, but since then annexed to it; and a goodsized town has sprung up there, named Aliwal North, after my old friend and commanding officer, Sir Harry Smith.

The evening previous to the 'day's sport' I had reached the homestead of a South African pastoral farmer-one of those who in that day roamed about the unoccupied country with their flocks and herds, and almost lived upon the flesh of game. 'Mine host' on this occasion was not a Dutchman, but an ex-missionary, who had taken to a pastoral life as more congenial to his habits. Yet, from having practised as a 'curer of souls,' he now undertook to cure bodily ailments in addition to his farming operations, finding the one, in a worldly sense, more profitable than the other. His flocks and herds were considerable, and his cures were said to be miraculous; his hospitality was certainly unbounded. He was also blessed with a large family.

In those days these migratory farmers did not build houses, but lived in their wagons, or erected what is called a 'hartebeast' hut, made by a series of rafters sloping from the ground to where they meet above, with cross-lathing and covered with long reeds or bulrushes, and plastered on one or both sides. There is usually only one door, but the hut may be divided 
into any number of rooms, according to its length. For the sake of light and air a small window is generally made in each room.

Mine host had erected one of these huts, and unfortunately I was told off to occupy the far-end room. Hence I had to pass through his own bedroom and the one occupied by his grown-up daughters; thus there was no escape for me after once going to bed. I had been sleeping in the open 'veldt' for some days previously, and my present bed looked so luxurious in comparison that I was not long before putting the light out, intending to enjoy a good sleep. But alas! how vain is man's desire! Before I could steep the senses in forgetfulness I began to feel myriads of creeping things crawling over me-not light infantry, but heavy monsters. It was something terrible. 'Lucifer-matches' were not invented in those days, and the light being out, I had no alternative but to get out of bed and try to sleep on the floor, with my cloak around me. That situation was, however, worse than the other. I next tried to get out of the window, but after getting my head and part of my body through I 'stuck fast,' and with some difficulty got back into the hut, and had to remain in torture until daylight, when I was enabled to pass through the young ladies' room out of the house.

My horse had been well cared for ; and after partaking of a cup of coffee, with some 'biltong' and biscuit, 
one of the sons and myself started for the day's shooting amongst the 'wildebeasts,' which were in thousands on the plains around us.

My gun was a double-barrelled smooth-bore, carrying eight balls to the pound; and I had two pouches with no less than 110 balls round my body (eleven pounds weight of lead, besides powder, \&c.). It was my first regular day's sport after gnus, and I fired over fifty shots before bringing down a single wildebeast. This was partly owing to the exaggerated appearance of the animal. After this I began to calculate his size better, the speed he was going, and the distance from me, and before eleven o'clock in the day I had got rid of the remaining sixty bullets, but not without counting my eleven head of dead gnus, which was considered a fair day's sport. My young friend had also killed his nine head, and the father had to send an ox-wagon to carry the game home, in order to cut up the flesh and make his winter supply of dried meat.

Dreading my companions of the night before, I decided to go on in the afternoon and sleep in the 'veldt,' and the next day, with my after-rider and packhorse, reached Buffels Vley, where I was most hospitably received by Mrs. de Wet.

This Vley deserves a few words of notice. Formerly it was a marsh, covered with long reeds and rushes, the vegetation being so long and rank that 
buffaloes used to hide therein. A hunter, in trying to force his horse over it, broke a hole through the crust of peat-earth, and the man narrowly escaped falling into a lake of hot water. From this time forth the vegetation began to wither, and at the present time the whole extent of the former marsh is quite bare of grass and dried up.

The small hole originally broken through has gradually become of large extent, and exposes a great lake of hot water, with a crust of about eight feet of earth above it. The expanse of water appears to extend to a considerable distance underneath.

The water itself is very hot-nearly up to boiling: heat-and has a peculiar taste and smell-something like what would be the washings of a gunbarrel. The farmers in the neighbourhood have cut an aqueduct down to the level of the water, and leada 'flow' from it for some miles to irrigate their cornfields. The water becomes cool before running very far along the watercourse and is then found to be very fertilising to the growing crops.

This extraordinary hot-spring or underground lake is not far from the Orange River, but its level must be some hundreds of feet above the bed of the river. It is now a part of the Cape Colony, and the water is conducted into the town of Aliwal North, which is a fastrising place, and destined in the future to be a great 
centre of commerce in South Africa. The water becomes perfectly pure before reaching the town, and is said to be very wholesome, possessing mineral qualities of a high order.

When I first visited the spot, in 1837, Mrs. de Wet, the widow of a Dutch farmer, and her family were the nearest residents to the Vley and had a certain ownership of the property. There was even then a small settlement of traders on the left bank of the Orange River; among' whom I well remember the 'Jansens,' Thomas Dry, and Glasher.

Before crossing the Orange River, I joined two friends (Percy Crause and Mr. Saunders), and we organised an expedition far into the interior of Africa, where we had great sport, shooting nearly every description of African antelope and wild animal. 


$$
\left[\begin{array}{c}
\cdots \\
0
\end{array}\right]
$$





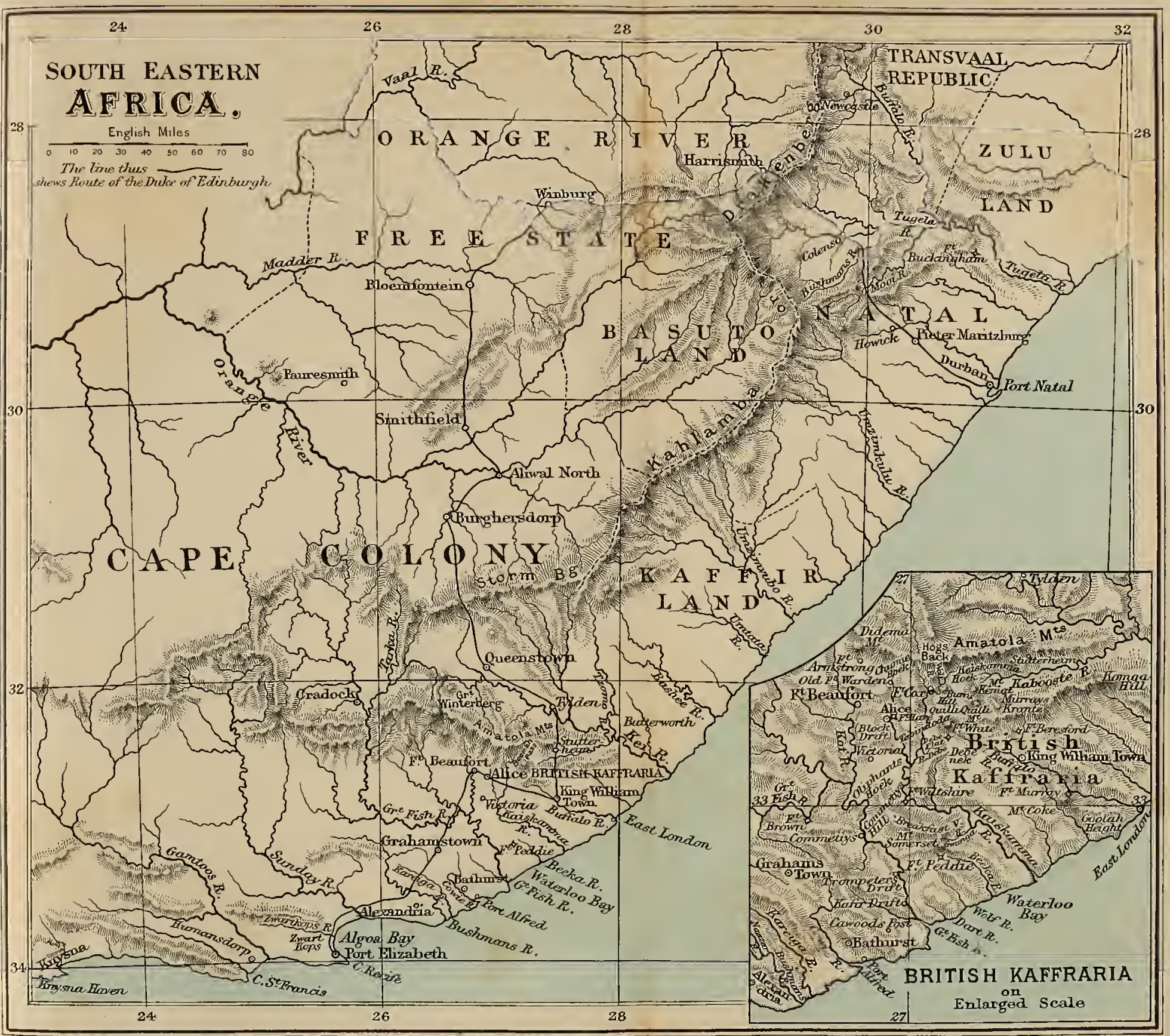

London; J.Murray, Albemante Str.t 


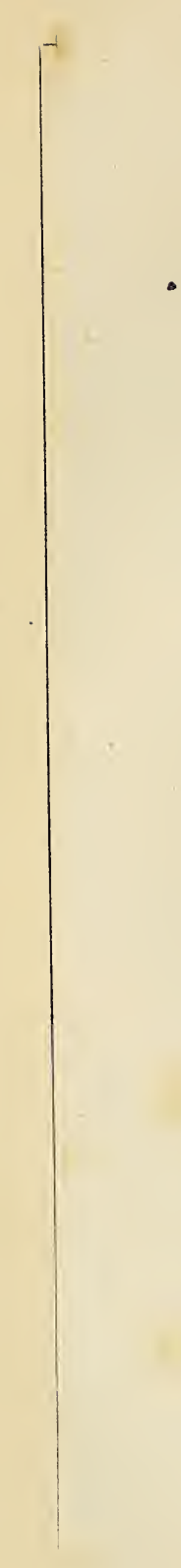




\section{MR. MURRAY'S}

\section{GENERAL LIST OF WORKS.}

ALBERT (The) MEMORIAL. A Descriptive and Illustrated Account of the National Monument erected to the PRINCE CONSORT at Kensington. Illustrated by Engravings of its Architecture, Decorations, Sculptıred Groups, Statues, Mosaics, Metalwork, \&c. With Descriptive Text. By Doyne C. Bell. With 24 Plates. Folio. 12l.12s. (PnINCE) SPEECHES AND ADIDRESSES with an Introduction, giving some outline of his Character. With Portrait. 8vo. 10s. $6 d$.; or Popular Edition, fcap. 8vo. 1 s.

ABBOTT'S (Rev. J.) Memoirs of a Church of England Missionary in the North American Colonies. Post 8vo. 2s.

ABERCROMBIE'S (JoHN) Inquiries concerning the Intellectual Powers and the Investigation of Truth. 19th Edition. Fcap. 8vo. 3s. $6 d$. Edition. Fcap. 8vo. 2s.6d.

ACLAND'S (Rev. Charles) Popular Account of the Manners and Customs of India. Post 8vo. 2s.

ESSOP'S FABLES, A New Version. With Historical Preface. By Rev. Thomas James. With 100 Woodcuts, by Tenniel and Wolf. 64th Thousand. Post 8vo. 2s.6d.

AGRICULTURAL (ROYAL) JOURNAL. (Published half yearly.)

AIDS TO FAITH : a Series of Theological Essays. 8vo. $9 s$.

\begin{tabular}{|c|c|}
\hline $\begin{array}{l}\text { Niracles of Christianity } \\
\text { Evidences of } \\
\text { Prophecy \& Blosic Record of Creation } \\
\text { Ideology and Subscription } \\
\text { The Pentateuch } \\
\text { Inspiration } \\
\text { Death of Christ } \\
\text { Scripture and its Interpretation . }\end{array}$ & $\begin{array}{l}\text { DeAN MANSEL. } \\
\text { BISHOP F ITZGERALD. } \\
\text { Dr. MCCAUL. } \\
\text { Canon CoOK. } \\
\text { Canon RAWLINSON. } \\
\text { BISHOP HAROLD BrowNE. } \\
\text { ARCHBISHOP THOMSON. } \\
\text { BISHOP ELLICOTT. }\end{array}$ \\
\hline
\end{tabular}

AMBER-WITCH (Tнв). A most interesting Trial for Witchcraft. Translated by LADX DUFF Gordon. Post 8vo. 2s.

ARMY LIST (The). Published Monthly by Authority.

ARTHUR'S (Litrue) History of England. By LAdY Carlootr. New and Cheaper Edition, continued to 1872. With 36 Woodcuts. Fcap. 8vo. 1s.6d.

AUSTIN'S (John) Lectures on Generat JuRISpRUdence; or, the Philosophy of Positive Law. 5th Edition. Edited by RoBert CAMP. BELL. 2 Vols. 8vo. $32 s$.

Student's Edition, compiled from the above work. By Robert Campbell. Post 8vo.

ARNOLD'S (Thos.) Ecclesiastical and Secular Architecture of Scotland : The Abbeys, Churches, Castles, and Mansions. With Illustrations. Medium 8vo.

[In Preparation. 
A DMIRALTY PUBLICATIONS; Issued by direction of the Lords Commissioners of the Admiralty:-

A MANUAL, OF SCIENTIFIC ENQUIRY, for the Use of Travellers. Edited by Sir John F. Herschel and Robert Main, M.A. Fourth Edition. Woodeuts. Post 8vo. 3s.6d.

GREENWICH ASTRONOMICAL OBSERVATIONS 1841 to 1846, and 1847 to 1871 . Royal 4 to. 20s. each.

MAGNETICAL AND METEOROLOGICAL OBSERVATIONS. 1840 to 1847 . Royal 4 to. 20 s, each.

APPENDICES TO OBSERVATIONS.

1837. Logarithms of Sines and Cosines in Time. $3 s$.

1842. Catalogue of 1439 Stars, from Observations made in 1836 to 1841. $4 s$.

1845. Longitude of Valentia (Chronometrical). $3 s$.

1847. Description of Altazimuth. $3 s$.

'Twelve Years' Catalogue of Stars, from Observations made in 1836 to 1847 . $4 s$.

Description of Photographic Apparatus. $2 s$.

1851. Maskelyne's Ledger of Stars. $3 s$.

1852. I. Description of the Transit Circle. $3 s$.

1853. Refraction Tables. $3 s$.

1854. Description of the Zenith Tube. $3 s$.

Six Years' Catalogue of Stars, from Observations. $184 \mathrm{~S}$ to 1853. $4 s$.

1862. Seven Years' Catalogue of Stars, from Observations. 1854 to 1860. $10 s$.

Plan of Ground Buildings. $3 s$.

Longitude of Valentia (Galvanic). $2 s$.

1864. Moon's Semid, from Occultations. $2 s$.

Planetary Observations, 1831 to 1835 . $2 s$.

1868. Corrections of Elements of Jupiter and Saturn. $2 s$.

Second Seven Years' Catalogue of 2760 Stars for 1861 to 1867. 4s.

Description of the Great Equatorial. 3s.

1856. Descriptive Chronngraph. 3s.

1860. Reduction of Deep Thermometer Observations. $2 s$.

1871. History and Description of Water Telescope. $3 s$.

Cape of Good Hope Observations (Star Ledgers). 1856 to 1863. $2 s$. 1856. 5s.

Astronomical Results. 1857 to 1858 . 5s.

Report on Teneriffe Astronomical Experiment. 1856. 5s.

Paramatta Catalogue of 7385 Stars. 1822 to 1826 . $4 s$.

ASTRONOMICAL RESULTS. 1847 to 1871. 4to. $3 s$. each.

MAGNETICAL AND METEOROLOGICAL RESULTS. 1847 to 1871. 4to. 3s. each.

REDUCTION OF THE OBSERVATIONS OF PLANETS. 1750 to 1830. Royal 4to. 20s. each.

to 1830.2 Vols. Royal 4to. 20 s. each.

LUNAR OBSERVATIONS. 1750 1831 to 1851 . 4to. 10 s. each.

BERNOULLI'S SEXCENTENARY TABLE. 1779. 4to. $5 s$.

BESSEL'S AUXILTARY TABLES FOR HIS METHOD OF CLEAR-

ING LUNAR DISTANCES. 8vo. $2 s$.

ENCKE'S BERLINER JAHRBUCH, for 1830. Berlin, 1828. 8vo. $9 s$. HANSEN'S TABLES DE LA LUNE. 4to. 20s.

LAX'S TABLES FOR FINDING THE LATITUDE AND LONGITUDE. 1821. 8vo. 10 s. 
Admiralty Publications-continued.

LUNAR OBSERVATIONS at GREENWICH. 1783 to 1819. Compared with the Tables, 1821. 4to. 7s.6d.

MACLEAR ON LACAILLE'S ARC OF MERIDIAN. 2 Vols. 20s.each.

MAYER'S DISTANCES of the MOON'S CENTRE from the PLANETS. $1822,3 s$.; 1823, 4s. 6d. 1824 to 1835 . 8vo. $4 s$, each.

TABUL ASTRONOMICAL OBSERVATIONS MADE AT GOTTINGEN, from 1756 to 1761 . 1826. Folio. 7s. $6 d$.

NAUTICAL ALMANACS, from 1767 to 1877. 2s. $6 d$. each.

SELECTIONS FROM, up to 1812. 8vo. $5 s$.

1834-54. $5 s$. SUPPLEMENTS, 1828 to 1833, 1837 and 1838.

2s. each. TABLE requisite to be used with the N.A. 1781. 8vo. $5 s$.

SABINE'S PENDULUM EXPERIMENTS to Detranine THE FIGURe OF THE Earth. 1825. 4to. $40 s$.

SHEPHERD'S TABLES for CoRrecting Lunar Distances. 1772. Royal 4to. $21 s$.

TABLES, GENERAL, of the MOON'S DISTANCE from the SUN, and 10 STARS. 1787. Folio. 5s.6d.

TAYLOR'S SEXAGESIMAL TARLE. 1780. 4to. 15s.

TABLES OF LOGARITHMS. 4to. $6 \mathrm{c} s$.

TIARK'S ASTRONOMICAL OBSERVATIONS for the LONGITUDE of MADEIRA. 1822. 4to. $5 s$.

- CHRONOMETRICAL OBSERVATIONS for DIFFEFENCES of Longitude between Dover, Portsmouth, and Falmouth. 1823. 4 to. $5 s$.

VENUS and JUPITER: ORSERVATIONS of, compared with the TABLES. London, 1822. 4to. $2 s$.

WALES' AND BAYLX'S ASTRONOMICAL OBSERVATIONS. 1777. 4to. $21 s$.

- REDUCTION OF ASTRONOMICAL OBSERVATIONS MADE IN THE SUUTHerN HeMisphere. 1764-1771. 1788. 4to. $10 s .6 d$.

BARBAULD'S (Mrs.) Hymns in Prose for Children. With 112 Illustrations. Crown 8vo. 5s.

BARROW'S (Sir JoHN) Autobiographical Memoir, from Early Life to Advanced Age. Portrait. 8vo. 16s.

(JонN) Life, Exploits, and Voyages of Sir Francis Drake. Post 8vo. 2s.

BARRY'S (Sir Charles) Life and Works. By Canon Barry. Second Edition. With Portrait and Illustrations. Medium 8vo. 15:

BATES' (H. W.) Records of a Naturalist on the River Amazon during eleven years of Adventure and Travel. Third Edition. Illustrations. Post 8vo. $7 s$. 6 d.

BEAUChERK'S (Ladi Diana) Summer and Winter in Norway. Third Edition. With Illustrations. Small 8vo. $6 s$.

BELCHER's (LADY) Account of the Mutineers of the 'Bounty,' and their Descendants; with thir Setrlements in Pitcairn and Norfolk Islands. With Illustrations. Post 8vo. 12s.

BELL'S (Sir Chas.) Familiar Letters. Portrait. Post 8vo. $12 s$. 
BELT'S (Thos.) Naturalist in Nicaragua, including a Residence at the Gold Mines of Chontales ; with Journeys in the Savannahs and Forests; and Observations on Animals and Plants. Illustrations. Post 8vo, 12s.

BERTRAM'S (JAS. G.) Harvest of the Sea : an Account of British Food Fishes, including sketches of Fisheries and Fisher Folk. Third Edition. With 50 Illustrations. 8 vo. $9 s$.

BIBLE COMMENTARY. Explanatory and Critical. With a Revision of the Translation. Py BISHOPS and CLERGY of the ANGLICAN CHURCH. Edited by F.C. Cook, M.A., Canon of Exeter. Medium 8vo. Vou. I., 30s. Vols. II. and III., 36s. VoL. IV., $24 s$. Genesis ............ Bishop of Ely.

Exodus ............. Canon Cook; Rev. Sam. Clark.

Vol. I. Leviticus ........... Rev. Samuel Clark.

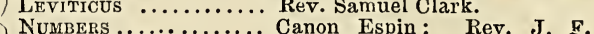
DeUteronomy

Joshu $\ldots \ldots \ldots \ldots \ldots, \ldots)$ Canon Espin.

Vols. II. and III. Judges, RUTH, SAMUEL. Bishop of Bath and Wells.

Kings, Chronicles, Ez-
ra, Nehemiah, Esther Canon Rawlinson.

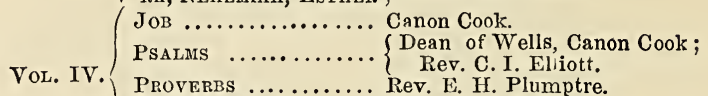

Ecclesiastes ........ Rev. W. T. Bullock.

SONG OF SOLOMON .... Rev. T. Kingsbury.

Vol. V. $\left\{\begin{array}{l}\text { Isaiah............... Rev. W. Kay, D.D. } \\ \text { Jeremiah ........ Dean of Canterbury. }\end{array}\right.$

BICKMORE'S (A. S.) Travels in the Eastern Archipelago, 1865-6; a Popular Description of the Islands, with their Natural History, Geography, Manners and Customs of the People, \&c. With Maps and Illustrations. $8 \mathrm{vo}$. $21 s$.

BIRCH'S (SAMUEL) History of Ancient Pottery and Porcelain : Egyptian, Assyrian, Greek, Roman, and Etruscan. Second Edition. With Coloured Plates and 200 Illustrations. Medium 8vo. $42 s$.

BIRD'S (Isabelia) Hawaiian Archipelago; or Six Months Among the Palm Groves, Coral Reefs, and Volcanoes of the Sandwich Islands. With Illustrations. Crown 8 vo.

BISSET'S (ANDREw) History of the Commonwealth of England, from the Death of Charles I. to the Expulsion of the Long Parliament by Cromwell. Chiefly from the MSS. in the State Paper Office. 2 vols. 8 vo. $30 s$.

BLUNT'S (Rev. J. J.) Undesigned Coincidences in the Writings of the Old and New Testament, an Argument of their Veracity : containing the Books of Moses, Historical and Prophetical Scriptures, and the Gospels and Acts. Eleventh Edition. Post 8vo. 6s.

History of the Church in the First Three Centuries. Fifth Edition. Post 8vo. $6 s$.

- Parish Priest; His Duties, Acquirements and Obligations. Sixth Edition. Post 8vo. 6s.

Lectures on the Right Use of the Early Fathers. Third Edition. 8vo. 9s.

University Sermons. Second Edition. Post 8vo. 6s.

Plain Sermons. Sixth Edition. 2 vols. Post 8 vo. $12 s$.

BLOMFIELD'S (BISHOP) Memoir, with Selections from his Correspondence. By his Son. Second Edition. Portrait, post 8vo. 12s.

BOSWELL'S (J AMEs) Life of Samuel Johnson, LL.D. Including the Tour to the Hebrides. By Mr. Croker. A new and revised Library Edition. Portraits. 4 vols. 8 vo.

[In Preparation. 
BRACE'S (C. L.) Manual of Ethnology; or the Races of the Old World. Post 8vo. 6s.

BOOK OF COMMON PRAYER. Illustrated with Coloured Borders, Initial Letters, and Woodcuts. 8vo. 18.

BORROW'S (GEORGE) Bible in Spain; or the Journeys, Adventures, and Imprisonments of an Englishman in an Attempt to circulate the Scriptures in the Peninsula. Post 8vo. 5s.

Zincali, or the Gypsies of Spain; their Manners, Customs, Religion, and Language. With Portrait. Post $8 \mathrm{vo}$. 5s.

- Lavengro; The Scholar-The Gypsy-and the Priest. Post 8vo. $5 s$.

Romany Rye-a Sequel to "Lavengro." Post 8vo. 5s. Wild Wales : its People, Language, and Scenery. Post 8vo. 5s.

Romano Lavo-Lil; Word-Book of the Romany, or English Gypsy Language; with Specimens of their Poetry, and an account of certain Gypsyries. Post 8vo. 10s. $6 d$.

BRAY'S (Mrs.) Life of Thomas Stothard, R.A. With Portrait and 60 Woodcuts. 4 to. $21 s$.

Revolt of the Protestants in the Cevennes. With some Account of the Huguenots in the Seventeenth Century. Post 8vo. 10s.6d.

BRITISH ASSOCIATION REPOR'S. 8vo.

York and Oxford, 1831-32, 13s. 6d. Hull, 1853, 10s. 6d.

Cambridge, 1833, $12 s$.

Edinburgh, 1834, 15 s.

Dublin, 1835, 13s. $6 d$.

Bristol, 1836, 12s.

Liverpool, 1837, 16s. 6d.

Newcastle, 1838, $15 s$.

Birmingham, 1839, 13s. fd.

Glasgow, 1840, $15 s$.

Plymouth, 1841, 13s. 6d.

Manchester, 1842, 10s. $6 d$.

Cork, 1843, $12 s$.

York, 1844, 20 s.

Cambridge, 1845, $12 s$.

Southampton, 1846, 15 s.

Oxford, 1847, 18 s.

Swansea, 1848, $9 s$.

Birmingham, 1849, 10s.

Edinburgh, 1850, 15s.

Ipswich, 1851, 16s. $6 d$.

Belfast, 1552, $15 s$.

Liverpool, 1854, 18s.

Glasgow, 1855, $15 \mathrm{~s}$.

Cheltenham, 1856, 18s,

Dublin, 1857, 15s.

Leeds, 1858, 20 s.

Aberdeen, 1859, 15s.

Oxford, 1860, 25s.

Manchester, 1861, 15s.

Cambridge, 1862, $20 s$.

Newcastle, 1863, $25 s$.

Bath, 1864, 18s.

Birmingham, 1865, 25s

Nottingham, 1866, 24s.

Dundee, 1867, 26 .

Norwich, 1868, 25s.

Exeter, 1869, 22s.

Liverpool, 1870, $18 s$.

Edinburgh, 1871, $16 s$,

Brighton, $1872,24 s$.

Bradford, 1873, 25s.

BROUGH'ON'S (LORD) Journey through Albania, Turkey in Europe and Asia, to Constantinople. Illustrations. 2 Vols. $8 \mathrm{vo}$. 30 s. Visits to Italy. 2 Vols. Post 8vo. 18s.

BROWNLOW'S (LADY) Reminiscences of a Septuagenarian. From the year 1802 to 1815. Third Edition. Post 8vo. 7s.6d.

BRUGSCH'S (Professor) History of Ancient Egypt. Derived from Monuments and Inscriptions. New Edition. I'ranslated by $\mathbf{H}$.

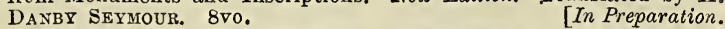

BURGON'S (REv. J. W.) Christian Gentleman ; or, Memoir of Patrick Fraser Tytler. Second Edition. Post 8vo. 9s.

Letters from Rome. Post 8vo. $12 s$.

BURN'S (Cox.) Dictionary of Naval and Military Technical Terms, English and French-French and English. Fourth Edition, Crown 8vo. 15s.

BURROW'S (Moñtagu) Constitutional Progress. A Series of Lectures delivered before the University of Oxford. 2nd Edition. Post 8vo. $5 s$. 
BUXTON'S (Charles) Memoirs of Sir Thomas Fowell Buxton, Bart. With Selections from his Correspondence. Portrait. 8vo. 16s. Popular Edition. Fcap. ๖vo. 5s.

Notes of Thought. With Biographical Sketch. By Rev. Llewellyn Davies. With Portrait. Crown 8vo. 10s. $6 \alpha$.

BURCKHARD'T'S (Dr. ЈАCOB) Cicerone; or Art Guide to Painting in Italy. Edited by Rev. Dr. A. VoN $\mathrm{Z}_{\mathrm{AHN}}$, and Translated from the German by Mrs. A. Clovgh. Post 8vo. $6 s$.

BYLES' (Sir JoHN) Foundations of Religion in the Mind and Heart of Man. Post 8 vo.

[Nearly ready.

BYRON'S (LoRD) Life, Letters, and Journals. By 'THoms Moore. Cabinet Edition. Plates. 6 Vols. Fcap. 8vo. 18s.; or One Volume, Portraits. Royal 8vo., 7s. 6d.

Portraits. 2 vols. Royal 8vo. 15s.

and Poetical Works. Popular Edition.

Poetical Works. Library Edition. Portrait. 6 Vol». Svo. $45 s$.

Cabinet Edition. Plates. $10 \mathrm{Vols}$. 12mo. $30 \mathrm{~s}$.

Pocket Edition. 8 Vols. $24 \mathrm{mo}$. 21s. In a case.

Popular Edition. Plates. Royal 8vo. 7s. $6 d$.

Pearl Edition. Crown 8vo. 2s. 6d.

Childe Harold. With 80 Engravings. Crown 8vo. $12 \mathrm{~s}$. 16mo. 2s. 6d.

Vignettes. $16 \mathrm{mo}$. Is.

Portrait. $16 \mathrm{mo} .6 d$.

Tales and Poems. 24mo. 2s. $6 d$.

Miscellaneous. 2 Vols. 24mo. 5s.

Dramas and Plays. 2 Vols. 24mo. $5 s$.

Don Juan and Beppo. 2 Vols. 24mo. $5 s$.

Beauties. Poetry and Prose. Portrait. F'cap. 8vo. 3s.6d.

BUTTMAN'S LEXILOGUS; a Critical Examination of the Meaning of numerous Greek Words, chiefly in Homer and Hesiod. By Rev. J. R. FishlaKe. Fifth Edition. 8vo. 12s.

IRREGULAR GREEK VERBS. With all the Tenses extant-their Formation, Meaning, and Usage, with Notes, by Rev. J. R. Fishlake. Fifth Edition. Post 8 vo. $6 s$.

CALLCOTT'S (LADr) Little Arthur's History of Fngland. New and Cheaper Edition, brought down to 1872. With Woodcuts. Fcap. 8vo. $1 s .6 d$.

CARNARVON'S (LoRD) Fortugal, Gallicia, and the Basque Provinces. Third Edition. Post 8vo. 3s.6d.

Reminiscences of Athens and the Morea. With Map. Crown 8vo. 7s.6d.

Recollections of the Druses of Lebanon. With Notes on their Religion. Third Edition. Post 8vo. 5s. $6 d$.

CASTLEREAGH (THE) DESPATCHES, from the commencement of the official career of Viscount Castlereagh to the close of his life. 12 Vols. 8vo. 14s, each. 
CAMPBELL'S (LoRD) Lord Chancellors and Keepers of the Great Seal of England. From the Earliest Times to the Death of Lord Eldon in 1838. Fifth Edition. 10 Vols. Crown 8vo. 6s. each.

Chief Justices of England. From the Norman Conquest to the Death of Lord Tenterden. Third Edition. 4 Vols. Crown 8 vo. $6 s$. each.

Lords Lyndhurst and Brougham. 8vo. 16s.

Shakspeare's Legal Acquirements. 8vo. 5s.6d.

Lord Bacon. Feap. 8vo. 2s. $6 d$.

(Sir NmIL) Account of Napoleon at Fontainebleau

and Elba. Being a Journal of Occurrences and Notes of his Conversations, dic. Portrait. 8vo. 15s.

(Srr Georas) India as it may be: an Outline of a proposed Government and Policy. 8vo.

(Tros.) Essay on English Poetry. With Short Lives of the British Poets. Post 8vo. 3s.6d.

CATHCART'S (Sir GEorae) Commentaries on the War in Russia and Germany, 1812-13. Plans. 8vo. 14s.

CAVALCASELLE AND CROWE'S History of Painting in Italy, from the 2nd to the 16th Century. With Illustrations. 5 Vols. 8vo. 21s. each.

Early Flemish Painters, their Lives and Works. Illustrations. Post 8vo. 10s. 6d.; or Large Paper, 8vo. 15s.

CHILD's (G. Chaplin, M.D.) Benedicite; or, Song of the Three Children; being lllustrations of the Power, Beneficence, and Design manifested by the Creator in his works. 10th Thousand. Post 8vo. 6s.

CHISHOLM'S (Mrs.) Perils of the Polar Seas; True Stories of Arctic Discovery and Adventure. Illustrations. Post 8vo. 6s.

CHURTON'S (ARCHDEACON) Gongora. An Historical Essay on the Age of Philip III. and IV. of Spain. With Translations. Portrait. 2 Vols. Small 8 vo. $12 s$.

New Testament. Edited with a Plain Practical Commentary for the use of Families and General Readers. With 100 Panoramic and other Views, from Sketches and Photographs made on the Spot. 2 vols. 8 vo. $21 s$.

CICERO'S LIFE AND TIMES. His Character as a Statesman, Orator, and Friend, with a Selection from hia Correspondence and Orations. By William ForsY'in, M.P. Third Edition. With Illustrations. 8vo. 10s. $6 d$.

CLARK'S (SrR JAMes) Memoir of Dr. John Conolly. Comprising a Sketch of the Treatment of the Iusane in Europe and America. With Portrait. Post 8vo. 10s. 6d.

CLIVE'S (Lord) Life. By Rev. G. R. Gleia. Post 8vo. 3s.6d.

CLODE'S (C. M.) Military Fcrees of the Crown ; their Administration and Government. 2 Vols. 8vo. 21s, each.

Administration of Justice under Military and Martial Law, as applicable to the Army, Navy, Marine, and Auxiliary Forces. 2nd Edition. 8vo. 12s.

COLCHESTER ('THE) PAPERS. The Diary and Correspondence of Charles Abbott, Lord Colchester, Speaker of the House of Commons 1802-1817. Portrait. 3 Vols. 8vo. $42 s$. 


\section{LIST OF WORKS}

CHURCH (THE) \& THE AGE. Eskays on the Principles and Present Position of the Anglican Church. 2 vols. 8vo. 26s. Contents :-

VOL. I.

Anglican Principles.-Dean Hook.

Modern Religious Thought.-Bishop Ellicott.

State, Church, and Synods.-Rev. Dr. Irons.

Religious Use of Taste--Rev. R. St. John Tyrwhitt.

Place of theLaity.-Professor Burrows Parish Priest.-Rev. Walsham How.

Divines of 16 th and 17th Centuies. -Rev. A. W. Haddan.

Liturgies and Ritual, Rev. M. F. Sadler.

Church \& Education.-Canon Barry.

Indian Missions.-Sir Bartle Frere.

Church and the People.-Rev. W. D. Maclagan.

Conciliation and Comprehension.Rev. Dr. Weir.
VoL. II.

Church and Pauperisn.-Earl Nelson. American Church,-Bishop of Western New Yolk.

Church and Science. - Prebendary Clark.

Ecclesiastical Law.-Isamr ard Brunel. Church \& National Education.Canon Norris.

Church and Universities.-Jolın G。 Talbot.

Toleration.-Dean Cowie.

Eastern Church and Anglican Communion.-Rev. Geo. Williams.

A Disestablished Church.-Dean of Cashel.

Christian Tradition.-Rev. Dr. Irons. Dogrna.-Rev. Dr. Weir.

Parochial Councils. - Archdeacon Chapman.

COLERIDGE'S (SAnder TAylor) Table-Talk. Portrait. 12mo. 3s.6d.

COLLINGWOOD'S (CотнвERT) Rambles of a Naturalist on the Shores and Waters of the China Sea. Being Observations in Natural History during a Voyage to China, \&c. With Illustrations. 8vo. 16s.

COLONIAL IIBRARY. [See Home and Colonial Library.]

COOK'S (Canon) Sermons Preached at Lincoln's Inn. 8vo. $9 s$.

COOKERY (Modern Domestro). Founded on Principles of Economy and Practical Knowledge, and adapted for Private Families. By a Lady. Woodcuts. Fcap. 8vo. 5s.

COOPER'S (T. T.) Travels of a Pioneer of Commerce on an Overland Journey from China towards India. Illustrations. 8vo. $1 \mathrm{t} s$.

CORNWALLIS (THE) Papers and Correspondence during the American War,-Administrations in India,-Union with Ireland, and Peace of Amiens. Second Edition. 3 Vols. 8vo. $63 s$.

COWPER'S (CodNTEss) Diary while Lady of the Bedchamber to Caroline Princess of Wales, 1714-20. Edited by Hon. Spencen CowPER. Second Edition. Portrait. 8vo. 10s.6d.

CRABBE'S (Rev. George) Life and Poetical Works. With Illustrations. Royal 8vo. $7 s$.

CROKER'S (J. W.) Progressive Geography for Children. Fifth Edition. 18mo. 1s.6d.

Stories for Children, Selected from the History of England. Fifteenth Edition. Woodcuts. 16mo. 2s.6d.

Boswell's Life of Johnson. Including the Tour to the Hebrides. New and revised Library Edition. Portraits. 4 vols. 8vo.

[In Preparation.

Essays on the Early Period of the French Revolution.

8vo. 15s.

Historical Essay on the Grillotine. Fcap. 8vo. $1 s$. 
CUMMING'S (R. GoRdon) Five Years of a Hunter's Life in the Far Interior of South Africa. Sixth Edilion. Woodcuts. Post 8vo. 6s.

CROWE'S AND CAVALCASELLE'S Lives of the Early Flemish Painters. Woodcuts. Post $8 \mathrm{vo}, 10 s .6 d_{\text {. }}$; or Large Paper, 8vo, $15 s$.

- History of Painting in Italy, from 2nd to $16 \mathrm{th}$ Century. Derived from Researches into the Works of Art in that Country. With 100 Illustrations, 5 Vols. 8vo. 21s. each.

CUNYNGHAME'S (SIR ARThuR) Travels in the Eastern Caucasus, on the Caspian, and Black Seas, in Daghestan and the Frontiers of Persia and 'Turkey. With Map and Illustrations. 8vo. $18 s$.

CURTIUS' (Profensor) Student's Greek Grammar, for the Upper Forms. Edited by Dr. Wr. Sмiтr. Post 8vo. 6s.

Elucidations of the above Grammar. Translated by Evelyn Aвbot. Post 8vo. $7 s .6 d$.

- Smaller Greek Grammar for the Middle and Lower Forms. Abridged from the larger work. $12 \mathrm{mo}, 3 \varepsilon .6 d$.

Accidence of the Greek Language. Extracted from the above work. $12 \mathrm{mo} .2 s .6 d$.

Principles of Greek Etymology. Translated by A. S. Wilkins, M.A., and E. B. England, B.A. 8vo. Nearly Ready.

CURzoN'S (Hon. Robert) Armenia and Erzeroum. A Year on the Frontiers of Russia, Turkey, and Persia. Third Edition. Woodcuts. Post 8 vo. $7 s .6 d$.

Visits to the Monasteries of the Levant. Fifth Edition. Illustrations. Post 8vo. 7s. $6 d$.

CUST'S (GeneraL) Lives of the Warriors of the 17th Century-The Thirty Years' War. 2 Vols. 16s. Civil Wars of France and England. 2 Vols. 16s. Commanders of Fleets and Armies before the Enemy. 2 Vols. $18 s$.

Annals of the Wars-18th \& 19th Century, 1700-1815. With Maps. 9 Vols. Post 8vo. 5s. each.

DAVIS'S (NATHAN) Ruined Cities of Numidia and Carthaginia. Illustrations. 8จ0. $16 s$.

DAVY'S (Sir Humpery) Consolations in Travel; or, Last Days of a Philosopher. Seventh Edition. Woodcuts. Fcap.8vo. $3 s$ 6cl.

Salmonia; or, Days of Fly Fishing. Fifth Edition. Woodcuts. Fcap. 8vo. 3s. 6 d.

DARWIN'S (ChARLES) Journal of Researches into the Natural History of the Countries visited during a Voyage round the World. Eleventh Thousand. Post 8vo. 9s.

Origin of Species by Means of Natural Selection ; or, the Preservation of Favoured Races in the Struggle for Life. Sicth Edition. Post 8vo. $7 s .6 d$.

Variation of Animals and Plants under Domestication. With Illustrations. 2 Vols. 8vo. $28 s$.

Descent of Man, and Selection in Relation to Sex. With Illustrations. Crown 8 vo. $9 s$.

Expressions of the Emotions in Man and Animals. With Illustrations. Crown 8vo. 12s.

Fertilization of Orchids through Insect Agency, and as to the good of Intercrossing. Woodcuts. Post 8vo. $9 s$.

Fact and Argument for Darwin. By Fritz Muller. With numerous Illustrations and Additions by the Author. Translated from the German by W. S. DaLlas. Woodcuts. Pust 8vo. $6 s$. 
DELEPIERRE'S (Octave) History of Flemish Literature. 8vo. $9 s$. Historic Difficulties \& Contested Events. Post 8vo. 6s.

DENISON'S (E. B.) Life of Bishop Lonsdale. With Selections from his Writings. With Portrait. Crown 8vo. 10s.6d.

DERBY'S (EARL oF) lliad of Homer rendered into English Blank Verse. 7 th Edition. 2 Vols. Post 8vo. 10s.

DE ROS'S (LoRD) Young Officer's Companion; or, Essays on Military Duties and Qualities : with Examples and Illustrations from History. Post 8vo. 9s.

DEUTSCH'S (Eranuex) Talmud, Islam, The Targums and other Literary Remains. 8vo. $12 s$.

DOG-BREAKING; the Most Expeditious, Certain, and Easy Method, whether great excellence or only mediocrity be required. With a Few Hints for those who Love the Dog and the Gun. By LiEUT.GeN. Hutchinson. Fifth Edition. With 40 Woodcuts. Crown 8vo. 9s.

DOMESTIC MODERN COOKERY. Founded on Principles of Economy and Practical Knowledge, and adapted for Private Families. Woodcuts. Fcap. 8vo, $5 s$.

DOUGLAS'S (Sin HowARD) Life and Adventures. Portrait. 8vo. 15s. Theory and Practice of Gunnery. Plates. 8vo. $21 \mathrm{~s}$. Construction of Bridges and the Passage of Rivers, in Military Operations. Plates. Svo. 21s.

(Wy.) Horse-Shoeing; As it Is, and As it Should be. Illustrations. Post 8 vo. 7s. 6 .

DRAKE'S (Sir Francis) Life, Voyages, and Exploits, by Sea and Land. By JoHn Barrow. Third Edition. Post 8vo. 2s.

DRINKWATER'S (JоHN) History of the Siege of Gibraltar, 1779-1783. With a Description and Account of that Garrison from the Earliest Periods. Post 8vo, 2s.

DUCANGE'S MEDIEVAL LATIN-ENGLISH DICTIONARY. Translated by Rev. E. A. DAYMAN, M.A. Small 4to. [In preparation.

DU CHAILLU'S (PAUI B.) EQUATORIAL AFRICA, with Accounts of the Gorilla, the Nest-building Ape, Chimpanzee, Crocodile, \&c. Illustrations. 8vo. 21 s.

Journey to Ashango Land; and Further Penetration into Equatorial Africa. Illustrations. 8vo. 21 .

DUFFERIN'S (LoRD) Letters from High Latitudes; an Account of a Yacht Voyage to Iceland, Jan Mayen, and Spitzbergen. Fifth Edition. Woodcuts. Post 8vo. 7s.6d.

DUNCAN'S (MAJor) History of the Royal Artillery. Compiled from the Original Records. Second Edition. With Portraits. 2 Vols. 8vo. $30 s$.

DYKR'S (Tнов. H.) History of Modern Europe, from the taking of Constantinople by the Turks to the close of the War in the Crimea. With Index, 4 Vols. 8vo. $42 s$.

EASTLAKE:S (Sir CHARLES) Contributions to the Literature of the Fine Arts. With Memoir of the Author, and Selections from his Correspondence. By LADY EASTLAKE. 2 Vols. 8vo. 24s.

EDWARDS' (W. H.) Voyage up the River Amazons, including a Visit to Para. Post 8vo. 2s. 
ELDON'S (LorD) Public and Private Life, with Selections from his Correspondence and Diaries. By HoRACE Twiss. Third Edition. Portrait. 2 Vols. Post 8vo. 21s.

ELGIN'S (LORD) Letters and Journals. Edited by THEodore Walrond. With Preface by Dean Stanley. Second Edition. 8vo. 14s.

ELLESMERE'S (LoRD) Two Sieges of Vienna by the Turks. Translated from the German. Post 8vo. 2s.

ELLIS'S (W.) Madagascar, including a Journey to the Capital, with notices of Natural History and the People. Woodcuts. 8vo. 16s.

Madagascar Revisited. Setting forth the Persecutions and Heroic Sufferings of the Native Christians. Illustrations. 8vo. $16 s$.

Memoir. By His Son. With his Character and Work. By Rev. Henry Allon, D.D. Portrait. Svo. 10s.6d. (Robinson) Poems and Fragments of Catullus. $16 \mathrm{mo} .5 \mathrm{~s}$.

ELPHINSTONE'S (HoN. MIOUNTSTUART) History of India-the Hindoo and Mahomedan Periods. Sixth Edition. Map. 8vo. $18 s$.

(H. W.) Patterns for Turning; Comprising Elliptical and other Figures cut on the Lathe without the use of any Ornamental Chuck. With 70 Illustrations. Small 4to. 15 s.

ENGEL'S (CARL) Music of the Most Ancient Nations ; particularly of the Assyrians, Egyptians, and Hebrews; with Special Reference to the Discoveries in Western Asia and in Egypt. Second Edition. With 100 Illustrations. $8 \mathrm{vo}$. $10 \mathrm{~s}, 6 \mathrm{~d}$.

engluand. See Calicott, Croker, Hume, Markham, Smimm, and StANHope.

ENGLISHWOMAN IN AMERICA. Post 8vo. 10s. $6 d$.

ESSAYS ON CATHEDRALS. With an Introduction. By DEAN Howson. 8vo. $12 \mathrm{~s}$.

CONTENTS.

Recollections of a Dean.-Bishop of Cathedral Churches of the Old FounCarlisle.

Cathedral Canons and their Work.Canor Norris.

Cathedrals in Ireland, Past and Fnture.-Dean of Cashel.

Cathedrals in their Missionary Aspect. -A. J. B. Beresford Hope.

Cathedral Foundations in Relation to Religious Thought.-Canon Westcott.

Welsh Cathedrals.-Canon Perowne.

Education of Choristers. - Sir F. Gore Ouseley.

Cathedral Schools.-Canon Durham.

Cathedral Reform.-Chancellor Massingberd.

Relation of the Chapter to the Bishop. Chancellor Benson.

A rchitecture of the Cathedral Churches.-Canon Venables.

ETHNOLOGICAL SOCIETY'S TRANSACTIONS. Vols. I. to VI. 8vo.

ELZE'S (KARL) Life of Lord Byron. With a Critical Essay on his Place in Literature. Translated from the German, and Edited with Notes. With Original Portrait and Facsimile. 8vo. 16s.

FAMILY RECEIPT-BOOK. A Collection of a Thousand Valuable and Useful Receipts. Fcap. 8vo. 5s.6d.

FARRAR'S (A. S.) Critical History of Free Thought in reference to the Christian Religion. 8vo. 16s.

(F. W.) Origin of Language, based on Modern Researches, Fcap. 8vo. 5s. 
FERGUSSON'S (JAMES) History of Architecture in all Countries from the Earliest Times. Vols. I. and II. Ancient and Mediæral. With 1,000 Illustrations. Medium 8vo. 63s.

Wol. III. Indian and Eastern. With 30 E Illustrations. Medium 8vo.

[In the Fress. Medium 8vo. 31s.6d. Modern. With 330 Illustrations.

and Uses. Wude Stone Monuments in all Countries 230 Illustrations. Medium 8vo. 24s.

Holy Sepulchre and the Temple at Jerusalem. Woodcuts. 8vo. 7s. $6 d$.

FLEMING's (Professor) Student's Manual of Moral Philosophy. With Quotations and References. Post 8vo. $7 s .6 d$.

FLoWER GARDEN. By Rev. Thos. James. Fcap. 8vo. $1 s$.

FORD'S (RICHARD) Gatherings from Spain. Post 8vo. 3s. $6 d$.

FORSYTH'S (WILliam) Life and Times of Cicero. With Selections from his Correspondence and Orations. Third Edition. Illustrations. 8vo. $10 s, 6 d$.

Hortensius; an Historical Essay on the Office and Duties of an Advocate. Second Edition. Illustrations. 8vo. 12s. History of Ancient Manuscripts. Post 8vo. 2s. $6 d$.

Novels and Novelists of the 18 th Century, in Illustrat on of the Manners and Morals of the Age. Post 8vo. 10s. 6d.

FORTUNE'S (RoвerT) Narrative of Two Visits to the Tea Countries of China, 1843-52. Third Edition. Woodcuts. 2 Vols. Post 8vo. 18s.

FOSS' (Edward) Biographia Juridica, or Biographical Dictionary of the Judges of England, from the Conquest to the Present Time,
1066-1870. Medium 8vo. 21s.

Tabulæ Curiales; or, Tables of the Superior Courts of Westminster Hall. Showing the Judges who sat in them from 1066 to 1864 . ovo. $10 s, 6 d$.

FRANCE. *** See MarkHaM, Suith, Student's.

FRENCH (THE) in Algiers; The Soldier of the Foreign Legionand the Prisoners of Abd-el-Kadir. Translated by Lady DCFr Gordon. Post 8vo. 2s.

FRERh'S (Sir Bartle) Indian Missions. Third Edition. Small 8 vo. $2 s .6 d$.

- Eastern Africa as a field for Missionary Labour. With Map. Crown 8vo. $5 s$.

Bengal Famize. How it will be Met and How to Prevent Future Famines in Incia. With Maps. Crown 8vo. $5 s$.

(M.) Old Deccan Days; or Fairy Legends Current in Southern India. With Notes, by Sir BartLe Frere. With Illustrations. Fcap. 8vo. 6s.

GALTON'S (FraNCIS) Art of Travel; or, Hints on the Shifts and Contrivances available in Wild Countries. Fifth Edition. Woodcuts. Post 8vo. $7 s .6 d$.

GEOGRAPHICAL SOCIEI Y'S JOURNAL. (Published Yearly.)

GEURGE'S (ERnEst) Mosel; a Series of Twenty Etchings, with Descriptive Letterpress. Imperial 4to. $42 s$.

Loire and South of France; a Series of Twenty Etchings, with Descriptive Text. Folio. 423.

GERMANY (History of). See MarkHaM. 
GIBBON'S (EDward) History of the Decline and Fall of the Roman Empire. Edited by MrLman and Guizot. A New Edition. Edited, with Notes, by Dr. WM. Smitr. Maps. 8 Vols. 8vo. 60s.

(The Student's Gibbon); Being an Epitome of the above work, incorporating the Researches of Recent Commentators. By Dr. WM. SмIтн. Woodcuts. Post 8 vo. $7 s .6 d$.

GIFFARD'S (EDWARD) Deeds of Naval Daring; or, Anecdotes of the British Navy. Fcap. 8vo. 3s. $6 d$.

GLADSTONE'S (W. E.) Financial Statements of 1853, 1860, 63-65. 8vo. $12 s$.

GLEIG'S (G. R.) Campaigns of the British Army at Washington and New Orleans. Post 8vo. 2s.

Story of the Battle of Waterloo. Post 8vo. 3s. $6 d$.

Narrative of Sale's Brigade in Affghanistan. Post 8vo.2s.

Life of Lord Clive. Post 8vo. 3s. $6 d$.

Sir Thomas Munro. Post 8vo. 3s.6d.

gOLDSMITH'S (Outver) Works. Edited with Notes by Peter Conninghay. Vignettes. $4 \mathrm{Vols}$. 8vo. $30 \mathrm{~s}$.

GORDON'S (Sir Alex.) Sketches of German Life, and Scenes from the War of Liberation. Post 8vo. 3s. $6 d$.

_L (LADY DufF) Amber-Witch: A Trial for Witchcraft. Post svo. 2s.

French in Algiers. 1. The Soldier of the Foreign Legion. 2. The Prisoners of Abd-el-Kadir. Post 8vo. 2s.

Crammars. See Curtius ; HaLl; Hutton; King Edward ; Matthis; Maetzner; Smith.

GREECE. See Grote-Smith-Student.

GREY'S (EARL) Correspondence with King William IVth and Sir Herbert Taylor, from 1830 to 1832 . 2 Vols. 8 vo. $30 \mathrm{~s}$.

Parliamentary Government and Reform; with Suggestions for the Improvement of our Representative System. Second Edition. 8vo. $9 s$.

GRUNER'S (LEwIS) Terra-Cotta Architecture of North Italy, from careful Drawings and Restorations. With Illustrations, engraved and printed in Colours. Small folio. $5 l .5 s$.

GUIZOT'S (M.) Meditations on Christianity, and on the Religious Questions of the Day. Part I. The Essence. Part II. Present State. Part III. Relation to Society and Opinion. 3 Vols. Post 8vo. 30s.

GROTE'S (GEORGE) History of Greece. From the Earliest Times to the close of the generation contemporary with the death of Alexander the Great. Library Edition. Portrait, Maps, and Plans. 10 Vols. $8 \mathrm{vo}$. 120s. Cabinet Edition. Portrait and Plans. 12 Vols. Post 8vo. 6s. each.

- Prato, and other Companions of Socrates. 3 Vols. 8vo. $45 s$. Aristotre. Edited by Professors Bain and Robertson. 2 Vols. 8vo. $32 s$.

Minor Works. With Critical Remarks on his Intellectual Character, Writings, and Speeches. By A LEx.BAIN, LL.D. Portrait, 8vo. 14s.

- Personal Life. Compiled from Family Documents, Private Memoranda, and Original Letters to and from Various Friends. By Mrs. Grote. Portrait. 8vo. 12s.

(Mrs.) Memoir of Ary Scheffer. Portrait. 8vo. 8s. 6d. 
HALL'S (T. D.) School Manual of English Grammar. With Copious Exercises. $12 \mathrm{mo} .3 s .6 d$.

- Primary English Grammar for Elementary Schools. $16 \mathrm{mo} .1 s$.

- Child's First Latin Book, including a Systematic Treatment of the New Pronunciation, and a full Praxis of Nouns, Adjectives, and Pronouns. $16 \mathrm{mo} .18 .6 \mathrm{~d}$.

HALLAM'S (HEnry) Constitutional History of England, from the Accession of Henry the Seventh to the Death of George the Second. Library Edition. 3 Vols. 8vo. 30s. Cabinet Edition, 3 Vols. Post $8 v 0.12 s$. Student's Edition of the above work. Edited by Wx. Sмrт, D.C.L. Post 8vo. 7s. $6 d$.

History of Europe during the Middle Ages. Library Edition. 3 Vols. 8vo. 30s. Cabinet Edition, 3 Vols. Post 8vo. 12s.

- Student's Edition of the above work. Edited by Wл. Sмiтн, D.C.L. Post 8vo. 7s. $6 d$.

Literary History of Europe, during the 15th, 16th and 17th Centuries. Library Edition. 3 Vols. 8vo. 36s. Cabinet Edition. 4 Vols. Post 8 vo. $16 s$.

(ARTHUR) Literary Remains; in Verse and Prose. Portrait. Fcap. 8vo. 3s. $6 d$.

HAMILTON'S (GEN. SIR F. W.) History of the Grenadier Guards. From Original Documents in the Rolls' Records, War Office, Regimental Records, \&c. Wilh Illustrat ons. 3 Vols. 8vo. 6:3s.

HANNAH'S (Rev. Dr.) Divine and Human Elements in Holy Scripture. 8vo. 10s. 6d.

HART'S ARMY LIST. (Published Quarterly and Annually.)

HAY'S (Sir J. H. Drummond) Western Barbary, its Wild Tribes and Savage Animals. Post 8 vo. $2 s$.

HEAD'S (Sir Francis) Royal Engineer. Illustrations. 8vo. $12 s$. Jife of Sir John Burgoyne. Post 8vo. 1s.

- Rapid Journeys acrose the Pampas. Post 8vo. $2 s$.

- Bubbles from the Brunnen of Nassau. Illustrations. Post 8vo. $7 s .6 d$.

- Emigrant. Ficap. 8vo. 2s. 6d.

Stokers and Pokers ; or, the London and North Western Railway. Post 8 vo. $2 s$.

- (SIR EDmond) Shall and Will; or, Future Auxiliary Verbs. Fcap. 8 vo. $4 s$.

HEBER'S (Bishop) Journals in India. 2 Vols. Post 8vo. $7 s$.

Poetical Works. Portrait. Feap. 8vo. 3s. $6 d$.

- Hymns adapted to the Church Service. 16mo. 1s. $6 d$.

HERODOTUS. A New English Version. Edited, with Notes and Essays, historical, ethnographical, and geographical, by $\mathrm{C}_{A x O N}$ RAWLINSON, assisted by SIR HENRY RAWLINSON and SIR J.G. WILKINSON. Third Edition. Maps and Woodcuts. 4 Vols. 8vo.

HATHERLEY'S (LORD) Continuity of Scripture, as Declared by the Testimony of our Lord and of the Evangelists and Apostles. Fourth Edition. 8vo. 6s. Popular Edition. Post 8vo. 2s. $6 d$.

HOLLWAY'S (J. G.) Month in Norway. Feap. 8vo. $2 s$.

HONEY BEE. By Rev. Thomas James. Fcap. 8vo. 1s.

HOOK'S (DEAr) Church Dictionary. Tenth Edition. 8vo. 163. (Theodore) Life. By J. G. Locrhart. Fcap. 8vo. $1 s$. 
HOPE'S (T. C.) ARCHITECTURE OF AHMEDABAD, with Historical Sketch and Architectural Notes. With Maps, Photographs, and Woodcuts. 4to. $5 l .5 s$.

- (A. J. Beresford) Worship in the Church of England, 8vo. $9 s$.

\section{FOREIGN HANDBOOKS.}

HAND-BOOK-TRAVEL-TALK. English, French, German, and Italian. $18 \mathrm{mo}$. $3 s .6 d$.

HOLLAND,-Bergium, and the Rhine to Mayence. Map and Plans. Post 8 vo. $6 s$.

NORTH GERMANY,-PRUSSIA, SAXONX, HANover, and the Rhine from Mayence to Switzerland. Map and Plans. Post 8 vo. 6s.

SOUTH GERMANY,-Bavaria, Austria, Styria, Salzburg, the Austrian and Bavarian Alps, the Tyrol, Hungary, and the Danube, from Ulm to the Black Sea. Map. Post 8vo. 10s.

KNAPSACK GUIDE TO THE TYROL. $16 \mathrm{mo} .6 s$.

PAINTING. German, Flemish, and Dutch Schools. Illustrations. 2 Vols. Post 8 vo. $24 s$.

LIVES OF EARLY FLEMISH PAINTERS. By

Crowe and CaVAlCaselle. Illustrations. Post 8vo. 10s. $6 d$.

SWITZERLAND, Alps of Savoy, and Piedmont.

Maps. Post 8vo. 9s.

FRANCE, Normandy, Brittany, the French Alps, the Rivers Loire, Seine, Rhone, and Garonne, Dauphiné, Provence, and the Pyrenees. Maps. 2 Parts. Post 8vo. 12s.

ISLANDS OF THE MEDITERRANEAN-Malta, Corsica, Sardinia, and Sicily. Maps. Post 8 ro.

ALGERIA. Map. Post 8vo. $9 s$.

PARIS, and its Environs. Map. 16mo. 3s. $6 \mathrm{~d}$.

** Murray's Plan of Paris, mounted on canvas. 3s. $6 d$.

SPAIN, Madrid, The Castiles, The Basque Provinces, Leon, The Asturias, Galicia, Estremadura, Andalusia, Ronda, Granada, Murcia, Valencia, Catalonia, Aragon, Navarre, The Balearic Islands, \&c. \&c. Maps. 2 Vols. Post 8 vo. $24 s$.

POR'TUGAL, Lisbon, Porto, Cintra, Mafra, \&c. Map. Post 8 ro. $9 s$.

NORTH ITALY, Piedmont, "Liguria, Venetia,

Lombardy, Parma, Modena, and Romagna. Map. Post 8vo. 10s.

CENTRAL ITALY, Lucca, Tuscany, Florence, The

Marches, Umbria, and the Patrimony of St. Peter's. Map. Post 8vo. 10s. ROME AND ITs Environs. Map. Post 8vo. 10s. SOUTH ITALY, Two Sicilies, Naples, Pompeii, Herculaneum, and Vesmvius. Map. Post 8vo. 10s.

KNAPSACK GUIDE TO ITALY. 16mo.

PAINTING. The Italian Schools. Illustrations.

2 Vols. Post 8 vo. 30 s.

LIVES OF ITALIAN PAINTERS, FROM CIMABUE

to Bassano. By Mrs. Jameson. Portraits. Post 8vo. $12 s$.

RUssia, St. Petersbura, Moscow, Pouand, and

Finland. Maps. Post 8vo. $15 s$.

DENMARK. Map. Post 8vo. 6s. 
HAND-BOOK-SWEDEN. Map. Post 8vo. $6 s$. NORWAY. Map. $6 s$.

GREECE, the Ionian Islands, Continental Greece, Athens, the Feloponnesus, the Islands of the Aggean Sea, Albania, Thessaly, and Macedonia. Maps. Post 8vo. 15s.

TURKEY IN ASIA-Constantinople, the Bos. phorus, Dardanelles, Brousa, Plain of Troy, Crete, Cyprus, Smyrna, Ephesus, the Seven Churches, Coasts of the Black Sea, Armenia, Mesopotamia, \&c. Maps. Post 8vo. 15s.

FGYPT, including Descriptions of the Course of the Nile through Egypt and Nubia, Alexandria, Cairo, and Thebes, the Suez Canal, the Pyramids, the Peninsula of Sinai, the Oases, the Fyoom, \&c. Map. Post 8vo. 15s

HOLY LAND - Sxria Palestine, Peninsula of Sinai, Edom, Syrian Desert, \&c. Maps. Post $8 \mathrm{vo}$.

INDIA - Bombay and Madras. Map. 2 Vols.

Post 8vo, 12s, each.

\section{ENGLISH HANDBOOKS.}

HAND-BOOK-MODERN LONDON. Map. 16mo. 3s. $6 d$. ESSEX, CAMBRIDGE, SUFFOLK, AND NORFOLK, Chelmsford, Colchester, Maldon, Cambridge, Ely, Newmarket, Bury, Ipswich, Woodbridge, Felixstowe, Lowestoft, Norwich, Yarmouth, Cromer, \&c. Map and Plans. Post 8vo. 12s.

CATHEDRALS of Oxford, Peterborough, Norwich, Ely, and Lincoln. With 90 Illustrations. Crown 8vo. $18 s$.

KENT AND SUSSEX, Canterbury, Dover, Ramsgate, Sheerness, Rochester, Chatham, Woolwich, Brighton, Chichester, Worthing, Hastings, Lewes, Arunde!, \&c. Map. Post 8vo. $10 s$.

SURREY AND HANTS, Kingston, Croydon, Reigate, Guildford, Dorking, Boxhill, Winchester, Southampton, New Forest, Portsmouth, and IsLE OF WIGHT. Maps. Post 8vo. 10s.

BERKS, BUCKS, AND OXON, Windsor, Eton, Reading, Aylesbury, Uxbridge, Wycombe, Henley, the City and University of Oxford, Blenheim, and the Descent of the Thames. Map. Post 8vo. 7s. 6d.

WIL'S, DORSET, AND SOMERSET, Salisbury, Chippenham, Weymouth, Sherborne, Wells, Bath, Bristol, Taunton, \&c. Map. Post 8vo. 10s.

DEVON AND CORNWALL, Exeter, Ilfracombe, Linton, Sidmouth, Dawlish, Teignmouth, Plymouth, Devonport, Torquay, Launceston, Truro, Penzance, Falmouth, the Lizard, Land's End, \&c. Maps. Post 8vo. 12s.

CATHEDRALS of Winchester, Salisbury, Exeter, Wells, Chichester, Rochester, Canterbury. With 110 Illustrations. 2 Vols. Crown 8 vo. $24 s$.

GLOUCESTER, HEREFORD, AND WORCESTER, Cirencester, Cheltenham, Stroud, Tewkesbury, Leominster, Ross, Malvern, Kidderminster, Dudley, Bromsgrove, Evesham. Map. Post 8vo. $9 s$.

CATHEDRALS of Bristol, Gloucester, Hereford, Worcester, and Lichfield. With 50 Illustrations. Crown 8vo. $16 s$. NORTH WALES, Bangor, Carnarvon, Beaumaris, Snowdon, Llanberis, Dolgelly, Cader Idris, Conway, \&c. Map. Post 8vo. $7 s_{\text {. }}$

SOUTH WALES, Monmouth, Llandaff, Merthyr, Vale of Neath, Pembroke, Carmarthen, Tenby, Swansea, and The Wye, \&c. Map. Post 8vo. 7s. 
HAND-BOOK-CATHEDRALS OF BANGOR, ST. ASAPH, Llandaff, and St. Daviu's. With Illustrations. Post 8vo. 15s.

DERBY, NOTTS, LEICESTER, STAFFORD, Matlock, Bakewell, Chatsworth, The Peak, Buxton, Hardwick, Dove Dale, Ashborne, Southwell, Mansfield, Retford, Burton, Belvoir, Melton Mowbray, Wolverhampton, Lichfield, Walsall, Tamworth. Map. Post 8vo. 9s.

SHROPSHIRE, CHESHIRE AND LANCASHIRE

-Shrewsbury, Ludlow, Bridgnorth, Oswestry, Chester, Crewe, Alderley, Stockport, Birkenhead, Warrington, Bury, Manchester, Liverpool, Burnley, Clitheroe, Bolton, Blackburn, Wigan, Preston, Rochdale, Lancaster, Sonth port, Blackpool, \&c. Map. Post 8vo. 10s. YORKSHIRE, Doncaster, Hull, Selby, Beverley, Scarborough, Whitby, Harrogate, Ripon, Leeds, Wakefield, Bradford, Halifax, Huddersfield. Sheffield. Map and Plans. Post 8vo. 12s. CATHEDRALS of York, Ripon, Durham, Carlisle, Chester, and Manchester. With 60 Illustrations. 2 Vols. Crown 8vo. $21 s$.

DURHAM AND NORTHUMBERLAND, Newcastle, Darlington, Gateshead, Bishop Auckland, Stock ton, Ha rtlepool, Sunderland, Shields, Berwick-on-Tweed, Morpeth, Tynemouth, Coldstream, Alnwick, \&c. Map. Post 8vo. 9s.

WESTMORLAND AND CUMBERLAND-Lancaster, Furness Abbey, Ambleside, Kendal, Windermere, Coniston, Keswick, Grasmere, Ulswater, Carlisle, Cockermouth, Penrith, Appleby, Map. Post 8vo. 6s.

* * Murrax's Map of the Lake District, on cantas. 3s. $6 d$. SCOTLAND, Edinburgh, Melrose, Kelso, Glasgow, Dumfries, Ayr, Stirling, Arran, The Clyde, Oban, Inverary, Loch Lomond, Loch Katrine and Trossachs, Caledonian Canal, Inverness, Perth, Dundee, Aberdeen, Braemar, Skye, Caithness, Ross, Sutherland, \&c. Maps and Plans. Post 8vo. 9s.

IRELAND, Dublin, Belfast, Donegal, Galway, Wexford, Cork, Limerick, Waterford, Killarney, Munster, \&c. Maps. Post 8vo. 12s.

FAMILIAR QUOTATIONS. From English Authors. Third Edition. Fcap. 8vo. 5s.

HORACE; a New Edition of the Text. Edited by Dean Mruman. With 100 Woodcuts. Crown 8vo. $7 s .6 d$.

Life of. By Dean Milman. Illustrations. 8vo. 9s.

HOUGHTON'S (LoRD) Monographs, Personal and Social. With Portraits. Crown 8vo, 10s. $6 d$.

HUME'S (The Student's) History of England, from the Invasion of Julius Cæsar to the Revolution of 1688. Corrected and continned to 1868 . Woodcuts. Post $8 \mathrm{vo}, 7 s, 6 d$.

HUTCHINSON (GEN.), on the most expeditious, certain, and easy Method of Dog-Breaking. Fifth Edition. With 40 Illustrations. Crown 8 vo. $9 s$.

HUTTON'S (H. E.) Principia Græca; an Introduction to the Study of Greek. Comprehending Grammar, Delectus, and Exercise-book, with Vocabularies. Sixth Edition. 12mo. 3s.6d.

IRBY AND MANGLES' Travels in Egypt, Nubia, Syria, and the Holy Land. Post 8vo. 2s.

JACOBSON'S (BISHOP) Fragmentary Illustrations of the History of the Book of Common Prayer; from Manuscript Sources (Bishop SANDERSON and Bishop Wren). 8vo. $5 s$.

JAMES' (Rev. Thomas) Fables of Esop. A New Translation, with Historical Preface. With 100 Woodcuts by TeNeIEL and Wolf. Sixty-fourth Thousand. Post 8vo. 2s.6d. 
HOME AND COLONIAL LIBRARY. A Series of Works adapted for all circles and classes of Readers, having been selected for their acknowledged interest, and ability of the Authors. Post 8vo. Published at $2 s$, and $3 s .6 d$. each, and arranged under two distinctive heads as follows :-

CLASS A.

\section{HISTORY, BIOGRAPHY, AND HISTORIC TALES.}

1. SIEGE OF GIBRALTAR. By JOHN DRINKWATER. $2 s$.

2. THE AMBER-WITCH. BY LADY DUFF GORDON. $2 s$.

3. CROMWELL AND BUNYAN. By Robert SOUTHEx. $2 s$.

4. LIFE OF SIR FRANCIS DRAKE. By JOHN BARrow. 2s.

5. CAMPAIGNS AT WASHINGTON. By Rev. G. R. Gleig. $2 s$.

6. THE FRENCH IN ALGIERS. By Ladx DUfa Gordon. $2 s$.

7. THE FALL OF THE JESUITS. $2 s$.

8. LIVONIAN TALES. $2 s$.

9. LIFE OF CONDÉ. By LORD MAHON. $3 s, 6 d$.

10. SALE'S BRIGADE. By REV. G. R. Gleig. $2 s$.
11. THE SIEGES OF VIENNA. By Lond Ellesmere. $2 s$.

12. THE WAYSIDE CROSS. By Capt. Milman. $2 s$.

13. SKETCHES OF GERMAN LIFE. By Sir A. Gordon, 3s. $6 d$.

14. THE BATTLE OF WATERLOO. By Rev. G. R. GLeig. 3s.6d.

15. AUTOBIOGRAPHY OF STEF. FENS. $2 s$.

16. THE BRITISH POETS. By Thomas CaMpBell. $3 s .6 d$.

17. HISTORICAL ESSAYS. By LORD MAHON. $3 s .6 d$.

18. LIFE OF LORD CLIVE. By Rev. G. R. Gleig. $3 s .6 d$.

19. NORTH - WESTERN RAILWAY. BY SIR F.B. HEAD. $2 s$.

20. LIFE OF MUNRO. By REv, G. R. Gleig. 3s. $6 d$.

CLASS B.

\section{VOYAGES, TRAVELS, AND ADVENTURES.}

1. BIBLE IN SPAIN. By George BORROW. 3s. $6 d$.

2. GYPSIES OF SPAIN. By GEORGE BORROW. $3 s, 6 d$.

3 \& 4. JOURNALS IN INDIA. By Bishop HEBER. 2 Vols. $7 s$.

5. TRAVELS IN THE HOLY LAND. By Irby and Mangles. $2 s$.

6. MOROCCO AND THE MOORS. By J. Drummond Hay. $2 s$.

7. LETTERS FROM THE BALTIC. By a LADY. $2 s$.

8. NEW SOUTH WALES. By Mrs. MEREDITH. $2 s$.

9. THE WEST INDIES. By M. G. LEWIS. $2 s$.

10. SKETCHES OF PERSIA. By Sir John Malcolm. 3s. $6 d$.

11. MEMOIRS OF FATHER RIPA. $2 s$.

12 \& 13. TYPEF AND OMOO. By Hermann Melville. 2 Vols. $7 s$.

14. MISSIONARY IIFE IN CANADA. By Rev. J. Aввотt. $2 s$.
15. LETTERS FROM MADRAS. By a LADY. $2 s$.

16. HIGHLAND SPORTS. By Charles St. John. $3 s, 6 d$.

17. PAMPAS JOURNEYS. By Sir F. B. HEAD. $2 s$.

18. GATHERINGS FROM SPAIN. By Richard Ford. $3 s, 6 d$.

19. THE RIVER AMAZON. By W. H. EDWARDE. $2 s$.

20. MANNERS \& CUSTOMS OF INDIA. By Rev. C. ACland. $2 s$.

21. ADVENTURES IN MEXICO. By G. F. Ruxton. $3 s .6 d$.

22. PORTUGAL AND GALLICIA. By Lord Carnarvon. $3 s .6 d$.

23. BUSH LIFE IN AUSTRALIA. By Rev. H. W. HA YGaRTH. $2 s$.

24. THE LIBYAN DESERT. By BAyle St. JoHn, $2 s$.

25. SIERRA LEONE. By A LADY. $3 s .6 d$.

\footnotetext{
* Fach work may be had separately.
} 
JAMESON'S (MRs.) Lives of the Early Italian Paintersand the Progress of Painting in Italy-Cimabue to Bassano. New Edition. With 50 Portraits. Post 8 vo. $12 s$.

JENNINGS' (L. J.) Eighty Years of Republican Government in the United States. Post 8vo. 10s. $6 d$.

JERVIS'S (REv. W. H.) Gallican Church, from the Concordat of Bolngna, 1516, to the Revolution. With an Introduction. Portraits. 2 Vols. 8 vo. $28 s$.

JEGSE'S (EDWARD) Gleanings in Natural History. Fep. 8vo. 3s. 6d.

JOHNS' (Rev. B. G.) Blind People; their Works and Ways. With Sketches of the Lives of some famous Blind Men. With Illustrations. Post 8 vo. $7 s .6 d$.

JOHNSON'S (Dr. SAyuez) Life. By James Boswell. Including the Tour to the Hebrides. Edited by Mr. Crokrr. New revised Library Edition. Portraits. 4 Vols. 8vo. [In Preparation.

Lives of the most eminent English Poets, with Critical Observations on their Works. Edited with Notes, Corrective and Explanatory, by Peter Cunningham. 3 vols. 8 vo. 22s. $6 d$.

JUNiUS' Handwriting Professionally investigated. By Mr. Снавот, Expert. With Preface and Collateral Evidence, by the Hon. EDward Twisleton. With Facsimiles, Woodcuts, \&c. 4to. \&33 $3 s$.

KEN'S (Bishop) Life. By a Layman. Portrait. 2 Vols. 8vo. 18s. Exposition of the Apostles' Creed. 16mo. 1s. $6 d$.

KERR'S (Robert) GENTLEMAN'S HOUSE; oR, How to PlaN English Residences, from the Parsonage to the Palace. Third Edition. With Views and Plans. 8vo. 24s.

- Small Country House. A Brief Practical Discourse on the Planning of a kesidence from 2000l, to 5000l. With Supplementary Estimates to 7000l. Post 8vo. 3s.

Ancient Lights; a Book for Architects, Surveyors, Lawyers, and Landlords. 8vo. 5s. $6 d$.

(R. Malcolm) Student's Blackstone. A Systematic Abridgment of the entire Commentaries, adapted to the present state of the law. Post 8vo. 7s. $6 d$.

KING EDWARD VIrn's Latin Grammar. Seventeenth Edition. 12mo. $3 s .6 d$.

12mo. 2s.6d.

First Latin Book. Fifth Edition.

KING GEORGE IIIRD's CORRESPONDENCE WITH LORD NORTH, 1769-82. Edited, with Notes and Introduction, by W. BODHAM DONNE. 2 vols. 8 vo. $32 s$.

KING'S (R. J.) Sketehes and Studies; Historical and Descriptive. 8vo. 12s.

KIRK'S (J. Foster) History of Charles the Bold, Duke of Burgundy. Portrait. 3 Vols. 8 vo. $45 s$.

KIRKES' Handbook of Physiology. Edited by W. Morrant BAKER, F.R.C.S. Eighth Edit. With 240 Illustrations. Post 8vo. $12 s .6 d$.

KUGLER'S Hardbook of Painting.-The Italian Schools. Fourth Edition. Revised and Remodelled from the most recent Researches. By LAdY EAstlake. With 140 Illnstrations. 2 Vols. Crown 8vo. 30s.

Handbook of Painting.-The German, Flemish, and Dutch Schools. Third Edition. Kevised and in part re-written. By J. A. Crowe. With 60 Illustrations. 2 Vols. Crown 8vo. $24 s$.

LANE'S (E. W.) Account of the Manners and Customs of Modern Egyptians. New Edition. Witl Illustrations. 2 Vols. Post8vo. 12s.

LAWRENCE's (SIR GEO.) Reminiecences of Forty-three Years; Service in India; including Captivities in Cabul among the Affohans and among the Sikhs, and a Narrative of the Mutiny in Rajputana. Edited by W. EDWarids, II.M.C.B.S. Crown 8 vo. 10s. $6 d$. 
LAYARD'S (A. H.) Nineveh and its Remains. Being a Narrative of Researches and Discoveries amidst the Ruins of Assyria. With an Account of the Chaldean Christians of Kurdistan; the Yezedis, or Devil-worshippers; and an Enquiry into the Manners and Arts of the Ancient Assyrians. Sixth Edition. Plates and Woodcuts. 2 Vols. 8vo. 36s.

** A Popdlar Edition of the above work. With Inustrations. Post 8 vo. $7 s .6 d$.

Nineveh and Babylon; being the Narrative of Discoveries in the Ruins, with 'Travels in Armenia, Kurdistan and the Desert, during a Second Expedition to Assyria. With Map and Plates. 8vo. $21 s$.

$*^{*}$ A PopUlar Editios of the above work. With Illustrations. Post 8vo. $7 s, 6 d$.

LEATHES' (Stanley) Practical Hebrew Grammar. With the Hebrew Text of Genesis i.-vi., and Psalms i.-vi. Grammatical Analysis and Vocabulary. Post 8vo. $7 s, 6 d$.

LENNEP'S (Rev. H. J. VAN) Missionary Travels in Asia Minor. With Illustrations of Biblical History and Archæology. With Map and Woodcuts. 2 Vols. Post 8vo. 24s.

LESLIE'S (C. R.) Handbook for Young Painters. With Illustrations. Post 8vo. $7 s .6 d$.

- Life and Works of Sir Joshua Reynolds. Portraits and Illustrations. 2 Vols. $8 \mathrm{vo}$. $42 s$.

LETTERS From the Battic. By a Lady. Post 8vo. $2 s$.

Madras. By a Lady. Post 8vo. 2s.

Sierra Leone. By a Lady. Post 8vo. 3s. $6 r$.

LEVI'S (LEONE) History of British Commerce; and of the Economic Progress of the Nation, from 1763 to 1870. 8vo. $16 s$.

LEWIS'S (M. G.) Journal of a Residence among the Negroes in the West Indies. Post 8vo. 2s.

LIDDELL'S (DeAN) Student's History of Rome, from the earliest Times to the establishment of the Empire. With Woodcuts. Post $\delta$ vo. $7 s .6 d$.

IINDSAY'S (LORD) Lives of the Lindsays; Memoir of the Houses of Crawfurd and Balcarres. With Extracts from Official Papers and Personal Narratives. 3 Vrols. 8vo. 24s.

- Etruscan Inscriptions. Analysed, Translated, and Commented upon. 8vo. 123.

LLOYD'S (W. WATRISS) History of Sicily to the Athenian War; with Elucidations of the Sicilian Odes of Pindar. With Map. 8vo.14s.

LISPINGS from LOW LATITUDES; or, the Journal of the Hon. Impulsia Gushing ton. Edited by LORD DUFFERIN. With 24 Plates.4to. 21 s.

LITTLE ARTHUR'S HISTORY OF ENGLAND. By LADT CaLLCOTT. New and Cheaper Edition, continued to 1872. With Woodcuts. Fcap. 8vo. 1s. $6 d$.

LIVINGSTONE'S (DR.) Popular Account of Missionary Travels and Researches in South Africa. Illustrations. Post 8vo. $6 s$.

Narrative of an Expedition to the Zambezi and its Tributaries, with the Discovery of the Lakes Shirwa and Nyassa. Map and Illustrations. 8vo. 21s.

Last Journals in Central Africa, from 1865 to his Death. Continued by a Narrative of his last moments and sufferings. By Rev. Horace Waller. Maps and Illustrations. 2 Vols.
8vo. 28s.

LIVONIAN TALES. By the Author of "Letters from the Baltic." Post 8vo. 2s.

LOCH'S (H. B.) Personal Narrative of Events during Lord Elgin's Second Embassy to China. Second Edition. With Illustratious. Post 8vo. 9s. 
LOCKHART'S (J. G.) Ancient Spanish Ballads. Historical and Romantic. Translated, with Notes. New Edition. With Portrait and Illustrations. Crown 8vo. $5 s$.

Life of Theodore Hook. Fcap. 8vo. 1s.

LONSDALE'S (BIsHOP) Life. With Selections from his Writings. By E. B. Denison. With Portrait. Crown 8vo. 10s, $6 d$.

LOUDON'S (MRs.) Gardening for Ladies. With Directions and Calendar of Operations for Every Month. Eighth Edition. Woodcuts. Fcap. 8 vo. 3s. $6 d$.

LUCKNOW: A Lady's Diary of the Siege. Frap. 8vo. 4s.6d.

LYELL'S (Sir Charles) Principles of Geology; or, the Modern Changes of the Earth and its Inhahitants considered as illustrative of Geology. Eleventh Edition. With Illustrations. 2 Vols. 8vo. 32s. - Student's Elements of Geology. Second Edition. With Table of British Fossils and 600 Illustrations. Post 8vo. $9 s$.

Geological Evidences of the Antiquity of Man, including an Outline of Glacial Post-Tertiary Geology, and Remarks on the Origin of Species. Fourth Edition. Illustrations. 8vo. 14s.

(K. M.) Geographical Handbook of Ferns. With Tables to show their Distribution. Post 8 vo. $7 s .6 d$.

LYTTELTON'S (LoRD) Ephemera. 2 Vols. Post 8vo. 19s. $6 \mathrm{~d}$.

LYTTON'S (LORD) Memoir of Julian Fane. With Portrait. Post 8 vo. $5 s$.

MICLINTOCK'S (SIR L.) Narrative of the Discovery of the Fate of Sir John Franklin and his Companions in the Arctic Seas. Third Edition. With Illustrations. Post 8vo. 7s, 6d.

MACDOUGALL'S (Cou.) Modern Warfare as Influeneed by Modern Artillery. With Plans. Post 8vo. 12s.

MACGREGOR'S (J.) Rob Roy on the Jordan, Nile, Red Sea, Gennesareth, \&c. A Canoe Cruise in Palestine and Egypt and the Waters of Damascus. Clieaper Edition. With Map and 70 Illustrations. Crown 8 vo. $7 \varepsilon, 6 d$.

MACPHERSON'S (MAJOR) Services in India, while Political Agent at $\mathrm{G}$ walior during the Mutiny. Illustrations. 8vo. 12s.

MAETZNER'S ENGLISH GRAMMAR. A Methodical, Analytical, and Historical Treatise on the Orthography, Prosody, Inflections, and Syntax of the English Tongue. Trauslated from the German. By Clatr J. Grece, LL.D. 3 Vols. 8vo. $36 s$.

MAHON (LORD), see StanHope.

MAINE'S (Sir H. Sumner) Ancient Law: its Connection with the Early History of Society, and its Relation to Modern Ideas. Fifth Edition. 8vo. 12s.

Village Communities in the East and West. Second Edition. 8vo. 9s.

Early History of Institutions. 8vo. $12 s$.

MALCOLM'S (Sir JoHn) Sketches of Persia. Post 8vo. 3s. 6d.

MANSEL'S (DEAN) Limits of Religious Thought Examined. Fifth Edition. Post 8vo. 8s. 6 d.

- Letters, Lectures, and Papers, including the Phrontisterion, or Oxford in the XIXth Century. Edited by H. W. ChandLER, M.A. 8vo. $12 s$.

Gnostic Heresies of the First and Second Centuries. With a sketch of his life and character. By Lord Carnarvon. Edited by Canon LiGHTFOoT, 8vo, 10s. 6d.

MANUAL OF SCIENTIFIC ENQUIRY. For the Use of Travellers. Edited by Sir J. F. Herschel \& Rev. R. Main. Post 8vo. $3 s .6 d$. (Published by order of the Lords of the Aumiralty.) 
MARCO POLO. The Book of Ser Marco Polo, the Venetian. Concerning the Kingdoms and Marvels of the East. A new English Version. Illustrated by the light of Oriental Writers and Modern Travels. By Col. Henry Yule. New Edition. Maps and Illustrations. 2 Vols. Medium 8vo. $42 s$.

MARKHAM'S (Mrs.) History of England. From the First Invasion by the Romans to 1867 . Woodcuts. $12 \mathrm{mo} .3 s .6 d$.

History of France. From the Conquest by the Gauls to 1861. Woodcuts. $12 \mathrm{mo}$. $3 s .6 a$.

History of Germany. From the Invasion by Marius to 1867 . Woodcuts. $12 \mathrm{mo}$. $3 s .6 d$.

(Clements R.) Travels in Peru and India. Maps and Illustrations. 8 vo. $16 s$.

MARRYAT'S (JosEPH) History of Modern and Mediæval Fottery and Porcelain. With a Description of the Manufacture. Third Edition. Plates and Woodcuts. 8vo. 42s.

MARSH'S (G. P.) Student's Manual of the English Language. Post 8vo. 7s. $6 d$.

MATTHIAE'S GREEK GRAMMAR. Abridged by BroMFIELD, Revised by E. S. Crooke. 12mo. $4 s$.

MAUREL'S Character, Actions, and Writings of Wellington. Fcap. 8vo. 1s. 6d.

MAYNE'S (CAPT.) Four Years in British Columbia and Van. couver Island. Illustrations. 8vo. $16 s$.

MEADE'S (Hon. HerberT) Ride through the Disturbed Districts of New Zealand, with a Cruise among the Sonth Sea Islands. With Illustrations. Medium 8vo. $12 s$.

MELVILLE'S (Hermann) Marquesas and South Sea Islands. 2 Vols. Post 8 vo. $7 s$.

MEREDITH'S (Mrs. Charles) Notes and Sketches of New South Wales. Post 8vo. 2s,

MESSIAH (THE): The Life, Travels, Death, Resurrection, and Ascension of our Blessed Lord. By A Layman. Map. 8vo. 18s.

MILLINGTON'S (REv. T. S.) Signs and Wonders in the Land of Ham, or the Ten Plagues of Egypt, with Ancient and Modern Illustrations. Woodeuts. Post 8vo. $7 s .6 d$.

MILLS' (Rev. JoHs) Three Months' Residence at Nablus, with an Account of the Modern Samaritans. Illustrations. Post 8vo. 10s. $6 d$.

MILMAN'S (Dean) History of the Jews, from the earliest Period down to Modern Times. Fourth Edition. 3 Vols. Post 8 vo. $18 s$.

Early Christianity, from the Birth of Christ to the Abolition of Paganism in the Roman Empire. Fourth Edition. 3 Vols. Post 8vo. 18s.

Latin Christianity, including that of the Popes to the Pontificate of Nicholas V. Fourth Edition. 9 Vols. Post 8vo. 54s. Annals of St. Paul's Cathedral, from the Romans to the funeral of Wellington. Second Edition. Portrait and Illustrations. 8vo. $18 s$.

Character and Conduct of the Apostles considered as an Evidence of Christianity. 8vo. 10s. $6 d$.

Quinti Horatii Flacci Opera. With 100 Woodcuts. Small 8vo. $7 s .6 d$.

Life of Quintus Horatius Flaccus. With Illustrations. 8vo. $9 s$.

Poetical Works. The Fall of Jerusalem-Martyr of Antioch-Balshazzar-Tamor-Anne Boleyn-Fazio, \&c. With Portrait and Illustrations. 3 Vols. Feap. 8vo. 18s.

Fall of Jerusalem. Feap. 8vo. $1 s$.

(Сарт. E. A.) Wayside Cross. Post 8vo. $2 s$. 
MICHIE'S (Alexander) Siberian Overland Route from Peking to Petersburg. Maps and Illustrations. 8vo. 16s.

MODERN DOMESTIC COOKERY. Founded on Principles of Economy and Practical Knowledge. New Edition. Woodcuts. Fcap.8vo. $5 s$.

MONGREDIEN'S (Augustus) Trees and Shrubs for English Plantation. A Selection and Description of the most Ornamental which will flourish in the open air in our climate. With Classified Lists. With 30 Illustrations. 8vo. 16s.

MOORE \& JACKMAN on the Clematis as a Garden Flower. Descriptions of the Hardy Species and Varieties, with Directions for their Cultivation. 8vo. 10s.6d.

MOORE'S (Thomas) Life and Letters of Lord Byron. Cabinet Edition. With Plates. 6 Vols. Fcap. 8vo. 18s.; Popular Edition, witì Portraits. Royal 8vo. $7 s .6 d$.

MOSSMAN'S (SAMUEL) New Japan; the Land of the Rising Sun; its Annals and Progress during the past Twenty Years, recording the remarkable Progress of the Japanese in Westem Civilisation. With Map. 8vo. 15s.

MOTLEY'S (J. L.) History of the United Netherlands: from the Death of William the Silent to the Twelve Year's' Truce, 1609. Library Edition. Portraits. 4 Vols. 8vo. 60s. Cabinet Edition. 4 Vols. Pust 8vo. 6s. each.

Life and Death of John of Barneveld, Advocate of Holland. With a View of the Primary Causes and Movements of the 'Thirty Year's' War. Illustrations. 2 Vols. 8vo. 28s,

MOUHOT'S (HenrI) Siam, Cambojia, and Lao; a Narrative of Travels and Discoveries. Illustrations. 2 vols. 8vo.

MOZLEY'S (CANON) Treatise on Predestination. 8vo. $14 s$.

Primitive Doctrine of Baptismal Regeneration. 8vo. 7s.6d.

MUNDY'S (GeneraI) Pen and Pencil Sketches in India. Third Edition. Plates. Post 8vo. 7s.6d.

MUNRO'S (General) Life and Letters. By Rev. G. R. Gleig. Post 8vo。3s. $6 d$.

MIURCHISON'S (SIr Roperick) Russia in Europe and the Ural Mountains. With Coloured Maps, \&c. 2 Vols. 4to. 5l.5s.

Siluria ; or, a History of the Oldest Rocks containing Organic Remains. Fifth Edition. Map and Plates. 8vo. 18s. Memoirs. With Notices of his Contemporaries, and Rise and Progress of Palæozoic Geology. By Archibald Geikie. Portraits. 2 Vols. 8vo.

MURRAY'S RAILWAY READING. Containing:-

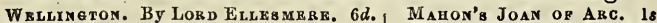

NIMROD ON THE CHASE, 18.

MUSIC AND DRESB. 18 .

MILMAY's FALL OF JERUSALEM. 18

MAHON'S "FORTX-FIVE." 38 .

MAHON's “FORTX-FIVE." 38.

DEBDs of Naval DaBing, $38.6 d$.

ThE HONEY BEE. 18.

Fs sOP's FABLEs. 2s. $6 d$.

NIMBOD ON THE TURF. 18, $6 d$.

ART OF DINING. 18. $6 d$.

HEAD's EMIGRANT. $28,6 d$.

Nimpod on the Road: 18.

CROKER ON THE GUILLOTIN 18.

HOLLWAX'g NORWAT. 28 ,

MaURel's Wellington. $18.6 d$.

CAMPBELL's LIFE OF BACON. 2s. $6 d$.

The Flowr a Garden. 18.

TAYLOR's NOTB FROM LIFE. 28 .

REJECTRD ADDRESBRs. 18 .

PhNN's Hints on ANGLing, 18.

MUSTERS' (CAPT.) Patagonians; a Year's Wanderings over Untrodden Ground from the Straits of Magellan to the Rio Negro. 2nd Edition. Illustrations. Post 8vo. 7s.6d.

NAPIER'S (Sir Chas.) Life, Journals, and Letters. Second Edition. Portraits. 4 Vols. Post 8vo. 48s. (SIr Wm.) Life and Letters. Portraits. 2 Vols. Crown 8vo. 28s.

English Battles and Sieges of the Peninsular Wrar. Fourth Edition. Portrait. Post 8vo. 9s. 
NAPOLEON AT FONTAINEBLEAU AND ELBA. A Journal of Occurrences and Notes of Conversations. By Sir NeIL CampbelL, C.B. With a Memoir. By Rev. A. N. C. Maclachlan, M.A. Portrait. $8 v 0.15 s$.

NASMYTH AND CARPENTER. The Moon. Considered as a Planet, a World, and a Satellite. With Illustrations from Drawings made with the aid of Powerful Telescopes, Woodcuts, \&c. Second Edition. 4to. 30 s.

NAUTICAL ALMANAC (The). (By Authority.) 2s. 6d。 d

NAVY LIST. (Monthly and Quarterly.) Post 8vo.

NEW TESTAMENT. With Short Explanatory Commentary. By Archdeacon Churton, M.A., and Archdeacon Basil Jones, M.A. With 110 authentic Views, \&c. 2 Vols. Crown 8vo 21s. bound.

NEWTH'S (SAMUEL) First Book of Natural Philosophy ; an Introduction to the Study of Staties, Dynamies, Hydrostatics, Optics, and Acoustics, with numerous Examples. Small 8vo. 3s. 6d.

Elements of Mechanics, including Hydrostatics, with numerous Examples. Fifth Edition. Small 8vo. 8s. 6d. Cloth.

Mathematical Examinations. A Graduated Series of Elementary Examples in Arithmetic, Algebra, Lngarithms, Trigonometry, and Mechanics. Third Edition. Small 8vo. 8s. 6d. each.

NICHOLLS' (Sir GEoRGE) History of the English, Irish and Scotch Poor Laws. 4 Vols. 8vo.

NICOLAS' (SIR HARRIs) Historic Peerage of England. Exhibiting the Origin, Descent, and Present State of every Title of Peerage which has existed in this Country since the Conquest. By William CourthoPe. 8 vo. 30 s.

NIMROD, On the Chace-Turf-and Road. With Portrait and Plates. Crown 8vo. 5s. Or with Coloured Plates, $7 s .6 d$.

NORDHOFF'S (Chas.) Communistic Societies of the United States; inclnding Detailed Accounts of the Shakers, The Amana, Oneida, Bethell, Aurora, Icarian and other existing Societies; witl Particulars of their Religious Creeds, Industries, and Present Condition. With 40 Illnstrations. 8vo. 15s.

OLD LONDON; Papers read at the Archæological Institute. By various Anthors. 8vo. $12 s$.

ORMATHWAITE'S (LorD) Astronomy and Geology-Darwin and Buckle-Progress and Civilisation. Crown 8vo. 6s.

OWEN'S (Lievt.-Cor.) Principles and Practice of Modern Artillery, including Artillery Material, Gunnery, and Organisation and Use of Artillery in Warfare. Second Edition. With Illustrations. 8vo. 15s.

OXENHAM'S (REv. W.) English Notes for Latin Elegiacs ; designed for early Proficients in the Art of Latin Versification, with Prefatory Rules of Composition in Elegiac Metre. Fifth Edition. 12mo. 3s.6d.

PALGRAVE'S (K. H. I.) Local Taxation of Great Britain and Ireland. 8vo. 5s.

Notes on Banking in Great Britain and IreLAND, SWeden, Denmark, and HambUrG, with some Remarks on the amount of Bills in circulation, both Inland and Foreign. 8vo. $6 s$.

PALLISER'S (Mrs.) Brittany and its Byeways, its Inhabitants, and Antiquities. With Illustrations. Post 8vo. 12s.

Mottoes for Monuments, or Epitaphs selected for General Use and Study. With Illustrations. Crown 8vo. $7 s .6 d$.

PARIS' (Dr.) Philosophy in Sport made Science in Earnest; or, the First Principles of Natural Philosophy inculcated by aid of the Toys and Sports of Youth. Ninth Edition. Woodcuts. Post 8vo. 7s.6d.

PARKMAN'S (Francrs) Discovery of the Great West; or, The Valleys of the Mississippi and the Lakes of North America. An Historical Narrative. Map. 8vo. 10s.6d. 
PARKYNS' (NANSField) Three Years' Residence in Abyssinia: with Travels in that Country. Second Edition, with Illustrations. Post 8vo. 7s.6d.

PEEK PRIZE ESSAYS. The Maintenance of the Church of England as an Established Church. By Rev. Charles Hole-Rev. R. Watson Dixon -and Rev. Julius Lloyd. 8vo. 10s.6d.

PEEL'S (Srr Robert) Memoirs. 2 Vols. Post 8vo. 15e.

PENN'S (RICHARD) Maxims and Hints for an Angler and Chessplayer. Woodcuts. Fcap. 8vo. $1 s$.

PERCY'S (Јон, M.D.) Metallurgy. Vol. I., Part 1. Fuel, Wood, Peat, Coal, Charcoal, Coke, Refractory Materials, Fire-Clays, \&c. Second Edition. With Illustrations. 8vo. 24s.

Vol. I., Part 2. Copper, Zinc, Brass. Second Edition. With Illustrations. 8vo. (In the Fress.) Vol. II. Iron and Steel. New Edition. With Illustrations. 8vo. (In Preparation.) Vol. III. Lead, including Desilverization and Cupellation. With Illustrations. 8vo. 30s.

Vols. IV. and V. Gold, Silver, and Mercury, Platinum, Tin, Nickel, Cobalt, Antimony, Bismuth, Arsenic, and other Metals. With Illustrations. 8vo.

PERSIA'S (SHAH of) Diary during his Tour through Kiurope in 1873. Translated from the Original. By J. W. RedHouse. With Portrait and Coloured Title. Crown 8vo. $12 s$.

PHILLIPS' (Јону) Memoirs of William Smith. 8vo. 7s.6d.

Geology of Yorkshire, The Coast, and Limestone District. Plates。 4to.

Rivers, Mountains, and Sea Coast of Yorkshire. With Essays on the Climate, Scenery, and Ancient Inhabitants. Second Edition, Plates. 8v0. 15s.

(SANuEL) Literary Essays from "The Times." With Portrait. 2 Vols. Fcap. 8vo. $7 s$.

PICK'S (Dr.) Popular Etymological Dictionary of the French Language. 8vo. $7 s .6 d$.

POPE'S (ALEXANDER) Works. With Introductions and Notes, by Rev. Whitwell ElwiN. Vols. I., II., VI., VII., VIII. With Portraits. 8vo. 10s, 6d. each.

PORTER'S (Rev. J. L.) Damascus, Palmyra, and Lebanon. With Travels among the Giant Cities of Bashan and the Hauran. New Edition. Map and Woodcuts. Post 8vo. $7 s .6 \alpha$.

PRAYER-BOOK (IlludTrated), with Borders, Initials, Vignettes, \&c. Edited, with Notes, by Rev. Thos. James. Medium 8vo. 18s. cloth; 31s. 6d. calf; 36s. morocco.

PRINCESS CHARLO'TTE OF WALES. A Brief Memoir. With Selections from her Correspondence and other unpublished Papers. By LadY Rose Weigall. With Portrait. 8 vo. $8 s, 6 d$.

PUSS IN BOOTS. With 12 Illustrations. By Otto Syeckter. $16 \mathrm{mo}$. 1s. $6 d$. Or coloured, $2 s .6 d$.

PRINCIPLES AT STAKE. Essays on Church Questions of the Day. 8vo. 12s. Contents :-

Ritualism and Uniformity.-Benjamin Shaw.

The Episcopate.-Bishop of Bath and Wells.

The Priesthood.-Dean of Canterbury.

National Education.-Rev. Alexander R. Grant.

Doctrine of the Eucharist.-Rev. G.

H. Sumuer.

Scripture and Ritual.-Canon Bernard. Church in South Africa. - Arthur Mills.

Schismatical Tendency of Ritualism. - Rev. Dr. Salmon.

Revisions of the Liturgy.-Rev. W.G. Humphry.

Parties and Party Spirit.-Dean of Chester. 
PRIVY COUNCIL JUDGMENTS in Ecclesiastical Cases relating to Doctrine and Discipline. With Historical Introduction, by G.C. Brodkick and W. H. Fie MIANtle. 8vo. 10s. $6 d$.

QUARTERLY REVIEW ('Tне). 8vo. $6 s$.

RAMBLES in the Syrian Deserts. Post 8vo. 10s. 6d.

RANKE'S (LEOPOLD) History of the Popes of Rome during the 16th and 17th Centuries. Translated from the German by SARAH A Ustin. Third Edition. 3 Vols. 8vo. 30s.

RASSAM'S (HoRMuZD) Narrative of the British Mission to Abyssinia. With Notices of the Countries Traversed from Massowah to Magdala. Illustrations. 2 Vols. 8 vo. 28 s.

RAWLINSON'S (CANON) Herodotus. A New English Version. Edited with Notes and Essays. Third Edition. Maps and Woodcut. 4 Vols. 8vo.

Five Great Monarchies of Chaldæa, Assyria, Media, Babylonia, and Persia. Third Eaition. With Maps and Mllustrations. 3 Vols. 8 vo. 42 s.

(Srr Henry) England and Russia in the East; a Series of Papers on the Pulitical and Geographical Condition of Central Asia. Map. 8vo.

REED'S (E. J.) Shipbuilding in Iron and Steel; a Practical Treatise, giving full details of Construction, Processes of Manufacture, and Building Arrangements. With 5 Plans and 250 Woodcuts. 8vo. 30 s. Iron-Clad Ships; their Qualities, Performances, and Cost. With Chapters on Turret Ships, Iron-Clad Rams, \&c. With Illustrations. 8vo. $12 s$.

REJEC'TED ADDRESSES (The). By James and Horace Smrth. New Edition. Woodcuts. Post 8vo. 3s. 6d.; or Popular Edition, Fcap. 8vo. $1 s$.

RENNIE'S (D. F.) British Arms in Peking, 1860. Post 8vo. 12s. Narrative of the British Embassy in China. Illustrations. 2 Vols. Post 8 vo. $24 s$.

Story of Bhotan and the Dooar War. Map and Wondeut. Post \&vo. $12 s$.

RESIDENCE IN BULGARIA; or, Notes on the Resources and Administration of Turkey, \&c. By S. G. B. ST. Clatr and Charies A. BropHy. 8vo. $12 s$.

REYNOLDS' (Sir Joshua) Life and Times. By C. R. Leshre, R.A. and TOM TAYLor. Portraits. 2 Vols. 8 vo.

RICARDO'S (DAvid) Political Works. With a Notice of his Life and Writings. By J. R. M'Culloch. New Edition. 8vo. $16 s$.

RIPA'S (FAtheR) Thirteen Years' Residence at the Court of Peking. Post 8vo. $2 s$.

ROBERTSON'S (CANON) History of the Christian Church, from the Apostolic Age to the Reformation, 1517. Library Edition. 4 Vols. 8vo. Cabinet Edition. 8 Vols. Post 8vo. 6s, each.

ROME. See LIDDELL and Suith.

ROWLAND'S (D A VID) Manual of the English Constitution. Its Rise, Growth, and Present State. Post 8vo. 10s.6d.

Laws of Nature the Foundation of Morals. Post 8vo. 6 s.

ROBSON'S (E. R.) SCHOOT, ARCHITECTURE. Being Practical Remarks on the Planning, Designing, Building, and Furruishing of School-holnes. With 300 Illustrations of School-buildings in all Parts of the World, drawn to scale. Medium 8vo. 31s.6d.

RUNDELL'S (Mrs.) Modern Domestic Cookery. Fcap. 8vo. 5s. 
RUXTON'S (GEoRae F.) Travels in Mexico; with Adventures among the Wild Tribes and Animals of the Prairies and Rocky Mountains. Post 8 vo. $3 s .6 d$.

ROBINSON'S (Rev. Dr.) Biblical Researches in Palestine and the Adjacent Regions, 1838-52. Third Edition. Maps. 3 Vols. 8vo. 42s. $10 s, 6 d$. (Wri.) Alpine Flowers for English Gardens. New
Edition. With 70 Illustrations. Crown 8vo. Wild Garden; or, our Groves and Shrubberies made beautiful by the Naturalization of Hardy Exotic Plants. With Frontispiece. Small 8vo. $6 s$.

Sub-Tropical Garden ; or, Beauty of Form in the Flower Garden. With Illustrations. Small Svo. 7s. $6 d$.

SALE'S (SIR ROBERT) Brigade in Affghanistan. With an Account of the Defence of Jellalabad. By Rev. G. R. GLeig: Post 8vo. $2 s$.

SCHLIEMANN'S (Dr. Henry) Troy and Its Remains, A Narrative of Researches and Discoveries made on the Site of Ilium, and in the Trojan Plain. Edited by Philip Sirrth, B.A. With Maps, Plans, Views, and 500 Illustrations of Objects of Antiquity, \&c. Medium 8vo.

SCOTT'S (Sir G. G.) Secular and Domestic Architecture, Present and Future. 8vo. 9s.

(DEAN) University Sermons. Post 8vo. 8s. 6d.

SHADOWS OF A SICK ROOM. Second Edition. With a Preface by Canon LidDon. 16mo. is $6 d$.

SCROPE'S (G. P.) Geology and Extinct Volcanoes of Central France. Illustrations. Medium 8vo. 30s.

SHAW'S (T. B.) Manual of English Literature. Post 8vo. 7s. 6d.

- Specimens of English Literature. Selected from the Chief Writers. Post 8vo, 7s. 6d.

(RoBerT) Visit to High Tartary, Yarkand, and Kashgar (formerly Chinese Tartary), and Return Journey over the Karakorum Pass. With Map and Illustrations. 8vo. 16s.

SHIRLEY'S (Every P.) Deer and Deer Parks ; or some Account of English Parks, with Notes on the Management of Deer. Illustrations. 4to. 21s.

SIERRA LEONE; Described in Letters to Friends at Home. By A Ladr. Post 8vo. 3s. $6 c$.

SINCLAIR'S (ArchdeacoN) Old Times and Distant Places. A Series of Sketches. Crown 8 vo.

SMILES' (SAMUEL) Lives of British Engineers ; from the Earliest Period to the death of the Stephensons. With Portraits and Illustrations. Cabinet Edition. 5 Vols. Crown 8vo. 7s.6d. each. Lives of George and Robert Stephenson. Library Edition. With Portraits and Illustrations. Medium 8vo. $21 s$.

Lives of Boulton and Watt. Library Edition. With Portraits and Illustrations. Medium 8vo. 21s.

- Self-Help. With Illustrations of Conduct and Perseverance. Post 8vo. 6s. Or in French, 5s.

Character. A Companion Volume to "Self-Henp." Post 8 vo. 6s.

- Industrial Biography: Iron-Workers and Tool-Nakers. Post 8vo. 6s.

Boy's Voyage round the World; including a Residence in Victoria, and a Journey by Rail across North America. With Illustrations. Post 8vo. 6s. 
SMITTH'S (Dr. Wr.) Dictionary of the Bible; its Antiquities, Biography, Geography, and Natural History. Illustrations. 3 Vols. 8 г0. $105 s$.

Christian Antiquities. Comprising the History, Institutions, and Antiquities of the Christian Church. 2 Vols. 8vo. Vol. I.

(Nearly ready.

Biography and Doctrines; from the Times of the Apostles to the Age of Charlemagne. $8 \mathrm{v}$.

Concise Bible Dictionary. With 300 Illustrations. Medium 8vo. 21s.

Smaller Bible Dictionary. With Illustrations. Post 8vo. $7 s .6 d$.

- Atlas of Ancient Geography-Biblical and Classical. (5 Parts.) Folio. 21s, each.

Greek and Roman Antiquities. With 500 Illustrations. Medium 8vo. 28s.

600 Illustrations. 3 Vols. Medium 8vo. $4 l .4 s$.

lllustrations. Medium 8vo. 56s.

Geography. 2 Vols. With 500

Classical Dictionary of Mythology, Biography, and Geography. 1 Vol. With 750 Woodcuts. 8vo. 18 s.

- Smaller Classical Dictionary. With 200 Woodcuts. Crown 8vo. 7s.6d.

Greek and Roman Antiquities. With 200 Wood. cuts. Crown 8 vo. $7 s .6 d$.

- Latin-English Dictionary. With Tables of the Roman

Calendar, Measures, Weights, and Money, Medinm 8vo. $21 s$.

Smaller Latin-English Dictionary. 12mo. $7 s .6 d$.

English-Latin Dictionary. Medium 8vo. $21 s$.

- Smaller English-Latin Dictionary. 12mo. $7 s .6 d$.

School Manual of English Grammar, with Copious

Exercises. Post 8vo. 3s. 6d.

- Primary English Grammar. 16mo. $1 s$. History of Britain. $12 \mathrm{mo} .2 s .6 d$.

French Principia. Part I. A Grammar, Delectus, Exercises, and Vocabularies. $12 \mathrm{mo}$. is. $6 d$.

- Principia Latina-Part I. A Grammar, Delectus, and Exercise Book, with Vocabularies. With the ACCIDENCE arranged for the "Public School Primer." 12mo. 3s.6d.

Part II. A Reading-book of Mythology, Geography, Roman Antiquities, and History. With Notes and Dictionary. $12 \mathrm{mo}$. $3 s .6 d$.

Part III. A Latin Poetry Book. Hexameters and Pentameters; Eclog. Uvidianæ; Latin Prosody. $12 \mathrm{mo}$. $3 s, 6 d$.

Part IV. Latin Prose Composition. Rules of Syntax, with Examples, Explanations of Synonyms, and Exercises on the Syntax. $12 \mathrm{mo}$. $3 s .6 d$.

Part V. Short Tales and Anecdotes tor Translation into Latin. $12 \mathrm{mo} .3 s$.

Latin-English Vocabulary and First Latin-English Dictionary for Phæ lrus, Cornelius Nepos, and Cæsar. 12mo. 3s. $6 d$.

- Student's Latin Grammar. Post 8vo. 6s.

Smaller Latin Grammar. 12mo. $3 s .6 d$. 
SMIITH's (Dr. Wм.) Tacitus, Germania, Agricola, \&c. With English Notes. 12mo. 3s. $6 d$.

Initia Græca, Part I. A Grammar, Delectus, and Exercise-book. With Vocabularies. $12 \mathrm{mo}$. $3 s .6 d$.

Initia Græca, Part II. A Reading Book. Containing Short Tales, Anecdotes, Fables, Mythology, and Grecian History. 12mo. 3s. $6 d$.

- Initia Græca, Part III. Greek Prose Composition. Containing the Rules of Syntax, with copious Examples and Exercises. 12mo. $3 s .6 d$.

- Student's Greek Grammar. By Professor Curtius, Post 8vo. 6s.

- Smaller Greek Grammar. 12mo. 3s. $6 d$.

Greek Accidence. Extracted from the above work. $12 \mathrm{mo} .2 s .6 d$.

Plato. The Apology of Socratea, the Crito, and Part of the Phædo; with Notes in English from Stallbaum and Schleiermacher's Introductions. $12 \mathrm{mo} .3 s .6 d$.

$3 s .6 d$.

Smaller Scripture History. Woodeuts. $16 \mathrm{mo.}$

Ancient History. Wondents. 16mo. 3s. $6 \mathrm{~d}$.

Geography. Woodcuts. $16 \mathrm{mo}$. 3s. $6 i$.

Rome. Woodcuts. $16 \mathrm{mo}$. 3s. $6 d$.

Greece. Woodcuts. $16 \mathrm{mo}$. $3 s .6 d$.

Classical Mythology. With Translations from

the Poets. Woodcuts. 16mo. 3s.6 .

- History of England. Woodcuts. 16mo. 3s. $6 d$.

English Literature. 16mo. 3s. $6 d$.

Specimens of English Literature. 16mo. 3s. $6 d$.

- (Phrmip) History of the Ancient World, from the Greation to the Fall of the Roman Empire, A.D. 455. Fourth Edition. 3 Vols. 8 vo. 31s. $6 d$.

(Rev. A. C.) Nile and its Banks. Woodcuts. 2 Vuls. Post 8vo. 18s.

SiMMIONS' (CAPT.) Constitution and Practice of Cour's-Martial ; with a Summary of the Law of Evidence, and some Notice of the Criminal Law of England with reference to the Trial of Civil Offences. Sixth Edition. 8vo. 15s.

STANLEY'S (DeAN) Sinai and Palestine, in connexion with their History. 20th Thousand. Map. 8vo. $14 s$.

Bible in the Holy Land; Extracted from the above Work. Second Edition. Woodcuts. Fcap. 8vo. $2 s 6 d$.

Wistory of the Eastern Church. Fourth Edition. Plans. 8vo. $12 s$.

8vo. $24 s$. Jewish Church. Fifth Edition. Church of Scotland. 8vo. 7s. $6 d$.

Memorials of Canterbury Cathedral. Fifth Edition. Woodcuts. Post 8vo, 7s. 6d.

Westminster Abbey. Third Edition.

With Illustrations. 8 ro. $21 s$.

Sermons during a Tour in the East. 8 vo. $9 s$.

Post 8vo. 7s. $6 d$. on Evangelical and Apostolical Teaching.

Addresses and Charges of the late Bishop Stanley.

With Memoir. 8vo, $10 s .6 d$. 
STUDENT'S OLD TESTAMENT HISTORY ; from the Creation to the Return of the Jews from Captivity. Maps and Woodcuts. Post 8 vo. $7 s .6 d$.

NEW TESTAMENT HISTORY. With an Introduction connecting the History of the Old and New Testaments. Maps and Woodents. Post 8vo. 7s, $6 d$.

ANCIENT HISTORY OF THE EAST; Egypt, Assyria, Babylonia, Media, Persia, Asia Minor, and Phœnicia. Py Philip Smith. Woodcuts. Post 8vo. 7s.6d.

Woodcuts. Post 8vo. 7s, $6 d$.

HISTORY OF GREECE ; from the Earliest Times to the Roman Conquest. By Wм. Smitr, D.C.L. Woodcuts. Crown 8vo. 7s. $6 d$.

* * Questions on the above Work, 12mo. $2 s$.

HISTORY OF ROME; from the Earliest Times to the Establishment of the Empire. By Dean Liduels. Woodcuts. Crown 8vo. $7 s, 6 d$.

GIBBON'S Decline and Fall of the Roman Empire.

Woodcuts. Post 8vo. 7s.6d.

HALLAM'S HISTORY OF EUROPE during the Middle Ages. Post $8 v o$. 7s. $6 d$.

HUME'S History of England from the Invasion of Julius Cæsar to the Revolution in 1638. Continued down to 1863. Woodcuts. Post 8vo. 7s. $6 d$.

** Questions on the above Work. 12mo. 2s.

HALLAM'S HISTORY OF ENGLAND ; from the Accession of Henry VII. to the Death of George II. Post 8vo, $7 s .6 d$. ENGLISH LANGUAGH. By Geo. P. Marsh. Post 8vo. 7s. $6 d$.

Post 8vo. 7s. $6 d$. LITERATURE. By T. B. Shaw, M.A. SPECIMENS of English Literature from the Chief Writers. By T. B. SнAw, Post 8vo. 7s. $6 d$.

HISTORY OF FRANCE; from the Earliest Times to the Establishment of the Second Empire, 1852. By REv. H. W. Jervis. Woodcuts. Post 8vo. 7s.6d.

- MODERN GEOGRAPHY ; Mathematical, Physical, and Descriptive. By Rev. W. L. Bevan. Woodcuts. Post 8vo. 7s, 6d. MORAL PHILOSOPHY. By William Fleming,

D.D. Post 8vo. 7s. $6 d$.

BLACKSTONE'S Commentaries on the Laws of England. By R. MALCOLM Kerr, LL.D. Post 8vo. 7s.6d.

ECCLESIAS'IICAI, HISTORY. A History of the Christian Church from its Foundation to the Eve of the Protestant Reformation. By Philip Sмiтh, B.A. Post 8vo. $7 s 6 d$.

SPALDING'S (CAptain) Tale of Frithiof. Translated from the Swedish of Esias Tegner. Post 8vo. 7s. $6 d$.

STEPHEN'S (REv. W. R.) Life and Times of St. Chrysostom. With Portrait. 8vo. 15s.

ST. JOHN'S (Charles) Wild Sports and Natural History of the Highlands. Post 8vo. 3s. $6 d$.

(BAy LE) Adventures in the Libyan Desert. Post $\delta$ vo. $2 s$.

STORIES FOR DARLINGS. With Illustrations. $16 \mathrm{mo}$. $5 s$.

S'TREET'S (G. E.) Gothic Architecture in Spain. From Personal Observations made during several Journeys. Second Edition. With Illustrations. Royal 8vo. 30s.

Gothic Architecture in Italy, chiefly in Brick and Marble. With Notes of Tours in the North of Italy. Second Edition. With 60 Illustrations. Rnyal Svo. $26 s$. 
STANHOPE'S (EARL) England during the Reign of Queen Anne, 1701-13. Library Edition. 8vo. 16s. Cabinet Edition. Portrait. 2 Vols. Post 8vo. 10s.

from the Peace of Utrecht to the Peace of Versailles, 1713-83. Library Edition. 7 vols. 8vo. 93s. Cabiret Edition, 7 vols. Post 8vo. 5s. each.

British India, from its Origin to 1783. 8 vo. $3 s .6 d$. History of "Forty-Five." Post 8vo. $3 s$.

Spain under Charles the Second. Post 8vo. 6s. $6 d$. Historical and Critical Essays. Post 8vo, 3s. 6d.

Life of Belisarius. Post 8vo. 10s. $6 d$.

Condé. Post 8vo. 3s. $6 d$.

William Pitt. Portraits. 4 Vols. 8vo. $24 s$. Miscellanies. 2 Vols. Post 8vo. $13 s$.

Story of Joan of Arc. Fcap. 8vo. 1s.

Addresses Delivered on Various Gccasions. $16 \mathrm{mo} .1 \mathrm{~s}$.

STYFFE'S (KNutr) Strength of Iron and Steel. Plates. 8vo. $12 s$.

SOMERVILLE'S (MARx) Physical Geography. Sixth Edition, Portrait. Post 8vo. 9s.

Connexion of the Physical Sciences. Ninth

Edition. Portrait. Post 8vo. 9s.

Molecular and Microscopic Science. Illustrations. 2 Vols. Post 8 vo. $21 s$.

Personal Recollections from Early Life to old Age. With Selections from her Correspondence. Fourth Edition. Portrait. Cromn 8vo. 12s.

SOUTHEY'S (RoBert) Book of the Church. Post 8vo. 7s.6d. Lives of Bunyan and Cromwell. Post 8vo. 2s.

SWAINSON'S (Canon) Nicene and Apostles' Creeds; 'Their Literary History; together with some Account of "The Creed of St. Athanasius." 8vo.

SYBEL'S (VoN) History of Europe during the French Revolution, $1789-1795$. 4 Vols. 8vo. $48 s$.

SYMONUS' (REv. W.) Records of the Rocks; or Notes on the Geology, Natural History, and Antiquities of North and South Wales, Siluria, Devon, avd Cornwall. With Illustrations. Crown 8vo. $12 s$.

TAYLOR'S (Srr Henry) Notes from Life. Feap. 8vo. $2 s$.

THIELMAN'S (BARoN) Journey through the Caucasus to Tabreez, Kurdistan, down the Tigris and Euphrates to Nineveh and Rabylon, and across the Desert to Palmyra. Translated by Cris. HENEAGE. 2 Vols. Post 8 vo.

'THOMS' (W. J.) Longevity of Man; its Facts and its Fiction. Including Observations on the more Remarkable Instances. Post 8vo. 10s. 6r.

THOMSON'S (ARCHBISHOP) Lincoln's Inn Sermons. 8vo. 10s. $6 \mathrm{~d}$.

- Life in the Light of God's Word. Post 8vo. $5 s$.

TOCQUEVILLE's State of Society in France before the Revolution, 1789, and on the Causes which led to that Event. Translated by Henry REEVE. 2nd Edition. 8vo. $12 s$.

TOMLINSON (Chanles); The Sonnet; Its Origin, Structure, and Place in Poetry. With translations from Dante, Petrarch, \&c. Post 8vo. $9 s$.

TOZER'S (REv. H. F.) Highlands of Turkey, with Visits to Mounts Ida, Athos, Olympus, und Pelion. 2 Vols. Crown 8vo. 24s.

- Lectures on the Geography of Greece. Map. Post 8vo. $9 s$. 
TRISTRAM'S (CANoN) Great Sahara. Illustrations. Crown 8vo. 15s. Land of Moab ; Travels and Discoveries on the East Side of the Dead Sea and the Jordan. Second Edition. Illustrations. Crown 8vo. 15s.

TWISLETON (EDWARD). The Tongue not Essential to Speech, with Illustrations of the Power of Speech in the case of the African Confessors. Post 8 vo. $6 s$.

'TWISS' (HoRACE) Life of Lord Eldon. 2 Vols. Post 8ro. 21s.

TYLOR'S (E. B.) Early History of Mankind, and Development of Civilization. Second Edition. 8vo. $12 s$.

- Primitive Culture; the Development of Mythologs, Philosoply, Religion, Art, and Custom. Second Edition. 2 Vols. 8 vo. $24 s$.

VAMBERY'S (ARMinius) 'Travels from Teheran across the Turkoman Desert on the Eastern Shore of the Caspian. Illustrations. 8vo. $21 s$.

VAN LENNEP'S (HENRx J.) Travels in Asia Minor. With Illustrations of Biblical Literature, and Archæology. With Woodcuts, 2 Vols. Post 8 vo. 24s.

WELLINGTON'S Despatches during his Campaigns in India, Denmark, Portugal, Spain, the Low Countries, and France. Edited by Colonel Gurwood. 8 Vols. 8vo. 20s. each.

Supplementary Despatches, relating to India, Ireland, Denmark, Spanisl America, Spain, Portugal, France, Congress of Vienna, Waterloo and Paris. Edited by his Son. 14 Vols. 8 vo. 20s. each. ** * An Index. 8ro. 20s. Civil and Political Correspondence. Edited by his Son. Vols. I. to V. 8vo. 20s. each. Despatches (Selections from). 8ro. $18 s$. Speeches in Parliament. 2 Vols. 8vo. $42 s$.

WHEELER's (G.) Choice of a Dwelling; a Practical Handbook of Useful Information on Building a House. Third Edition. Plans. Post 8vo. $7 s, 6 d$.

WHITE'S (Henry) Massacre of St. Bartholomew. 8vo. $16 s$.

WHYMPER'S (EDWARD) Scrambles among the Alps. With the First A scent of the Matterhorn, and Notes on Glacial Phenomena. Second Edition. Illustrations. 8vo. 21s.

(Frederick) Travels and Adventures in Alaska. Illustrations. 8vo. $16 s$.

WILBERFORCE'S (Bishop) Essays on Various Subjects. 2 vols. 8 vo. $21 s$. 8vo. $6 s$.

WILKINSON'S (Sir J. G.) Popular Account of the Ancient Egyptians. With 500 Woodcuts. 2 Vols. Post 8 vo. $12 s$.

WOOD'S (CAPTAIN) Source of the Oxus. With the Geography of the Valley of the Oxus. By Col. Yule. Map. 8vo. 12s.

WORDS OF HUMAN WISDOM. Collected and Arranged by E. S. With a Preface by Canon Liddon, D.D. Fep. 8 vo. 3s. $6 d$.

WORDSWORTH'S (Bishop) Athens and Attica. Plates. 8vo. 5s. Greece. Pictorial, Descriptive, and Historical. With 600 Wooderits. Royal $8 \mathrm{vo}$.

YULE'S (Colones) Book of Mareo Polo. Illustrated by the Light of Oriental Writers and Modern Travels. With Maps and 80 Plates. 2 Vols. Medium 8vo. $42 s$.

ZINCKE'S (Rev. F. B.) Winter in the United States. Post 8vo. 10s. 6 .

BRADBURY, AGNEW, \& CO., FRINTERs, WHITEFRIARs. 
, 


